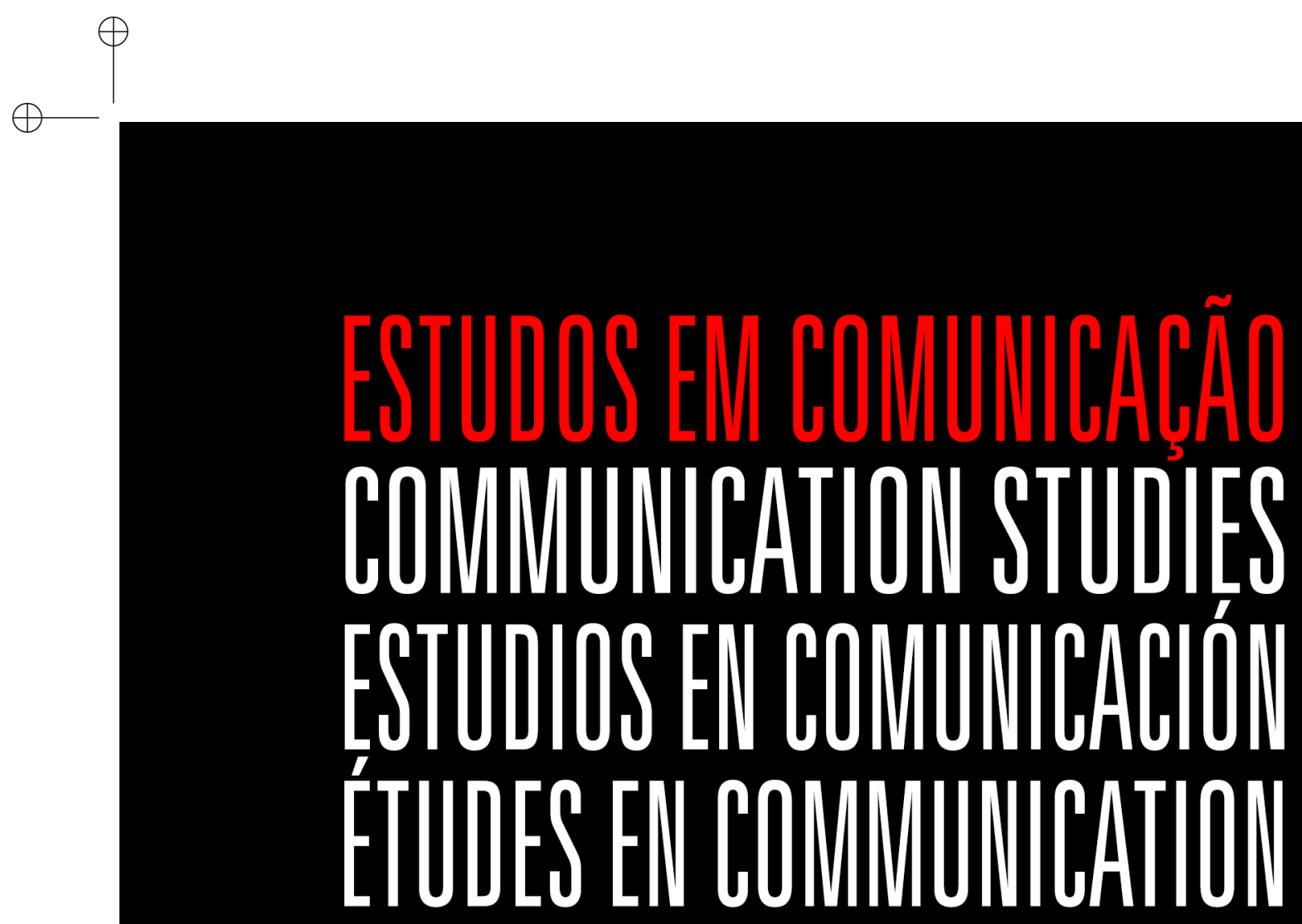
REVISTA . REVIEW . REVISTA . MAGAZIINE

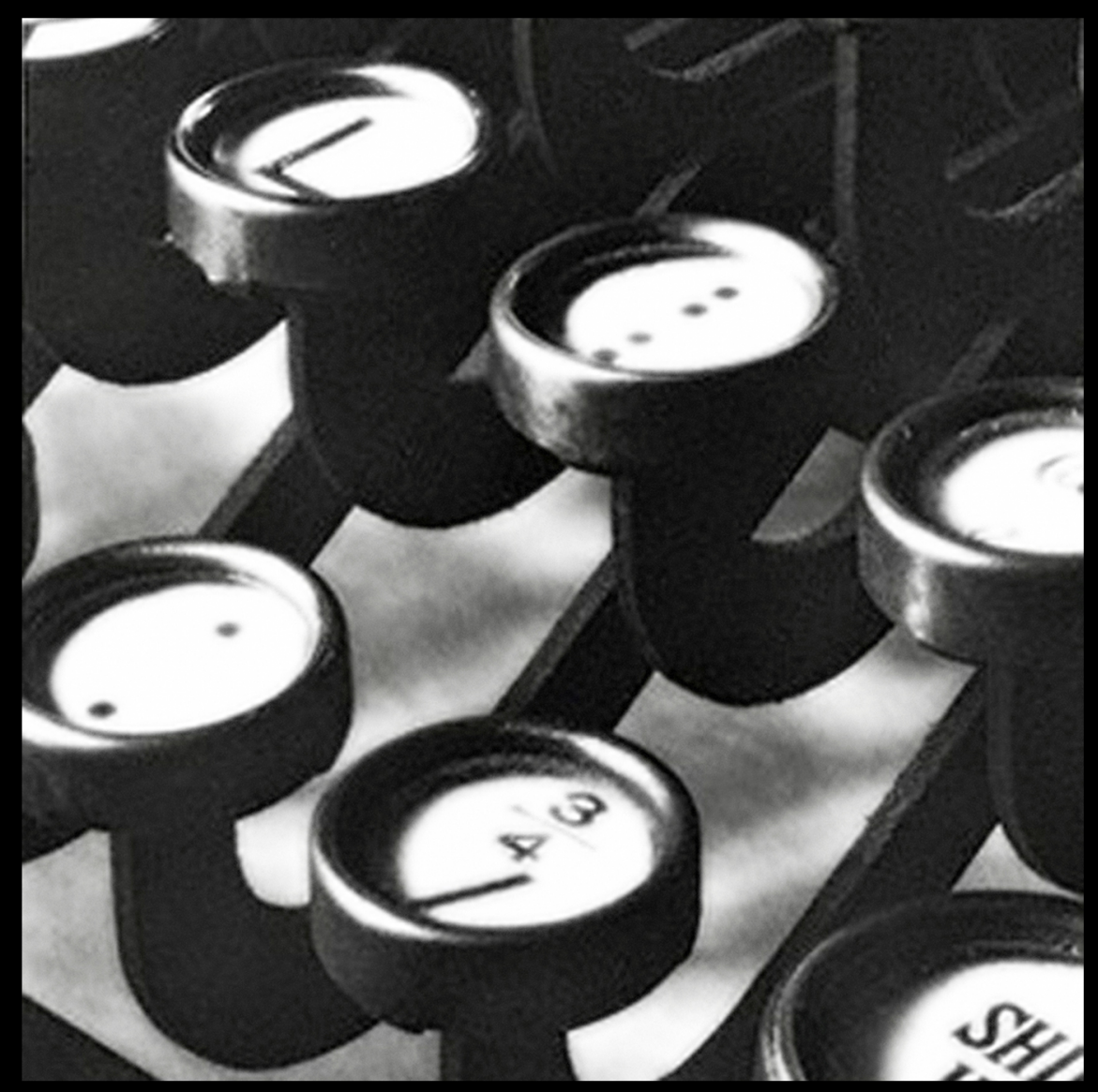


$\bigoplus$

$\bigoplus$

$\oplus$ 
EDITORS [EDITORES]

João Carlos Correia (Universidade da Beira Interior, Portugal)

Anabela Gradim (Universidade da Beira Interior, Portugal)

GUEST EDITORS [EDITORES CONVIDADOS]

Anabela Gradim (Universidade da Beira Interior, Portugal)

Catarina Moura (Universidade da Beira Interior, Portugal)

\section{INTERNATIONAL SCIENTIFIC BOARD [PAINEL CIENTÍFICO INTERNACIONAL]}

António Fidalgo (Universidade da Beira Interior, Portugal)

Afonso Albuquerque (Universidade Federal Fluminense, Brasil)

Alfredo Vizeu (Universidade Federal de Pernambuco, Brasil)

António Bento (Universidade da Beira Interior, Portugal)

Ana Serrano Telleria (Universidade da Beira Interior, Portugal)

Ana Catarina Pereira (Universidade da Beira Interior, Portugal)

Barbie Zelizer (University of Pennsylvania, USA)

Catarina Rodrigues (Universidade da Beira Interior, Portugal)

Catarina Moura (Universidade da Beira Interior, Portugal)

Catarina Moura (Universidade da Beira Interior, Portugal)

Cláudia Alvares (Universidade Lusófona de Humanidades e Tecnologias Escola de Comunica-

ção. Artes e Tecnologias da Informação, Portugal)

Colin Sparks (University of Westminster, United Kingdom)

Eduardo Camilo (Universidade da Beira Interior, Portugal)

Eduardo Meditsch (Universidade Federal de Santa Catarina, Brasil)

François Heinderyckx (Université Libre de Bruxelles, Belgique)

Elias Machado (Universidade Federal de Santa Catarina, Brasil)

Francisco Costa Pereira (Escola Superior de Comunicação Social, Portugal)

Gil Ferreira (Universidade Católica Portuguesa)

Hélder Prior (Universidade de Brasília, Brazil)

Helena Sousa (Universidade do Minho, Portugal)

Ivone Ferreira (Universidade da Beira Interior, Portugal)

Javier Díaz Noci (Universidad del País Vasco, Espanã)

Jean Marc-Ferry (Université Libre de Bruxelles, Institut d'Études Européennes, Belgique)

João Pissarra Esteves (Universidade Nova de Lisboa, Portugal)

João Canavilhas (Universidade da Beira Interior, Portugal)

Joaquim Paulo Serra (Universidade da Beira Interior, Portugal)

Jorge Pedro Sousa (Universidade Fernando Pessoa, Portugal)

José Bragança de Miranda (Universidade Lusófona; Universidade Nova de Lisboa, Portugal)

Liesbet van Zoonen (University of Amsterdam, Holanda)

Luís Costa Nogueira (Universidade da Beira Interior, Portugal)

Manuel Pinto (Universidade do Minho, Portugal)

Mark Deuze (Indiana University, USA)

Maria João Silveirinha (Universidade de Coimbra, Portugal)

Marisa Torres Silva (FCSH, CIMJ, Portugal) 
Mário Mesquita (Escola Superior de Comunicação Social de Lisboa, Portugal)

Marcos Palácios (Universidade Federal da Bahia, Brasil)

Martin Jay (University of California, Berkeley, USA)

Miguel Rodrigo Alsina (Universitat Pompeu Fabra, España)

Michael Gurevitch (University of Maryland, USA)

Nelson Traquina (Universidade Nova de Lisboa, Portugal)

Nico Carpentier (Vrije Universiteit Brussel -VUB- , Katholieke Universiteit Brussel - KUB)

Nathalie Zaccai - Reyners (Université Libre de Bruxelles, Belgique)

Paula Espírito Santo (Instituto Superior de Ciências Sociais e Políticas, Universidade Técnica

de Lisboa, Portugal)

Peter Dahlgren (Lunds Universitet, Sweden)

Pedro Coelho (SIC, Jornalista ; Investigador)

Ramón Salaverría (Universidad de Navarra, España)

Stephen K. White (University of Virgínia, EUA)

Rosental Calmon Alves (University of Texas, USA)

Steve Reese (University of Texas, USA)

Susan Buck-Morss (Cornell University)

Tito Cardoso e Cunha (Universidade da Beira Interior, Portugal)

Todd Gitlin (Columbia University, USA)

Xosé Lópes García (Universidad Santiago de Compostela, España)

\section{GRAPHICAL DIRECTOR [DIRECÇÃO GRÁFICA] \\ Catarina Moura \\ COLLABORATORS [COLABORADORES]}

Filomena Matos, Susana Costa, Cristina Lopes, António Tomé e Manuela Penafria

\section{CREDITS [FICHA TÉCNICA]}

(C) Estudos em Comunicação [Communication Studies]

LabCom.IFP - Comunicação, Filosofia e Humanidades

UBI - Universidade da Beira Interior

Universidade da Beira Interior - FAL/LabCom.IFP

Rua Marquês D’Ávila e Bolama

6201-001 Covilhã, Portugal

ISSN : 1646-4923

ISSN (suporte electrónico) : 1646-4974

DOI : $10.20287 / \mathrm{ec}$

DOI [ $\left.\mathrm{n}^{\circ} 21\right]: 10.20287 / \mathrm{ec} . \mathrm{n} 21$

Semestral periodicity [Periodicidade semestral]

Contacts [Contatos] : joao.correia@labcom.ubi.pt, anabela.gradim@labcom.ubi.pt

Call for papers opened on : January 21th, 2015

Manuscript Submission : November 3rd, 2015

Acceptance Notification : November 30th, 2015

Publication : December, 2015 


\section{Index [Índice]}

Sobre a autonomia relativa da Comunicação de Ciência por Diogo Silva da Cunha

Considerações sobre os desafios múltiplos da Ciência Aberta por Tiago Lima Quintanilha

$O$ cientista, o jornalista e o assessor.

Uma análise dos embates, dos limites e das possibilidades de construção de um possível diálogo

por Boanerges Balbino Lopes Filho \& Wedencley Alves

És o que podias ter sido? Sobre como os jovens contemporâneos são convocados ao inverossímil por Lina Raquel Marinho \& Lana Veras

A pesquisa em Ciências da Comunicação com o uso das novas mídias digitais por Paulo Eduardo Silva Lins Cajazeira

A hegemonia científica e o senso comum na internet: uma análise segundo a Epistemologia do Sul de Boaventura de Sousa Santos

por Cleber Femina \& Kênia Maia

Comunicação, Ideologia e Ciência: questões epistemológicas e metodológicas

por Rakel de Castro \& Heitor Costa Lima da Rocha 
La espiral del conocimiento en la redacción de artículos científicos por María del Rosario Demuner-Flores, Rosa María Nava Rogel \& Patricia Mercado-Salgado

Alinhamento estratégico:

o papel da informação na integração de propósito, processos e pessoas em Instituições no Brasil

por Antonio Rodrigues de Ândrade \& Aldo de Albuquerque Barreto 127

Likes para a ciência: divulgação científica e consumo de notícias na página I Fucking Love Science no Facebook por Talyta Singer

A faixa infanto-juvenil como público da ciência

e a ciência que lhes é proposta

por Carlos Alberto de Carvalho \& Luiza Lages de Souza Ramos

Exposições de Dinossauros em Portugal Comunicar Paleontologia, Métodos e Problemáticas por Simão Mateus

A Comunicação nas ciências interdisciplinares: o compromisso de um discurso - o caso da área da Saúde por Anabela Félix Mateus

O Acesso Aberto no Turismo:

Resultados preliminares por Cristina Marques Gomes

Carbon Dust na comunicação científica - potencialidades e perspetiva por Sofia M. Ferreira \& Fernando J. Correia

Comunicação da ciência e mobilização ou "quanto vale a água"?

por Adriana Bravin

Sistema de revisão por pares na ciência: o caso de revistas científicas do Brasil, da Espanha e do México por Cláudio N. N. Silva, Murilo A. A. Silveira \& Suzana P. M. Mueller 


\title{
Sobre a autonomia relativa da Comunicação de Ciência
}

\author{
Diogo Silva da Cunha \\ Centro de Filosofia das Ciências da Universidade de Lisboa \\ E-mail: cunhadiogo15@gmail.com
}

\begin{abstract}
Resumo
A expressão 'Comunicação de Ciência' permite delinear um campo disciplinar relativamente autónomo, no qual hoje se cruzam investigadores das ciências, investigadores da comunicação e dos $m e$ dia e também profissionais da comunicação social, particularmente jornalistas. A complexidade actual do campo sugere a existência de algumas tensões socioculturais e profissionais. Este trabalho oferece uma visão sinóptica, necessariamente fragmentária, da génese do campo

disciplinar da Comunicação de Ciência e da sua autonomização. Parte-se das intersecções entre história das ciências e história das técnicas de comunicação. $\mathrm{O}$ objectivo é o de fornecer uma estrutura de desenvolvimento de como a Comunicação de Ciência se tornou um campo disciplinar relativamente autónomo. $\mathrm{O}$ processo de formação disciplinar é pensado em três fases: emergência de novas práticas, institucionalização e reconhecimento.
\end{abstract}

Palavras-chave: Autonomia relativa; disciplinas; comunicação de ciência; circulação do conhecimento científico; jornalismo de ciência.

\begin{abstract}
Abstract: The expression 'Science Communication' allows us to set a relatively autonomous disciplinary field, in which today one may found researchers of sciences, researchers of communication and media as well as media professionals, particularly journalists. The current complexity of the field suggests the existence of some socio-cultural and professional tensions. This paper provides a synoptic view, necessarily frag-

nary field of Science Communication and of its autonomy. The starting point is the intersection between history of sciences and history of communication techniques. Our purpose is to give a developmental structure of how Science Communication came to be a disciplinary relatively autonomous field. The process of disciplinary formation is designed in three phases: the emergence of new practices, institutionalization and recognition.
\end{abstract} mentary, of the genesis of the discipli-

Estudos em Comunicação no 21, 1-12 
Keywords: Relative autonomy; disciplines; science communication; circulation of scientific knowledge; science journalism.

"Comment peut-on être Persan?" Montesquieu, Les lettres persanes, Lettre 30 (1721)

\title{
Introdução
}

\begin{abstract}
A expressão 'Comunicação de Ciência' permite delinear um campo disciplinar relativamente autónomo, um conjunto de relações de poder disciplinarmente instituídas e relativamente autónomas em relação a outros domínios disciplinares. Como todas as disciplinas, a Comunicação de Ciência tem uma identidade cognitiva, que descreve objectos, metodologias e teorias, uma identidade sociocultural, estrutura incorporada e incorporante dos símbolos cognitivos através de cursos, associações, conferências, revistas e livros, e uma identidade profissional, caracterizadora da relação trabalho-horáriosalário dos actores desse campo (Kuhn, 1962; Gingras, 1991; Turner, 2000; Stichweh, 2001; Weingart, 2010).

De um ponto de vista diacrónico, podemos observar a emergência das práticas constituintes da Comunicação de Ciência sem a sua autonomia relativa contemporânea, podendo dar conta do processo constitutivo da relação actual entre os seus actores. Y. Gingras (1991) conceptualizou o processo de formação disciplinar em três fases: (1) a emergência de práticas teóricas e profissionais, (2) a sua institucionalização e (3) a consolidação de uma identidade socialmente reconhecida. Procuro aqui caracterizar a autonomia da Comunicação de Ciência a partir da história das ciências e da história das técnicas de comunicação com este processo de formação disciplinar como fundo.
\end{abstract}

\section{Pré-história da Comunicação de Ciência}

Independentemente das práticas medicinais, matemáticas e cosmológicas que surgem nos primeiros registos humanos, como na Chauvet-Pont-d'Arc, no Paleolítico Superior, na Mesopotâmia, no Egipto, na Índia e na China, é na Grécia Antiga que encontramos os suportes comunicacionais e teóricos para o desenvolvimento científico e comunicacional hodierno. O alfabeto foi inventado na Síria, mas só os Gregos é que desenvolveram um sistema estável 
de transcrição da língua falada em escrita, a retórica e as figuras da ágora e do museu, do ginásio, da academia e do liceu (Breton \& Proulx, 1997). Na filosofia desenvolveram-se vários programas de investigação: a busca dos archē de Tales de Mileto, Anaximandro, Anaxímenes e Pitágoras, a maiêutica de Sócrates, o programa de "salvar os fenómenos" atribuído a Platão e a teoria demonstrativa das causas de Aristóteles. O conhecimento das coisas da natureza foi desenvolvido na filosofia natural por autores como Platão, Aristóteles e Euclides. Em paralelo aflorou uma "tradição de manuais", que serviu para traduzir concepções mais abstractas e intelectualmente elaboradas numa linguagem mais simples, como nos textos de Eratóstenes de Cirene, Crates de Malos, Posidónio, Gémino, Cleomedes e Teão de Esmirna (Grant, 2002).

O Império Romano, estabelecido em I a.C., integrou essa tradição no ensino, e os seus enciclopedistas, como Vitrúvio, Séneca e Plínio, o Velho, desenvolveram uma tradição própria mas com funções semelhantes (ibid.). A epistēmē das aitiai aristotélica foi traduzida como scientia per causas e estabeleceu os critérios de demarcação da scientia. Os romanos construíram uma cultura prolixa do ponto de vista comunicacional e tecnológico: inventaram a argamassa, construíram estradas, aquedutos, banhos, esgotos e pontes, profissionalizaram a retórica, criaram os fóruns públicos e as recitationes, inventaram a carta e o álbum, criaram as Actas Populi e os Annalis do Colégio dos Pontífices. Depois da queda do Império, no séc. V, seguiu-se um período de desenvolvimento tecnológico e de circulação de conhecimentos com uma certa contiguidade (técnica e cognitiva), com os clássicos helénicos da filosofia natural e da matemática a serem traduzidos e comentados pelos povos muçulmanos (Ragep, 2013).

Na Europa Medieval surgiu a universidade. De um ponto de vista cognitivo, a universidade foi sempre universitas scientiarum, porque procurou cobrir a totalidade do saber por meio de uma distribuição hierárquica dos conhecimentos em conformidade com o programa das artes liberais (Pombo, 2002), que já tinha sido descrito, por exemplo, por Séneca. A comunicação enquanto elocução da razão teve um lugar central nas universidades por meio da disputatio, que podia ser ordinária, se inserida nas aulas, ou de quodlibet, se as questões fossem publicamente debatidas, habitualmente durante o Advento ou a Quaresma (Grant, 2002).

No Período Medieval surgiram as dissecações públicas em Bolonha, apareceram as crónicas, as cartas informativas e os relatos de viagens, aos quais 
se juntaram os almanaques e as folhas volantes do Renascimento. Entre 1444 e 1456, J. Gutenberg criou a imprensa. A última deu ao livro a função comunicacional de transporte de ideias e conferiu ao livro técnico um papel importante, com as obras latinas a passarem pelo prelo rapidamente (Breton \& Proulx, 1997). No Renascimento, a diferença entre um público especializado e um público não-especializado era sublinhada pela asserção de N. Copérnico de que "as Matemáticas são para os matemáticos" (Copérnico, 1566: 10). Ainda no Renascimento surgiram os primeiros hortus medicus, em Pádua e em Pisa, e os wunderkämmer, ambos incorporados, mais tarde, nas estruturas dos museus de história natural e nas universidades (Lourenço, 2003).

A filosofia natural aristotélica tal como foi formulada na Idade Média não teve flexibilidade para suportar os conhecimentos advindos da descoberta de novos mundos no séc. XV e das observações astronómicas do séc. XVI. Começou, por isso, a ser progressivamente substituída por um experimentalismo crescente e pelo uso de métodos matemáticos e quantitativos (Schmitt, 1973), como se observa nos Principia de I. Newton:

"Já que os antigos (...) tiveram em grande consideração a ciência da mecânica na investigação das coisas naturais; e os modernos, deixando de lado formas substanciais e qualidades ocultas, se têm esforçado por sujeitar os fenómenos da natureza às leis matemáticas, neste tratado eu cultivei as matemáticas na medida em que dizem respeito à filosofia" (Newton, 1686: 1xviii).

\section{Reconhecimento da natureza pública da actividade científica}

Nos sécs. XVI e XVII, a ciência foi objecto das discussões (em salões, cafés e associações) que estão na base da formação social setecentista de discursivização da experiência a que J. Habermas chamou "esfera pública literária" (Habermas, 1994). O aumento das taxas de alfabetização e a matéria e receptividade para notícias originadas pelas profundas transformações do séc. XVI, relacionadas com a expansão marítima e o aparecimento do colonialismo, com os conflitos da Reforma-Contrarreforma, com os confrontos entre parlamentaristas e monárquicos absolutistas e com as observações astronómicas de G. Galilei em diante, estão na base da derivação dos livros e opúsculos noticiosos em gazetas como La Gazzette Françoise de 1604 e o Niewe Antwersche Tijdinghe de 1605, pelo surgimento do protótipo dos jornais 
modernos, a Gazette de T. Renaudot, em 1631, e pelo lançamento do primeiro jornal americano, o Publick Occurrences Both Forreign and Domestick, em 1690, no mesmo ano em que T. Peucer apresentou a primeira tese de doutoramento sobre jornalismo, em Leipzig (Sousa, 2008). Quanto às associações de cientistas, estas existiam desde as guildas medievais de mestres, mas foi a partir do século XVI que começaram a ter um carácter mais formal. O Royal College of Surgeons de Edimburgo foi fundado em 1505. O Royal College of Physicians de Londres foi fundado em 1518. No século XVII começaram a surgir, em Itália, grandes associações de mecenato a cientistas, como a Accademia dei Lincei, criada em 1603, e a Accademia del Cimento, que surgiu em 1657. Estas associações marcaram a transição entre instituições lideradas por um patrono individual e as corporações consolidadas no século XVIII (Biagioli, 2003). As últimas começaram a formar-se sensivelmente a partir de 1652, com o nascimento, em território germânico, da Academia Naturae Curiosorum, a edificação da Royal Society em Londres, em 1660, e a criação da Académie des sciences em 1666, estabelecida no Louvre em 1699. A progressiva libertação da autoridade do patrono e da autoridade que Aristóteles atribuíra à opinião filosófica ou à percepção imediata dos fenómenos centralizou a experimentação enquanto lugar de execução da autoridade (Dear, 1985). A prática científica encontrou legitimidade na replicação pública das experiências laboratoriais - com muitas excepções, a começar por Newton. Também as transformações museológicas foram nesse sentido. Ainda no século XVI, apareceram os primeiros museus de ensino, em Leiden e Pisa, os museus de ensino anatómico, o primeiro em Leiden, e o estudo de colecções, primeiro em Bolonha e depois por toda a Europa. Em 1638, surgiu o Ashmolean Museum, o primeiro museu institucionalizado permitindo acesso a audiências externas à universidade (Lourenço, 2003).

Com o estabelecimento de um sistema de correio estruturado no século XVI, o género epistolar tornou-se fundamental nas estratégias de objectivação do conhecimento científico. À garantia de objectividade científica subjazia a legitimação dos pares distantes e a visão distanciada do próprio cientista em relação ao seu objecto (Daston, 1991). De facto, o Iluminismo, com pensadores como J. Locke ou G. W. Leibniz e I. Kant ou ainda J.J. Rousseau e D. Diderot, foi um período de redefinição das relações entre comunicação e ciência. Kant definiu Iluminismo enquanto emancipação - saída do homem do estado de menoridade por meio de tornar público um pensamento baseado 
nos princípios da razão, do uso público da razão (Kant, 1784). A. Lavoisier afirmou que entre os cientistas se formou uma "comunhão de opiniões" por intermédio de uma "comunicação" de ideias, observações e modos de ver (Lavoisier, 1776: xxviii-xxix).

No quadro do Iluminismo, é dada muita atenção à natureza pública da ciência. Além do objectivo de legitimar publicamente a ciência, a natureza pública da ciência serve ora para motivar ou desmotivar explicações religiosas, ora para mostrar a aplicabilidade dos conhecimentos científicos à vida prática, ora ainda para melhorar a saúde pública (Burns, 2003). Cientistas como J. T. Desaguliers, P. van Musschenbroek, P. Poliniere e A. Walker davam cursos e faziam demonstrações em público combinando "conhecimento científico" e "apresentação dramática" (ibid.). Neste contexto social emergiram as figuras da revista científica e do museu de ciência. Em 1665, a Royal Society publicou as Philosophical Transactions, e a Académie royale des sciences publicou o Journal des sçavans. Em 1668, Francesco Nazzari dirigiu o Giornale de' Letterati, e O. Mencke e Leibniz a Acta Eruditorum. O conhecimento científico espalhava-se também por via de jornais generalistas, como a Gazette ou o Mercure Galant, textos generalistas, como o Entretiens sur la pluralité des mondes, de B.B. de Fontenelle, de 1686, e textos destinados a um público feminino (mas lidos por todos os interessados em ciência), como o jornal The Ladies' Diary: or, Woman's Almanack a partir de 1704, o Newtonianism for Ladies de F. Algarotti de 1737 ou ainda os três volumes escritos por L. Euler das Letters to a German Princess, On Different Subjects in Physics and Philosophy, publicados entre as décadas de 60 e 80. Em 1752, em Madrid, abriu o Museo de Ciencias Naturales, e em 1793 foi fundado o Muséum national d'histoire naturelle em Paris.

\section{Autonomização do campo disciplinar da Comunicação de Ciência}

O séc. XVIII terminou com a Revolução Francesa e deu continuidade à Revolução Industrial Britânica. A imprensa foi ampliada pelo aparecimento de jornais burgueses e de jornais do operariado, a ligação à publicidade transformou o ofício jornalístico num negócio, e as tiragens aumentaram estrondosamente. Por exemplo, nos EUA passou-se de 9 milhões de exemplares em 1662 para 21 milhões em 1910 (Breton \& Proulx, 1997). A industrialização imprimiu nas técnicas de comunicação um movimento de expansão espacial 
através da melhoria de estradas, caminhos-de-ferro, transportes marítimos e correio e da invenção do telégrafo e, mais tarde, do telefone, da rádio, do cinema, da televisão e, hoje, da Internet (ibid.).

A ciência, por seu turno, sofreu uma contracção disciplinar. A ciência passou, a partir de 1750-1800, por um processo de especialização através de uma diferenciação interna e de uma diferenciação institucional. A autoreferencialidade dos objectos de análise colocou os problemas científicos num domínio restrito, num metadiscurso específico, partilhado apenas por um certo grupo, dando origem a um milieu intérieur em particular (Stichweh, 2001; Turner, 2000; Weingart, 2010). Esta especialização foi também causa e efeito da designação moderna das disciplinas, da emergência de várias revistas científicas, da disseminação de associações académicas de especialidade e da reforma da Universidade de Berlim (ibid.).

Ao contrário do que afirma a tese tradicional estabelecida no séc. XX, a especialização não separou ciência e sociedade, embora tenha complexificado em grande grau as relações entre ambas. Prova disso são as exposições mundiais e a clara necessidade da organização da circulação do conhecimento em sociedade. De facto, desde o final do séc. XVIII que várias nações ergueram feiras para exposição dos desenvolvimentos tecnocientíficos e industriais, destacando-se a Great Exhibition de Londres de 1851 e a Exposition Universelle de Paris de 1855. Por outro lado, anos antes, em 1826, foi fundada a Society for the Diffusion of Useful Knowledge, que convidou M. Somerville a traduzir a Mécanique Céleste de P.S.M. de Laplace. Os textos que Somerville escreveu a partir de então foram muito relevantes para o campo da Comunicação de Ciência, nomeadamente o On the Connexion of the Physical Sciences, de 1834. O primeiro uso do termo 'cientista' data precisamente de uma recensão que W. Whewell fez a esse livro, publicada em 1834 (Ross, 1962). Em 1857, foi fundado o Science Museum de Londres, e o American Museum of Natural History surgiu em 1869. Ciência era tema usual nas publicações jornalísticas entre 1870 e 1885 (Bauer, 2004). Em 1869 apareceu a Nature, em 1880 a Science. Por esta altura nasceu a figura do jornalista de ciência, com W. Kaempffert, editor de ciência do New York Times, J. Stafford, J. Pfeiffer e G. Piel, fundador da Scientific American em 1948. Todos estes factos dão conta de uma relação entre ciência e sociedade em profunda transformação.

No século XX o ponto de encontro entre comunicação e ciência dá-se na noção de 'inovação tecnológica'. A aceleração crescente por intermédio 
do aparecimento de novas tecnologias aplicadas ao conhecimento científico e aos meios de comunicação pluralizou os sentidos dos termos 'ciência' e 'comunicação', transformando muito possivelmente também as suas naturezas. Hoje falamos, por isso, de 'ciências' e de 'comunicações'. J. Dewey, que na transição de século considerava que a existência da sociedade decorria na comunicação e que era a inquirição científica que permitia a inteligibilidade da experiência, julgava que havia mais circulação de informações acerca de ciência do que uso do conhecimento científico para educar os públicos:

"A comunicação de ciência enquanto objecto tem ultrapassado mais a construção de um hábito científico mental, até agora, na educação, do que o bom senso natural à humanidade, em certa medida, tem interferido no seu detrimento" (Dewey, 1910: 126).

De facto, ao longo do século XX, assistimos a várias vagas da ciência enquanto tema a preencher a agenda mediática, principalmente nos anos 20 , entre 55 e 65 e a partir de meados da década de 80 (Lewenstein, 1997; Bauer, 2004). O interesse pela ciência aumentou sucessivamente, o que é bem visível na formalização da abordagem da "Literacia Científica", em 1958, por P. Hurd. Esta abordagem seria o paradigma político e educacional da Comunicação de Ciência em potência (Laugksch, 2000). Subjacente estava um modelo epistemológico de comunicação enquanto transmissão vertical de conhecimento entre um corpo especializado e um público ignorante que assimila o conhecimento transmitido. De acordo com M. Bucchi (1998) e P. Maeseele (2013), este modelo tem tido várias designações: "paradigma da comunicação de risco", "preocupação dominante", "explicação canónica", "visão dominante", "modelo da popularização"; "posição racionalista", "abordagem tecnocrática", "modelo difusionista", "modelo tradicional", etc. Estas ideias têm figurado sob o signo da "popularizing science" nos países anglo-saxónicos, "vulgarization" nos países de língua francesa, "divulgación" e "divulgação" na Península Ibérica e "social appropriation of science" na América Latina (Lewenstein, 2010).

Em 1985, a Royal Society of London publicou um relatório intitulado "The Public Understanding of Science", no qual se afirma que os cientistas devem ser capazes de apresentar os seus projectos a uma audiência ampla e que devem aprender como funcionam os meios de comunicação (RS, 1985). O objectivo central era o de aproximar a ciência do público. O modelo subjacente 
continuava a ser o difusionista, porém a atenção dada ao público direccionou a análise para as condições de recepção (Ziman, 1991). Logo no início dos anos 90 começou a falar-se de "Ciência na Sociedade", depois de ter sido diagnosticada uma perda de confiança do público relativamente à ciência, cristalizada num relatório da House of Lords de 2000 (Bauer, Allum \& Miller, 2007). Esta relação entre imagem pública da ciência e establishment científico foi a última gota de um copo cheio. Tornou evidente a necessidade de institucionalizar a Comunicação de Ciência. Em 1991 apareceu um dos primeiros cursos em Comunicação de Ciência - no Imperial College de Londres (Mellor, 2013). Um ano depois começou a ser publicada a Public Understanding of Science. Daí em diante, cursos, conferências, revistas e livros multiplicaram-se.

\section{Considerações finais}

A identidade cognitiva da Comunicação de Ciência está agora assegurada pela partilha de teorias e modelos. Mas a identidade sociocultural e profissional é atravessada por uma relação de tensões entre os papéis dos jornalistas de ciência, dos cientistas divulgadores e dos curadores de museus e centros de ciência, visto que as suas práticas profissionais estão dentro dos limites da Comunicação de Ciência mas as suas posições têm origem em campos diferentes, tal como acontece com os investigadores de História, Filosofia e Sociologia das Ciências e dos Estudos de Comunicação que fazem da Comunicação de Ciência seu objecto. Ainda assim, como mostrei, os pontos de intersecção entre o desenvolvimento científico e o desenvolvimento comunicacional na génese da Comunicação de Ciência são fundamentais para a compreensão do seu estado actual e, por conseguinte, para análises futuras destas tensões identitárias.

\section{Referências bibliográficas}

Bauer, M.W. (2004). The Vicissitudes of Public Understanding of Science: from Literacy to Science in Society. In J. Caraça, A.F. Costa, R. Gerold, M.W. Bauer, P. Caro, M.E. Gonçalves \& M. Mosley, Science Meets Society (pp. 39-65). Lisboa: Fundação Calouste Gulbenkian. 
Bauer, M.W.; Allum, N. \& Miller, S. (2007). What can we learn from 25 years of PUS survey research? Liberating and expanding the agenda. Public Understanding of Science, 16(1): 79-95.

Biagioli, M. (2003). Galileu Cortesão. A prática da Ciência na Cultura do Absolutismo. Porto: Porto Editora.

Breton, P. \& Proulx, S. (1997). A Explosão da Comunicação. Lisboa: Bizâncio.

Bucchi, M. (1998). Science and the Media: Alternative Routes in Scientific Communication. London/New York: Routledge.

Burns, W.E. (2003). Science in the Enlightenment. An Encyclopedia. Santa Barbara: ABC-CLIO.

Copérnico, N. (1984 [1543/66]). As Revoluções dos Orbes Celestes. Lisboa: Fundação Calouste Gulbenkian.

Daston, L. (1991). The ideal and reality of the Republic of Letters in the Enlightenment. Science in Context, 4(2): 367-386.

Dear, P. (1985). Totius in verba: Rhetoric and Authority in the Early Royal Society. Isis, 76(2): 144-161.

Dewey, J. (1910). Science as Subject-Matter and as Method. Science, 31 (787): 121-127.

Gingras, Y. (1991). L'institutionnalisation de la recherche en milieu universitaire et ses effets. Sociologie et societés, 23(1): 41-54.

Grant, E. (2002). Os Fundamentos da Ciência Moderna na Idade Média. Porto: Porto Editora.

Habermas, J. (1994). The Structural Transformation of the Public Sphere: an inquiry into a category of bourgeois society. Cambridge: MA: The MIT Press.

Kant, I. (1996 [1784]). An Answer to the Question: What is Enlightenment?. In J. Schmidt, (Ed.), What is Enlightenment? Eighteenth-Century Answers and Twentieth-Century Questions (pp. 58-64). Berkeley/Los Angeles/London: Cambridge University Press.

Kuhn, T. (1996 [1962]). The Structure of Scientific Revolutions. Chicago: The University of Chicago Press. 
Lavoisier, A. (1776). Discours Préliminaire. In A.Lavoisier, Traité Élémentaire de Chimie, présenté dans un ordre nouveau et d'après les découvertes modernes, avec figures, Tome premier (pp. V-XXXII). Paris: Chez Cuchet.

Laugksch, R.C. (2000). Scientific Literacy: A Conceptual Overview. Science Education, 84(1): 71-94.

Lewenstein, B.V. (1997). Communiquer la science au public: l'émergence d'un genre américain, 1820-1939. In B. Bensaude-Vincent \& A. Rasmussen (Eds.), La science populaire dans la presse et l'édition : XIX et XX siècles (pp. 143-153). Paris: CNRS Editions.

Lewenstein, B.V. (2010). Modelos de comprensión pública: la política de la participación pública. ArtefaCToS, 3(1): 13-29.

Lourenço, M. (2003). Contributions to the history of university museums and collections in Europe. Museologia, 3: 17-26.

Maeseele, P. (2013). On media and science in late modern societies. In E. Cohen, (Ed.), Communication Yearbook 37 (pp. 154-181). New York: Routledge.

Mellor, F. (2013). Twenty years of teaching science communication: A case study of Imperial College's Master's programme. Public Understanding of Science, 22(8): 916-926.

Newton, I. (1846 [1686]). The Mathematical Principles of Natural Philosophy. New York: Daniel Adee, 45 Liberty Street.

Pombo, O. (2002). A Escola, a Recta e o Círculo. Lisboa: Relógio D'Água.

Ragep, J. (2013). Islamic Culture and the Natural Sciences. In D.C. Lindberg \& M.H. Shank, (Eds.), The Cambridge History of Science, vol. 2. Medieval Science (pp. 27-61). New York: Cambridge University Press.

Ross, S. (1962). Scientist: The story of a word. Annals of Science, 18(2): 65-85.

Royal Society (1985). The Public Understanding of Science. London: Royal Society.

Shank, M.H. (2013). Schools and Universities in Medieval Latin Science. In D.C. Lindberg \& M.H. Shank, (Eds.), The Cambridge History of Science, vol. 2. Medieval Science (pp. 207-239). New York: Cambridge University Press. 
Schmitt, C.B. (1973). Towards a reassessment of renaissance Aristotelianism. History of Science, 11: 159-193.

Sousa, J.P. (2008). Uma História Breve do Jornalismo no Ocidente. Biblioteca On-line de Ciências da Comunicação. Disponível em: www.bocc.ubi.pt.

Stichweh, R. (2001). Scientific Disciplines, History of. In N.J. Smelser \& P.B. Baltes, (Eds.), International Encyclopedia of the Social and Behavioral Sciences (pp. 13727-13731.). Oxford: Elsevier Science.

Turner, S. (2000). What Are Disciplines? And How Is Indisciplinarity Different?. In P. Weigart \& N. Steher, (Eds.), Practicing Interdisciplinarity (pp. 46-65). Toronto: University of Toronto Press.

Weingart, P. (2010). A short history of knowledge formations. In R. Frodeman, J.T. Klein, \& C. Mitcham, (Eds.), The Oxford Handbook of Interdiscilinarity (pp. 3-14). Oxford: Oxford University Press.

Ziman, J. (1991). Public Understanding of Science. Science, Technology \& Human Values, 16(1): 99-105. 


\title{
Considerações sobre os desafios múltiplos da Ciência Aberta
}

\author{
Tiago Lima Quintanilha \\ OberCom, ISCTE-IUL, CIES-IUL \\ E-mail: Tiago.lima@obercom.pt
}

\begin{abstract}
Resumo
Este é um artigo que tem por objectivo perceber e dar resposta a um conjunto de desafios que começam a ser associados ao modelo de ciência aberta, depois do período de novidade com o surgimento do modelo de publicações electrónicas baseadas no peer-review, na primeira metade da década passada. $O$ facto de só recentemente se começarem a debater as implicações principais que colocam grandes interrogações ao que se pretende ao nível do modelo de ciência aberta, acaba por ter repercussões no iniciático estado da arte disponível. Ao longo deste texto faremos alusão ao percurso histórico do fenómeno a que se convencionou desig-

nar como ciência aberta, para de seguida elencarmos um conjunto de questões que conferem uma certa noção de volatilidade a este modelo de publicação científica, nomeadamente ao nível da sustentabilidade financeira dos centros de investigação que suportam as referidas publicações; a condição de informalidade e incumprimentos vários por parte dos facilitadores do processo; o conflito de expectativas; o perigo da indústria paralela e parasitária; a fraca uniformização de processos necessários ao modelo de boas práticas científicas; a produção em massa que gera problemas de validação e verificação, entre outros assuntos.
\end{abstract}

Palavras-chave: Ciência aberta; sustentabilidade; desafios.

\begin{abstract}
This article tries to understand and respond to a set of challenges that somehow appear to be associated with the Open Science model. After the new period that emerged from a concept of electronic publications based on peer reviewed rese-

arch, scientific community is now slowly but surely focusing on problems that pose significant challenges to the sustainability of the Open Science model. The fact that this is a recent discussion ends up having repercussions on the available ini-
\end{abstract}


tiatory state of the art. The paper starts with making reference to the historical background of the phenomenon that is conventionally designated as Open Science. Furthermore, it focuses on discussions about significant number of issues that confer a certain notion of volatility to this scientific publishing model, particularly in terms of its financial sustainability; the informality and multiple failures related to the evaluation process that happens to be called as the ineffectiveness of the facilitators; the danger of a parallel and parasitic industry; the poor standardization of necessary measures aiming to fulfill good scientific practices; the problem of mass production that leads to validation and verification problems; and among other topics.

Keywords: Open science; sustainability; challenges.

\section{Introdução}

O final da agenda europeia para o catching up, quando era óbvio o dé1 fice de plataformas competitivas, a declaração de Berlim (2003) permitiu formalizar a mudança do paradigma de construção científica, partindo da ideia de que a disseminação de conhecimento passaria por torná-lo disponível em larga escala. $\mathrm{O}$ movimento estabelecia quatro pontos essenciais: suporte às publicações em Open Access e apoio à investigação e publicação neste formato por parte de investigadores e bolseiros de investigação científica; apoio e estímulo à publicação, tirando partido de plataformas de largo alcance (Internet); apoio ao desenvolvimento de formas de avaliação em Open Access, por forma a garantir qualidade científica e boas práticas de produção de conhecimento; e o pressuposto de compensação menos focada na propriedade e direitos autorais, e mais em termos de prestígio e alcance da produção. $\mathrm{O}$ percurso não foi imediato. De conceitos iniciais, como ciber-ciência, ciberinfraestrutura, e-science, e-research, o trajecto feito levou-nos à designação hoje conhecida como Ciência Aberta (Open Science), numa lógica assente em dois pressupostos principais que passavam por reconhecer o obsoletismo de uma cultura académica tradicional, de conhecimento fechado, quase sigiloso, e o necessário surgimento de uma objectividade científica construída num formato comunitário de um universo de colaborações em rede, potenciadoras de uma cumulatividade mais rápida e minimizando mais eficazmente os perigos 
do conhecimento duplicado. Por outras palavras, o objectivo passava por reinventar uma estrutura anacrónica de produção-difusão de conhecimento, com fraco alcance, quase privada e auto-centrada, para uma estrutura descentralizada em dinâmicas horizontais de colaboração entre pares. (Castells, 2002). Yochai Benkler (2006) designava o processo como "peer-production".

\section{Enquadramento histórico}

Este tema não deve ser interpretado sem antes ser feita uma análise histórica. Porque perceber estas novas formas de fazer ciência é, primeiro do que tudo, falar dos processos e mecanismos facilitadores de tal mudança. É perceber o que se passa ou tem passado em termos de evolução tecnológica e as suas repercussões na forma de pensar e produzir conteúdos, bem como a importância daquilo a que se convencionou chamar de Sociedade da Informação na intermediação desta mudança. Pois bem, a sociedade da informação está inserida num processo de mudança em que as novas tecnologias são os principais facilitadores. Segundo o Livro Verde para a Sociedade da Informação em Portugal, este modelo de organização das sociedades assenta num modo de desenvolvimento social e económico onde a informação, como meio de criação de conhecimento, desempenha um papel preponderante na produção de riqueza e contribuição para o bem-estar e qualidade de vida dos cidadãos.

$\mathrm{O}$ avanço da sociedade da informação é a possibilidade de todos poderem aceder à informação produzida. Tal como descrita nos quadros de referência da UNESCO, "A Sociedade da informação é a pedra angular das sociedades do conhecimento". No fundo, a Sociedade da Informação é o veículo potenciador da transmissão de conhecimento, e, no caso das revistas electrónicas, materializadas numa plataforma de longo alcance, o modelo online é a condição máxima por que se regem a produção, revisão, divulgação e disseminação do conhecimento científico. E é aqui que surge a relação da Ciência Aberta com as questões levantadas para a Sociedade da Informação e suas bases tecnológicas, no sentido em que esta última surge como o facilitador da transição de uma ciência de publicação tradicional, auto-centrada e fechada, para uma ciência mais aberta, de consulta gratuita.

Em termos mais gerais, por assim dizer, e só para termos ideia da amplitude desta problemática, podíamos recordar a própria concepção da Agenda de Lisboa, numa altura em que, como já referido, a Europa começava a per- 
der terreno face aos Estados Unidos (início da década de 90), num período de fim do catching-up Europeu aos países mais desenvolvidos (Japão e EUA), tendo ficado claro que criar novas plataformas competitivas era fundamental para sustentar o modelo Europeu. A ideia passou então por preparar a transição para uma economia e uma sociedade baseadas no conhecimento, através da aplicação de melhores políticas no domínio da sociedade da informação e seu acesso generalizado, e da inovação e desenvolvimento tecnológico. Assim, "passou a ser claro que não era possível construir uma sociedade baseada no conhecimento sem uma política de investigação e desenvolvimento mais ambiciosa, que se pudesse aproximar daquela que era praticada pelo modelo americano. A razão era simples: apenas com a aposta nas I\&D passa a ser possível constituir uma fonte essencial de criação de conhecimento, que desempenhe um papel crucial na compreensão do mundo em que vivemos e também na melhoria da competitividade, da qualidade de vida, da coesão social e dos modelos de governação" (Rodrigues: 2009).

E como era percebida a ciência?

Para Cribb (2010), a ciência, na sua génese, incorporava o ideal de servir a humanidade, sendo indispensável ao progresso civilizacional, desde que os seus intervenientes se comprometessem com padrões éticos necessários. No entanto, ciência era poder e o sistema que contribuía para lhe dar forma visava não a partilha ou a igualdade, mas sim a sua exclusividade, domínio e propriedade. É aqui que entra a necessidade de partilha de conhecimento, factor que também está na génese do reinventar das formas de divulgação e disseminação do conhecimento científico, algo a que se convencionou chamar de processo de democratização da ciência (Cribb: 2010).

Como refere Daston (1999:91, citado por Cardoso e Jacobetty, 2010), “a ciência é composta por um conjunto de práticas sistemáticas de pesquisa e investigação que têm por objectivo a criação de conhecimento sobre a realidade. Na procura do conhecimento sobre a realidade, a conquista da objectividade científica é operada de forma comunitária, um universo de colaborações estimulado por melhorias nos meios de transporte e comunicação, criando as redes de observadores cada vez mais vastas e densamente relacionadas". Jankowski (2007) dizia então que a essência da ciência estava a mudar. Para Cardoso e Jacobetty (2010), "estas mudanças resultavam principalmente da utilização de redes electrónicas que facilitavam o contacto entre investigadores, e de unidades de computação com elevada capacidade de processamento e 
armazenamento, que passaram a permitir trabalhar grandes volumes de dados num curto espaço de tempo. Actualmente, componentes informáticos e das TIC estão integrados na maioria dos processos de produção e distribuição do conhecimento científico. Uma boa parte do trabalho científico mais comum tem suporte electrónico: elaboração de textos, comunicação entre cientistas, et cetera, são exemplos de tarefas onde a aplicação das novas tecnologias é generalizada. Conseguimos assim colmatar certas limitações técnicas que previamente impediam um dado progresso da Ciência. (...) A utilização da Internet e das TIC no trabalho científico começava a dar origem a transformações nas formas de fazer Ciência. As possibilidades de comunicação e transmissão de dados entre investigadores deram origem a novas formas de percepção sobre as possibilidades da Ciência e também sobre a sua missão. A problemática de abertura das ciências nascia como fruto deste novo contexto comunicacional." Os mesmos autores continuam, referindo que "as novas ferramentas disponibilizadas aos cientistas, principalmente através de plataformas na Internet, traziam alterações ao modelo de produção científica, permitindo, entre outras coisas, maiores níveis de colaboração, internacionalização, transparência e impacto do trabalho científico. Assim, a configuração de um novo modelo científico que surgia como potenciador de inovação, passava a ser alvo de interesse por parte de académicos, instituições e entidades governamentais. $\mathrm{O}$ modelo Open Science estruturava-se principalmente em três níveis: partilha de ferramentas de pesquisa; partilha de dados e partilha de acesso na forma de publicações. Ainda assim, o conceito, pelo menos em termos mais gerais, não era na altura inteiramente consensual, havendo por isso uma série de denominações criadas ao longo dos anos prévios, que mais não eram do que uma espécie de upgrade epistemológico de um acontecimento que se tornava cada vez mais evidente." (Cardoso e Jacobetty: 2010).

Nentwich (2005) começou por falar em Ciber-Ciência, para definir "toda a actividade de pesquisa académica e científica no espaço virtual gerado pela rede informática e pelas tecnologias avançadas de informação e comunicação no geral".

"Outra ideia avançada foi a de Atkins, que falava já numa ciber-infraestrutura que estava para a Economia do Conhecimento como as infra-estruturas modernas. Por outro lado, em 1999, falava-se de e-ciência, a ciência de larga escala que iria basear-se cada vez mais em colaborações globais distribuídas e possibilitadas pela internet. Já o termo e-research surgia como mais con- 
sensual nos meios académicos ligados às ciências sociais e humanidades que integravam as potencialidades da internet, hipertexto, visualização virtual e comunidades cibernéticas. (...) Chegou-se então ao conceito de abertura científica com maior abrangência e que passou a ser designado como Open Science, reflectindo a disponibilização dos vários produtos do processo de pesquisa, desde a fase de observação e recolha de dados, à sua forma final sob a forma de publicações. Estruturava-se também enquanto alternativa complementar à estratégia da propriedade intelectual relativa à produção e distribuição de informação, partindo do pressuposto de que a privatização de dados e informação tendia a atrasar o avanço científico, tal como o progresso económico e social. Este regime de propriedade conduzia a situações de escassez artificial, que poderiam ser eliminadas através das funcionalidades desenvolvidas no meio digital, em especial na internet (Cardoso e Jacobetty: 2010).

"Para Paul A.David (2003), a Ciência Aberta era vista como o modelo científico alternativo ao modelo de propriedade intelectual de alocação de recursos para produção e distribuição de informação, que dependia de um sistema de incentivos não mercantis. Segundo o autor, os custos de acesso impostos pelos detentores de direitos de propriedade intelectual sobre o conhecimento técnico e científico tinham consequências nefastas para programas de pesquisa exploratória, considerados vitais para a Economia do Conhecimento. A definição de Ciência Aberta, segundo J. Daniel Gezelter, prendia-se com a transparência na metodologia experimental, a disponibilização pública, com possibilidade de reutilização dos dados científicos; disponibilização pública e transparência na comunicação científica e utilização de ferramentas Web para facilitar a colaboração científica. (...) A competitividade e o secretismo que pautaram o trabalho científico em tempos pareciam já não se enquadrar nas novas visões da ciência de um número crescente de investigadores. A internet estava a tornar-se um suporte para os cientistas disponibilizarem notas laboratoriais e as primeiras descobertas, aumentando o ritmo de progresso científico e integrando uma dimensão de debate mais alargada. Estas novas práticas não se enquadravam na cultura académica tradicional, em que tipicamente o cientista trabalhava só e sem revelar os resultados até à sua publicação, sem aprofundar todos os detalhes do processo de pesquisa. Isto permitia-lhes disponibilizar os seus resultados e as suas notas laboratoriais para outros, em qualquer ponto do globo. Permitia também alargar o debate dentro e fora da 
academia, integrando contribuições e aumentando a possibilidade de interdisciplinaridade. (idem)".

A principal valência do modelo visava sobretudo colmatar aquilo a que Cribb (2010) designou por falhanço nos veículos de transmissão das conquistas tecnológicas, na medida em que o conhecimento científico duplicava a cada 5 anos, mas a sua distribuição encontrava barreiras que tornavam o seu alcance (num planeta de 7 biliões de habitantes) e distribuição duas perfeitas miragens, devido aos veículos de divulgação fechados característicos da ciência tradicional.

\section{A sustentabilidade do modelo e seus perigos crescentes}

1) A condição a montante e o desinvestimento em centros responsáveis pelas diferentes publicações periódicas em acesso aberto

Tudo era novidade no modelo de Ciência Aberta. Mais de uma década depois, as primeiras dúvidas, ou o perigo da insustentabilidade a prazo. Em primeiro lugar, nenhuma resistência ao modelo. Contudo, há sérias questões que poderão estar a levantar dúvidas quanto à sustentabilidade e essência desse mesmo modelo. Se pegarmos nos pontos de apoio à construção do manifesto, verificamos uma espécie de abrandamento na eficácia da acção e do alcance dos facilitadores, por assim dizer. Começando pelo primeiro ponto, e especificamente no caso português, existe como que uma resistência a nível macro, governativo, institucional, o que se quiser chamar, ao próprio modelo. E essa resistência é, primeiro que tudo, contraproducente. O momento inicial de ciência aberta, apoiado pela Fundação para a Ciência e Tecnologia, no formato de verba, fundo ou incentivo, deu lugar, no início desta década, a uma espécie de retrocesso radicado na ideia de que era necessário alocar os incentivos e verbas disponíveis, exclusivamente ao apoio à edição de publicações não periódicas. Incompreensivelmente, os recursos passaram a ser unicamente direccionados a um tipo de publicação (como as monografias) bastante mais próxima do modelo convencional de alcance mais curto, num revisitar do processo tradicional onde a impressão e o arquivo em estante são características mais óbvias. Os centros de investigação, grandemente responsáveis pela existência e gestão dos e-journals, num momento que, já por si, representava um desinvestimento dos fundos para a ciência, passaram a ter de incluir nos 
orçamentos anuais a cada vez maior despesa que este tipo de publicações periódicas suscitam. Dos processos de proofreading, passando pela formatação e edição de textos, bem como do arquivo online e aluguer de servidores, e terminando no escrutínio e exigências cada vez mais prementes dos múltiplos indexadores, com novas formas de tratamento de texto, muitos são os desafios que se vão colocando à existência destas revistas, no formato de ciência aberta, com a clara repercussão que, a prazo, todo este peso poderá assumir na descontinuidade de algumas publicações. E neste pressuposto, num momento de fracos recursos, só as publicações mais fortes irão resistir, na certeza de que um filtro criado por via da disponibilidade financeira das diferentes publicações, é um filtro que não redunda necessariamente em maior qualidade e que põe em causa as bases de sustentação do modelo de ciência aberta, segundo a máxima de democratização da ciência. 
Figura 1. Fundos de apoio à comunicação científica, dos quais não consta nenhuma referência às publicações periódicas de natureza científica, em processo contínuo e em modelo aberto

Fundo de Apoio à Comunidade Científica

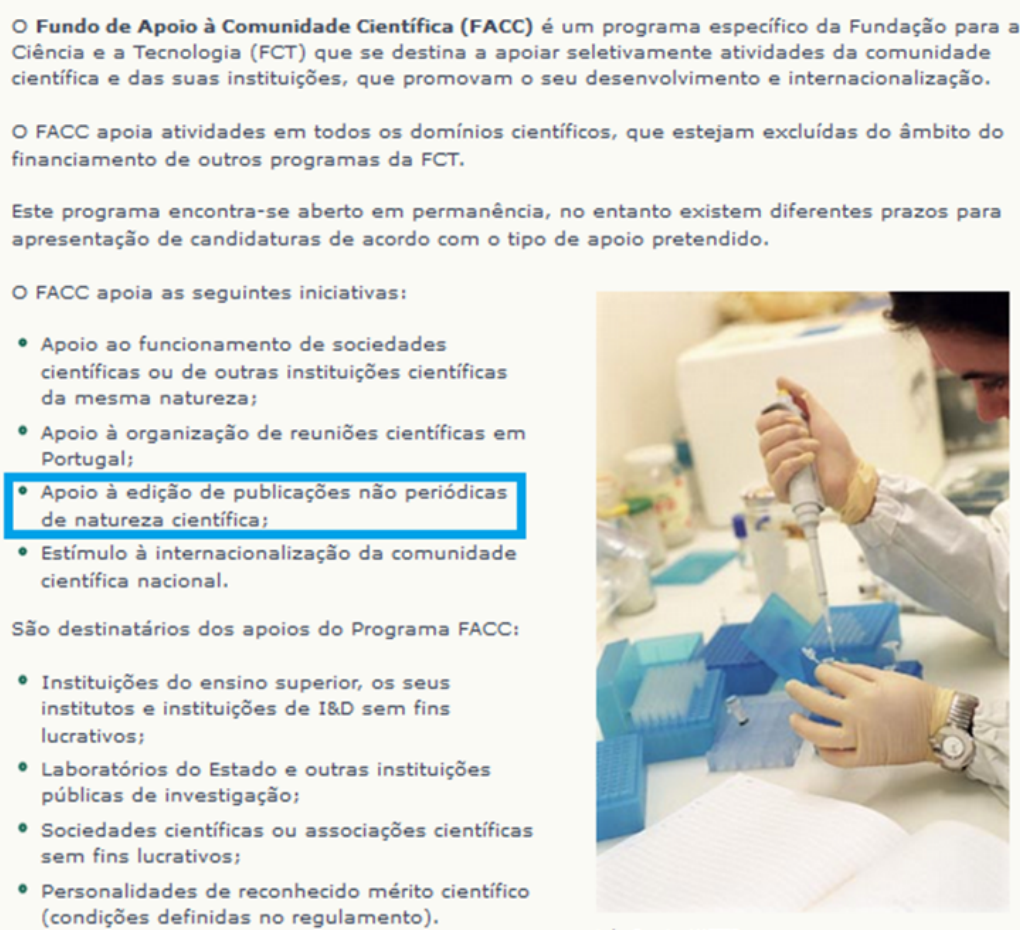

(condições definidas no regulamento).

Fonte: www.fct.pt

2) A falta de uniformização das avaliações e o perigo da arbitrariedade da decisão. O precário controlo da qualidade.

O segundo grande desafio reside no perigo que é olhar para a qualidade científica e as boas práticas de produção de conhecimento como metas adquiridas. O perigo aqui tem que ver com as próprias características do modelo e com a informalidade de todo o processo. Contudo, esta informalidade pode resultar em não comprometimento, algo que, numa revista em formato tradicional, sustentada por um corpo editorial de avaliação fixo, não sucede tão 
facilmente. Esta informalidade, traduzida em maior arbitrariedade nos processos de decisão e avaliação de artigos, consubstancia-se em resultados e em avaliações que não seguem um mesmo padrão, ou, por outras palavras, uma uniformização necessária que fica aquém, em múltiplos parâmetros de avaliação que diferem de artigo para artigo. Dito de outra forma, o problema maior reside no facto de um artigo A, com uma qualidade aceitável, ser preterido para um número de revista, por um artigo $\mathrm{B}$, de menor qualidade, sendo que o contexto aponta, vamos supor, para uma avaliação A que é minuciosa, exaustiva e actual, e uma avaliação B que é negligente, leviana e superficial. Ora, é aqui que entra a condição de informalidade e o perigo da não uniformização de processos. As agendas e as cargas de trabalho de professores e académicos tendem a encarregar-se deste fenómeno, no sentido em que, aliadas ao comprometimento da pessoa destacada para o processo de revisão, e a sua defesa, ou não, da causa, desempenham um quadro de volatilidade que se reflecte numa utopia do modelo avaliativo perfeito, capaz de premiar o mérito em função de uma escala decisória não sujeita a oscilações. Christopher Bare (2014), um dos grandes críticos do modelo, fala já do facto de o peer review ser um processo descompensado e ineficaz. Uma das razões também avançadas pelo autor, para o falhanço de uma avaliação eficaz, traduz-se na lentidão dos processos avaliativos, que redunda na facilidade com que alguns artigos acabam por ficar datados, mesmo aqueles que passam para uma fase de aceitação e edição. Para além disto, Priem (2012) refere que, na base do modelo avaliativo, está muitas vezes inculcada a ideia de olhar para o artigo apenas do ponto de vista do quão bem trabalhado este está metodologicamente, descurando a parte importantíssima de saber se o artigo terá um impacto significativo e potencial numa lógica de conhecimento cumulativo, pervertendo-se assim por completo, em muitos casos, o sentido do incremento do conhecimento como condição primária do processo avaliativo. Bare (2014) vai mais longe e sugere que, no sentido de validar a qualidade de cada artigo, deverá começar a surgir um processo duplo de revisão pós-publicação em combinação com alguma forma de filtragem algorítmica capaz de aferir a qualidade do artigo. Um processo que deve ser contínuo, portanto, na medida em que de um modelo de avaliação não uniformizado resultam perigos de desadequação dos momentos de decisão.

Para Casati (2006), há várias características associadas às revisões por pares, que podem levar a uma revisão enviesada. A saber: 1) por vezes, bons 
artigos são rejeitados em função de más revisões. A principal razão prende-se com o facto de uma avaliação baseada na rejeição do artigo ser uma avaliação fácil de fazer e que não necessita de grande elaboração. Por outro lado, as revisões são por vezes inconsistentes e as críticas feitas são por vezes opostas ao real conteúdo do artigo; 2) há avaliadores que, no geral, aplicam critérios baseados mais nos aspectos negativos e outros que se baseiam em aspectos mais positivos dos artigos. 3) muitas vezes, depois de uma revisão que até pode ser escrupulosa, os autores preocupam-se mais em adaptar e dar as voltas pedidas pelos revisores, do que propriamente trabalhar num contexto diferente capaz de dar resposta às principais dúvidas; 4) as diferentes revisões a cada artigo podem produzir comentários antagónicos, levando a uma maior dificuldade por parte dos autores em dar resposta às alterações pedidas.

3) A informalidade do processo e o perigo da falta de comprometimento por parte dos facilitadores do modelo

$\mathrm{O}$ terceiro grande perigo reside naquilo a que podemos designar como conflito de expectativas. Aqui não se trata de perceber que há diferentes percepções que são tão normais quanto saudáveis e que resultam de diferentes entendimentos de um mesmo artigo, por parte dos seus autores e dos avaliadores destacados para o processo de revisão. Esta é a parte benigna de todo o processo, mesmo em fenómenos de atrito mediado pelo corpo editorial da revista. $\mathrm{O}$ conflito de expectativas deve-se, isso sim, à celeridade exigida em cada processo de avaliação, muitas vezes contrária ao bom e regular funcionamento das publicações, e que não encontra correspondência na outra tarefa implícita a cada autor publicado. O perigo de perceber a publicação como prioritária e, em contrapartida, a avaliação como aspecto secundário ou até uma espécie de fardo. O perigo de não perceber que, em caso de dualidade e conflito de expectativas, a publicação alheia pode ser comprometida pela incapacidade que um autor publicado tem em perceber que um trabalho seu só foi efectivamente publicado, porque o avaliador destacado para o seu artigo se disponibilizou a desempenhar as duas fases vitais ao processo (chamemos-lhe defesa da causa). Pegando no exemplo anterior, se um autor A submete um trabalho A, é expectável que, a dada altura do seu ciclo de vida como utilizador da revista, este autor A seja convidado a decidir sobre a qualidade de um artigo nas áreas em que declaradamente fez formação e exerceu trabalho de investigação. E ao fazê-lo, deverá garantir que o segundo desafio já elen- 
cado, não se coloque, decidindo-se pelo desempenhar de uma avaliação clara e minuciosa do trabalho proposto para análise, e não pelo declinar da tarefa de revisão, assim tenha cumprido o desejo de publicar nessa revista. Por outras palavras, um modelo construído na lógica da publicação prioritária, em detrimento de uma avaliação tida essencialmente como sendo um aspecto secundário e quase descartável, é um modelo insustentável e um modelo que se traduz num aumento progressivo do volume de artigos em processo de avaliação que não são acompanhados pelo necessário número de avaliadores comprometidos com a revista. Em termos de comparação, podemos recordar o que se passa com os modelos de P2P. Neste modelo, há dois tipos de actores no desenrolar do processo. Em primeiro lugar, temos os seeders, aqueles que alimentam todo o fenómeno e que, em virtude da sua função de facilitadores, fazem chegar ao destinatário o conteúdo desejado, como é o caso de um filme, por exemplo. No lado oposto, temos a "sanguessuga" (que vem de leecher), no verdadeiro sentido da palavra, que equivale a dizer que é aquele que tira benefício do modelo em causa (neste caso, o acesso ao filme), mas que não contribui depois para o fenómeno da partilha. Esta "sanguessuga", depois do download e da visualização do filme, limita-se a classificar a experiência, ao limite, e a decidir-se pelo arquivo privado ou destruição do ficheiro em causa, quebrando ali a corrente de partilha do ficheiro conseguido por via de uma lógica altruística anterior. Ora, um autor publicado e reconhecido pela revista, que não está para grandes esforços no que à avaliação de artigos diz respeito, numa lógica declarada de não contribuição, não é mais do que uma "sanguessuga" a operar neste processo, beneficiando das grandes virtudes do modelo, mas escusando-se a ser parte integrante do mesmo. E num contexto hipotético de "sanguessugas" em larga escala, nenhum modelo erguido da construção entre pares poderá sobreviver. Este parece ser um ponto assente, de tal forma que o próprio programa da EU para a investigação e inovação refere que "alguns desafios precisam de ser tidos em conta, como direitos de propriedade intelectual, métricas alternativas, content mining, mas também desafios do foro inter-institucional, inter-disciplinar e colaboração internacional entre todos os actores envolvidos em investigação e inovação" (The EU framework programme for research and innovation: Horizon 2020).

4) Os parâmetros de decisão na escolha dos avaliadores. O perigo da flexibilização da escolha em função das necessidades da revista 
Este fenómeno adverso ao modelo foi já discutivo por Jason Priem e Bradley Hemminger (2012), quando se reportaram à ineficiência dos processos de avaliação, resultantes de uma incapacidade em seguir modelos de análise de perfis rigorosa, da parte dos policy-makers, baseada em rankings e listagens académicas necessárias no processo de escolha dos avaliadores.

Com efeito, o perigo da desordem da escolha, se assim quisermos chamar, está estreitamente relacionado com o segundo perigo já discutido, numa relação onde a montante temos o avaliador e a jusante o resultado da escolha do avaliador e do seu trabalho de avaliação. Trata-se de definir por que regras devemos cingir-nos aquando da escolha de um avaliador. O que é um avaliador referenciado? O que nos permite saber se o nome escolhido é adequado para a tarefa? Número de publicações? Número de anos de pesquisa naquela área específica? E qual o momento em que podemos assegurar que a pessoa escolhida cumpre os critérios mínimos para o desempenho da tarefa? Quão subjectiva é, por outro lado, essa análise curricular, e quão justa é, tendo em conta os padrões de avaliação usados na escolha de outros presumíveis avaliadores? Por outro lado, é exequível o controlo de todos os utilizadores que se auto-propõem à revista? E esse controlo deve ser desempenhado por quantos elementos do corpo editorial? Quão exequível é, do ponto de vista do gestor da revista, não perder o rasto a todos os processos, e ao mesmo tempo fazer encaminhar cada input aos elementos do corpo editorial? E que elementos do corpo editorial são esses? Quantos são? Quantos intervêm por decisão? Quão exequível é o papel de um gestor de revista, neste cenário de múltiplas exigências que vão da monitorização do status para cada artigo (revisões, re-submissões, edições, etc), ao contacto com as partes, em cada novo movimento registado na revista? E, num cenário de submissões várias, num aumento progressivo ao longo dos anos, quão limitativa pode ser a escolha dos avaliadores e qual o perigo de se recuar e flexibilizar os pressupostos que regulam a entrada de cada avaliador, por forma a aumentar o leque de escolhas capaz de manter a revista em fluxo contínuo? Estas são questões que terão de ser obrigatoriamente postas em perspectiva, durante cada processo de revisão, na medida em que é crucial, a montante, regular de forma cabal a escolha e a entrada dos avaliadores, como peças chave na definição da qualidade associada à revista. Para todos os efeitos, este é um problema característico das publicações online de largo espectro, algo que não se verifica, por exemplo, com revistas de curto alcance, de modelo tradicional, definido por um modelo 
fechado e restrito a um leque de nomes que compõem um corpo editorial e avaliativo fixos.

5) A indústria paralela lucrativa. O lado paradoxal da relação simbiótica com o indexador

O quinto problema está directamente relacionado com o primeiro problema denunciado. Num quadro de desinvestimento dos apoios a publicações de carácter periódico, e com a agudização das dificuldades dos centros de investigação que, regra geral, organizam e gerem as diferentes revistas em open access, torna-se difícil considerar as contínuas e necessárias exigências de indexadores, como um mal menor. Num contexto de racionalização de recursos, pelas razões já enunciadas, torna-se quase contraproducente entrar numa espiral de gastos cumulativos, conforme surgem novas directrizes para a aquisição de novos produtos que respondam às normas dos indexadores. Dos digital object identifiers, que muitas vezes pressupõem novos contratos para aquisição de serviços de inscrição e infraestruturas de identificação de conteúdos, passando pelo tratamento e formatação próprios dos conteúdos a registar nos indexadores, com novos programas como o Markup ou o Parser, entre imensos outros, que exigem por norma uma contratualização com um técnico exterior à revista, ou mesmo uma formação extra do responsável pela revista, muitas são as exigências que vão surgindo. Aqui, o problema maior reside na dificuldade que algumas revistas poderão sentir em manter-se em funcionamento, por duas razões essenciais: em caso de poderem dar resposta às exigências propostas, poderão colocar em causa a sustentabilidade da revista, em termos de verba necessária para o funcionamento da mesma, por mais pequena que seja; e em caso de não cumprimento com as alterações propostas, quaisquer que sejam, vêem a sua posição perante os indexadores sair prejudicada, podendo levar à sua exclusão e, ao limite, a uma certa ostracização da revista no meio e como que a uma imagem desacreditada num sector que é já por si bastante competitivo, podendo deixar de conseguir captar autores e artigos que possam garantir a periodicidade e a qualidade da revista.

6) A indústria parasitária

O sexto grande problema reside no perigo que a indústria parasitária de ciência representa. Ao longo dos últimos anos, questões como o rapto de revistas e os pedidos de aquisição de publicações, quase como se de OPAs 
lançadas se tratasse, têm sido uma constante. A título de exemplo, a revista OBS*Observatorio, propriedade do Observatório da Comunicação, tem sofrido constantes e crescentes pressões externas para libertar a revista a supostos actores que têm como fim último aglutinar o maior número de publicações periódicas possível, quase numa lógica de rapto, assumindo o ónus e responsabilidade de todas as decisões que, dali para a frente, possam vir a ser tomadas no quadro das revistas. E, como é óbvio, questões como a qualidade da revista, os direitos autorais previamente acordados, ou mesmo a lógica do interesse público, como grande bandeira do modelo de ciência aberta, ficariam irremediavelmente comprometidos num fenómeno evidente de mercantilização da coisa pública. Além do mais, a evidente ausência/degradação do modelo de financiamento para publicações deste tipo, mais não faz do que alimentar esta lógica de comportamento, no sentido em que muitas entidades responsáveis por publicações neste modelo, na ausência de qualquer tipo de financiamento, podem ver-se na iminência de decidir entre entregar a propriedade da revista, ou o descontinuar forçado dos volumes, por falta de verbas capazes de fazer face às despesas correntes relacionadas com o proofreading, edição de texto, entre outros gastos correntes.

Figura 2: exemplo de tentativa de aquisição de uma revista de publicação periódica e indexada

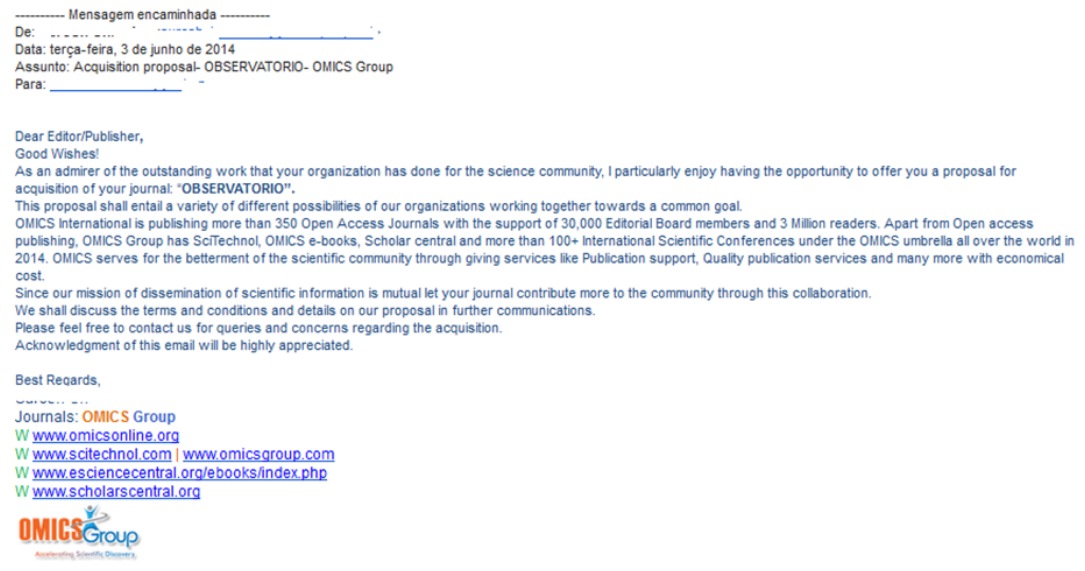


Outros perigos resultantes da ciência parasitária resultam dos jornais e publicações falsos ou clonados, capazes de baralhar um pouco a questão da oferta e o que é ou não real.

Outras questões, como a criação de corpos editoriais falsos, que de certa forma vão no sentido de legitimar a revista, dando-lhe capital simbólico, são igualmente um dos aspectos a ter em conta. Ora, é aqui que um indexador assume o seu papel mais relevante, no sentido em que permite estabelecer uma espécie de filtro que regula a entrada daquilo que é tóxico e separa o que é bom e construtivo, daquilo que é mau e destrutivo. No entanto, a própria existência e condição do indexador gera perturbação no funcionamento de uma revista, no sentido em que mexe com coisas tão primárias como a própria condição de existência da revista, ao nível da agilização dos recursos, podendo, com as exigências crescentes, asfixiar publicações e os respectivos centros de investigação que as gerem, passando a seguir um caminho que é de diferenciação, mas uma diferenciação que já não se enquadra no critério único da qualidade dos conteúdos publicados por cada revista.

Este é talvez o maior paradoxo na necessária simbiose entre a revista e o respectivo indexador. Dito de outra forma, ao mesmo tempo que um indexador, com as suas avaliações feitas às revistas que se propõem entrar nas suas bases de dados, estabelece como critério máximo de entrada a qualidade, por outro lado, e à medida que essa revista vai integrando os registos do indexador, já depois de concluído o processo de avaliação, vão sendo exigidas cada vez mais regras à sua continuação. E estas regras, que muitas vezes não vinham definidas aquando da integração da revista no referido indexador, acabam por limitar a própria reacção da revista, no sentido em que esta poderá não ter condições para dar resposta às novas exigências que vão surgindo, pondo definitivamente em causa a sua continuidade no indexador, com todos os efeitos nefastos de descredibilização que tal acontecimento acarreta. É certo que um indexador reserva para si, em qualquer momento, o direito a uma nova reavaliação baseada em novos pressupostos que venham a integrar nos seus estatutos, contudo, estas exigências crescentes pouco mais fazem do que alimentar uma indústria paralela de novos actores que entram no processo e que, em última análise, lucram com contratos paralelos sustentados na premente necessidade de novos critérios de formatação de textos, novos identificadores de conteúdo, entre outros assuntos, mesmo quando todas as revistas já incorporam códigos numéricos em identificadores (ISSN), ou mesmo quando a formatação dos 
textos já seguia anteriores critérios definidos por indexadores, critérios esses que, diga-se, até podem variar de indexador para indexador. Como combate a este tipo de indústria paralela e lucrativa, começam a surgir alguns movimentos que visam uma clarificação do modelo, no sentido em que lhe dão mais transparência. Um exemplo claro é o Centro para a Ciência Aberta, nos EUA, que foi fundando em 2013 e tem como objectivo principal contribuir para a abertura, integridade e reprodução da pesquisa científica, tirando partido de um trabalho conjunto de várias comunidades científicas que tentam produzir ferramentas e serviços válidos e gratuitos que reforcem as práticas e valores da pesquisa científica.

7) O perigo da produção em descontrolo

O modelo de ciência aberta, zeitgeist no processo de publicação científica, apesar de bem implementado e aceite em larga escala por um grande número de comunidades científicas, não goza necessariamente de uma aquiescência adquirida e universal. Existem modelos de construção de narrativas, por parte de académicos, que explanam de certa forma os grandes erros e perigos do modelo. Esta desacreditação, sustentada no entendimento dos grandes desafios relacionados com o modelo, alguns deles estando na génese da construção do próprio modelo (como a questão da informalidade), poderão, a prazo, levar a um percurso de desacreditação do modelo. Apesar de os focos principais de cepticismo não integrarem ainda as condições de falha (em alguns casos do foro logístico) inerente ao próprio modelo, como as anteriormente evidenciadas, o que é certo é que o ataque tem vindo a ser assinalável, começando desde logo pela própria noção de credibilidade. E um modelo que é visto como que passando por processos de validação redutores, comprometendo na sua génese justificativas metodológicas da neutralidade axiológica, é um modelo que, no seu percurso, irá deparar-se com resistências várias. Uma dessas resistências, ponto de base para a crítica de Cristopher Bare em "Guide to Open Science" (2014), é a confirmação de um modelo que perpetua o aumento da escala de produção da ciência, em níveis desmesurados que colocam em causa a eficaz regulação dos conteúdos produzidos e a necessária validação/verificação desses conteúdos por parte da academia. Num certo sentido, a noção de que tudo é publicável e replicável, beneficiando de um paradigma com fraquezas mais ou menos óbvias, reproduz a ideia de que é necessária maior reflexividade e o reinventar de um modelo baseado numa ciência mais refractária e na objecti- 
vidade do conhecimento, capaz de resistir ao lado destruidor de uma produção em massa, em descontrolo e em permanentemente desregulação.

Tabela 1. síntese dos pontos discutidos

Ameaças

1) O paradoxo de um sistema de indexação que promove indústrias paralelas de serviços pagos

2) Indústria parasitária

3) Insustentabilidade financeira dos centros de investigação aos quais estão associadas grande parte das publicações

\section{Pontos fracos}

1) A informalidade do modelo e o fraco comprometimento pelos facilitadores do processo

2) Processos de avaliação nãouniformizados e de validação precária

3) A vulnerabilidade à indústria do rapto e donagem de revistas

\section{Oportunidades}

1) Novos sistemas de colaboração inter-institucional, inter-disciplinar e inter-pares que reforcem a exequibilidade do modelo de Ciência Aberta e combatam o parasitismo paralelo ao modelo (ex: COS - Center for Open Science)

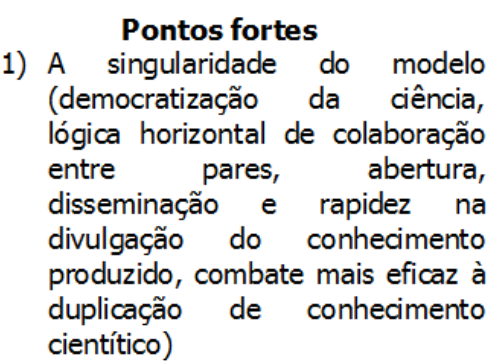

Fonte: elaboração própria

\section{Pistas para estudos futuros}

Como já sublinhado, o estudo dos desafios e perigos do modelo de ciência aberta é ainda relativamente recente, pelo que importará conhecer com mais detalhe a perspectiva de múltiplos actores no processo, sejam eles avaliadores, gestores e coordenadores editoriais de revistas, ou mesmo pessoas ligadas aos vários indexadores.

$\mathrm{O}$ argumento actual ainda se centra muito nas potencialidades e alcance do modelo e na forma como veio permitir a disseminação e divulgação de conteúdo científico necessário, mas a verdade é que não houve ainda um debate amplo ao nível das suas limitações, sendo que estas limitações, como vimos anteriormente, são muitas e afectam diversas áreas do processo de gestão das revistas. 
Neste sentido, e numa lógica exploratória, tentámos compreender, dentro de uma rede próxima de contactos, quais os principais receios e perigos percepcionados na gestão diária das revistas. Estes testemunhos foram recolhidos num contexto de troca de mensagens electrónicas, e respeitando o pedido unânime dos respondentes no necessário anonimato da divulgação das respostas. Foram colocadas três questões a pessoas associadas a indexadores e uma questão apenas a seis coordenadores de revistas editoriais em acesso aberto.

Quatro coordenadores de revista deram resposta ao pedido, ao passo que os outros dois optaram por não responder. Foram também contactadas 4 pessoas associadas aos indexadores, mas apenas uma respondeu ao pedido.

As opiniões recolhidas são elucidativas dos desafios percepcionados por intervenientes privilegiados no processo, em especial aqueles que estão directamente associados às revistas. A visão da pessoa ligada aos indexadores é talvez mais moderada e aponta para um quadro em que as revistas não deixaram ainda de cumprir com as exigências propostas, mesmo que as afirmações produzidas não invalidem propriamente o facto de estas revistas estarem a sentir mais dificuldades. Para estes respondentes, a conclusão a tirar é que as obrigações crescentes não colocaram ainda em causa o funcionamento das revistas associadas, descurando a ideia de que estas exigências têm surgido em modo cumulativo, característica que poderá assumir maiores repercussões no futuro próximo.

A questão colocada aos quatro gestores de revista foi a seguinte: Quais os principais desafios que, nas suas tarefas de gestão de revista, considera mais relevantes e que poderão pôr em causa a própria sustentabilidade da revista? (atrasos em revisões, exigências crescentes de indexadores, avaliadores registados na revista que não dão seguimento às tarefas pedidas em tempo útil; etc)

Resposta Anónimo 1: "Os principais desafios à sustentabilidade da revista, no que diz respeito às tarefas de gestão, são a capacidade de mobilizar revisores em tempo útil e também as exigências crescentes das bases de indexação. No primeiro caso, não só é difícil conseguir a colaboração de revisores como o número dos que cumprem o pedido na data estipulada é muito reduzido, comprometendo a pontualidade da publicação. Penso que isso tem a ver com a sobrecarga a que estão su- 
jeitos muitos investigadores/docentes mas também a algum fechamento de classe, havendo competição em vez de cooperação entre profissionais da mesma área. No segundo caso, dou este exemplo: a publicação de um número, quando todos os elementos estão prontos e revistos, é coisa para demorar uma manhã de trabalho; a preparação dos mesmos conteúdos para os formatos exigidos por algumas bases é trabalho para uma semana, com sucessivas revisões e alterações. É um bocadinho a subversão do objectivo destas bases, que deveriam promover a visibilidade dos estudos publicados em vez de atolarem quem trabalha na divulgação científica em tarefas morosas, tecnicamente inflexíveis."

Resposta Anónimo 2: "A revista X, da qual sou coordenadora editorial, tem tido dificuldade em se indexar convenientemente devido à sua falta de periodicidade e isto deve-se a dois fatores: os autores e os revisores não cumprem os prazos nem as regras, alegando sempre a falta de tempo como se nós, editores, não tivéssemos também outras atividades."

Resposta Anónimo 3, relativamente à dificuldade em obter revisões em tempo útil: "É difícil e podia ser tão mais fácil se por vezes dissessem que não podem. Vale-nos a compreensão mútua e a colaboração de outros colegas, que compensam as impossibilidades e imprevistos."

Resposta Anónimo 4: While $Y^{1}$ journals are not in jeopardy of their sustainability, certainly one of the challenges are timely reviews."

As três perguntas colocadas a uma pessoa que desempenha trabalho num indexador, foram as seguintes:

Pergunta 1: Considera que as crescentes exigências por parte de alguns indexadores, poderão levar à exclusão de revistas de qualidade reconhecida, que, por uma questão de falta de recursos, não têm como fazer face a despesas extra decorrentes de novos requisitos e imposições?

Pergunta 2: Considera que já podemos referir com alguma propriedade que existe uma indústria paralela lucrativa a beneficiar da simbiose necessária entre revista e indexador?

Pergunta 3: Perante o crescimento da indústria parasitária (rapto de revistas, clonagem de revistas, clonagem de corpos editoriais, etc), quais pensa que serão as principais estratégias de um indexador para fazer face ao problema,

1. Y diz respeito ao nome de uma revista científica internacional em open access, com sede nos EUA. Para efeitos de anonimato, também a referência exacta à dita revista foi retirada. 
no curto prazo? Devem os indexadores intervir numa clarificação e ataque ao problema, junto dos incumpridores, ou este é apenas um problema que resulta da falta de regulação eficaz neste sector, não cabendo ao indexador a resolução deste tipo de problemas?

Resposta Anónimo 1: "A única coisa que posso transmitir é a nossa experiência relativamente à primeira questão. Apesar de termos aumentado as exigências, não houve até à data nenhuma revista que desistisse da $\mathrm{X}^{2}$ por incapacidade de dar resposta. Julgo que as revistas de qualidade reconhecida encontraram estratégias para se adaptarem às novas exigências. Por outro lado, revistas de menor qualidade e menos profissionalizadas terão mais dificuldade em conseguir a sua indexação em bases de dados."

\section{Referências bibliográficas}

Bare, C. (2014). The guide to Open Science. Disponível em: www.fosteropenscience.eu

Benkler, Y. (2006). The Wealth of Networks - How Social Production Transforms Markets and Freedom. Disponível em: http://hosamred.googlepages.com

Castells, M. (2002). A Era da Informação: economia, sociedade e cultura, Vol.1: A Sociedade em Rede. Lisboa: Fundação Calouste Gulbenkian.

Casati, F. et al (2006). Publish and perish: why the current publication and review model is killing research and wasting your money. Disponível em: http://eprints.biblio.unitn.it

Cardoso, G. \& Jacobetty, P. (2010). O que significa Open Science?. Disponível em: www.lini-research.org

Cribb, J. \& Sari, T. (2010). Open Science: Sharing knowledge in the global century. Australia: CSIRO Publishing.

Jankowski, N.W. (2007). Exploring e-science: An introduction. Journal of Computer-Mediated Communication, 12(2): 549-562. Disponível em: http://jcmc.indiana.edu

2. X diz respeito ao nome de um indexador/colecção de revistas e artigos científicos. Para efeitos de anonimato, também a referência exacta ao dito indexador foi retirada. 
Nentwich, M. (2005). Cyberscience: Modelling ICT-induced changes of the scholarly communication system. Information, Communication \& Society, 8(4): 542-560.

Priem, J. \& Hemminger, B. (2012). Decoupling the scholarly journal. Frontiers Computational Neuroscience, 6(19): 1-13. Disponível em: http://journal.frontiersin.org

Rodrigues, M.J. et al (2009). Europe, Globalization and The Lisbon Agenda. MA, USA: Edward Elgar.

The EU Framework Programme for Research and Innovation (Horizonte 2020): http://ec.europa.eu 


\title{
O cientista, o jornalista e o assessor. Uma análise dos embates, dos limites e das possibilidades de construção de um possível diálogo
}

\author{
Boanerges Balbino Lopes Filho \& Wedencley Alves \\ Universidade Federal de Juiz de Fora \\ E-mail: bblopes@globo.com/ wedencley@gmail.com
}

\begin{abstract}
Resumo
Os processos de comunicação são atualmente pensados, nos estudos de mídia, como espaços de disputas. Envolvem mediações comunicacionais a partir de demandas individuais e de grupos, com a utilização e apoio das tecnologias e redes, cada vez mais autônomas em relação aos centros originários. Os diversos atores envolvidos nas arenas informacionais se relacionam produzindo avanços e recuos, fricções e alianças, acordos e desacordos, hegemonias e contra-hegemonias discursivas, polarizando assim o denominado poder simbólico. Assim, organizações - empresas, entidades, associações, governos etc. - precisam usar este espaço para tornar visíveis suas ações, ao mesmo tempo em que buscam a legiti-

midade junto à imprensa. Neste artigo, tratamos da relação entre imprensa, pesquisadores e instituições científicas. Se jornalistas reclamam da pouca disposição dos cientistas em repassar-lhes as informações solicitadas, pesquisadores desconfiam do que será publicado em seus nomes. Se jornalistas ou cientistas estão certos em suas queixas e desconfianças, nunca saberemos. Mas uma questão pode nos ajudar a discutir o problema: "As estratégias de comunicação praticadas pelas organizações - especialmente instituições de saúde - têm contribuído de alguma forma para uma boa divulgação científica e incrementado o aumento da qualidade de vida da sociedade"?
\end{abstract}

Palavras-Chave: Comunicação; ciência, divulgação; relacionamento; diálogo.

\begin{abstract}
The communication process is thought at present, in media studies, as place of disrequirements with the use and support putes. It involves individual and group gly independent from its original centers.
\end{abstract}


The relationship among various actors makes, at informational arenas, progresses and retreats, frictions and alliances, agreements and disagreements, discursive hegemony and counter-hegemony, polarizing the so-called symbolic power. Thus, organizations - companies, institutions, associations, governments etc. need to use this place to make visible their actions, while they search legitimation on the media. In this paper, our aim is to understand the relationship among the press, researchers and scientific insti- tutions. While the journalists complain about the unwillingness of scientists to pass them the information required, researchers are wary of what will be published in their names. We shall never know if journalists or scientists are right in their complaints or distrust, but a question helps us to discuss the subject: "Communication strategies practiced by organizations - especially, heath institutions - have contributed to a good popular science, and magnifying and increasing society's quality of life?"

Keywords: Communication; science, disclosure; relationship; dialogue.

\title{
Introdução
}

\begin{abstract}
relação entre imprensa e instituições de saúde suscita questionamentos A tanto de um lado quanto de outro. Jornalistas reclamam da pouca disposição dos profissionais de saúde em atender os meios e repassar informações mais amplas quando solicitadas. Médicos, pesquisadores, entre outros, desconfiam do que será publicado em seu nome. Independentemente dos dois lados terem ou não razão em suas queixas, uma terceira indagação, menos corporativa e mais afinada com os anseios da população, deve ser feita: "as estratégias de comunicação utilizadas pelas diversas empresas e instituições que atuam nas duas áreas têm contribuído de alguma forma para o aumento da qualidade de vida do cidadão?
\end{abstract}

\section{Referências}

Responder a esta questão e mais algumas outras deve estar na agenda de quem está preocupado efetivamente com as necessidades da sociedade na área de saúde. É evidente que não podemos negar as dificuldades de superação da distância - de estilos, de interesses, de rotinas de trabalho, de visões de mundo - entre os profissionais, distâncias que foram e são alimentadas visivelmente 
O cientista, o jornalista e o assessor. Uma análise dos embates, dos limites e das possibilidades de construção de um possível diálogo

a cada dia, contribuindo para aumentar o sofrimento e as dificuldades da população brasileira. Ou seja: tanto o campo da saúde, quanto o campo da mídia estão em débito com a sociedade.

E as dívidas são altas. Pesquisa realizada pelo instituto Datafolha mostrou que, para um grande contingente populacional, o principal problema das grandes cidades brasileiras é justamente o estado permanente de crise na saúde pública. No final de 2008, 28\% dos entrevistados apontavam o setor como o mais preocupante. No início de 2011, o número foi a $31 \%$. E, em janeiro, o índice de preocupação chegaria a 39\%. Ainda que o instituto de pesquisa jogue claramente a culpa num só agente, os governos, é claro que algo está errado também na cobertura de imprensa, como veremos mais adiante.

Três são as questões levantadas neste artigo, e três são as tentativas de responder a elas: quais os embates mais freqüentes entre imprensa e instituições de saúde? Quais os limites tanto discursivos quanto institucionais que há entre a cobertura jornalística e as práticas da saúde? Qual o perfil mais apropriado do assessor de comunicação e de imprensa, profissional que poderia fazer a mediação mais capacitada entre uns e outros?

\section{Território de embates}

A preocupação da população, demonstrada pelo instituto Datafolha, não está dissociada da realidade. É que, apesar de alguma evolução, as estatísticas ainda acentuam aspectos dramáticos da saúde pública no Brasil ${ }^{1}$. Infelizmente os dados desse "diagnóstico" parcial quando divulgados - em raros momentos - são fragmentados pelos principais jornais, revistas, rádios e tevês. As coberturas nesta área acabam em editorias diferentes. Textos dispersos, além de manchetes, títulos, legendas e fotos alarmantes reforçam preconceitos e mitos. As reações vão da perplexidade ao pânico. Mas de concreto, pouco se resolve.

1. Só para ficar no exemplo da saúde básica. Embora tenha passado a integrar o grupo de países com alto Índice de Desenvolvimento Humano (IDH), o país ainda convive com números muito preocupantes: em relação, ao tratamento de esgoto, por exemplo, $57 \%$ da população brasileira ainda não têm acesso a este serviço, e do que é coletado só 1/3 é tratado, segundo o levantamento disponibilizado pelo Sistema Nacional de Informações sobre Saneamento, um acompanhamento anual realizado pelo Ministério das Cidades. Um número tão alto de desassistidos não terá outra consequência se não a de provocar uma sobrecarga insuportável sobre o atendimento público de saúde. 
Por outro lado, a maioria dos governantes e administradores da saúde pública, por motivos políticos, e profissionais de saúde, por zelo com relação aos seus nomes, sente-se desconfortável em relação à cobertura quase sempre alarmista da imprensa. Exemplos não faltam: em 2010, uma pesquisa para a Faculdade de Saúde Pública da Universidade de São Paulo mostrou que a epidemia de febre amarela foi "construída" pela imprensa (Malinverni, 2011); outra, desta vez, na Fundação Oswaldo Cruz, demonstrou que o intertexto político prevaleceu na cobertura sobre a H1N1 (Neves, 2012).

Seja exagerando, seja atribuindo sentidos que têm pouco a ver com esclarecimentos à população, a imprensa acaba conquistando a desconfiança, não somente dos governos, mas também dos profissionais do campo da saúde. $\mathrm{O}$ resultado é que os administradores e os profissionais da saúde pública, por motivos políticos ou de auto-preservação, acabam também estimulando, com seu distanciamento, a criação de uma narrativa jornalística, por vezes voltada mais à especulação e menos á informação sobre a realidade. Se as fontes se preservam, é a informação que sai em prejuízo.

E nesse caso onde entra o interesse público? Acaba perdido num emaranhado de disputa de poder e barganhas. Idealmente, seria preciso estabelecer uma correta parceria entre profissionais de saúde e de imprensa, melhorando as práticas de comunicação entre ambos e forçando o poder público a criar novos mecanismos capazes de imprimir-lhe clareza indiscutível que se contraponha ao clientelismo e à utilização do estado em benefício de interesses cartoriais.

Mas este "ideal" parece se deparar com obstáculos maiores que os jogos de projeção imaginária que uns sustentam contra outros (jornalistas, vistos como "deturpadores e sensacionalistas" para os responsáveis pela saúde; estes, como "dissimulando informações", para os jornalistas). Estes obstáculos parecem remeter a diferenças discursivas e institucionais, se não intransponíveis, pelo menos difíceis de serem superadas, se não se buscar uma compreensão do funcionamento das instituições e dos discursos do campo da mídia e do campo da saúde.

Neste fogo cruzado, é justamente o profissional de comunicação especializado em saúde, que talvez pudesse sanar tanta diferença. 
O cientista, o jornalista e o assessor. Uma análise dos embates, dos limites e das possibilidades de construção de um possível diálogo

\section{Limites e possibilidades: questões institucionais e discursivas}

Comecemos com algumas possibilidades, a partir do fenômeno da midiatização das esferas sociais.

O processo de publicização pela mídia dos discursos sociais não pode ser visto somente com uma incorporação in natura dos sentidos circulantes na sociedade, mas um reprocessamento destes discursos, o que provoca deslocamentos a serem considerados por quem se debruçar sobre as questões da educação para a saúde, e que dedique especial atenção ao papel da mídia.

Isto não reafirma qualquer intenção, muito comum no campo das comunicações, de acreditar que sentidos sociais originam-se na imprensa ou na mídia em geral. Parte-se do pressuposto de que há um contínuo processo de vocalização e silenciamentos de discursos já presentes na sociedade, mas cujo processo é, devido às formas de textualização propriamente midiáticas, o de redefinição lógica destes discursos.

Isso é facilmente visto nas discussões acerca da espetacularização dos fatos relacionados à saúde, um fenômeno próprio do sistema de mídias na contemporaneidade. Ao se autorizar, por exemplo, como meio de divulgação científica em saúde, a mídia contribui necessariamente para alterar e não simplesmente promover a imagem do campo da saúde. Ora, se a imagem do que seja a saúde muda conforme as circunstâncias históricas e as expectativas sócio-culturais, é pelo menos razoável deduzir que tamanha interferência vai levar a conseqüências ainda não dimensionadas, mas de antemão bastante importantes para como a sociedade compreende a saúde numa sociedade midiatizada.

Estamos falando aqui da midiatização simétrica do campo da saúde: sua passagem pela mídia ao mundo dos comuns, mas também sua própria estruturação midiática. Isso faz com que a própria medicina, por exemplo, passe por uma forte adesão a suportes de mídia - vídeo-cirugias, uso das redes para transmissão de conferências, exames, procedimentos terapêuticos, blogs escritos por médicos.

É preciso compreender, por exemplo, que o leitor atual, ao se deparar com a midiatização do campo da saúde, e com uma medicina midiatizada, tende a valorizar aquilo que atende à linguagem e discursividade própria aos meios de comunicação. O que, por efeito, vai resultar no fato de que os processos de 
identificação do sujeito com a medicina - e, portanto, com as informações dela procedentes - podem estar atravessadas por elementos da cultura dos media.

O maior sintoma desses atravessamentos é o fato de que coberturas sistemáticas sobre um assunto de saúde em especial, acaba movendo a agenda das preocupações da sociedade. Personagens da vida pública acometidas pelo câncer produzem um maior interesse pela doença, assim como os perfis magérrimos de mulheres modelos podem levar a gerações de menina a rejeitarem uma alimentação adequada.

Ao mesmo tempo, o próprio processo de midiatização, pelos deslocamentos de sentido supracitados, pode trazer problemas para a apreensão do conhecimento sobre a saúde por parte da população em geral: como a busca pela informação que provoque mais comoção e mais atração e o esquecimento de problemas mais básicos, mas que têm consequiências profundas sobre a saúde da sociedade, como é o caso das carências do saneamento básico - que não dão notícia nem votos.

A midiatização da sociedade, estabelecendo um continuum entre a linguagem dos meios de comunicação e as ações institucionais, portanto, podem contribuir para estreitar as distâncias entre a compreensão do público em geral e dos cientistas. Isto é uma possibilidade positiva. Mas, ao mesmo, tempo, se não vista com responsabilidade pela sociedade, pode simplesmente transformar a ciência num picadeiro, para notícias sensacionais, e práticas espetaculares.

Abre-se espaço neste momento para a comunicação institucional, como um lugar de elaboração e reelaboração dos sentidos midiatizados no campo da saúde, uma grande possibilidade de intervenção positiva. Idealmente, a atividade seria exercida ou gerida por um profissional que conhecesse muito bem a linguagem própria da mídia e os meandros complexos de um campo como o da saúde. Um profissional que conseguiria, dado o processo de midiatização social, explorar as possibilidades e evitar os riscos postos por este mesmo processo.

Mais que mediador, ele poderia ser aquele profissional capaz de esclarecer a própria imprensa sobre os riscos sociais de sua cobertura. Exemplos podem ser citados neste momento: as notícias divulgadas sobre a dengue em algumas regiões do país abalaram a indústria do turismo provocando demissões de profissionais da área, devido ao tratamento inadequado das informações. $\mathrm{E}$ os retratos que os meios de comunicação apresentam sobre os pacientes in- 
O cientista, o jornalista e o assessor. Uma análise dos embates, dos limites e das possibilidades de construção de um possível diálogo

ternos em hospitais psiquiátricos em geral são extremamente negativos, não contribuindo em nada para a modificação do quadro.

Ou seja, prejuízos sociais ou individuais causados por falta de preparo profissional e responsabilidade institucional da imprensa, mas que, por outro lado, receberam e recebem muito pouca atenção por parte de especialistas, por administradores e, é claro, pelo poder público.

\section{A mediação entre a instituição de saúde e a imprensa}

Se pelo lado da Imprensa, as posturas não têm sido muito satisfatórias, no denominado lado de cá, ou seja, os representantes da área de saúde, as falhas também são muitas. E quem acaba no meio deste fogo cruzado é justamente o assessor de comunicação social. Quando chamado a intervir, defronta-se normalmente com uma situação já definida - geralmente de crise - e com determinações prontas: 'precisamos é de uma campanha', 'temos que responder à Imprensa desta ou daquela forma' ou 'vamos organizar um evento' é o que ouvimos com tanta frequiência.

É uma situação imposta que normalmente limita-se a ações tópicas e localizadas, o que normalmente denominamos como "apagar incêndios". O ex-diretor de Comunicação Social da Secretaria Estadual de Saúde de Minas Gerais, João Paulo Pinto da Cunha, deixou registrado, num artigo sobre o assunto, já em 1994, no jornal do Radis (Fiocruz), o seguinte desabafo:

Geralmente o responsável pela comunicação recebe uma encomenda definida em termos de público, estratégia e mensagem. Cabe apenas executar. Esta concepção mostra um desrespeito duplo, pela comunicação e pelo profissional. Ainda que não seja uma ciência, a comunicação é, no mínimo, uma técnica com um grande e sofisticado arsenal de intervenção na realidade e no imaginário das pessoas e dos grupos. O comunicador, por sua vez, deve dominar os elementos que lhe deem conhecimento das linguagens, da circulação das mensagens e do mundo de significações dos diferentes públicos. Se o pedido de uma campanha já chega embalado, carimbado e com destino certo, perde-se o potencial da comunicação e do comunicador. (Cunha, 1994)

Quanto mais nos aprofundamos nos assuntos que envolvem a área de saúde, as crises se sucedem: financiamentos, regulamentações das políticas, 
organização de modelos e muitos outros problemas. É neste contexto que a comunicação cada vez mais tem uma enorme contribuição a dar. Sua absorção pelas políticas públicas é uma necessidade premente. E sua concepção deve trilhar por outros caminhos, mais abrangentes.

Os serviços de saúde possuem características próprias que normalmente os diferenciam de outras organizações. Os usuários nem sempre têm informações para avaliar e definir suas necessidades e as maneiras mais adequadas de atendê-las. Os resultados também são de difícil mensuração, sobretudo nos casos mais complexos.

Além disso, a organização dos serviços tem uma dimensão ética e moral bem própria com situações delicadas da biomédica, envolvendo sigilo, direito do usuário à informação e mais uma ampla estrutura administrativa e alocação atípica de recursos. Acreditar que tanto profissionais de imprensa quanto de saúde poderiam entender detalhadamente todo este processo é criar uma falsa expectativa. Assim também como é falso definir o espaço de atuação do comunicador da área de saúde somente pelos contatos com a grande imprensa em casos determinados ou com a dinâmica rotineira de produção de clippings e outros instrumentos utilizados dentro de um setor de assessoria de comunicação. Insistir nestas práticas é deixar de entender o seu verdadeiro papel e limitar o seu potencial.

Os objetivos de uma assessoria de comunicação são e devem ser mais ambiciosos: sempre em mão dupla, identificando os anseios da 'população com informações objetivas, precisas e claras e proporcionando cada vez mais a multiplicidade de canais para levar mensagens adequadas e possibilitar que toda a complexidade que absorve a área de saúde seja progressivamente desnudada pelos cidadãos. E, no sentido inverso, apresentar os meandros que cercam jornais, revistas, rádios e tevês para os profissionais de saúde, no caso a clientela interna.

Algumas experiências em determinadas realidades regionais hoje são alentadoras e comprovam que é possível avançar através de espaços diferenciados de atuação. Por exemplo: O projeto desenvolvido pela Universidade Federal de Uberlândia - MG - e o hospital universitário local através da criação de manuais com dicas essenciais para o esclarecimento das atividades de jornalistas e profissionais de saúde tem resultado em novas formas de entendimento entre os setores. 
O cientista, o jornalista e o assessor. Uma análise dos embates, dos limites e das possibilidades de construção de um possível diálogo

Outro exemplo: a elaboração da cartilha ilustrada, pelo Departamento de Comunicação da Universidade Federal de São Paulo, Unifesp, que aborda de maneira divertida a complicada relação dos médicos com a imprensa. A criação de vários serviços de atendimento ao usuário nos setores de saúde das secretarias, postos e hospitais é uma demonstração clara que o cidadão "redescobriu"seus direitos e tem buscado 'todos os caminhos possíveis para interagir com as instituições e empresas.

Infelizmente são casos isolados, mas que apontam para possibilidades de uma mediação eficaz e consequente para a saúde coletiva.

\section{Considerações finais}

Através de mediações conscientes, é possível trilhar novos caminhos para um dos dilemas apresentados pela professora Cremilda Medina, para quem a ciência e as condições sociais do final do século estão diante de um grande dilema: reafirmar o paradigma cientificista ou exigir uma nova mentalidade de saber, que é justamente o que a autora defende. Esta "nova mentalidade' apontaria para uma "ruptura, onde os especialistas precisam reencontrar os elos perdidos, entre eles e as múltiplas sabedorias para, juntos, darem outras respostas aos impasses históricos"que se apresentam hoje.

Infelizmente, os agentes que ainda hoje detêm posições de mando e controlam grande parte das informações nas principais instituições do país, na prática, ainda estão longe de entenderem o que Medina caracteriza como a experimentação de "atos epistemológicos", que apontariam para uma aproximação do especialista e do detentor do saber daquele homem mais comum, para juntos encontrarem soluções para os problemas que os afetam.

Medina confia que uma "pesquisa de linguagem transformadora" poderia levar a esta aproximação, e aqui enfatizamos que a comunicação tem um amplo papel a desempenhar neste processo. È o que de certa forma já se concretiza em algumas situações da prática profissional, como citadas neste artigo. Mesmo que esporádicas, mas de todo, extremamente enriquecedoras.

O comunicador da saúde deve interagir, buscar a via de mão dupla, num processo abrangente de relações, estabelecer um processo dialógico entre ciência, imprensa e sociedade. Esse "artesão criativo do diálogo transformador da ciência e do saber cotidiano"talvez possa reverter a opinião um tanto pessimista de boa parte de nossa academia. 
É o momento do repensar o coletivo, onde instituições que lidam com o saber e reflexões em seus espaços estabeleçam uma aproximação definitiva com as organizações jornalísticas, através de projetos concretos e não com complexas elucubrações delirantes. É hora também de as empresas jornalísticas atuarem na promoção da saúde, em vez de assumirem apenas a posição de agentes de acusação e de denúncia. É hora, enfim, de promover a formação de profissionais de comunicação capazes de fazer esta mediação para o bem social.

Precisamos transpor de simples registros de verdade para verdadeiros registros de justiça.

\section{Referências}

Alves, W. (2011). O espetáculo do saber: Corpos, Imagens e Materialidades Médicas. Revista EPOS, (4). Rio de Janeiro: IMS.

Araújo, I. \& Cardoso, J.M. (2007). Comunicação e Saúde. Col. Temas do Saber. Rio de Janeiro: Fiocruz.

Bueno, W.C. (1995). Comunicação na Era da Qualidade. São Paulo: Contexto Comunicação e Pesquisa/Unimed Amparo.

Bueno, W.C. (1996). Comunicação para a saúde: uma experiência brasileira. São Paulo: Ed. Plêiade/Unimed Amparo.

CRESCE a rejeição a governos na saúde, diz Datafolha. São Paulo: Portal UOL, disponível em www1.folha.uol.com.br, acesso em 31/01/2012.

Cunha, J.P. (1994). Um arsenal usado de forma conservadora. Revista Radis. Rio de Janeiro: Fiocruz.

Hansen, J.H. (2004). Como entender a saúde na comunicação?. São Paulo: Paulus.

Lopes, B. \& Nascimento, J. (1996). Saúde e imprensa: o público que se dane. Rio de Janeiro: Mauad.

Luiz, O.C. (2006). Ciência e risco à saúde nos jornais diários. SP: Anablume.

Malinverni, C. (2011). Epidemia Midiática: Um estudo sobre a construção de sentidos na cobertura da Folha de S.Paulo sobre a febre amarela, no verão de 2007-2008. Dissertação de Mestrado. São Paulo: USP. 
O cientista, o jornalista e o assessor. Uma análise dos embates, dos limites e das possibilidades de construção de um possível diálogo

Medina, C. (1994). Epistemologia Pragmática e Saber Plural. Coleção Saber Plural: Novo Pacto da Ciência, 3. São Paulo: ECA/USP/ CNPq.

Medina, C. (2003). A arte de tecer o presente, narrativa e cotidiano. SP: Summus editorial.

Neves, T. (2012). HIN1 e Produção de Sentidos na Mídia: A epidemia de 2009 nas páginas de O Globo, Extra e Expresso. Dissertação de Mestrado. Rio de Janeiro: Fiocruz.

Paes da Silva, M.J. (2002). Comunicação tem remédio: A comunicação nas relações interpessoais de saúde. São Paulo: Edições Loyola.

Paulino, F.O. (org). (2009). Comunicação e Saúde. Brasília: Casa das Musas.

RelatóRio anual do Sistema Nacional de Informações sobre Saneamento. Brasília: Ministério das Cidades. Disponível em www.snis.gov.br. Acesso em 31/01/2012.

Rothberg, D. (2011). Jornalismo Público. SP: Editora Unesp.

Tabakman, R. (2013). A saúde na mídia - Medicina para jornalistas, jornalismo para médicos. SP: Summus editorial. 
$\bigoplus$

$\bigoplus$

$\oplus$ 


\title{
És o que podias ter sido? Sobre como os jovens contemporâneos são convocados ao inverossímil
}

\author{
Lina Raquel Marinho \& Lana Veras \\ Universidade da Beira Interior / Universidade do Estado do Rio de Janeiro \\ E-mail: Lina_usa76@hotmail.com/Lanaveras@hotmail.com
}

\begin{abstract}
Resumo
Construiremos uma análise crítica e conjectural a partir de um estudo bibliográfico, acerca do capitalismo contemporâneo, seus mecanismos de violência socioeconômica e seu caráter predatório. Partiremos da análise de duas peças publicitárias veiculadas na cidade de Lisboa, que primeiro responsabilizam seus jovens e depois os convocam ao inverossímil das possibilidades meritocráticas individuais seus jovens diante da sociedade capitalista e suas conquistas e realizações. Estes jovens são parte de uma lógica cuja gestão da informação e do conhecimento está também a serviço da sociedade do valor que transforma todas as esferas da vida em mercadoria,

dores, e na qual os produtos, são os únicos meios de se assegurar a projeção e mediação/realização da própria subjetividade no mundo. Autores como Anselm Jappe, filósofo alemão e estudioso de Debord, e Robert Kurz, também filósofo e ensaísta alemão membro do grupo de estudos e pesquisa Krisis, entendem que são as contradições e limitações internas do capitalismo, agudizadas em sua fase atual ou mais tardia de produtividade, liberação de mão de obra, queda no valor gerado versus necessidade permanente de sempre gerar mais valor e finitude dos recursos planetários, que tornam esta lógica cada vez mais violenta e cuja própria ontologia passa a ser a barbárie.
\end{abstract} seus indivíduos em invariáveis consumi-

Palavras-chave: Capitalismo; meritocracia; mercantilização; sociedade do valor e informação.

\begin{abstract}
We are going to build a critical and conjectural analysis based on a theoretical study towards the contemporary capita-

lism, its social and economical mechanisms of violence and its predatory character. Considering from the exam of
\end{abstract}


two advertising pieces promoted in Lisbon that first charge their youth and then after call upon individual unlikely meritocratic possibilities, their youth once facing the capitalistic society and their conquers and acquirements. These young are part of a logic in which the information and knowledge management is also in service of the so called valuing society that is able to transform all life dimensions into merchandise, all individuals in inescapable consumers, and in which the products, are the only way to assure the projection and mediation/accomplishment of the own subjectivity in the world. Authors as Anselm
Jappe, a German philosopher and a Debord researcher, and Robert Kurz, also a German philosopher and essayist, member of the researching group: Krisis, they understand that the internal contradictions and limitations of the capitalism itself, taken into extreme, sharpened in its most actual or later producing phase, causing labour dispense, fall of the value generated versus the permanent necessity of always generating more value and the planetary finiteness of the sources, that these transform the logic in an each time more violent logic, where its own ontology becomes the barbarism.

Key-words: Capitalism; meritocracy; commodification; valuing society and information.

\section{Uma convocação, um discurso, uma ação}

TÁ está escuro quando Pedro entra na estação de metrô, ainda é inverno em Lisboa e ele se apressa para conseguir entrar no último vagão. Próxima estação: Rossio.

Senta-se em frente à Joana e, devido à calefação, pode tirar o seu casaco mais pesado. Fazer entregas de moto a essa época fria deve ser muito desgastante, pensa Joana sobre o trabalho de Pedro, ao ler seu crachá de uma rede de fast-food com o cargo "Entregador". Pedro fica um pouco constrangido quando percebe que Joana lê o seu crachá, e fica a pensar de onde viria moça tão "gira", com altivez de princesa? Próxima estação: Restauradores.

Joana vinha do seu plantão como operadora de telemarketing, em silêncio pensava sobre suas metas não cumpridas naquele dia extenuante de trabalho, metas de vendas de seguros. Próxima estação: Avenida.

Muitas pessoas entram no vagão a cada estação, afora os turistas com sacolas e sorrisos, a maioria retorna para casa após um dia de trabalho, ou de busca por ele, e o metrô se demora um pouco mais na estação da Avenida da 
És o que podias ter sido? Sobre como os jovens contemporâneos são convocados ao inverossímil

Liberdade. Pedro olha pela janela da sua direita e vê uma peça publicitária que chama muito sua atenção. Joana olha pela janela da sua direita e vê uma peça publicitária que chama muito sua atenção.

Aquela propaganda parece falar diretamente com eles e os inquire: "És o que podias ter sido?"

A imagem publicitária que captura Pedro (figura 1), um grande capacete híbrido metade astronauta com a inscrição "As tuas ambições" e metade entregador de pizza com a inscrição "As tuas habilitações", não deixa nenhuma dúvida: ele fracassou.

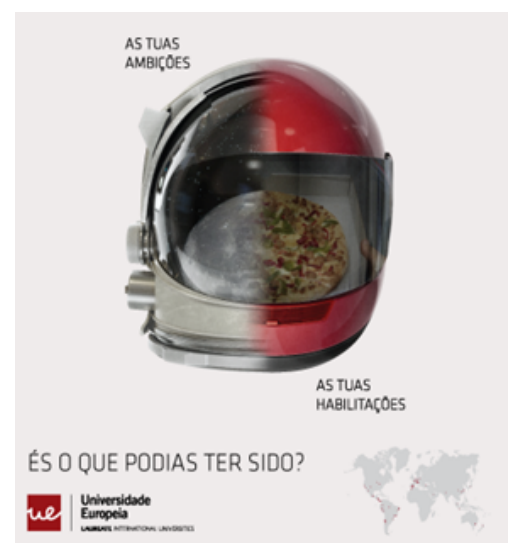

Figura 1. Publicidade veiculada no metro de Lisboa no primeiro semestre de 2015

A imagem publicitária que captura Joana (Figura 2), uma graciosa coroa de princesa, ao lado da legenda "As tuas ambições", logo sofre uma mutação e, ao lado de "As tuas habilitações" o que é mostrado a Joana é um fone de operadora de telemarketing. Não há nenhuma dúvida sobre seu fracasso: a responsabilidade por ele é dela. Próxima estação: Marquês de Pombal. 


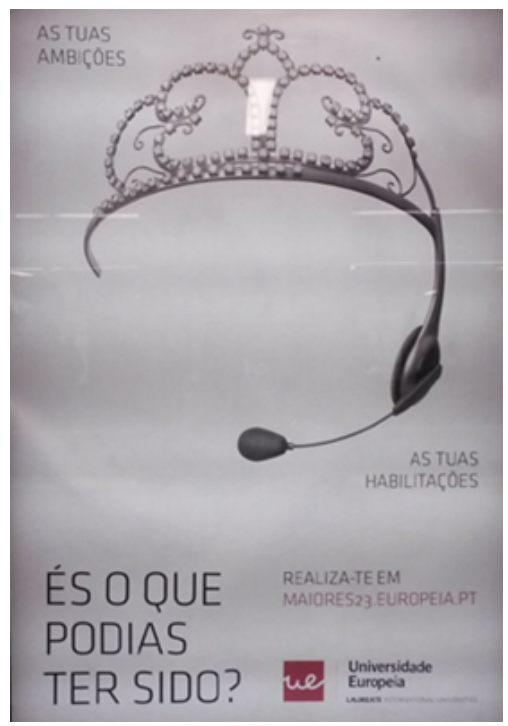

Figura 2. Publicidade veiculada no metro de Lisboa no primeiro semestre de 2015

Pedro olha para a bota de Joana, que, por sua vez, fita a mochila de Pedro, no chão. Próxima estação: Parque. És o que podias ter sido? Próxima estação: São Sebastião. És o que podias ter sido? Próxima estação: Praça de Espanha. És o que podias ter sido? Próxima estação: Jardim Zoológico. És o que podias ter sido? Próxima estação: Laranjeiras...

Os pensamentos de Pedro somente são interrompidos quando da risada do senhor que lê um livro, sentado ao seu lado. Quase que discretamente, Pedro consegue ler uma parte da História:

"De como o Barão salva-se a si mesmo e a seu cavalo puxando-se pela trança do cabelo para fora do lamaçal."

Diz a fábula:

"De outra feita eu quis pular sobre um lamaçal, que de primeiro não me pareceu tão largo. No meio do salto, no entanto, me dei conta de seu verdadeiro tamanho. Suspenso no ar, me virei, e voltei para donde saíra, a fim de tomar maior impulso. Entretanto, voltei a pular muito 
És o que podias ter sido? Sobre como os jovens contemporâneos são convocados ao inverossímil

pouco pela segunda vez e caí no lamaçal, afundando até o pescoço, não muito distante da margem oposta. Eu estaria irremediavelmente perdido naquela situação, não tivesse a força do meu próprio braço me agarrando pela minha própria trança e me puxado, junto com meu cavalo, que abracei com força entre meus joelhos, para fora dali."

Joana, por sua vez, conseguiu ler o título do livro: "As surpreendentes aventuras do Barão de Munchausen".

Publicado inicialmente em 1895, o texto de Rudolph Erich Raspe divulgou histórias atribuídas ao citado Barão, também conhecido pela alcunha de o maior mentiroso de todos os tempos. A obra tem novas edições ainda hoje e continua cativando leitores com seu conteúdo adjetivado comumente de: fantástico, inverossímil, impossível, fantasioso, inexequível, infactível, extraordinário ou impraticável.

Joana e Pedro desembarcam do metro e seguem rumo às suas casas, às suas rotina possíveis. Mas carregam consigo o fardo que o encontro com as descritas propagandas, de uma rede mundial de universidades particulares, os deixou.

A que aquelas peças publicitárias convocavam Joana e Pedro?

Sim, elas demandavam deles um ato fantástico, inverossímil, impossível, fantasioso, inexequível, infactível, extraordinário ou impraticável. Na volta de um dia de trabalho precarizado o que aqueles jovens recebiam era uma cobrança para que eles próprios se puxassem do pântano onde estavam, se erguessem pelos próprios cabelos! E mais, eram cobrados a salvar a eles próprios e, ainda, a seus cavalos.

Parece-nos incrível que uma solução que tenha causado riso a tantos leitores das "Surpreendentes aventuras do Barão de Munchausen", pela sua implausibilidade, possa ser imperativamente solicitada a esses jovens. Eles passam da ambição, também construída socioculturalmente, de ser princesa ou astronauta, à realidade de inglórios trabalhadores. Além de serem, violentamente, colocados no papel de únicos responsáveis por seu afundamento na lama do pântano.

Não há, no percurso de Pedro e Joana, uma voz que lhes leve a refletir, a perguntar: "-Porque há pântano? -Porque sou eu que estou a afundar nele enquanto outros estão em terra firme e declaram, em tom de obviedade, "-Ele poderia se puxar pelo cabelo se quisesse, se se esforçasse... veja só o exemplo do Barão, ele lutou, conseguiu por ele mesmo, por seus próprios méritos!!”. 
Assim, sem nenhuma relação com o "mundo como ele é", onde os corpos ainda estão submetidos à lei da gravidade, ao contexto social, a alternativa imposta de "puxar-se pelos próprios cabelos" tem recebido a denominação de meritocracia.

O processo de naturalização de diferenças que, em verdade, são sociais, utilizando o axioma da neutralidade, acaba encobrindo condicionamentos históricos, sociais e econômicos. (Löwy, 1994) Determinantes que não são os únicos fatores, pois aqui não pretendemos desincumbir o sujeito de suas responsabilidades proporcionais, percebemos e valorizamos suas potencialidades de se erguer e de se refazer, no entanto, como Brecht fala até em seu poema dedicado às crianças "Ameixeira", há que ser potência, mas há que existir possibilidade.

A ameixeira

No pátio tem uma ameixeira Pequena, não existe menor Para ninguém nela pisar, Puseram grade ao redor

Deseja se desenvolver Encorpar, ficar bem maior Mas nunca poderá crescer Sem receber a luz do sol.

Difícil saber se é ameixeira, Pois ameixas ainda não há, Mas é ameixeira, com certeza,

Pelo tipo de folhas que dá.

Há que existir possibilidades capazes de aflorar, ou melhor acolher e resguardar a prática de múltiplas e plurais potências igualmente possíveis. Isso porque na verdade há mesmo muitas possibilidades disponíveis, mas estaríamos voluntariamente subordinados àquilo que autores como Jappe e Kurz entendem por sociedade do valor.

Será preciso, porém ir e vir dialeticamente diante deste argumento, caso contrário, estaremos mais uma vez perante os inverossímeis travestidos de possibilidades e perante os pântanos nos quais nos arremessam e não necessariamente nos quais nos atiramos. Isso porque, e a priori e inclusive talvez nem acreditemos na existência destes. 
És o que podias ter sido? Sobre como os jovens contemporâneos são convocados ao inverossímil

Desta sociedade do valor resulta nosso quadro seja de possibilidades, ou seja, daquilo que se pensa e pretende que sejam possibilidades diretamente, mas todas orientadas à finalidade única de gerar valor nesta sociedade e em nada em diálogo com as reais potências de cada "ameixeira" assim reconhecida só pela folha, ou seja, de cada subjetividade.

\section{Um projeto: a sociedade do valor}

Esta sociedade do valor é produto e produtora da própria lógica do capitalismo e ela se organiza ou se sustenta com base em dois elementos fundamentais: o trabalho humano e a expansão. Visa-se uma única coisa: gerar valor para e por gerar valor. Há tempos não se gera mais valor para ou por seu real e mediador valor de uso/utilidade no mundo, capaz de transferir a este nossa representatividade existencial e subjetiva. Na verdade somos, nós mesmos, entidades de valor e nossa "mundanidade" se faz presente naquilo que nos objetiva, é por isso que todo dispêndio de energia humana para a produção desta "mundanidade" resulta em valor, ou seja, transparece o valor da entidade produtora, do sujeito que se empregou naquele seu fazer mundo e fazer no mundo.

Esta configuração imanente dos sujeitos no mundo se afasta, porém deste seu projeto originário e aos poucos vai derivando em outras dimensões e esferas quando as entidades de valor decidem gerá-lo com finalidade nele próprio para acumular unidades deste excedente para poder gerar mais valor com as mesmas finalidades em si.

Aos poucos nosso projeto de "mundanidade" afasta-se de nossas importâncias mais diversas, plurais e subjetivas e passa a representar uma entidade externa a nós mesmos, mas que só existe em referência à nossa humanidade no mundo: o próprio valor em si travestido de entidade autônoma e necessariamente e a partir de então traduzido monetariamente pela forma dinheiro.

Atualmente esta mesma sociedade esbarra, porém em seus próprios fundamentos de base, ou melhor esbarra-se com estes fundamentos de maneira e por vias da oposição. Há uma contradição interna destes e nestes elementos posto que o capitalismo tecnológico só faz liberar trabalho em prol da produtividade e um movimento de expansão infinito num planeta de biodiversidade e recursos finitos, inclusive do ponto de vista do elemento humano, e que é tão irreversível e inexorável quanto diversos outros traços desta, esta contínua, 
ilimitada e crescente expansão é tão igualmente impraticável quanto aquilo a que socialmente a lógica da sociedade do valor vai nos convidando e impondo a, para que possa se sustentar e resistir.

Para podermos desenvolver este raciocínio por partes é preciso destacar que a dinâmica de constituição, funcionamento e institucionalização do capitalismo e sua sociedade do valor não é algo pertencente aos traços do capitalismo contemporâneo atual. O traço histórico do capitalismo e da sociedade do valor sempre foi este, tal qual estruturado e organizado sob as formas do trabalho humano e da expansão. O trabalho como a única intervenção do homem no mundo capaz de gerar o valor desejado e perseguido, e a expansão como uma máxima que impulsiona a busca por novos recursos naturais disponíveis à intervenção do trabalho humano, contínua e ilimitadamente. (Kurz, 1998)

O trabalho humano diz respeito, por sua vez, àquela dimensão da vida ativa, como nos coloca Arendt (2013), por exemplo, condicionada ao próprio e simples fato de estarmos vivos, e se ocupa da nossa apropriada manutenção biológica e orgânica. Dimensão da nossa vida ativa, esta sim, alienante e impositiva. Queremos dizer, a despeito do quanto nos identifiquemos subjetivamente ou estejamos em essência ou vocação, representados e projetados nos rituais de sobrevivência orgânica que nos envolvem o tempo diariamente, precisamos dedicar-nos, todos invariavelmente a esta sobrevivência, caso contrário e literalmente não sobramos ou resistimos vivos para o desfrute das outras dimensões possíveis de uma vida ativa.

Além destas questões em torno do trabalho, e cujo termo aparece traduzido na edição brasileira de 2013 do livro A Condição Humana por labor, para a Arendt (2013), haveria ainda as dimensões da obra (work) e ação. Em ambas dimensões estaria o sujeito em condição de plena liberdade para eleger como e por quais vias mediar-se, representar-se e fazer-se presente, histórico e imortal, no mundo.

A obra é da esfera da vocação, como de um artífice, por exemplo, e cuja finalidade de seu produto é sempre a utilidade ao outro daquilo, a obra traz consigo traços de virtuosidade quando se coloca no lugar do outro, suas possíveis e prováveis necessidades, e busca contribuir para o bem-estar e operacionalização real e concreta deste. As obras trazem consigo as crenças e os "valores" de seus "homo faber" e cujo valor é estabelecido pela utilidade e 
És o que podias ter sido? Sobre como os jovens contemporâneos são convocados ao inverossímil

funcionalidade demonstrada nos atos da troca destas obras, sendo inclusive o espaço destas trocas imanentemente público.

A ação, por sua vez, seria a dimensão da vida ativa, que na esteira das relações estabelecidas nos ambientes e a partir das atmosferas de trocas, estaria necessariamente condicionada pela pluralidade dos sujeitos e cuja tradução prática ou práxis direta seria o discurso, verbal ou não verbal, espontâneo ou institucionalmente enquadrado, informal, semi-formal ou formal e mais ou menos, e especialmente em respeito à nossa atualidade, tecnologicamente mediatizado ou não.

De todas as dimensões da vida ativa dos sujeitos aquela inerentemente política seria, portanto e justamete a ação. O que sustenta e permite que sempre desponte entre as relações, a própria condicionante da ação: a pluralidade, e a experiência da convivialidade. Ou seja, a própria noção ética das relações e existência, também pela preservação desta pluralidade, para então estar novamente assegurada, das dimensões mais políticas e subjetivas das relações humanas: a própria ação. Uma ontologia das mais fenomenológicas do ser no mundo, uma livre e consciente "presença-aî", quase uma experiência de transcendência. (Arendt, 2013)

E por todas estas razões, a ação é a dimensão mais política da vida ativa porque é aquela cuja manifestação está diretamente ligada a um coletivo que pretende se constituir e estar no mundo coletivamente e cujo próprio sentido e a própria práxis depende disso, vocalizando sua própria pluralidade a fim não de organizá-la de um ponto de vista político especificamente institucional, mas a fim de (com)quistar a partir desta pluralidade social a própria expressão e manifestação das diferenças.

Em uma sociedade, porém cujo objetivo exclusivo passa a ser gerar valor, e sendo o trabalho humano (labor e work) o único capaz disto, é preciso que primeiramente tudo vire, ou seja, entendido, vivenciado e experimentado, como trabalho. Isto primeiramente porque se quer vincular permanentemente e de forma naturalizada e naturalizante o homem ao seu trabalho (labor) e segundo porque todas as esferas da vida passam a exigir o estabelecer de um determinado valor para viabilizar as inúmeras possíveis trocas despontantes em nossas relações humanas, então e consequentemente também aprisionadas nesta dimensão, ou seja, a partir também desta hegemonia e homogeneidade quantificadora que se torna o próprio valor. (Kurz, 1998) 
Não por acaso a nossa trilha histórica da secularização vai dos vários deuses naturais, passando ao Deus único cristão, chegando ao homem como cocriador racional e iluminado do mundo - a própria prática da vontade do espírito, como nos colocaria Hegel (1999), o que alcança por fim e então, a ideia do próprio trabalho humano (labor e work). Isto aparece claramente entre autores e debates da época como no livro: "A ética Protestante e o Espírito do Capitalismo" de Weber do início do século XX. Todo o projeto civilizatório da humanidade passa a estar condicionado pelo trabalho (labor), mas esta era apenas uma das dimensões da nossa vida ativa.

\section{Uma resultante: a sociedade do trabalho no capitalismo}

Há uma consequente compressão da vida ativa, e ação e obra (work), passam também à condição de trabalho humano (labor) para que possam resultar em produtos de valor: aquele plausível de ser monetariamente traduzido, como já explicitado, pela forma dinheiro. Sejam eles para atender nossos imperativos orgânicos a partir dos quais estamos condicionados pelo simples fato de estarmos vivos, sejam eles obras que nos imortalizam e representam historicamente no mundo, uma vez que estamos condicionados pela temporalidade, uma temporalidade de caráter irreversível, sejam eles entidades do discurso tradutor e expressão da práxis ação, todos estes "produtos" tem seu valor estabelecido conforme o volume, ou a quantidade de trabalho humano (labor) dedicado a eles num intervalo específico de tempo " $\mathrm{t}$ ". (Arendt, 2013)

Consequentemente num mundo onde tudo é trabalho, tudo passa ou precisa passar também a ser produto e mercadoria. Como isto se agudiza, e como o projeto civilizatório da sociedade humanista, iluminada, regida pelo seu deus da razão é transformado em barbárie e violência é o que majoritariamente nos interessa diante deste capitalismo contemporâneo, capaz por sua vez de produzir peças publicitárias tais quais destacadas. Incitando o sujeito a reconhecer seu valor subjetivo apenas através de uma de suas funções sociais: o trabalho, fazendo-o acreditar que de todas as suas funções sociais possíveis, esta é aquela que unicamente importa, e determinando que o valor que ele produz a partir de seu trabalho só depende do próprio valor que ele tem a oferecer e a imputar neste, como se o seu trabalho ainda de fato o representasse e estivesse livre para servir às suas finalidades mais plurais. 
És o que podias ter sido? Sobre como os jovens contemporâneos são convocados ao inverossímil

O discurso que é a tradução prática da ação, tal como, por exemplo, aparece nestas peças publicitárias, é apropriado pela sociedade do valor das mais perversas e alienantes formas, ou seja, afastando o próprio discurso de sua competência enquanto ação política, ou seja, a natureza inerente daquilo que coletiviza por estar condicionado à pluralidade.

Primeiro por ser a quem resta esta dimensão da vida ativa: a ação, a todos nós nos resta apenas trabalho (labor), segundo porque se apropria da essência mais imanente e originária da significação antropológica e vocacionada de trabalho (work) para o sujeito, para "convidá-lo" a este mesmo trabalho, onde work é transformado em labor. O trabalho com qual o sujeito realmente se encontra em seu cotidiano está completamente esvaziado deste seu projeto de origem.

Vale destacar que uma vez intencionalmente suprimidas as dimensões da obra (work) e da ação das nossas expressões de vida ativa, ou melhor uma vez transformando estas dimensões em uma única entidade subjetiva objetivante e alienadora: a do trabalho (labor), nós terminamos paradoxalmente representados pela dimensão menos apta a fazê-lo, pela dimensão mais alienante, menos livre e consciente, simplesmente condicionada pela vida orgânica num a priori e que não se coloca diante do homem ou permite que ele o faça diante deste imperativo orgânico em sua máxima potência crítica, voluntária e autônoma. Por exemplo, ainda que possa escolher o que comer, o homem não pode escolher não sentir a fome que lhe é biologicamente estabelecida e que está contida em seu organismo vivo, em algum momento sentirá fome e não lhe caberá uma ação ou discurso crítico, por exemplo, para com esta para que simplesmente esta deixe de se manifestar nele.

As nossas outras dimensões de vida ativa que estariam justamente a serviço da desalienação destes imperativos, ou seja, sem estas outras dimensões ou as experienciando a partir da formatação do trabalho para gerar valor, perdemos as tais possibilidades que haveria disponíveis às nossas escolhas críticas, aquelas capazes de assegurar que pudéssemos nos implicar no mundo afetivamente.

Quando todas as esferas da nossa vida são transformadas em produtos ou mercadorias de satisfação efêmera aos moldes do que seriam os produtos do trabalho (labor) pela nossa sobrevivência e existência orgânica, toda a nossa presença no mundo se equipara em nível de satisfação e efemeridade, nossas obras e ações são mercadorias cujo valor é estabelecido pela quantidade de 
trabalho humano ali imputado e cujo propósito é gerar este valor, cuja funcionalidade será melhor operacionalizar nossas vidas para gerarmos mais valor porque vivemos de gerá-lor e acumulá-lo, logo está dado e prontamente resolvido todo o caráter motivacional de nossa existência. (Jappe, 2006)

De volta às questões da barbárie e da violência desta lógica e para melhor explicarmos como resultamos nisso precisamos compreender que tudo se desdobra a partir das reais contradições internas do próprio capitalismo.

O desenvolvimento e crescimento da sociedade do valor, impulsionados ideologicamente pela própria máxima da geração contínua, crescente e ilimitada deste valor, resultam em desenvolvimento produtivo, de produtividade e tecnológico, mas estes dispositivos que atendem às tendências da própria modernização do capitalismo ao aumentarem a produtividade liberam trabalho humano, é a clássica substituição histórica dos homens pelas máquinas.

Mas, se somente o trabalho humano é capaz de gerar valor, e por isso o homem é levado às fábricas para se dedicar incansavelmente à geração de valor em troca de uma remuneração compensatória e que lhe permitiria por sua vez adquirir o bem cuja valoração dependeu exatamente do trabalho também de outros, se este trabalho humano é liberado e a máquina passa a produzir o bem ou a mercadoria, inevitavelmente o seu valor decresce e disso resulta que será preciso um conjunto maior de bens para que se possa acumular um mesmo montante de valor. (Kurz, 1998)

Esta é sua primeira e mais primária contradição: depender do trabalho humano para gerar o valor que deseja acumular e liberar trabalho humano à medida que o valor que gera se moderniza e desenvolve.

Somado a isto temos os limites geográficos e naturais que hoje esta sociedade do valor enfrenta a respeito de suas possibilidades de expansão. Não há mais para onde se expandir ilimitadamente, como quando se imaginava ser à época da colonização, por exemplo, e cujo movimento de contínua expansão assegurava ao capitalismo a reabsorção de todo o trabalho humano liberado nas novas regiões que eram, pois palcos eminentes do desenvolvimento da produtividade até que fosse chegado o momento do novo movimento ou salto de expansão.

Os pares possíveis das regiões desenvolvidas àquelas a se desenvolverem, na teoria se esgotaram e na prática para que se concretizassem, hoje, exigiriam efetiva redistribuição de riqueza e volume de valor acumulado de maneira concentrada. 
És o que podias ter sido? Sobre como os jovens contemporâneos são convocados ao inverossímil

A saída para nós é perceber que não há uma saída senão um exercício de crítica radical desta sociedade e sua lógica.

A saída é dizermos não aos múltiplos pântanos nos quais querem nos arremessar recusando a lógica que nos responsabiliza por eles e que nos obriga à forma hegemônica da individualidade, mas como operacionalizar isto, eis a questão? Dependemos dos nossos trabalhos pela sustentabilidade literal dos nossos imperativos orgânicos e dentre as múltiplas possibilidades da nossa "vida ativa" só nos resta trabalho (labor) para acessarmos todas as nossas esferas de vida privada e pública e que foram igualmente transformadas em mercadorias e produtos.

A propósito esta foi a saída da sociedade do valor: mercantilizar todas as esferas e dimensões de nossa vida, transformar tudo em possível produto resultante de trabalho, inclusive o conhecimento científico, ditando os melhores meios, formatos e estruturações para uma melhor e maior produtividade, de conhecimento.

O dinheiro também foi mercantilizado em forma de capital financeiro e os sujeitos em forma de capital humano. Tudo isto por si só já seriam traços suficientes de barbárie intencionalmente constituída e planejada posto que aliena os sujeitos e faz-lhes escapar a própria vida, mas além disso há todos os desdobramentos da mão de obra desempregada pela constante liberação de trabalho humano, sua marginalização pela impossibilidade de gerar e trocar valor e consequentemente seu despertencimento à lógica e pelo qual somos individualmente e de muitas maneiras violentas cobrados e responsabilizados.

Continua então válido o questionamento feito pelo psicólogo Botomé (2010) ainda no Brasil da década de 70, e repetido integralmente em publicação recente: "A quem devemos "tratar e mudar": O homem que sofre ou as condições que ofazem sofrer ou produziram seu sofrimento?"

\section{Referências}

Arendt, H. (2013). A condição humana. Rio de Janeiro: Forense Universitária.

Botomé, S.P. (2010). A quem nós, psicólogos, servimos de fato?. In O.H. Yamamoto \& A.L.F. Costa (orgs.) Escritos sobre a profissão de psicólogo no Brasil. Natal: EDUFRN. 
Costa, A.L.F. (org.) (2010). Escritos sobre a profissão de psicólogo no Brasil. Natal: EDUFRN.

Hegel, G.W.F. (1999). Filosofia da História. Brasília: Editora Universidade de Brasília.

Jappe, A. (2006). As aventuras da mercadoria: para uma nova crítica do valor. Lisboa: Antígona.

Kurz, R. (1998). Os últimos combates. Petrópolis: Vozes.

Löwy, M. (1994). As aventuras de Karl Marx contra o Barão de Münchhausen: Marxismo e Positivismo na Sociologia do Conhecimento. São Paulo: Editora Cortez.

Raspe, R.E. (1895). As Surpreendentes Aventuras do Barão de Munchause.

\section{Imagens}

www.cunhavaz.com

http://culturvisflul.blogspot.com.br 


\title{
A pesquisa em Ciências da Comunicação com o uso das novas mídias digitais
}

\author{
Paulo Eduardo Silva Lins Cajazeira \\ Universidade Federal do Cariri \\ E-mail: paulo.cajazeira@ufca.edu.br
}

\begin{abstract}
Resumo
Este estudo procura compreender as alterações no processo da produção e divulgação científica com o uso das novas mídias digitais. Para tanto, verificouse que os métodos qualitativos de pesquisa, na produção científica, são afetados pelo advento da Internet desde o pensar no grupo de entrevistados à elaboração dos questionários on-line e a sua efetiva aplicação. O nosso objetivo é discutir o papel das tecnologias digitais no processo de coleta, análise de dados, divulgação e a participação na pesquisa científica. Como objeto de análise, nos focamos na observação de duas pesquisas na área de Ciências da Comunicação.

A primeira realizada no âmbito do Laboratório de Comunicação e Conteúdos On-line da Universidade da Beira Interior (Portugal) e a segunda coordenada em conjunto por investigadores brasileiros da Universidade Federal do Paraná (Brasil) e da Universidade de Brasília (Brasil) realizada com participantes de diferentes países, com identidades culturais similares, de cunho qualitativo, com objetivos e contextos que ilustram o modo como a instrumentalização dos questionários online na coleta de dados pode ser realizado utilizando-se de Redes Sociais On-line e de recursos da Internet para adesão de novos públicos.
\end{abstract}

Palavras-chave: tecnologia digital; ciência; métodos qualitativos; pesquisa científica.

\begin{abstract}
This study aims to understand the changes in the process of production and science propagation using of new digital media. Therefore, it was verified that qualitative methods of research, in the scientific production, are affected by the

advent of the Internet from the thinking of the interviewee group to the online questionnaires elaboration and their effective implementation. Our goal is to discuss the role of the digital technologies in the collection process, data analy-
\end{abstract}


sis, propagation and participation in scientific research. As the object of analysis, we focus on the observation of two studies in Communication Sciences area. The first one accomplished in the Laboratory of Communication and Online Content from the University of Beira Interior (Portugal) and the second coordinated jointly by brazilian researchers at the Federal University of Paraná (Brazil) and the National University of Brasilia (Brazil) fulfilled with participants from different countries with similar cultural identities, with qualitative nature, with goals and contexts that illustrate how the instrumentalization of online questionnaires in data collection can be executed using online Social Networks and Internet resources for new audiences accession.

Keywords: digital technology; science; qualitative methods; scientific research.

\section{Introdução}

$\mathrm{O}$ objetivo deste estudo é discutir o papel das tecnologias digitais no processo de coleta, análise de dados e divulgação e participação de pesquisas qualitativas com o uso de inquéritos on-line e redes digitais na Internet. Acreditamos que, a tecnologia utilizada altera o processo da produção científica. Se antes escolhíamos um grupo de entrevistados na execução de pesquisas qualitativas e fazíamos as entrevistas face a face, hoje, com as possibilidades infinitas da Internet, ampliam-se de maneira significativa as redes de contatos e novas adesões são incluídas no processo de construção do conhecimento. Assim, estreitam-se as fronteiras comunicacionais entre pesquisadores e pesquisados, produtores de conhecimento e leitores. Com isso, temos um universo mais representativo e válido de resultados que nos permitem evidenciar outros aspectos da investigação em realidades distintas.

Outra alteração processual verificada é a utilização de redes sociais digitais na divulgação e compartilhamento de trabalhos científicos oriundos de revistas, repositórios de universidades e bibliotecas virtuais. Ademais, o discurso em redes sociais digitais na divulgação do conteúdo científico adquire características muito particulares, ora se aproximando da oralidade, ora da escrita, e o fazer ciência é transformado pela tecnologia ao aproximar-se de um número infinito de novos leitores. As novas mídias digitais assumem um papel fundamental no fazer ciência e divulgar o conhecimento científico. 
Criamos o seguinte problema de pesquisa neste estudo: "Em que medida as novas mídias digitais na Internet podem moldar a análise do investigador, bem como ampliar a divulgação dos resultados na área das Ciências da Comunicação?". A nossa hipótese é apoiada em uma perspectiva teórica, na qual o conhecimento é produzido por um coletivo de seres conectados digitalmente em comunidades virtuais aos diversos processos midiáticos na internet, que se utilizam dessa metodologia para ampliação do seu universo de leitores.

\section{Fundamentos teóricos da investigação}

Essas mudanças - de distribuição para circulação do conhecimento - sinalizam na direção de um modelo mais aberto de investigação, em que os leitores (ou novos leitores conectados) estão moldando, compartilhando, reconfigurando e remixando conteúdos de mídia. Estes indivíduos, consumidores de conhecimento científico, não estão isolados, mas ligados a grupos virtuais, por meio de redes sociais digitais ou listas on-line na Internet. São verdadeiras "comunidades virtuais" mais amplas que propagam conteúdos e participam de discussões acadêmicas muito além de sua vizinhança geográfica (Jenkins, Ford \& Green, 2014). Segundo Henry Jenkins, o pesquisador Howard Rheingold foi um dos primeiros autores a efetivamente utilizar o termo "comunidade virtual":

"As comunidades virtuais são agregados sociais que surgem da Rede Internet, quando uma quantidade suficiente de gente leva adiante essas discussões públicas durante um tempo suficiente, com suficientes sentimentos humanos, para formar redes de relações pessoais no ciberespaço" (1995, p.20).

Segundo Raquel Recuero (2011), os elementos formadores da comunidade virtual seriam: as discussões públicas; as pessoas que se encontram e reencontram, ou que ainda mantêm contato através da Internet (para levar adiante a discussão); o tempo; e o sentimento. Esses elementos, combinados através do ciberespaço, poderiam ser formadores de redes de relações sociais, constituindo-se em comunidades. As comunidades virtuais são comunidades simbólicas, ou seja, cujos membros "estão conectados primariamente pelas trocas simbólicas (no caso, eletrônicas), mais do que pela interação face a face" (Raquel Recuero, 2011, p. 135). A autora salienta ainda que a interação é considerada um dos elementos da comunidade virtual, além da fronteira 
simbólica para os grupos participantes. É no ciberespaço que as relações são construídas, através da interação mediada pelo computador. Muitos acreditam que a mediação por computador, inclusive, facilita para que os atores demonstrem intimidade e proximidade nas relações sociais on-line e off-line.

Conforme Recuero (2011) nos explica, os interesses homogêneos das pessoas participantes das comunidades virtuais podem aumentar consideravelmente a sensação de empatia, compreensão e suporte mútuo nesses grupos. Ou seja, quanto mais parecidos e mais interesses em comum tiverem os atores sociais, maior a possibilidade de formar grupos coesos com características de comunidade. Lemos (2002) salienta que as comunidades virtuais eletrônicas são agregações em torno de interesse comuns, independentes de fronteiras ou demarcações territoriais fixas. O autor ressalta que o interesse comum e o fim da localidade espacial são uma das características dos sujeitos das comunidades virtuais. Além disso, agrega duas dimensões ao seu entendimento do conceito de comunidade virtual: o território simbólico e a dimensão temporal, onde a comunidade deve durar como comunidade. Ele ainda ressalta que qualquer ambiente onde há comunicação mediada por computador pode ou não ser uma comunidade, dependendo do tipo de relações que está presente (Recuero, 2011).

O poder comunicativo e a ampla tecnologia disponível podem ser adaptados aos métodos qualitativos de coleta e análise de dados. Um inquérito on-line, a exemplo, ao ser compartilhado em listas de e-mails ou em redes sociais transforma os seus participantes em uma comunidade virtual que se faz e desfaz com o final da investigação. Contudo, apenas o investigador consegue visualizá-los dessa maneira, visto que não há interação dentro do grupo, apenas a mediação do processo comunicativo. Esses grupos virtuais devem ser estudados, a partir da perspectiva de sociabilidade na Internet e de re-territorialização em ambientes virtuais.

\section{O processo de territorialização, des-territorialização e re-territorializa- ção na Internet}

As comunidades virtuais forjadas pelos participantes no ciberespaço e possuidoras de fronteiras simbólicas são delineadas por tópicos de interesse. Segundo Castells (2003), o termo "comunidades virtuais" foi associado ao surgimento de novos padrões de interação social ocasionados, principalmente, 
pela Internet. Compreendemos que isso interfere na construção de um novo conceito de comunidade, com menos ênfase no seu componente cultural e mais ênfase no seu papel social.

A investigação on-line é uma possibilidade metodológica para o pesquisador e consiste em um conjunto de práticas materiais e interpretativas que dão visibilidade ao objeto analisado. Essas práticas transformam a pesquisa em uma série de representações. Um mundo desterritorializado, onde não existem barreiras de tempo e de espaço para que as pessoas se comuniquem. Uma nova era que oferece múltiplas possibilidades de investigar em que o espaço físico neste novo paradigma, deixa de ser o local exclusivo para a construção do conhecimento.

Criar um território científico é se apropriar, material e simbolicamente, das diversas dimensões que o conhecimento possa alcançar. O Estado e as instituições tendem sempre a manter territórios como forma de poder e controle. Toda territorialização é uma significação do território (político, econômico, simbólico, subjetivo) e toda des-territorialização, ressignificação, formas de combate à inscrição da vida em um "terroir", linhas de fuga (Lemos, 2005). Ao expandirmos as possibilidades de investigação entre comunidades situadas em cidades, países e continentes diferentes, mas com identidades culturais similares, estamos a criar novos territórios na investigação. Um processo duplo de des-territorialização e re-territorialização, nos quais os ambientes virtuais: listas de e-mails, sites de redes sociais digitais ou links de inquéritos on-line são os novos territórios das investigações (re-territorializados).

Vivemos a era das redes telemáticas, a cibercultura é uma cultura de desterritorialização, mas nos coloca em meio a novas fronteiras controladas e de acesso restrito aos pesquisadores e seus pesquisados. A des-territorialização informacional afeta a política, a economia, o sujeito, os vínculos identitários, o corpo, a arte. A internet é, efetivamente, máquina des-territorializante sob os aspectos político (acesso e ação além de fronteiras), econômico (circulação financeira mundial), cultural (consumo de bens simbólicos mundiais) e subjetivo (influência global na formação do sujeito). Estão em marcha processos de desencaixe e de compressão espaço-tempo na cibercultura (Lemos, 2005).

Um site na internet é sempre uma territorialização ou uma des-re-territorialização, lugar de controle que pode ser uma linha de fuga ao poder instituído, ou a reafirmação desse mesmo poder. Podemos dizer aqui que a cibercultura não apenas destrói hierarquias e fronteiras, mas também as institui 
em um processo complexo de des-re-territorializações. Ou seja, as fronteiras reduzem, estreitam o tempo e o espaço entre as comunidades virtuais, e, dessa forma, criam-se novos territórios para a pesquisa científica. No caso do investigador se utilizar de métodos qualitativos: pesquisas focais, questionários, estudos de caso, inquéritos on-line, entrevistas via-internet ou outras ferramentas de pesquisa, estes lhe servem para legitimar os novos territórios concebidos com o advento da cibercultura.

Os processos de territorialização e des-territorializações nos auxiliam na compreensão melhor a dinâmica social imposta pelas novas tecnologias digitais de comunicação e informação. A partir disso, podemos definir a noção de território de forma abrangente e, como as tecnologias digitais estão criando processos de re-territorialização, em meio a uma dinâmica mais ampla de des-territorialização do ciberespaço. Esses processos mostram como o espaço eletrônico está em interface com o espaço urbano, trazendo possibilidade de novas significações para o espaço acadêmico da investigação (Lemos, 2005).

De acordo com o pesquisador Pierre Lévy (1996), essas características estão intrinsicamente ligadas ao processo de "des-territorialização do presente", visto que não há barreiras de acesso a bens de consumo, produtos e comunicação. O importante nesta sociedade não é a tecnologia em si, mas as possibilidades de interação que elas proporcionam através de uma cultura digital. Segundo Castells as novas tecnologias amplificam as possibilidades de apropriação dos usuários da informação e redefinir as interações sociais:

"O que caracteriza a revolução tecnológica atual não é o caráter central do conhecimento e da informação, mas a aplicação deste conhecimento e informação a aparatos de geração de conhecimento e processamento da informação/comunicação, em um círculo de retroalimentação acumulativa entre a inovação e seus usos". A difusão da tecnologia amplifica infinitamente seu poder ao se apropriar de seus usuários e redefinilos. As novas tecnologias da informação não são apenas ferramentas para se aplicar, mas processos para se desenvolver. (...) Pela primeira vez na história, a mente humana é uma força produtiva direta, não apenas um elemento decisivo do sistema de produção" (2007, p.7).

Dessa forma, concordamos com o autor quando se refere que estamos vivendo uma revolução tecnológica, efeito da globalização das novas identidades da modernidade. O desafio é saber de que maneira todo este arsenal de 
informações que não encontra barreiras de tempo e de espaço poderá contribuir para a democratização do conhecimento científico e as suas experiências empíricas.

Entendemos as novas identidades na contemporaneidade como resultados do fenômeno da globalização, que segundo Anthony McGrew (1992), se refere àqueles processos, atuantes numa escala global, que atravessam fronteiras nacionais, integrando e conectando comunidades e organizações em novas combinações de espaço-tempo, tornando o mundo, em realidade e em experiência, mais interconectado. A globalização implica um movimento de distanciamento da ideia sociológica clássica da "sociedade" como um sistema bem delimitado e sua substituição por uma perspectiva que se concentra na forma como a vida social está ordenada ao longo do tempo e do espaço (Giddens, 1990, p. 64). Essas novas características temporais e espaciais, que resultam na compreensão de distâncias e de escalas importantes da globalização a ter efeito sobre as identidades culturais.

A globalização não é um fenômeno recente. Segundo Stuart Hall (2003), os estados-nação nunca foram tão autônomos ou soberanos quanto pretendiam. O capital nunca permitiu que suas aspirações fossem determinadas por fronteiras nacionais. Assim, tanto a tendência à autonomia nacional quanto a tendência à globalização estão profundamente enraizadas na modernidade (Hall, 2003).

A partir dessas reflexões, lançamos mão de uma pergunta norteadora em nosso estudo para melhor compreensão da pesquisa: "Que impacto desempenha a globalização sobre a construção das identidades culturais nos estudos empíricos?". Conforme cita Stuart Hall (2003), uma das características principais da globalização seria o entendimento da dinâmica do "espaço-tempo", a aceleração dos processos globais, de forma que se sente que o mundo é menor e as distâncias mais curtas, que os eventos em um determinado lugar têm um impacto imediato sobre as pessoas e lugares situados a uma grande distância. $\mathrm{O}$ autor David Harvey argumenta que:

"À medida que o espaço se encolhe para se tornar uma aldeia "global" de telecomunicações e uma "espaçonave planetária" de interdependências econômicas e ecológicas - e à medida em que os horizontes temporais se encurtam até ao ponto em que o presente é tudo que existem temos que aprender a lidar com um sentimento avassalador de compreensão de nossos mundos espaciais e temporais (1989, p. 240)". 
O que é importante para o nosso argumento quanto ao impacto da globalização sobre a construção das identidades nos estudos empíricos é que o tempo e o espaço são também as coordenadas básicas de todos os sistemas de representação da pesquisa.

Os lugares permanecem fixos; é neles que temos "raízes". Entretanto, o espaço pode ser "cruzado" num piscar de olhos. Colocado ao nível do processo de investigação entre indivíduos com identidades culturais similares, mas distantes fisicamente, as identificações "globais" começam a deslocar e, algumas vezes, a apagar, as identidades locais ou nacionais. Na pesquisa, a tendência é em direção a um olhar de hábitos e interesses dos entrevistados influenciados pelo mercado global de estilos, lugares e imagens de mídia e pelos sistemas de comunicação global interligados. As identidades ficam definidas como parte de um fenômeno conhecido como "homogeneização cultural". O que estamos discutindo é a tensão entre as identidades "locais" e "globais", que alteram o processo de construção dos métodos qualitativos de pesquisa. Os interesses de jovens estudantes de Ciências da Comunicação no Brasil são praticamente os mesmos dos jovens europeus. A globalização criou novos modos de articulação e os costumes particulares tornaram-se modos universais.

\section{Metodologia}

Como objeto de análise foram escolhidas duas investigações empíricas de caráter qualitativo que se utilizam de mídias digitais. São estudos acadêmicos direcionados a estudantes de Ciências da Comunicação e Jornalismo do Brasil, Portugal e de outros países. A primeira, em nível de pesquisa pós-doutoral, desenvolvemos no Laboratório de Comunicação e Conteúdos On-line da Universidade da Beira Interior, em Portugal, no ano de 2014, sob a supervisão do professor António Fidalgo (UBI) e com o financiamento da Fundação CAPES do Brasil. A segunda, aplicada em quase 30 países, tem na coordenação brasileira dois professores de cursos de Comunicação Social de universidade públicas brasileiras, Cláudia Quadros da Universidade Federal do Paraná (UFPR) e Fábio Pereira da Universidade de Brasília (UnB).

Ambos os estudos envolvem a participação on-line de entrevistados, a convocação em listas de e-mails de centros de investigação e em sites de redes sociais digitais na Internet. São inquéritos desenvolvidos para um grupo 
específico de pessoas: estudantes de Ciências da Comunicação e Jornalismo nos três níveis de formação: graduação, mestrado e doutoramento. E, tanto na investigação luso-brasileira quanto na brasileira, não fazem-se distinções às fronteiras territoriais. Os inquiridos podem pertencer a realidades distintas e espaços físicos diferentes. Ou seja, fazem parte de comunidades acadêmicas distintas, cidades, países e continentes diferentes. Uma entrevista padrão realizada no Brasil ou na Europa responde a hábitos e costumes similares, que dominam as redes globais. Optar por realizar uma pesquisa em escala mundial, em nossa opinião, não interfere nos resultados finais, pois as evidências nos mostram que a globalização está por toda a parte.

\section{Descrição da primeira investigação: o estudo luso-brasileiro}

$\mathrm{Na}$ investigação luso-brasileira, desenvolvemos uma pesquisa qualitativa com cerca de 17 perguntas, sendo 16 fechadas e apenas uma aberta. A intenção era de verificar os hábitos de consumo de televisão, internet e a rede social Facebook por estudantes brasileiros e portugueses nos três ciclos: graduação, mestrado e doutorado, entre 18 e 35 anos. Com o título "Participação das audiências de TV no Facebook", o inquérito esteve aberto de 03 de abril a 03 de maio de 2014. A convocação dos participantes realizou-se por meio de listas de e-mails: Sociedade Brasileira de Pesquisadores em Jornalismo, Grupo de Pesquisa de Jornalismo On-line da Universidade Federal da Bahia e nos Programas de Pós-Graduação em Comunicação da Universidade Federal do Paraná, Universidade Estadual de Ponta Grossa, Universidade Federal da Bahia, Universidade Federal do Pará, Universidade da Beira Interior (Portugal), Universidade Federal de Pernambuco e Universidade Federal de Santa Catarina. E na página no Facebook do Curso de Comunicação Social Jornalismo e do Programa de Pós-Graduação em Desenvolvimento Regional Sustentável da Universidade Federal do Cariri, Ceará, Brasil. O inquérito teve a adesão de 111 participantes enquanto esteve no ar.

Este estudo representou uma pequena amostra da relação luso-brasileira com a informação sob a perspectiva do uso de suportes variados no consumo de notícia. Esta análise permitiu identificar a visão quanto aos benefícios do uso da tevê e da internet na dieta midiática de informação dos seus participantes. O instrumento de coleta foi criado no Labcom Online da Universidade da Beira Interior, em Portugal. Ao questionário elaboraram-se perguntas fecha- 
das, condicionantes ao nível de resposta do inquirido e ao final uma pergunta aberta (Cajazeira, 2015).

Consideramos consistências lógicas entre as perguntas, que garantiram a qualidade na análise da coleta de dados. Estudaram-se, anteriormente, alguns modelos de questionários desenvolvidos pelo Laboratório de Comunicação e Conteúdos On-line da Universidade da Beira interior, Observatório de Comunicação de Portugal e a Secretaria de Comunicação Social da Presidência da república Federativa do Brasil (Secom). A plataforma do inquérito online (www.inqueritos.ubi.pt), na sua apresentação, incorporou o seguinte texto explicativo dos propósitos da investigação:

\begin{abstract}
"Esta investigação desenvolve uma pesquisa na área de comunicação online e televisão sobre as participações da audiência do jornalismo televisivo no Facebook. A investigação está sediada no LabCom da Universidade da Beira Interior (UBI), Portugal. Solicitamos o preenchimento deste inquérito, até 03 de maio de 2014. Com os resultados obtidos, esperamos contribuir para compreensão da participação da audiência de TV no Facebook. Por isso, agradecemos a sua participação e cuidado no preenchimento do questionário. Todas as respostas são de caráter anônimo e usadas apenas para fins acadêmicos" (Cajazeira, 2015, p.51).
\end{abstract}

$\mathrm{Na}$ análise dos dados, dividimos três formas de consumo: TV, Facebook e suporte de uso. O questionário buscou explorar o consumo de TV. Desenvolveram-se algumas perguntas à compreensão da figura do fã do telejornal. As perguntas foram baseadas no problema da pesquisa, nas hipóteses e nas reflexões realizadas durante a investigação. Os questionamentos versaram sobre os procedimentos quanto às possibilidades oferecidas pela televisão na Era digital. Na última parte do inquérito verificou-se o uso do suporte para ver TV e acessar a internet ou a existência de situações ambivalentes de consumo. Como última pergunta do inquérito, realizou-se na forma aberta, a fim de observar como se posicionava os inquiridos quanto ao hábito de ver TV em duas telas ou ecrãs.

\title{
A descrição da primeira investigação: o estudo brasileiro
}

O projeto de pesquisa internacional, "O estudante do jornalismo no Mundo", no Brasil, tem a coordenação geral de Fábio Pereira (UNB) e Claudia 
Quadros (UFPR). Neste estudo, os estudantes de jornalismo de quase 30 países respondem ao questionário, que tem como objetivo conhecer o perfil dos inquiridos. A pesquisa preserva a identidade dos participantes. Como afirma parte do texto no cabeçalho do inquérito: "Se você é estudante de jornalismo, agradecemos a sua participação. Gostaríamos que respondessem todas as perguntas. O tempo médio de preenchimento é de 10 minutos. A pesquisa preserva a identidade dos participantes". A distribuição do inquérito on-line foi realizada em listas de e-mails de entidades associativas na área de Ciências da Comunicação no Brasil (Compós e SBPJor), Grupo de Pesquisa em Jornalismo On-line (UFBA/Brasil) entre outras, além de partilhamento em sites de redes sociais digitais.

O instrumento de coleta criado na plataforma Google Forms permite a coleta e organização das respostas automatizadas, poupando tempo do investigador e dando-lhe melhores condições para a análise do estudo. Este aplicativo encontra-se no Google Docs, um serviço da Google que permite a edição colaborativa de documentos. Uma das vantagens que verificamos nesse procedimento é a facilidade de uso e a forma organizada e simples com que são apresentadas as respostas. Em nossa análise, no questionário de 31 perguntas, evidenciam-se cinco grandes áreas: escolha profissional, mídia: funções e desejo de atuação profissional, formação profissional do jornalista, dados pessoais e carreira no jornalismo. O questionário esteve aberto nos meses de fevereiro e março de 2015.

O que podemos perceber na análise é que o investigador não precisa mais estar circunscrito a canais convencionais de divulgação de seu trabalho. O processo dá-se desde a sua concepção a leitura dos resultados finais na interação com o computador: a seleção da amostra, o instrumento de coleta, a leitura dos dados, o acompanhamento das respostas, o processamento dos gráficos, a escrita e a divulgação em periódicos on-line com o uso da tecnologia digital.

A informatização mostra-se presente em todas as etapas do processo. Qualquer dado, pode ser divulgado, desde que haja o acesso a uma página na Internet, a qualquer momento, em qualquer lugar. Os horários e locais das entrevistas científicas também são agora de interesse do entrevistado da pesquisa e não mais restrito a acordos com o entrevistador em data e horários pré-estabelecidos. O investigador tem a possibilidade on-line de acompanhar $\mathrm{o}$ andamento da pesquisa à medida que os inquéritos vão sendo respondidos, 
fazendo alterações e observações necessárias no estudo. Por outro lado, verificamos a necessidade de orientações no preenchimento dos questionários aos inquiridos. Como não há possibilidade de haver interação face a face, nos grupos on-line, exige-se a necessidade de um tutorial pedagógico de orientação, caso contrário, algumas perguntas, por falta de entendimento do respondente, podem ficar sem respostas.

\section{Considerações Finais}

A Internet é o apoio principal à investigação científica, ao acesso a artigos das mais variadas áreas, com rapidez e custo baixo. Esse estudo evidenciou que a democratização do acesso aos textos completos de publicações científicas de acesso livre, a instrumentalização, divulgação e distribuição de conteúdo científico em listas de e-mails, sites e redes digitais on-line é uma tendência que permite aumentar a interatividade entre autores e leitores. Proporcionando, dessa forma, uma ampla circulação de conteúdo científico.

Entretanto, faz-se necessário resolver alguns problemas técnicos, como a dificuldade de acesso à Internet em países com número insuficiente de computadores e a falta de investimentos em tecnologia e informatização das cidades. Com o avanço da tecnologia de informação, comunicação e a busca desenfreada de informações, a publicação científica obrigou-se a tomar um novo rumo: estar disponível a todos em qualquer hora e lugar. Sendo assim, favorecem-se investigadores e leitores desse novo ecossistema midiático reconfigurado por mudanças de hábitos de apropriação da informação. Mediante o exposto neste artigo, pode-se afirmar que os processos eletrônicos de produção de estudos científicos possuem grandes vantagens, visto que encontramos um aumento nas comunicações entre investigadores, investigados e novos leitores. O crescimento da pesquisa, com uso de mídias digitais, beneficia não apenas ao investigador, mas a toda comunidade científica, contribuindo com a qualidade do fazer e difundir Ciência.

\section{Referências}

Cajazeira, P.E. (2015). A audiência convergida do telejornal nas Redes Sociais. Covilhã, Portugal : Editora Livros Labcom. 
Castells. M. (2003). A Galáxia Internet: reflexões sobre a Internet, negócios e a sociedade. Rio de Janeiro: Editora Jorge Zahar.

Castells. M. (2007). Sociedade em Rede: A Era da Informação: economia, sociedade e cultura. Rio de Janeiro: Editora Paz e Terra.

Giddens, A. (1990). The Consequence of Modernity. In A identidade cultural na pós-modernidade. Rio de Janeiro: Editora D P \& A.

Hall, S. (2003). A identidade cultural na pós-modernidade. Rio de Janeiro, Brasil: Editora D P\&A.

Harvey, D. (1989). The Condition of Post-Modernity. In A identidade cultural na pós-modernidade. Rio de Janeiro: Editora D P \& A.

Jenkins, H; Green, J. \& Ford, S. (2014). Cultura da Conexão: criando valor e significável por meio da mídia propagável. Rio de Janeiro: Editora Aleph.

Lemos, A. (2002). Cibercultura e Mobilidade. A Era da Conexão. Disponível em: www.intercom.org.br. Acesso: 10.02.2015.

Lemos, A. (2005). Ciber-Cultura- Remix. Disponível em: www.hrenatoh.net. Acesso: 10.02.2015.

Lévy. P. (1996). O que é virtual. São Paulo: Editora 34.

McGrew, A. (1992). A global society. In A identidade cultural na pósmodernidade. Rio de Janeiro: Editora D P \& A.

Recuero, R. (2011). Redes Sociais na Internet. Porto Alegre: Editora Sulina.

Reinhgold, H. (2000). The Virtual Community: Homesteading on the Electronic Frontier. Sociedade em Rede: A Era da Informação: economia, sociedade e cultura. Rio de Janeiro: Editora Paz e Terra. 
$\bigoplus$

$\bigoplus$

$\oplus$ 


\title{
A hegemonia científica e o senso comum na internet: uma análise segundo a Epistemologia do Sul de Boaventura de Sousa Santos
}

\author{
Cleber Femina \& Kênia Maia \\ Universidade Federal do Rio Grande do Norte \\ E-mail: keniamaialyahoo.com
}

\begin{abstract}
Resumo
As concepções de Boaventura de Sousa Santos $(1995 ; 2010)$ sobre o atual cenário epistemológico nos orientam para compreender o relacionamento entre o conhecimento científico e o senso comum. Partindo do seu pensamento, principalmente no que tange à necessidade de uma ruptura com o modelo vigente, hegemônico e totalizante, para que a ciência expanda suas fronteiras e reconheça como válidas outras formas de saber, analisa-

mos os discursos envolvidos em um debate acerca dessa relação em um blog na internet. De acordo com as ideias de Michel Foucault (1999) e Eni Orlandi (2012) vimos que o pensamento científico moderno ainda exerce hegemonia sobre os demais saberes, porém o espaço virtual da internet permite um combate e pode ser utilizado como meio para o exercício da epistemologia proposta por Santos.
\end{abstract}

Palavras-chaves: Epistemologias do Sul; Ciência; Senso Comum; Internet.

\begin{abstract}
The conceptions of Boaventura de Sousa Santos $(1995 ;$ 2010) on the current epistemological setting guide us to understand the relationship between scientific knowledge and common sense. Starting from his thinking, especially with regard to the need of a rupture with the current model, hegemonic and to-

talizing, for science to expand its borders and recognize as valid other ways of knowing, we analyzed the speeches involved in a debate about that relationship in a blog on the internet. According to Michel Foucault (1999) and Eni Orlandi's (2012) ideas we saw that modern scientific thought still exerts hege-
\end{abstract}

Estudos em Comunicação no 21, 75-91 
mony over other forms of knowledge, but the virtual space of the internet allows to fight back, and can be used as a mean for the exercise of epistemology advocated by Santos.

Keywords: Southern Epistemologies; Science; Common sense; Internet.

\section{Introdução}

A relação entre o conhecimento científico ${ }^{1}$ e o senso comum é conflituosa desde que o primeiro se tornou sinônimo de verdade absoluta enquanto o segundo, estabelecido no patamar de sabedoria popular, foi desvalorizado e associado a falta de conhecimento acadêmico. Esse embate também pode ser percebido por um viés político e econômico ao observamos o movimento colonizador. Com o progresso tecnológico de algumas nações, o saber científico passou a se instituir como aquele ligado à evolução enquanto o senso comum foi atribuído ao saber dos países em "atraso" (Santos, 2010).

O pensamento do sociólogo português Boaventura de Sousa Santos (1995; 2006; 2010) sobre a ciência é construído a partir deste prisma histórico-social. $\mathrm{O}$ pesquisador enxerga na dominação colonialista uma igual sobreposição epistemológica que relega os saberes locais a posições subalternas e, muitas vezes, acaba por suprimi-los.

No combate a essa dominação epistemológica, Santos (1995) questiona os paradigmas que sustentam a ciência moderna enquanto instituição legitimadora da verdade, aponta os prejuízos que sua manutenção traz às sociedades que vivem sob a hegemonia capitalista vigente e sugere uma nova epistemologia que se aproxime do saber popular e que promova uma ciência que gere resultados positivos para todas as nações.

Entretanto, esse discurso se encontra enraizado de tal maneira no mundo atual que, como o próprio pesquisador reconhece (Santos, 2010), ele toma forma dentro das sociedades nas quais ele foi imposto, passando, às vezes, despercebido por aqueles que o pronunciam.

Neste trabalho, objetivamos encontrar traços dessa relação conflituosa entre o conhecimento científico e o senso comum, utilizando como parâmetros

1. Entende-se por conhecimento científico o saber produzido dentro de instituições de pesquisa e que estejam de acordo com preceitos teóricos e metodológicos do campo científico. 
A hegemonia científica e o senso comum na internet: uma análise segundo a Epistemologia do Sul de Boaventura de Sousa Santos

teóricos algumas das obras de Boaventura de Sousa Santos. Para isso, iremos analisar os discursos contidos em um debate entre um paisagista, assumidamente um prático empirista, e um acadêmico graduado em Biologia e com mestrado e doutorado em Liquenologia. Ambos debateram acerca da relação entre liquens e árvores em um site de conteúdo sobre jardinagem e paisagismo. Também verificaremos como o debate entre ambos afetam os demais frequentadores da referida página.

\section{Desenvolvimento}

Rubem Alves (1981) disse no início da década de 1980 que a ciência era como uma hipertrofia do senso comum, uma especialização de um saber. $\mathrm{O}$ autor ressaltava, ainda, que a imagem do cientista está ligada diretamente a uma posição de autoridade que este havia conseguido dentro da sociedade. Essa especialização e, principalmente, essa autoridade são reflexos do desenvolvimento do pensamento científico moderno, o qual tem suas bases no Iluminismo e que vê no conhecimento científico o verdadeiro saber em detrimento do senso comum. E isto se mantém nestes mesmos moldes até os dias atuais, como o próprio Alves (1981) exemplifica, quando não perguntamos a um médico acerca da eficácia de determinado medicamento que fora produzido por cientistas em seus laboratórios. Entretanto, a utilização desses conceitos vem sendo questionada há algum tempo, pois o indivíduo cartesiano, projetor desse ideário, deixa de ter a centralidade e unidade que lhe era atribuída (Hall, 2006).

Um desses questionamentos envolve diretamente as mudanças políticoeconômicas que ocorreram no mundo durante do século XX e que afetam diretamente a construção epistemológica. Com novos centros de poder econômico fora do eixo Europa - América do Norte, com o avanço da tecnologia informacional e um crescente número de mobilizações sociais, ocorreu também um descentramento do pensamento científico.

De acordo com Santos (2010) a manutenção do pensamento científico moderno, ao qual ele classifica como dominante, percorre o mesmo caminho que o da dominação sociopolítica. Sua ascensão e manutenção estariam ligadas diretamente ao movimento colonizador que ocorreu no mundo durante os últimos séculos, com predominância de alguns países europeus e, mais recen- 
temente, dos Estados Unidos, e que resultou na atual divisão geopolítica. No seu entendimento,

"o colonialismo, para além de todas as dominações por que é conhecido, foi também uma dominação epistemológica, uma relação extremamente desigual entre saberes que conduziu à supressão de muitas formas de saber próprias de povos e nações colonizados, relegando muitos outros saberes para um espaço de subalternidade" (Santos, 2010, p. 11).

O pensamento científico moderno teve início e se desenvolveu ancorandose nas chamadas ciências naturais, que tinham entre seus paradigmas a separação entre sujeito e objeto e entre natureza e sociedade, a diminuição da complexidade a leis que pudessem ser provadas matematicamente e o reconhecimento do saber científico como verdadeiro em detrimento do senso comum e das humanidades. Somente no século XIX, os estudos sociais passaram a utilizar dos métodos e técnicas das ciências naturais e, com isso, passaram a compartilhar o status de ciência. E, é a partir do estabelecimento de relações entre as duas ciências, que se constitui um modelo global de racionalidade científica (Santos, 1995, p. 10).

De acordo com Santos (Idem, p.11) essa racionalidade científica instituiu um modelo totalitário o qual nega os conhecimentos que não atendem aos seus princípios epistemológicos e metodológicos. Os cientistas modernos atraíram para si a autoridade sobre a construção do pensamento racional e científico por meio da afirmação dos seus conhecimentos sob seus contemporâneos e, com isso, estabeleceram seu lugar na sociedade (Ibidem).

Entretanto, como dito anteriormente, o pensamento científico moderno, embasado nos preceitos e modelos definidos pelas ciências naturais, começa a enfrentar uma crise já no início do século XX, tanto pelas novas condições sociais que passam a existir quanto pelo avanço tecnológico resultante destes próprios estudos científicos. Santos (1995) utiliza quatro avanços das pesquisas nas ciências naturais para validar seu pensamento.

O primeiro passo para o entendimento dessa crise é identificar que o próprio conhecimento propiciado pelo paradigma científico moderno permitiu reconhecer que nele há limites e que os pilares aos quais eles são estabelecidos são frágeis. Para isso o autor utiliza como exemplo a teoria da relatividade e simultaneidade, de Einstein, que se opõe à teoria do tempo e espaço absolutos de Newton. O segundo ponto se refere à relação entre pesquisador e objeto pesquisado, a qual a microfísica de Heisenberg e Bohr mostrou que não é pos- 
A hegemonia científica e o senso comum na internet: uma análise segundo a Epistemologia do Sul de Boaventura de Sousa Santos

sível o primeiro observar o segundo sem qualquer tipo de modificação neste. O teorema da incompletude de Gödel, que contesta o rigor da matemática, acaba por questionar também o rigor das formalizações científicas, uma vez que estas tinham como base a matemática. Por fim, Santos (1995, p. 27) vê na teoria das estruturas dissipativas de Prigogine o quarto ponto de crise do pensamento científico moderno, uma vez que ela se contrapõe ao princípio da entropia das matérias fornecido pela física clássica.

Além desses pontos, Santos (1995, p.30) lembra que os pensamentos que originaram essa crise partiram de cientistas que buscaram uma compreensão filosófica para além dos seus conhecimentos físico-químico-biológicos, a fim de problematizarem suas próprias práticas científicas. E, como dito há dois parágrafos, as condições sociais e culturais passaram a ter significância e a ocupar um papel de destaque na reflexão epistemológica, o que nos remete ao domínio científico de países europeus, dos Estados Unidos, e do leste asiático. Neste sentido, tais países passaram a investir na industrialização da ciência, o que "acarretou o compromisso desta com os centros de poder econômico, social e político, os quais passaram a ter papel decisivo na definição das prioridades científicas" (Santos, 1995, p. 34). Com isso, a comunidade científica foi dividida e as relações entre os cientistas tornaram-se autoritárias e desiguais, o que levou a uma "proletarização no interior dos laboratórios e centros de investigação" (Idem, p. 35).

Pelo ponto de vista social, como cientista social que é, Santos (2006) enxerga na busca pela manutenção do pensamento científico moderno uma similaridade com o movimento político-econômico empreendido pelo capitalismo. Para ele, o colonialismo deixou suas marcas epistemológicas que não foram apagadas com o pós-modernismo. Aliás, o termo pós-modernismo, ligado diretamente ao momento em que vivemos e marcado por mudanças rápidas e constantes tanto do sujeito quanto das instituições sociais (Hall, 2006), é adotado por Santos em duas situações. Primeiro, em sua obra Um Discurso Sobre as Ciências (1995), publicada originalmente em 1985, na qual o autor o utiliza para definir um momento subsequente ao da ciência moderna em que um novo paradigma científico ${ }^{2}$ seria aplicado. Mais recentemente, em 2006, no livro $A$ Gramática do Tempo (2006), o conceito é ampliado para um viés social e po-

2. O paradigma de um conhecimento prudente para uma vida decente, o qual iremos abordar mais adiante. 
lítico e o termo vai buscar sua significância na crítica à modernidade ocidental de forma a compará-lo a um estágio pós-colonialista, onde somente os países do Atlântico Norte poderiam desfrutar dessa condição, embora que, para isso, ainda haja sofrimento humano nos países do Sul. Santos (2006, p. 27) propõe então uma "pós-modernidade de oposição" que combata a opressão social imposta pela pós-modernidade dos países dominantes.

Por outro lado, mesmo que o pensamento científico moderno busque se manter como dominante, sustentado por países de maior poder econômico e suas políticas de produção científica, Santos (2007, p. 25) irá defini-lo como indolente, dado ao seu posicionamento estanque em não se abrir para outros saberes. Como consequência dessa letargia, segundo Santos, haveria um desperdício de energia produtiva, pois se deixa de considerar que muitas coisas significativas para a ciência ocorrem no presente porque se vislumbra um futuro o qual os cientistas já conhecem: o progresso. Isso resultaria no que ele classifica como Sociologia das Ausências, que tenta "mostrar que o que não existe é produzido ativamente como não existente, como uma alternativa não crível, como uma alternativa descartável, invisível à realidade hegemônica do mundo" (Santos, 2007, p. 28-29).

Santos (2007) encara a construção das Ausências tal qual um modelo de monoculturas, pois, metaforicamente, elas apenas iriam extrair aquilo que o meio-ambiente pode oferecer sem que haja um trabalho de preservação. Há cinco monoculturas que contribuem para a manutenção das Ausências: monocultura do saber e do rigor, na qual o saber científico é o único que tem validade e o rigor metodológico para definir aquilo que é crível; monocultura do tempo linear, na qual persiste a ideia de uma linearidade histórica e que os países desenvolvidos estão à frente dos demais; monocultura da naturalização das diferenças, que encara diferenças étnicas, raciais, de classe social, de gênero como diferenças e não como igualdade, por meio da hierarquização e inferiorização; monocultura da escala dominante, na qual a racionalidade dominante é a do universalismo e da globalização, no sentido de que ambos desacreditam as realidades locais em favor dos pensamentos globais e universais; por último, a monocultura do produtivismo capitalista, na qual o ciclo da natureza e o trabalho humano são enquadrados dentro de uma lógica produtivista que descarta todo o restante que compõe o ser humano e o meio ambiente. 
A hegemonia científica e o senso comum na internet: uma análise segundo a Epistemologia do Sul de Boaventura de Sousa Santos

Todos estes aspectos que envolvem o pensamento científico moderno e sua relação com a manutenção de uma racionalidade que insiste em se manter dominante no atual formato social do mundo, compõem aquilo que o pensamento de Boaventura de Sousa Santos define como uma Epistemologia do Norte. Isso porque ela está diretamente ligada aos países que estão localizados geograficamente no Atlântico Norte, muito embora nem todos eles desfrutem do mesmo patamar socioeconômico e científico, como o próprio autor ressalta. Em contraposição à Epistemologia do Norte, Boaventura propõe uma Epistemologia do Sul, que, a princípio, tal qual à sua antagonista, não se restringe aos países do Sul geográfico, mas sim, a uma racionalidade emergente com vistas a um combate à supressão de saberes exercida pelo pensamento dominante. Essa divisão entre o pensamento científico ocidental e as epistemologias do Sul, Santos (2010) metaforicamente caracteriza como um abismo. De acordo com ele, essa linha estabelece que o conhecimento produzido no Sul seja considerado inexistente pelo Norte, pois a este só interessa o que é produzido por ele.

Dentro do contexto das Epistemologias do Sul, o primeiro ponto a se considerar é a própria relação epistemológica entre o pensamento científico moderno e o proposto por Santos (1995). Como dito acima, o pensamento científico moderno começou a entrar em uma crise a partir do momento em que os próprios cientistas passaram a buscar alternativas para romper com os limites que essa racionalidade impunha a si mesma. Para tal, Santos (Idem) vislumbra um paradigma emergente, o qual ele classifica como um "paradigma de um conhecimento prudente para uma vida decente" (ibidem, p. 37), pois se trata de uma construção epistemológica edificada em sociedade a partir da revolução promovida pela ciência. Ou seja, esse paradigma não deve ser apenas científico, mas também social.

O primeiro ponto para o estabelecimento desse paradigma é reconhecer que todo conhecimento científico-natural também é científico social. Para Santos (1995, p. 37) não há mais separação entre as ciências humanas e naturais, pois como ele próprio defende, a ciência atual é construída dentro de uma sociedade modificada por ela. Ora, mesmo as ciências naturais são concebidas hoje em dia em contextos sociais que não podem ser descartados. A dicotomia existente na separação entre estes dois tipos de ciências - naturais e sociais - deve ser rompida por ambos os lados. 
A segunda característica desse paradigma emergente busca eliminar as barreiras da disciplinarização dos saberes estabelecendo que todo conhecimento local é, também, total. Para Santos (1995, p. 46) o conhecimento disciplinar segrega, ao passo que estabelece fronteiras entre os saberes que não podem ser transpostas, e transforma o cientista em um especialista ignorante. Em contrapartida, o que o autor propõe é que essa fragmentação de conhecimentos seja posta de lado em prol de um saber total, separando não mais em disciplinas, mas em temas (Idem, p.47).

A quebra das fronteiras das disciplinas e a ampliação das áreas de conhecimento irá afetar diretamente o trabalho dos cientistas, que passarão a ter seus trabalhos mais personalizados, o que resultará no terceiro ponto da proposta de Boaventura: todo conhecimento é autoconhecimento (Santos, 1995, p. 50). Uma vez que o resultado do trabalho dos cientistas é tido como suas criações e que não se concebe mais uma separação entre sujeito e objeto de pesquisa, passa a existir a necessidade de reflexão sobre estes, pois "o objecto é a continuação do sujeito por outros meios" (Idem, p. 52).

Por fim, esses três pontos devem resultar na quarta característica do paradigma emergente, a qual todo conhecimento científico deve buscar se constituir como senso comum. Isso porque o paradigma científico emergente reconhece que, no senso comum, há virtudes que podem contribuir com o conhecimento científico, e vice-versa, para que ambas colaborem para uma melhor relação do ser humano com o mundo (Santos, 1995, p. 55-56).

Para se diminuir a indolência do pensamento científico moderno e romper o abismo que se estende entre Norte e Sul, deveríamos promover a realização desse paradigma estabelecendo um diálogo entre a ciência e os saberes por ela negados. Para isso, Boaventura propõe adotarmos uma Sociologia das Emergências (Santos, 2006) formada por ecologias que atuem contra as monoculturas que geram ausências.

A primeira é a ecologia de saberes, na qual, o importante "não é ver como o conhecimento representa o real, mas conhecer o que determinado conhecimento produz na realidade: a intervenção no real" (Idem, p. 33); com a ecologia da temporalidade devemos reconhecer que existem outros tempos que devem ser respeitados e que vão contribuir com a ampliação da nossa contemporaneidade; com a ecologia do reconhecimento podemos mitigar as diferenças até que restem apenas aquelas que não possam ser descartadas; na ecologia da transescala os projetos são articulados e os fenômenos analisados 
A hegemonia científica e o senso comum na internet: uma análise segundo a Epistemologia do Sul de Boaventura de Sousa Santos

em escalas locais, nacionais e globais; e com a ecologia das produtividades recuperaremos a valorização dos sistemas de produção alternativos e de projetos de economia popular e solidária.

Como dito ao longo desta comunicação, o grande objetivo a ser alcançado com o estabelecimento de um paradigma científico emergente é fazer com que o saber oriundo da ciência possa ser utilizado para uma vida melhor. Boaventura de Sousa Santos dentro da proposta da ecologia dos saberes (Santos, 2006, p. 46), nos diz que a universidade ainda é a grande produtora desse conhecimento e que seria ideal que elas realizassem uma extensão às avessas: ao invés de a universidade levar o conhecimento para a sociedade, esta trazer outros saberes para dentro da universidade. Entretanto, o que pode ser visto ainda nos dias atuais é um constante embate entre essas duas formas de saber, o senso comum e a ciência, cada uma tentando, a todo custo, desqualificar a outra por meio dos seus princípios. É o que iremos ver a seguir, com um exemplo retirado de um blog sobre jardinagem e paisagismo.

\section{Análise}

O blog Jardim das Ideias (www.jardimdasideias.com.br), se apresenta como um espaço para os amantes da jardinagem. Ele é mantido por uma empresa multinacional fabricante de máquinas e equipamentos para o trabalho florestal, agrícola e de jardinagem doméstica. Pelo copyright registrado no site, o Jardim das Ideias está no ar desde o ano de 2009 e oferece algumas funcionalidades para seus visitantes, como biblioteca de espécies, vídeos e concursos, entre outras. Eis a página inicial do blog ${ }^{3}$.

O post, objeto de nossa análise, foi publicado no dia 15 de setembro de 2009 e tem como tema o controle da expansão de liquens nas árvores. Até o dia 14 de janeiro de 2014, essa postagem recebeu um total de 91 comentários, 11 deles repetidos possivelmente por erro no seu sistema de inserção. Todos os comentários são nomeados, o que permitiu que realizássemos uma catalogação para identificar participações recorrentes. Com isso, constatamos a intervenção de 27 leitores, além do autor da informação e do especialista ${ }^{4}$.

3. Atualmente a página passou por mudanças estéticas e apresenta um layout diferente.

4. Iremos nomear o autor da informação apenas por "Autor", bem como o especialista será denominado por "Especialista", e os leitores "Leitor N" (onde N é determinado pela ordem cronológica de participação, indo de 1 a 27), pois, no nosso entendimento, tratá-los pelos seus 


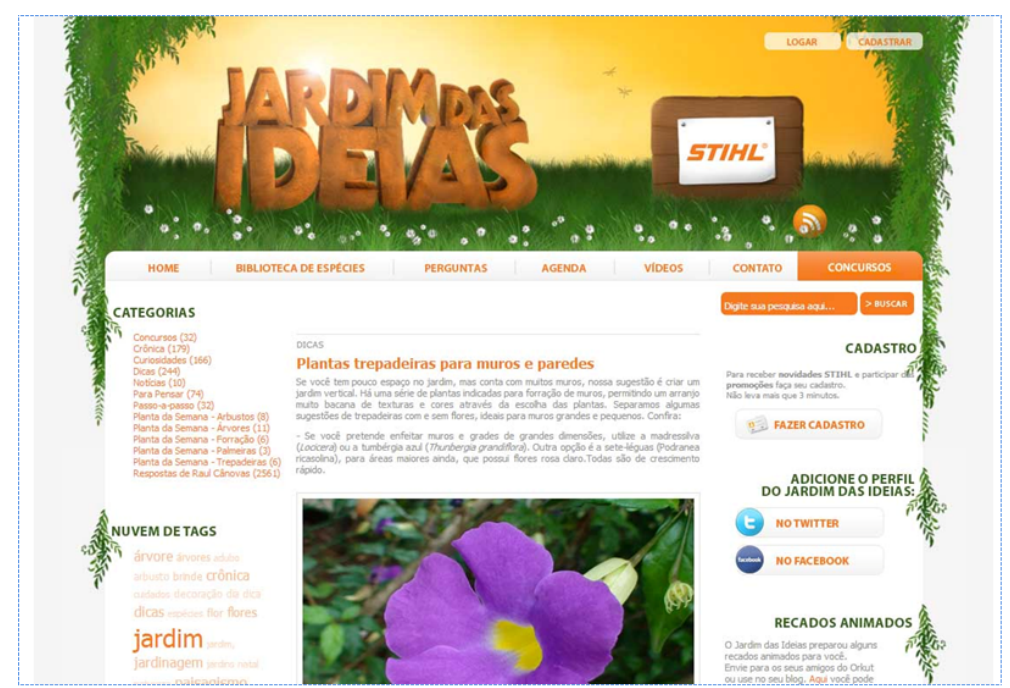

Figura 01. Homepage do blog Jardim das Ideias. Acesso em 10/02/2014.

\section{Segue a transcrição da informação veiculada ${ }^{5}$.}

Como controlar a expansão dos liquens nas árvores

Os liquens são organismos formados pela associação de um fungo com uma alga e aparecem colados em todo tipo de superfície: telhas, troncos, pedras, na terra e nas estátuas que estejam localizadas em locais sombreados pelas copas das árvores. Habitam dos trópicos ao ártico, onde não cresce praticamente nada.

Olhando através de um microscópio, um pedacinho de líquen, observamos duas plantas distintas: uma alga verde, ou levemente azulada e um fungo que tem filamentos rodeando a superfície dura da alga. Esta alga tem clorofila, por isso produz energia que recebe do sol e a divide com o fungo que fornece alimento mineral e abrigo. Esta parceria permite que o líquen viva milhares de anos.

nomes iria nos propiciar realizar e gerar juízos de valores sobre eles enquanto seres humanos e desviar o foco da nossa análise, que é a relação entre duas formas de conhecimento: o científico e o senso comum. A diferenciação entre a utilização de iniciais maiúsculas e minúsculas se dará em substituição dos nomes próprios de ambos para indicar que naquele ponto houve fala direcionada.

5. Disponível em www.jardimdasideias.com.br. Acesso em 10/01/2014. 
A hegemonia científica e o senso comum na internet: uma análise segundo a Epistemologia do Sul de Boaventura de Sousa Santos

São mais ou menos trinta mil variedades que vivem em todas as situações imagináveis: no deserto, na mata, na água doce, nas rochas à beira mar, e para alimentar-se retiram nutrientes de qualquer lugar, inclusive do vento.

Às vezes são um tanto abusados e cobrem quase que totalmente os troncos de arbustos e árvores. Nesse caso, para evitar a asfixia da planta , é aconselhável controlar sua expansão limpando o tronco e os galhos com uma escova dura, de nylon ou de arame ou ate com uma luva áspera de carneiro. Quando as infestações tomaram conta de uma superfície maior da árvore, pode-se passar pasta bordalesa na região com uma brocha. (Grifo nosso).

Na informação o autor descreve um pouco sobre o que são os liquens, onde e como eles vivem. Entretanto, ao final ele expõe que a cobertura excessiva desse microrganismo em um tronco de árvore pode levar à asfixia da mesma. Esse trecho, destacado no texto acima, é o qual iremos nos concentrar.

O diálogo por meio dos comentários teve início em outubro do mesmo ano. Entretanto, a primeira participação que questionou a informação veiculada pelo autor foi publicada no mês de janeiro de 2010. Nele, a Leitora 03 questiona "Como um líquen asfixia uma árvore??". A utilização de dois pontos de interrogação denota a uma pergunta retórica por parte dela. No entanto, a resposta do autor se restringe a reescrever o trecho o qual destacamos acima, sem qualquer explicação de "como" isso ocorre.

A primeira participação do Especialista ocorre no mês de agosto desse mesmo ano. Nela, ele questiona o conhecimento do autor acerca daquilo que ele informa por meio de explicações sobre a fixação dos liquens nas árvores e dizendo que não há a necessidade de qualquer tratamento para combatê-los. Poucos dias depois, eis a resposta do autor:

Você tem razão (pelo menos em parte) Especialista;

Os liquens são epífitos que não procuram o alimento de seus hospedeiros, não tendo qualquer relação com as parasitas. Entretanto, e sempre há um, entretanto, não apenas as parasitas comprometem o desenvolvimento das espécies lenhosas. Você já viu uma palmeira-acuri (Attalea phalerata) sendo abraçada até a morte por uma figueira-mata-pau (Ficus guaranitica), no Pantanal Mato-grossense? Percebeu o avanço avassalador de uma trepadeira conhecida como coração-de-estudante (Thunbergia grandiflora) em cima de um ipê-amarelo-cascudo (Tabebuia chrysotricha) que tenta em vão soltar suas folhas em setembro e não consegue 
porque essa planta o afogou por completo? Soube da invasão do cajepute (Melaleuca quinquenerva) na Florida, USA, massacrando a flora nativa desse bioma? O que acha desses exemplos onde alguma coisa escapa ao controle e destrói outra forma de vida vegetal?

Pois bem meu caro Especialista, a mesma coisa acontece quando o líquen-prateado (Parmelia carperata) se reproduz de modo continuado, graças à ação do vento, tomando os troncos e os ramos das árvores que não conseguem vegetar e entram em uma fase senescente, porque as brotações não podem competir com essas formas de vida. As árvores morrem, literalmente, asfixiadas. Isto foi constatado por mim na cidade de Suzano-SP, onde vi morrer uma alameda de tulipeiras (Spathodea nilotica) totalmente cobertas por esse líquen. Nessa região é comum ver outras espécies sofrerem com a presença de liquens: azaléias e outros arbustos definham por causa deles.

A calda bordalesa não é um procedimento agressivo é, apenas uma forma de controlar a expansão do líquen, como foi referido na minha matéria. Dou também parte de razão a você quando diz que desconheço o assunto; realmente não sou liquenólogo, sou apenas um paisagista que convive com o mundo vegetal há mais de meio século e isto me permite contemplar a paisagem de um modo menos pontual, desde um prisma ecosófico, onde procuro aproximar a ecologia ao pensamento abstrato dos homens que procuram algo além do pensamento cartesiano, que nos impede de sentir, obrigando-nos a racionalizar de forma cética.

Mas, enfim Especialista, agradeço suas colocações e espero que algum dia possa considerar-me seu colega.

Abraços,

No primeiro parágrafo do comentário-resposta, o autor utiliza dos nomes científicos de algumas plantas para expor seu conhecimento sobre o assunto, em resposta à desqualificação do comentário anterior. Em seguida, o autor explica o "como" solicitado no comentário da outra leitora, e justifica a ocorrência do fato por meio de um exemplo por ele acompanhado. Já no terceiro parágrafo, ele expõe sua atividade como paisagista com vasta experiência ("há mais de meio século") e utiliza isso para confrontar o conhecimento acadêmico, nesse período representado pelo "pensamento cartesiano" que obriga os cientistas a pensarem de forma cética.

Neste ponto há o primeiro embate entre o discurso científico e o senso comum. Em sua resposta, mais especificamente sobre o caso das tulipeiras mortas na cidade de Suzano (SP) ele apresenta como único argumento o excesso 
de liquens nas árvores, porém sem considerar a existência de outros fatores que pudessem ter influência sobre o fato, como, por exemplo, deficiência de adubação do solo.

Em resposta ao autor, o especialista afirma que

Prezado Autor

O número de coisas absurdas que você mencionou é muito problemático. Eu sou um dos poucos especialistas em liquens do Brasil, tenho Mestrado e Doutorado em liquenologia (trabalho na Secretaria do Meio Ambiente do Estado de SP, no Instituto de Botânica), conheço Parmelia caperata muito bem assim como outras 2514 espécies até o momento, e posso garantir que a cobertura de um trono por liquens, seja ela total ou parcial, NADA tem a ver com a morte de um vegetal. Nenhuma de suas estruturas penetra na casca mais que o suficiente para se fixar sobre ela, isso quando penetra, e toda a nutrição vêm da relação simbiótica e do ambiente, tal como a poeira mineral que percola da copa ao tronco quando chove ou é trazida pelo vento.

EU posso GARANTIR que nada do que você disse é verdade. É uma alegação sua baseada numa observação e conclusão sem NENHUM fundamento científico! "a, os liquens cobrem as plantas, então por isso elas estão morrendo!"

Isso é simplesmente ABSURDO!!!pelo amor de Deus, não divulgue isso a leigos! Se você não conhece a biologia de um organismo, não deve tirar conclusões precipitadas sobre elas.

Note que estou falando dos liquens, e não de outros grupos de fungos, como os que o senhor mencionou no primeiro parágrafo.

A propósito, o nome atual do liquen prateado que o senhor mencionou é Parmotrema caperatum, e dessa família constam atualmente mais de 2500 espécies. Tem idéia do nivel do seu desconhecimento? Num tronco de árvore isolado, eu já cheguei a identificar mais de 120 espécies de liquens. O recorde de que já ouvi falar é 187.

Eu até quero ajudar você, mas por favor, não divulgue algo sem antes consultar um especialista! Você faz idéia de quantos alunos nos procura todos os anos querendo fazer iniciação científica, mestrado ou doutorado com liquens como bioindicadores ou biomonitores?

Um abraço.

Neste comentário, o especialista busca reafirmar a posição do saber científico em detrimento ao senso comum. Ele utiliza seus títulos acadêmicos e 
expõe seu lugar de trabalho - em um centro de pesquisa - para conferir autoridade à sua fala. Ele ainda explica o modo de fixação de uma espécie em outra para contrapor o raciocínio do autor, o qual, segundo ele, não atende fundamentos científicos. Como o diálogo se estabelece por meio da escrita, o especialista utiliza algumas palavras em letras maiúsculas, um recurso comum no meio digital que remete a uma entonação forte da voz. No terceiro parágrafo, o especialista demonstra preocupação na divulgação de uma informação que não foi comprovada cientificamente para o público, o que reforça a sua ideia de institucionalização do saber para que este seja validado.

Para além dessas primeiras percepções visualizadas individualmente, o que podemos presenciar neste pequeno trecho do diálogo entre autor e especialista, e entre eles e nós, leitores, é um discurso no qual é possível notar o que Orlandi (2007, p. 39) define como o estabelecimento de uma relação de forças. Isso porque cada enunciador utiliza do seu lugar de fala - o primeiro como jardineiro experiente e o segundo como especialista titulado - para fazer provar seu ponto de vista. Neste sentido, de um lado notamos a afirmação da ciência enquanto única forma de conhecimento capaz de revelar a verdade das coisas, enquanto que de outro vemos uma corrente de pensamento que questiona essa posição.

Notamos ainda como a relação de sentidos é constituída. Como dito antes, a conversa entre os dois protagonistas remete ao embate entre conhecimento científico e senso comum, o que, no nosso ponto de vista, não significa uma disputa pessoal entre os dois indivíduos envolvidos, mas sim uma disputa simbólica, sócio-histórica e ideológica, que é responsável pelo sentido amplo ao qual este discurso foi produzido (Orlandi, 2007, p. 30). Nesse caso, também podemos observar a presença de um esquecimento ideológico (Idem, p. 35), pois cada enunciador retoma sentidos pré-existentes que lhes significam de acordo com seus posicionamentos na sociedade.

A busca em referências outras para legitimarem seus discursos perante o debatente - o autor em sua experiência de "mais de meio século" e o especialista em sua formação institucional - remete, ainda, à vontade de afirmarem seus discursos como verdadeiros (Foucault, 1999) e, por assim, adquirirem algum poder para ser exercido sobre o interlocutor. É claro que, no caso do especialista esse exercício da vontade de verdade vai ser mais latente, uma vez que a própria ciência, institucionalizada, tal como relata Foucault (Idem, 
A hegemonia científica e o senso comum na internet: uma análise segundo a Epistemologia do Sul de Boaventura de Sousa Santos

p. 17), tem inúmeros mecanismos para apoiar sua posição, como livros, laboratórios, congressos, etc.

Tais defesas de locais de fala fazem com que, ao longo do debate entre autor e especialista, os leitores tomem posições por um ou por outro ${ }^{6}$. O que se vê por meio das falas dos leitores é a mesma construção de sentido dos protagonistas. Alguns dos que defendem o autor o fazem por este ter um passado prático que os remetem a um conhecimento real, ao mesmo tempo em que subestimam o conhecimento acadêmico. A exemplo da Leitora 08, que diz: "Eu prefiro acreditar no Sr. Autor e salvar minhas plantas, do que acreditar no Dr. Especialista e ficar vendo minhas plantas morrerem". Por outro lado, os que defendem o local de fala do especialista o fazem sustentando o conhecimento acadêmico, como este trecho do comentário da Leitora 10, descrito abaixo:

“[...] Vou mandar um recado a você e as pessoas que acreditam em você, procurem estudar, porque tudo o que esta escrito neste artigo nao passa de baboseira. Liquens não fazem mal a planta, FUNGOS sozinhos é que fazem, e ALGUMAS espécies de fungos.. como orelha de pau, ai sim vocês deverão se preucupar com suas plantas. OS LIQUENS SAO BIOINDICADORES DE POLUIÇÃO, ELES NOS AJUDAM A VERIFICAR A QUALIDADE DO AMBIENTE OK?! [...]"

Em dado momento, o autor deixa de responder aos comentários dos leitores e sua voz é substituída pela da instituição administradora do site que, em suas respostas conta com a "colaboração" de um engenheiro agrônomo. Em sua primeira participação efetiva, para sanar as dúvidas da leitora 16, a voz institucional passa a concordar com o especialista - no que se refere aos liquens não serem problemas para as árvores - e a recomendar aos leitores que não utilizem quaisquer métodos para controlarem os liquens. Mesmo assim, até a data de produção deste artigo, o texto original não havia sido modificado.

\section{Considerações}

Este embate entre o autor paisagista, de construção prática, e o especialista, com seu saber comprovado institucionalmente pela academia, figura apenas como exemplo das divergências entre o conhecimento oriundo do saber científico e o advindo do senso comum, abordadas pelo pensamento de

6. Devido ao espaço deste artigo não será possível detalhar as participações dos leitores, o que engrandeceria essa comunicação. 
Boaventura de Sousa Santos. Tal qual o movimento colonialista, o conhecimento científico abarca em um território e se impõe através dos seus paradigmas e da sua trajetória sócio-histórica.

Vemos de forma nítida o exercício de uma monocultura do saber e do rigor ligada diretamente à manutenção de uma epistemologia dominante, que se solidifica a partir do momento em que o ator empirista é substituído pelo ator institucional, bem como da vontade de verdade, ao passo que este utiliza um discurso similar ao do especialista. Com isso, percebemos também que há uma busca por dominação político-social para além da epistemológica, uma vez que, ao institucionalizar a palavra, os administradores objetivam ter credibilidade junto aos dois públicos - aos leitores prestando auxílio em seus questionamentos e embasando suas respostas com a voz de um 'engenheiro', profissão que transmite maior credibilidade em assuntos "técnicos" em nossa sociedade; e ao público especialista, que terá seu discurso verificado como verdadeiro por um representante do meio acadêmico.

Entretanto, a institucionalização do conhecimento acaba por diminuir o diálogo com os outros saberes que poderiam emergir de um diálogo produtivo entre a ciência e o senso comum, uma vez que muitos conhecimentos não foram catalogados. Essa supressão do saber do senso comum acaba por reforçar a ideia de existência de um abismo que o separa do conhecimento científico.

Do outro lado, porém, observamos que a construção de um espaço para discussão de assuntos do cotidiano, neste caso relativos à natureza, é um exemplo de um caminho que pode ser utilizado para se promover o paradigma emergente (Santos, 1995) em todas as áreas do conhecimento. Inserir temas de ambos os lados, da ciência e do senso comum, para debates e apreciações pode ser positivo tanto para a academia, que terá mais um caminho para conversar com a sociedade, quanto para o povo, que pode dialogar com outros saberes e trocar experiências. Entretanto, essa conversação deve ser realizada tendo em vista que os objetivos não são provar-se frente ao outro, mas colaborar para uma construção de um saber que torne a vida mais decente.

\section{Referências}

Alves, R. (1981). Filosofia da ciência: introdução ao jogo e suas regras. São Paulo: Brasiliense.

Foucault, M. (1999). A ordem do discurso. São Paulo: Loyola. 
A hegemonia científica e o senso comum na internet: uma análise segundo a Epistemologia do Sul de Boaventura de Sousa Santos

Hall, S. (2006). Identidade cultural na pós-modernidade. Rio de Janeiro: DP\&A.

Orlandi, E.P. (2012). Análise de discurso: princípios \& procedimentos. Campinas: Ponte.

Santos, B.S. (1995). Um discurso sobre as ciências. Lisboa: Afrontamento.

Santos, B.S. (2006). A gramática do tempo: para uma nova cultura política. São Paulo: Cortez.

Santos, B.S. (2007). Renovar a teoria crítica e reinventar a emancipação social. São Paulo: Boitempo.

Santos, B.S. (2010). Para além do pensamento abissal: das linhas globais a uma ecologia de saberes. In B.S. Santos \& M.P. Meneses. (Orgs). Epistemologias do Sul. São Paulo: Cortez. 
$\bigoplus$

$\bigoplus$

$\oplus$ 


\title{
Comunicação, Ideologia e Ciência: questões epistemológicas e metodológicas
}

\author{
Rakel de Castro \& Heitor Costa Lima da Rocha \\ Universidade Federal de Pernambuco \\ E-mail: patriciascastro@hotmail.com/hclrocha@gmail.com
}

\begin{abstract}
Resumo
Este artigo faz um review crítico-interpretativo tentando estabelecer uma relação entre a Comunicação e a Ciência, tomando por base algumas características comuns a ambas manifestações humanas como a concretização da linguagem e o caráter opaco/ideológico, utilizando concepções críticas de Wittgenstein, Habermas, Schutz, Piaget e Ricoeur, bem como as fundamentações pragmáticas de Mead e Peirce para refutar as con-

cepções positivistas da teoria da verdade como correspondência e da objetividade mitificada que desvalorizavam a comunicação e a ação humana na construção social da realidade. Para tanto, também buscou-se aplicar na metodologia científica uma valorização da pesquisa qualitativa como ferramenta de pesquisa necessária ao entendimento da Comunicação conforme a epistemologia do paradigma construtivista de ciência.

Palavras-chave: Comunicação; ciência; ideologia; linguagem.
\end{abstract}

\begin{abstract}
This article is a critical-interpretive re- tic conceptions of the theory of truth as view trying to establish a relationship correspondence and mythical objectivity between Communication and Science, that devalued the communication and hubased on some characteristics common to man action in the social construction of both human manifestations as the reali- reality. For this, also aimed to apply scization of language and opaque / ideolo- entific methodology in an appreciation of gical character, using criticism views of qualitative research as a study tool necesWittgenstein, Habermas, Schutz, Piaget sary for the understanding of communiand Ricoeur, as pragmatic foundations of cation as the epistemology of constructiMead and Peirce to refute the positivis- vist paradigm of science.
\end{abstract}

Keywords: Communication; science; ideology; language. 


\section{Introdução: Para pensar a opacidade da comunicação}

$\mathrm{O}$ estudo da comunicação sob a perspectiva crítica da Filosofia da Linguagem surge com os estudos de Ludwig Joseph Johann Wittgenstein, mas se desenvolve com as contribuições de Jürgen Harbermas.

Segundo Danilo Marcondes (2000), Wittgenstein vai pensar uma linguagem como prática social concreta, mas acaba deixando de pensar uma teoria da linguagem que esteja integrada a uma teoria da sociedade que situe o papel dessa linguagem, uma teoria da ideologia que explique as distorções no uso da linguagem através de formas de dominação na sociedade e da maneira como essa dominação é reproduzida e justificada. "A preocupação de Wittgenstein é essencialmente analítica, voltada para o desenvolvimento de um instrumento de análise, a partir do uso concreto da linguagem e suas interações que o uso de seus termos e expressões envolvem e pressupõe". (Marcondes, 2002: 110).

A filosofia wittgensteiniana, então, se apresenta como uma superação do cientificismo ao reconhecer a importância dos conhecimentos compartilhados pelo ordinary people no mundo da vida. No entanto, é criticada exatamente por propor uma análise do significado de expressões a partir de seu uso comum em contextos determinados, o que teria feito Wittgenstein deixar de lado análises fundamentais à própria essência da linguagem.

O significado se daria través dos jogos de linguagem ${ }^{1}$, que seria os conjuntos heterogêneos da linguagem, com suas regras, convenções e finalidades próprias. Sendo muitos e variando de acordo com o contexto de uso em que os empregamos (para indagar, consolar, indignar-se ou descrever etc.), os jogos de linguagem seriam determinantes para elucidação do significado. Para

1. Wittgenstein traça uma analogia entre a noção de linguagem e a noção de jogo. Há diversos tipos de jogos: jogos de tabuleiro, jogos de cartas, competições esportivas, etc. Mas não há uma essência dos jogos. Um jogo de cartas apresenta semelhanças com os jogos de tabuleiros, mas também muitas diferenças; se compararmos esses últimos com os jogos de bola, surgirão outras semelhanças e outras se perderão. O que há é uma sobreposição de traços que Wittgenstein chama de semelhança de família. Numa família, alguns partilham a mesma cor do cabelo, outros partilham a mesma estatura, outros o tom de voz, etc. Mas geralmente não há característica que esteja presente em todos os membros da família. O mesmo ocorre com o conceito de "jogo". Chamamos práticas muito diferentes de "jogo" não porque haja uma definição exata que esteja implícita em todas as aplicações do termo, mas porque essas diversas práticas manifestam semelhança de família (Durante, 2013). Semelhantemente, as diversas práticas linguísticas são reunidas sob a denominação de "linguagem" em virtude de suas semelhanças de família. 
Comunicação, Ideologia e Ciência: questões epistemológicas e

saber, pois, o que significa uma palavra, a melhor estratégia seria descrever os traços mais evidentes desse jogo e revelar qual é o papel desempenhado pela palavra em questão (Wittgenstein, 2000).

Mas é aí que essa Filosofia da Linguagem incorre no mesmo problema que o da Semântica Formal: enquanto esta última afasta-se da linguagem tal como é usada, não sendo capaz de produzir nenhuma elucidação sobre o significado; a primeira não tematiza, em sua origem, o caráter opaco da linguagem em uso, produzindo, ambas, um conceito artificial, pois se não reconhecermos que a linguagem como uma forma de interação social, estruturadora da experiência, refletindo e reproduzindo as estruturas sociais e, portanto, as desigualdades, os conflitos, a manipulação etc., então estaremos igualmente trabalhando com um conceito de linguagem que marginaliza elementos essenciais de sua natureza (Marcondes, 2000).

Para transpor essa fragilidade do conceito, a Filosofia da Linguagem há de ter uma perspectiva mais crítica (estabelecendo mesmo uma metodologia crítica de análise), tematizando de alguma forma a questão da ideologia (caráter social), e não apenas se limitar às analises da linguagem em uso e a utilizar conceitos como contexto, convenção, falante/ouvinte etc.

É então que a Teoria da Ação Comunicativa, de Jürgen Habermas desenvolve esse conceito, interpretando a linguagem como objeto socialmente construído, como prática social concreta que reflete a estrutura da interação social. Assim se faz necessária uma análise das condições constitutivas do discurso possível. Essa análise parte de um conceito de linguagem como comunicação que se funda na noção de intersubjetividade: o uso da linguagem consiste em um ato de entendimento mútuo, levando necessariamente a um acordo fundamentado, justificado, ao qual se chega através do diálogo, através da possibilidade de se retomar, interrogar o discurso (Marcondes, 2000).

Marcondes (2000) explica que, para o autor alemão, nosso uso linguístico concreto é caracterizado por distorções nesta situação ideal, originárias da própria estrutura social, havendo desigualdades na distribuição dos papéis linguístico-sociais, nas regras do discurso e em seu controle. Estas distorções geram casos em que a situação ideal é fictícia, embora pareça real, as justificativas são apenas aparentes, os falantes apenas imaginam que controlam as regras. É dessa forma que se caracteriza linguisticamente a "manipulação ideológica". 
Por isso, conforme Habermas (1997), a importância de se formular uma situação ideal de linguagem: para distinguir o falso consenso do verdadeiro, em nome da qual se interpreta o discurso da manipulação ideológica, para fundamentar uma metodologia crítica e não apenas descritiva.

Essa metodologia crítica é feita a partir da Ação Comunicativa, de um conceito de interação visando o entendimento a cerca de uma situação compartilhada.

Primeiro, considera-se a natureza dialógica da linguagem, em que se reconstrói o discurso em geral (a rede principal de interações linguísticas) como um jogo que tem como um lance inicial uma tomada de posição do falante e tem como lance de resposta uma contraposição de seu interlocutor, sendo a regra do jogo a validação ou justificação dos lances. Assim a identidade do falante não pode ser considerada como originária e sim como formada, constituída como capacidade de realizar atos de fala, isto é, como tomadas de posição no jogo da linguagem. Os falantes se auto-identificam, portanto, através da realização de um ato de fala como tomada de posição (Marcondes, 2000).

Sobre o processo de identificação dos falantes/ouvintes, Marcondes detalha:

Essa identificação é aceita pelos ouvintes quando reconhecem a autoidentificação dos falantes. O consenso se produz na medida da capacidade de identificação recíproca entre falante e ouvinte. O pressuposto fundamental desse consenso é a existência de regras reconhecidas de justificação e validação dos lances. Dessa forma, a identidade do falante e do ouvinte pressupõe uma identidade coletiva do grupo social que aceita as regras e do qual ambos fazem parte (Marcondes, 2000: 116).

Neste trecho, o autor explicita como a Teoria da Ação de Habermas colabora para o desenvolvimento de uma Teoria Crítica da Filosofia da Linguagem: a partir dessa identidade dos falantes duplamente constituída (em primeiro lugar, como identidade convencional - coletiva -; em segundo, como identidade individual - a partir da possibilidade de recorrer à regras no uso da linguagem, o falante pode tomar a universalidade pretendida por toda regra de justificação para a interpretação de regras particulares -). 
Comunicação, Ideologia e Ciência: questões epistemológicas e metodológicas

Dessa forma, uma proposta crítica deve supor que, em algum momento e de alguma forma, existe a autonomia da razão individual. Deve considerar visões de mundo e formas de ação alternativas de realizar atos de fala (Marcondes, 2000).

\section{Intersubjetividade: a linguagem se concretizando enquanto comunicação}

Sobre a duplicidade e o consenso na construção da identidade dos falantes em um processo comunicativo, Rüdiger (2009) vai explicar que o sentido também remete analiticamente à orientação recíproca, que guia a conduta dos indivíduos dentro de certas condições; é uma propriedade intersubjetiva presente de um modo ou de outro, em maior ou menor grau, na conduta social, ainda que transcenda a consciência imediata.

Analogicamente, para Pierce, a comunicação entre locutor e auditor exige um "fundamento" ou "território" comum entre os interlocutores, para que possa concretizar-se, e este aspecto do universo partilhado acaba por remeter diretamente para a questão da fixação intersubjetiva do valor e moldura semântica dos termos de qualquer conversação. Além disso, uma situação interlocutiva é sempre inter, mas também intra-dialógica, devido ao aspecto de indeterminação ou vagueness da comunicação, que remete sempre para sucessivas reelaborações mentais no âmbito do processo de semiose ilimitada em que todo o sujeito se encontra envolvido (Gradim, 2011).

Em Schutz, há também um movimento de percepção que avalia o compartilhamento intersubjetivo de significados e o processo de significação, de objetificar conceitos (uma concepção da natureza humana e da sua relação com o mundo da vida que privilegia a intersubjectividade) como condições para que a linguagem se concretize enquanto comunicação, a qual "desempenha um papel estruturante nas manifestações concretas de sociabilidade" (Correia, 2004: 11).

Ainda tratando do caráter social da linguagem, Schutz apontava para uma abordagem que levaria em consideração não apenas o caráter intersubjetivo, mas também intencional que se dá na ação comunicativa.

João Carlos Correia (2004: 159) afirma que Schutz discute a comunicação como um tipo de ação que se dirige a outro com a intenção de dar a conhecer um significado. Ou seja, a ação comunicativa é uma ação social porque é dotada de significado subjetivo e dirigido a outros. Para além do significado 
que a mensagem carrega, existe um motivo para comunicar que ultrapassa esse significado. "A confusão com qualquer outra ação significativa é, pois, possível, porque toda a ação externa de tipo social apresenta um significado subjetivo que lhe é atribuído pelo ator, neste caso pelo falante". Porém, não permite que se dissolva o conceito de ação comunicativa no conceito de ação dotada de significado. "A intencionalidade na transmissão dos significados surge como o elemento essencial e característico dos processos comunicativos". Neste sentido, o comunicador não espera apenas uma compreensão do seu interlocutor, mas uma tomada de posição, uma atitude, conduta que é condicionada por essa compreensão e orientada para ela. "A comunicação é sempre finalista: espera sempre produzir um determinado efeito na pessoa a quem se dirige".

Essa propriedade intencional que faz parte da essência da comunicação, pensado por outros autores já citados como o caráter opaco, ideológico, também é ora analisado na comunicação enquanto da ciência.

\section{A opacidade também da Ciência}

Habermas (1968), analisando estudos de Hebert Marcuse, em "Técnica e Ciência como Ideologia", oferece um panorama pensado por seu colega de escola frankfurtiana e uma alternativa de superação de suas considerações que já apontavam para o caráter ideológico da ciência.

Marcuse foi inspirado pelo conceito de racionalização de Max Weber, que definia a ampliação das esferas sociais submetidas aos critérios de decisão racional. A isso correspondia à industrialização do trabalho social e como consequência a influência desses critérios de ação instrumental (critérios de decisão racional) em outras instâncias da vida (urbanização nas formas de existência, tecnificação do tráfego e da comunicação). Neste caso, a racionalização progressiva da sociedade depende da institucionalização do progresso científico e técnico. É então que Marcuse se convence de que naquilo que Weber chamou de racionalização não se implanta uma racionalidade, mas uma forma de dominação política oculta. Sobre essa forma de dominação, Habermas (1968), esclarece:

A racionalidade deste tipo só se refere à correta eleição entre estratégias, à adequada utilização de tecnologias e à pertinente instauração de sistemas (em situações dadas para fins estabelecidos), ela subtrai o 
entrelaçamento social global de interesses em que se elegem estratégias, se utilizam tecnologias e se instauram sistemas, a uma reflexão e reconstrução racionais. Essa racionalidade estende-se, além disso, apenas às situações de emprego possível da técnica e exige, por isso, um tipo de ação que implica dominação; quer sobre a natureza ou sobre a sociedade. A ação racional dirigida a fins é, segundo a sua própria estrutura, exercício de controles (Habermas, 1968: 46).

Assim, direcionando o conceito de ideologia para o caráter de ocultação da realidade e de dominação, segundo as análises de Habermas sobre a obra de Marcuse (o qual já se inspirara em Weber), a própria definição de razão técnica é, inclusive, ideológica. Portanto, não só aplicação da técnica em si mas também é dominação metódica, científica, calculada e calculante (sobre a natureza e sobre o homem).

Determinados fins e interesses de dominação não são outorgados à técnica apenas «posteriormente» e a partir de fora - inserem-se já na própria construção do aparelho técnico; a técnica é em cada caso, um projeto histórico-social; nele se projeta o que uma sociedade e os interesses nela dominantes pensam fazer com os homens e com coisas. Um tal fim de dominação é «material» e, neste sentido, pertence a própria forma da razão técnica (Habermas, 1968: 47) ${ }^{2}$.

Aqui já se deixava claro que a própria Ciência, enquanto reconhecida apenas pelo seu caráter técnico-racional, carregava desde a sua definição elementos ideológicas. Mais adiante, Habermas vai reconhecer em Marcuse, que o peculiar fenômeno de dominação nas sociedades capitalistas industriais avançadas tende a perder suas características de exploração e opressão, e torna-se "racional", sem perder o caráter ideológico político. Há então um entendimento sobre uma nova forma de legitimação da dominação: a referência à crescente produtividade e ao crescente domínio da natureza. Habermas (1968: 49) chega a afirmar que "hoje a dominação eterniza-se e amplia-se não só mediante a tecnologia, mas como tecnologia; e esta proporciona a grande legitimação ao poder político expansivo, que assume em si todas as esferas da cultura".

2. Trecho analisado por Habermas a partir da obra "Industrialisierung und Kapitalismus", de autoria de Max Webers, em Kultur und Gesellschaft, II, Francoforte, 195. 
O autor alemão relaciona a partir de então a técnica com a ação racional com respeito a fins e a partir daí, começa a enxergar um caráter também emancipador dessa técnica; pois que, ao lado da ação instrumental, Habermas vai pensar a coexistência de uma ação comunicativa e junto com ela as mutações emancipadoras do marco institucional entre questões técnicas e questões praticas. Habermas (1968) elucida:

A racionalização ao nível do marco institucional só pode levar-se a cabo no meio da interação linguisticamente mediada, a saber, pela destruição das restrições da comunicação. A discussão pública, sem restrições e sem coações, sobre a adequação e a desiderabilidade dos princípios e normas orientadoras da ação, a luz das ressonâncias socioculturais do progresso dos subsistemas de ação racional dirigida a fins - uma comunicação deste tipo em, todos os níveis dos processos políticos e dos processos novamente politizados de formação da vontade, é o único meio no qual é possível algo assim como a «racionalização» (Habermas, 1968: 88).

Para o autor (1968), uma racionalização que fosse avaliada pelas modificações através do decrescente grau de repressividade, do decrescente grau de rigidez e da aproximação a um tipo de controle de comportamento que permita a distinção de papéis e uma aplicação flexível das normas internalizadas, não leva a um incremento do poder de disposição técnica sobre os processos objetivados da natureza e da sociedade; mas sim geraria uma racionalização das normas sociais que dotaria os membros da sociedade com oportunidades mais amplas de emancipação e de uma progressiva individuação.

Assim, unindo o caráter opaco da linguagem, presente também na Comunicação e na Ciência, abre-se um parêntese neste artigo para se apostilar sobre outras nuances que o termo ideologia traz consigo.

Antes mesmo de configurar um aspecto negativo do conceito, ideologia deve ser entendida aqui também como pressuposto das relações vivenciadas pelo homem, e como tal, pode e deve ser alterada, modificada, reinventada, forjada. Dessa forma, as relações experimentadas e modificadas, oferecem, por conseguinte, os instrumentos necessários para uma constante mudança da sociedade, possibilitando sair da condição de dominação, mesmo que através de uma emancipação parcial e gradativa pressuposta numa busca aproximativa da universalidade. Ideologia assume um caráter não só de dominação (tam- 
bém, mas não só), de encobrimento do real, mas de processualidade para a autonomia dos sujeitos.

Em se tratando da natureza da relação entre ciência e ideologia, segundo Paul Ricoeur (1996), esta depende tanto do sentido que possamos dar ao conceito de ciência quando ao sentido que podemos estabelecer quando nos referimos à ideologia.

De fato, pensar que não se pode fazer crítica à ideologia simplesmente porque estamos situados em posições também ideológicas, pode parecer ingênuo e sem sustentação. Ricoeur (1996) vai dizer que o pesquisador que não possui pressuposições, não coloca questões, e quem não coloca questões não pode formular hipóteses e, ao mesmo tempo, nada mais procura.

Ocorre aqui com o pesquisador, o mesmo que se dá nas sociedades: as ideologias são distâncias, discordâncias referentes ao curso real das coisas. Mas a morte das ideologias constituiria a mais estéril lucidez. Porque um grupo social sem ideologia e sem utopia seria sem projeto, sem distância em relação a si mesmo, sem representação de si. Seria uma sociedade sem projeto global, entregue a uma história fragmentada em acontecimentos inteiramente iguais e, por conseguinte, insignificante (Ricoeur, 1996: 89).

Aqui o autor chama atenção para o caráter relacional e relativo da ideologia, sem torná-la relativista. Ressitua o conceito pensado parcialmente para apresentar um pensamento mais global. Somente quem estiver inteiramente consciente do alcance limitado de todo ponto de vista, encontra-se no caminho da compreensão procurada do todo (Mannheim apud Ricoeur, 1996: 90).

Dessa forma, o autor francês aponta algumas proposições sobre a relação ciência - ideologia. A primeira delas diz respeito a relação de pertencimentos que todos os humanos prescindem e que jamais poderão refletir inteiramente sobre isso, porque sua fala sempre vai denunciar um lugar, um contexto. Pretender isso, arriscar-se-ia cair na armadilha do absoluto e não é essa a intenção ao se falar de ideologia, quanto mais de ideologia num sentido mais críticoneutro.

Antes de qualquer distância crítica, pertencemos a uma história, a uma classe, a uma nação, a uma cultura, a uma ou a tradições. Ao assumir essa pertença que nos precede e nos transporta, assumimos o primeiro 
papel da ideologia, o que descrevemos como função mediadora da imagem, da representação de si. Pela função mediadora das ideologias, também participamos das outras funções: funções de dissimulação e de distorção. Todavia, sabemos agora que a condição ontológica de pré-compreensão exclui a reflexão total que nos colocaria na situação privilegiada do saber não-ontológico. (Ricoeur, 1996: 92).

Ainda segundo ele, não dá para se pensar os intelectuais sem amarras ou pontos de apoio, mas estes precisam continuar a ser "transportados por aquilo que Hegel chamou de substância ética". A ideologia seria então o código de interpretação da ciência. Complementando o pensamento, outras proposições sugeridas por Ricoeur (1996: 92) dizem respeito à autonomia dos sujeitos. "Se o saber objetivante é sempre segundo relativamente à relação de pertença, não obstante, pode constituir-se numa relativa autonomia".

Com efeito, o autor acaba aferindo na ciência o caráter ideológico, sob o viés do contexto histórico e social. "Nada nos é mais necessário, em nossos dias, que a renúncia à arrogância da crítica, para empreendermos, com paciência, o trabalho incessantemente retomado do distanciamento e do assumir de nossa condição histórica"(Ricoeur, 1996: 95).

\section{A Ideologia Social e a Ideologia Epistêmica}

Jean Piaget e Garcia (2011) fazem uma refutação categórica da presunção positivista da avaloratividade científica, ao observar a influência exercida pela ideologia social na definição do aparelho conceitual e do conjunto de teorias que constituem a ciência aceita em determinado momento histórico e num mesmo quadro epistêmico, direcionando a pesquisa científica. Neste sentido chamam a atenção para fato de que algumas linhas de pesquisa destacam-se e outras encontram pouco ou nenhum apoio, enquanto alguns temas tornam-se moda em detrimento de outros.

Neste sentido, salientam Piaget e Garcia (2011: 337) que a definição das linhas de pesquisa sofre estímulos ou pressões de setores sociais: é o caso da tecnologia aplicada à indústria, "cujo desenvolvimento ocasionou descobertas fundamentais que abriram novos campos de pesquisa científica. A tecnologia militar tem sido talvez o exemplo mais característico”. 
É possível imaginar que, se os estímulos tivessem sido diferentes, outros campos da ciência poderiam ter sido objeto de uma maior atenção por parte dos melhores pensadores do nosso tempo, outras descobertas teriam sido realizadas e outras teorias científicas teriam nascido para explicá-las. Um grande setor do conhecimento científico continua assim a ampliar-se, não de forma estritamente racional, respondendo a uma problemática interna, mas de um modo algo arbitrário e graças a um conjunto de disposições orientadas por exigências externas impostas pela sociedade. É por isso que designamos o tipo de paradigma assim condicionado por "paradigma social" (Piaget; Garcia, 2011: 337 - 338).

Assim, pode-se constatar que a decisão de investir tantos esforços em energia nuclear e não em reconversão da energia solar é uma decisão a favor de alguns temas de pesquisas em virtude de suas aplicações práticas não por razões ligadas a uma concepção particular de natureza epistêmica (Piaget; Garcia, 2011: 338 - 339).

Por outro lado, Piaget e Garcia identificam um outo tipo de ideologia (a ideologia epistêmica) na determinação da aceitação ou rejeição de conceitos ou temas cujo caráter "científico" é negado ou exaltado num determinado momento histórico estritamente por não se adequarem ao ou reproduzirem o aparelho conceitual que a comunidade científica considera como o único válido.

A mecânica de Newton só foi aceita na França após trinta anos. (...) Algumas décadas mais tarde, as explicações “à Newton” eram não só universalmente aceitas, como tinham se tornado o próprio modelo da explicação científica (Piaget; Garcia, 2011: 339).

Desta maneira, evidencia-se a influência deste tipo de paradigma que não se impõe de fora a partir de normas socialmente estabelecidas, mas constitui a maneira natural de aceitação para todo indivíduo que pretenda produzir e ter a sua produção considerada legítima na comunidade dos investigadores científicos num determinado período, sem imposição externa explícita.

É uma concepção que se tornou parte integrante do conhecimento aceito e que com ele se transmite tão naturalmente quanto se transmite a linguagem falada ou escrita de uma geração a outra. É assim que propomos designar esse tipo de paradigma como um "paradigma epistêmico" 
em oposição ao "paradigma social” descrito anteriormente (Piaget; Garcia, 2011: 339).

\section{Pragmática, Teoria Consensual da Verdade e Comunicação}

Com George Mead a Comunicação se liberta da condição menor de mero instrumento para satisfação de interesses particulares do sistema da estrutura de poder a que a Mass Communication Research a diminuiu. A Teoria da Comunicação de Mead reconhece na comunicação o fator distintivo da humanidade diante das demais espécies do reino animal, quando o ser humano, no seu desenvolvimento filogenético, deixou de realizar a sua integração através de gestos e sons para vivenciar uma integração social baseada em símbolos de significado idêntico, ou seja através da intercompreensão comunicativa. Esta concepção se constituiu num passo decisivo para superação da filosofia da consciência no sentido da filosofia da linguagem.

A pragmática é uma corrente filosófica iniciada por Peirce que presta especial atenção à relação entre os signos e os seus utilizadores, compreendendo que, para além das dimensões sintática e semântica na análise do processo sígnico, há uma dimensão contextual, a qual evidencia que o signo não é independente da sua utilização.

A novidade da abordagem pragmatista da semiose está em não remeter a utilização dos signos para uma esfera exclusivamente empírica, sóciopsicológica, mas encarar essa utilização de um ponto de vista lógicoanalítico. A dimensão pragmática é tal como as dimensões sintática e semântica da semiose uma dimensão lógica" (Fidalgo, 1998: 90).

Na perspectiva pragmática, - a validade de uma teoria deve ser medida pela sua adequação para resolução de problemas práticos do mundo da vida, sem se restringir às questões exclusivamente teóricas - "a validade de uma teoria consiste apenas numa adequação à prática. Pragmatismo significa positivamente, neste sentido, a percepção lúcida dos problemas e a capacidade prática de os resolver sem preocupações de ordem teórica" (Fidalgo, 1998: 45).

Mas qual o significado originário que C. S. Peirce atribuiu ao termo 'pragmatismo'? Esse significado pode encontrar-se no artigo de Peirce 'Como tornar as nossa ideias claras' de 1878 . O pragmatismo tal como 
Comunicação, Ideologia e Ciência: questões epistemológicas e

transparece da máxima pragmatista formulada aí por Peirce é sobretudo um método lógico de clarificação das ideias. O significado originário de pragmatismo é de natureza lógica (Fidalgo, 1998: 46).

No desenvolvimento de sua reflexão, Peirce começa por questionar a noção cartesiana de clareza, ponderando que, nesta tradição lógica iniciada por Descartes, clareza significa a capacidade de reconhecer uma ideia em qualquer circunstância que ela ocorra e nunca a confundir com nenhuma outra, o que apresenta dois problemas. O primeiro diz respeito ao fato de que esta capacidade é sobre-humana, uma vez que ninguém pode representar uma ideia que seja reconhecida em todos os contextos e em todas as formas em que ela surgisse, não duvidando nunca de sua identidade, o que seria incorrer numa presunção similar à da teoria positivista da verdade como correspondência, que também implica uma universalidade completa, uma verdade absoluta. $\mathrm{O}$ segundo é que esse reconhecimento não seria mais do que uma "familiaridade com a ideia em causa. Neste caso, porém, teríamos um sentimento subjetivo sem qualquer valor lógico. A clareza de uma ideia não pode resumir-se a uma impressão" (Fidalgo, 1998: 46).

A teoria da verdade e da realidade é formulada por Peirce vinculando as noções de verdade e realidade à crença de uma comunidade de comunicação, onde, nos casos em que estas se mostram mal-sucedidas, a consequente dúvida vai provocar uma inquirição com o objetivo de construir uma nova crença mais evoluída num processo de semiose ilimitada. Esta concepção pioneira da teoria consensual da verdade vai se tornar a engenharia do pensamento moderno, oferecendo as bases de refutação da lógica tradicional.

Segundo Anabela Gradim (2011: 87), quando Peirce afirma ser um realista, tem em mente uma dimensão epistemológica, significando com isso que "o real existe, resiste-nos e não é uma ficção humana". Mas há um aspecto mais sutil na nova teoria da realidade peirceana, que se manifesta quando define o real como aquilo que é cognoscível a longo prazo, ou aquilo no qual a informação e o raciocínio mais cedo ou mais tarde resultarão. O real é real é assim identificado com o cognoscível e com aquilo que é representado pela comunidade na opinião final.

Para Peirce, o objeto da opinião verdadeira constitui então o real e este é exterior à mente, causando no homem a sensação e a experiência. Isso é que põe em marcha o processo de inquiry, que depois alimenta através do 
confronto das hipóteses com o real. Quando se afirma algo do real, essa proposição é verdadeira, não por causa do enunciador, mas sê-lo-á independentemente do que qualquer homem possa pensar dela (Gradim, 2011: 88).

A realidade externa que "corresponde aos nossos sentidos e sensações" é independente do pensamento de qualquer homem particular - mas não do pensamento em geral. Com isso Peirce salva a objetividade da "opinião final" da comunidade, que faz coincidir com o real - tornando a verdade e o real coincidentes com o objeto dessa final opinion. Sendo a realidade o objeto da opinião final, se esta se confinasse a um grupo particular, então as externalidades que lhe correspondessem poderiam muito bem ser concebidas pelo grupo e, em suma, seriam idealistas. Consequência imediata desta visão do real é que este não é causa, mas produto da atividade mental humana e fruto de um processo de comunicação (Gradim, 2011: 90).

Embora se convencione localizar o advento histórico da guinada linguística/pragmática na década de 60 do século XX, é imprescindível para sua adequada compreensão o reconhecimento de que a construção do paradigma científico construtivista já vinha sendo elaborada desde o século XIX, com os pragmáticos George Mead, Charles Peirce, entre outros, que foram marginalizados pela hegemonia da ideologia epistêmica de ciência positivista e sua completa subordinação à ideologia social da época, através da chamada Mass Communication Research norte-americana.

Neste contexto de obscurantismo científico, o positivismo colonizou por várias décadas a reflexão crítica e toda concepção teórica que reconhecesse o estatuto científico da comunicação como a dimensão da humanidade que a distingue das demais espécies do reino animal, bem como o empoderamento da sociedade através da possibilidade da agência humana ressignificar os conteúdos existentes na ordem institucional estabelecida e empreender a mudança social, com a gradativa emancipação dos mecanismos de dominação, repressão e violência simbólica. A grande maquinaria de ideologia epistêmica colocada em ação pelo positivismo estava baseada numa epistemologia primária, fetichizada pela ideia do acesso à verdade absoluta das leis de causa e efeito universais, e por uma metodologia restrita à rotina fática de uma pesquisa burocratizada realizada exclusivamente através dos procedimentos de mensuração das técnicas quantitativas. 


\section{Considerações Finais: A Comunicação como Ciência Qualitativa na cons- trução social da realidade}

Fechando o parêntese sobre ideologia, é mister, por fim se pensar que a Comunicação enquanto uma ciência, ambas sofrendo influências de seus caracteres opacos, não pode ser estudada apenas nos moldes quantitativos, com a finalidade de aferição e averiguação racional como pretendeu as pesquisas positivitas. A Comunicação precisa ser também tensionada como uma ciência essencialmente qualitativa e que, embora tenha sofrido severos preconceitos ao longo da história, tem sido recolocada como fator determinante nas investigações mais atuais das Ciências Sociais Aplicadas.

Ao fazer referência a um estudo qualitativo, estar-se levando em consideração o que Bauer, Gaskell e Allum (2002: 23) reconstruíram metodologicamente: "pesquisa qualitativa evita números, lida com interpretações das realidades sociais, e é considerada pesquisa soft".

Em virtude da forte predominância dos moldes positivistas de se conceber a ciência, legando às pesquisas quantitativas, por muitos anos, o topo da legitimidade racional-científica, a pesquisa qualitativa foi marginalizada e considerada apenas no estágio exploratório do processo de pesquisa, com a finalidade de explorar distinções qualitativas, a fim de se desenvolver mensurações, ou para que se tivesse certa sensibilidade com o campo de pesquisa. Entretanto, formulações mais recentes consideram a pesquisa qualitativa como igualmente importante para guiar, inclusive, a análise dos dados levantados ou mesmo para fundamentar interpretações. Agora a pesquisa qualitativa é vista como um empreendimento autônomo de pesquisa, no contexto de um programa de pesquisa com uma série de diferentes projetos (Bauer, Gaskell e Allum: 2002).

Dessa forma, mesmo uma pesquisa quantitativa não chega às suas conclusões objetiva e automaticamente, mas carece imprescindivelmente de ações qualitativas até para a escolha / exclusão de categorias, de delimitação de objetos, de procedimentos metodológicos de coletas dados, como de ações interpretativas para análise dos dados obtidos.

Segundo Bauer, Gaskell e Allum (2002):

A mensuração dos fatos sociais depende da categorização do mundo social. As atividades sociais devem ser distinguidas antes que qualquer frequência ou percentual possa ser atribuído a qualquer distinção. 
É necessário ter uma noção das distinções qualitativas entre categorias sociais, antes que se possa medir quantas pessoas pertencem a uma ou outra categoria. Se alguém quer saber a distribuição de cores num Jardim de flores, deve primeiramente identificar o conjunto de cores que existem no jardim; somente depois disso pode-se começar a contar as flores de determinada cor. O mesmo é verdade para os fatos sociais (Bauer, Gaskell e Allum, 2002: 24).

Confirmando isso, Isaac Epstein (2005: 27) afirma que todo e qualquer "procedimento quantitativo deve ser precedido por uma reflexão sobre quais os atributos pelos quais os fenômenos estudados são dessemelhantes e podem ser ignorados em relação aos objetivos pretendidos".

Destarte, quantos aos objetivos da pesquisa, Gaskell (2002) aclara:

A finalidade real da pesquisa qualitativa não é contar opiniões ou pessoas, mas, ao contrário, explorar o espectro de opiniões, as diferentes representações sobre o assunto em questão. Em um meio social específico, digamos, na profissão médica, o que nós estamos interessados em descobrir é a variedade de pontos de vista no assunto em questão, por exemplo, a homeopatia, e especificamente o que fundamenta e justifica estes diferentes pontos de vista (Gaskell, 2002: 68).

Gaskell (2002) anota que o principal objetivo da pesquisa qualitativa é apresentar uma amostra do espectro dos pontos de vista, pensados em termos sociais. Seguindo essa linda de pensamento, Bauer, Gaskell e Allum (2002) abordam o mundo, como o conhecemos e o experienciamos, isto é, o mundo representado e não o mundo em si mesmo, como algo constituído através de processos de comunicação, corroborando assim com Berger \& Luckmann. A pesquisa social qualitativa, portanto, apoiar-se-ia em dados sociais, dados sabre o mundo social, que são o resultado, e são construídos nos processos de comunicação.

Para tanto, os autores (2002) distinguem dois tipos de dados sociais - os que são construídos através de uma comunicação informal (existente na vida cotidiana, em que as pessoas espontaneamente se expressam e falam sobre o que é importante para elas e como elas pensam sobre suas ações e as dos outros) e os que são resultados da comunicação formal (que exige conhecimento especializado para seguir as regras do mercado, como o treino para escrever 
Comunicação, Ideologia e Ciência: questões epistemológicas e metodológicas

artigos de jornal, para produzir desenhos para um comercial, ou para criar um arranjo para uma banda popular ou para uma orquestra sinfônica).

Em se tratando dessa comunicação formal sob o viés construtivista, Bauer, Gaskell e Allum (2002) elucidam:

Os dados formais reconstroem as maneiras pelas quais a realidade social é representada por um grupo social. Um jornal representa até certo ponto o mundo para um grupo de pessoas, caso contrário elas não o comprariam. Nesse contexto, o jornal se torna um indicador desta visão de mundo. O mesmo pode ser verdade para desenhos que as pessoas consideram interessantes e desejáveis, ou para uma música que é apreciada como agradável. O que uma pessoa lê, olha, ou escuta, coloca esta pessoa em determinada categoria, e pode indicar o que a pessoa pode fazer no futuro (Bauer, Gaskell e Allum, 2002: 22).

Assim, pensar a Comunicação e a Ciência como elementos importantes na construção social da realidade é também analisar seus caracteres opacos, presentes inclusive na linguagem. Esse caráter opaco, estudado enquanto ideologia, pode sim atuar e operar na tentativa de estabelecer e manter relações de dominação, mas, como analisou Castro \& Rocha (2014), Eagleton (1997) e Habermas (1997), em dadas circunstâncias de crises e tomadas de consciência, pode ser uma ferramenta também de estabelecimento de uma oposição, de autonomia em relação à dominação estabelecida e algumas vezes até de reordenação das forças.

Neste sentido, como vislumbra Boaventura de Souza Santos (2001: 57), a ciência, que surgiu e se afirmou na modernidade se distinguindo do senso comum e o menosprezando, precisa agora assumir o desafio educativo, no qual também não pode prescindir da comunicação, de elevar o nível de consciência e conhecimento das massas a tal ponto de vir a se tornar senso comum.

\section{Referências Bibiográficas}

Bauer, M.W.; Gaskell, G. \& Allum, N.C. (2002). Qualidade, quantidade e interesses do conhecimento - Evitando confusões. In M.W. Bauer \& G. Gaskell (Orgs). Pesquisa qualitativa com texto: imagem e som: um manual prático. Tradução de Pedrinho A. Guareschi. Petrópolis: Vozes. 
Berger, P. \& Luckmann, T. (2003). A construção social da realidade: tratado de sociologia do conhecimento. Petrópolis: Vozes.

Castro, R. \& Rocha, H.C.L. (2014). Junho de 2013 no Brasil: O jornalismo e a ideologia. In H. Rocha, R. Castro \& A. Vizeu, Comunicação e Ideologia. Recife: PROEXT-UFPE \& Ed. Universitária da UFPE.

Correia, J.C. (2004). A Teoria da Comunicação de Alfred Schutz. Lisboa: Livros Horizonte, Colecção: Media e Jornalismo.

Corcuff, P. (2001). As novas sociologias: construções da realidade social. Rio de Mouro, Sintra.

Dijk, T.A. (2012). Discurso e poder. São Paulo: Contexto.

Durante, R.D.A. (2013). A comunicação como um jogo: sobre a dimensão lúdica como a política da diversão programada em Vilém Flusser. São Paulo: PUC. Tese de doutorado apresentada ao Programa de PósGraduação em Comunicação e Semiótica, da Pontifícia Universidade Católica de São Paulo. Disponível em: www.sapientia.pucsp.br. Acesso em: out 2014.

Eagleton, T. (1997). Ideologia: uma introdução. São Paulo: Editora da Universidade estadual Paulista.

Epstein, I. (2005). Ciência, poder e comunicação. In J. Duarte \& A. Barros (Orgs). Métodos e técnicas de pesquisa em comunicação. São Paulo: Atlas.

Fidalgo, A. (1998). Semiótica: a lógica da comunicação. Covilhã: Serviços Gráficos da Universidade da Beira Interior.

Gaskell, G. (2002). Entrevistas individuais e grupais. In M.W. Bauer \& G. Gaskell (Orgs). Pesquisa qualitativa com texto: imagem e som: um manual prático. Tradução de Pedrinho A. Guareschi. Petrópolis: Vozes.

Gradim, A. (2011). My language is the sum total of myself: universos dialógicos em Peirce. In J.M. Santos, P.M.S. Alves \& J.P. Serra, (Orgs.). Filosofias da Comunicação. Portugal, Covilhã: Editora da Universidade da Beira Interior, Livros Labcom, Série Estudos em Comunicação.

Habermas, J. (2002). A inclusão do outro: estudos de teoria política. São Paulo: Loyola. 
Comunicação, Ideologia e Ciência: questões epistemológicas e metodológicas

Habermas, J. (1997). Direito e Democracia: entre facticidade e validade. Vol II. Rio de Janeiro: Tempo Brasileiro.

Habermas, J. (1968). Técnica e Ciência como Ideologia. Lisboa: Edições 70.

Marcondes, D. (2000a). Desfazendo mitos sobre a pragmática. ALCEU, 1(1): 38-46, jul/dez. Disponível em: www.ifcs.ufrj.br. Acesso em: 28 jan 2014.

Marcondes, D. (2000b). Filosofia, linguagem e comunicação. São Paulo: Cortez Editora.

Marx, K. (1997). O 18 Brumário e cartas a Kugelmann. Rio de Janeiro: Paz e Terra.

Marx, K. \& Engels, F. (2004). A ideologia Alemã. São Paulo: Martin Claret.

Piaget, J. \& Garcia, R. (2011). Psicogênese e história das ciências. Petrópolis: Vozes.

Ricoeur, P. (1996). Interpretação e Ideologias. $4^{\mathrm{a}}$ Ed. Organização e Tradução de Hilton Japiassu. Rio de Janeiro: Francisco Alves.

Rüdiger, F. (2009). Ciência social crítica e pesquisa em comunicação: trajetória histórica e elementos de epistemologia. Porto Alegre: Gattopardo.

Serra, J.P. (2003). Informação e Sentido: o estatuto epistemológico da informação. Covilhã/Portugal: Editora da Universidade da Beira Interior, Livros Labcom.

Santos, B.S. (2001). Um discurso sobre as ciências. Porto: Edições Afrontamento, $12^{\mathrm{a}}$ edição.

Schütz, A. (2003). El Problema da realidad social. Buenos Aires: Amorrortu.

Thompson, J.B. (1995). Ideologia e cultura moderna: teoria social crítica na era dos meios de comunicação de massa. Petrópolis: Vozes, 1995.

Wittgenstein, L. (2000). Investigações filosóficas. São Paulo: Ed. Nova Cultural (Col. Os Pensadores - trad.: José Carlos Bruni). 
$\bigoplus$

$\bigoplus$

$\oplus$ 


\title{
La espiral del conocimiento en la redacción de artículos científicos
}

\author{
María del Rosario Demuner-Flores, Rosa María Nava Rogel \& \\ Patricia Mercado-Salgado \\ Universidad Autónoma del Estado de México \\ E-mail: demuner7@yahoo.com/pat_mersal@yahoo.com
}

\begin{abstract}
Resumen
El último reto de toda investigación es comunicar los hallazgos encontrados de manera efectiva. Sin embargo, en las áreas económico administrativas, muchas veces no se comunica lo encontrado, ya sea porque lo encontrado no tiene una base teórica sustentable, porque no hay congruencia entre el título, el objetivo del trabajo y las conclusiones, porque los resultados encontrados no respaldan las conclusiones, porque no se explica

conocimiento o porque no se comunica una sola idea de manera sencilla e impactante. Este trabajo propone un método de gestión del conocimiento basados en la espiral del conocimiento (Nonaka y Takeuchi, 1995) que ayude a la elaboración de artículos científicos, a partir del análisis de las deficiencias encontradas en algunas investigaciones enviadas a una Revista de Administración de una universidad mexicana de alcance internacional.
\end{abstract} la aportación que hace el documento al

Palavras-clave: Conocimiento; artículos científicos; revistas científicas; divulgación.

\begin{abstract}
The last challenge of any investigation is to communicate the findings effectively. However, the administrative economic areas, often does not communicate the findings, either because it found no sustainable theoretical basis, no congruence between the title, the aim of the work and findings, the results do not support the conclusions, the contribution to

one idea so simple and powerful does not communicate. This paper proposes a method of knowledge management based on knowledge spiral (Nonaka and Takeuchi, 1995) to assist in the preparation of scientific papers, from the analysis of the deficiencies found in some research sent to Mexican Journal of Management of international scope.
\end{abstract} knowledge is not explained or because 
Keywords: Knowledge; scientific articles; scientific journals; disclosure.

\section{Introducción}

T A divulgación de la ciencia mediante la publicación de artículos científiL cos en revistas indexadas es una necesidad de cada investigador. Aunque existe una gran aportación tendiente a enseñar a escribir este tipo de documentos, se advierten rechazos de los mismos cuando éstos participan en un proceso de revisión por pares académicos, como el comúnmente usado en las revistas especializadas e indexadas. El peer review, es una actividad que toda revista científica emplea para su proceso editorial, su objetivo es precisamente, avalar la calidad de la investigación presentada para su posible publicación.

Los autores esperan un veredicto de aceptación, sin embargo, si éste implica un rechazo en una revista con una alta tasa de aceptación, donde existe mucha competencia y donde los árbitros argumentan su decisión exponiendo ideas de mejora, estas causas de rechazo se convierten en oportunidades que el autor considera para fortalecer su artículo. Cuando el árbitro condiciona el artículo es porque el autor tiene la oportunidad de considerar las observaciones que se le hicieron, y si contesta adecuadamente, quiere decir que su artículo está entre aquellos no aceptados inicialmente y su probabilidad de aceptación es del 50\%, la decisión final dependerá enteramente de la calidad de los cambios realizados y las respuestas ofrecidas a las cuestiones planteadas (Bermejo, 2002)

La calidad en los artículos, muchas veces es cuestionada porque lo que se comunica no tiene una base teórica sustentable, o se advierten incongruencias entre el título, el objetivo, las preguntas de investigación y las hipótesis; por otra parte, los resultados encontrados no respaldan las conclusiones. Adicionalmente la calidad se demerita debido al mal uso de la ortografía y la gramática.

Muchos de los estudios empíricos que se han centrado en los contextos de investigación y desarrollo similares, han tendido a utilizar diferentes medidas, con poca preocupación para la triangulación con estudios previos (Lane, Koka y Pathak, 2006). Esto ha dado lugar a un patrón disperso de la acumulación del conocimiento en el que los estudios son estadísticamente significativos, 
pero teóricamente fragmentados (Tsang y Kwan, 1999), un problema común en la mayoría de las áreas de investigación de la organización (Lane, Koka y Pathak, 2006).

Entre las principales causas de rechazo de un artículo se encuentran: falta de una hipótesis clara, ambición excesiva y falta de foco, exposición de un problema nuevo de poca importancia, falta de preparación o investigación antes de someter el manuscrito a su revisión para publicación, mal diseño del caso de aplicación, aplicabilidad sobre generalizada de los hallazgos y mala escritura (Fisher y Powers 2004).

Por su parte Lane, Koka, Pathak (2006:859) mencionan algunos aspectos que hacen que se demerite la calidad de las publicaciones:

- Las presiones para publicar han creado un desincentivo para que los investigadores puedan invertir el tiempo necesario para desarrollar una comprensión mas profunda de cualquier constructo.

- La reticencia de las revistas científicas en ciencias sociales a publicar estudios de réplica han logrado desincentivar aún mas.

- Las presiones de saltar de investigaciones emergentes para publicar rápidamente y evitar réplicas.

Aunque existe abundante literatura sobre cómo hacer un artículo científico, metodologías para realizar la investigación y normas editoriales que cada revista establece para aceptar artículos, esto no basta, el investigador debe encontrar su propio estilo para organizar y plasmar sus ideas. Es decir, debe adoptar un método adecuado a sus propias habilidades. Grawitz (1974) plantea que un método puede entenderse en cuatro formas: 1) sentido filosófico, siendo éste el nivel más alto de abstracción donde el método denota los procedimientos lógicos que debe seguir el investigador para acercarse a la verdad y verificarla; 2) el método también se refiere a la actitud que adopta el investigador respecto al objeto de estudio, por lo que en este nivel el método orienta la forma en que se organiza y lleva a cabo la investigación; 3) el sentido que adquiere el método es por su vinculación con un intento de explicación, por lo que la posición filosófica seleccionada por el investigador influye en el método a seguir en la investigación; y 4) un método propio acorde con el campo de conocimiento del investigador.

En este sentido, el presente trabajo tiene como objetivo aportar un método aplicado a trabajos de las disciplinas económico administrativas con el fin de socializar, externalizar, combinar e internalizar el conocimiento. Para ello, el 
trabajo presenta en primer lugar, un marco teórico que describe el modelo de la espiral del conocimiento; en segundo lugar se muestra cómo se desarrolló el estudio descriptivo, para finalmente presentar la propuesta seguida de algunas reflexiones finales.

\section{Fundamento Teórico}

Nonaka y Takeuchi (1995) explican el papel protagónico de la empresa para generar las condiciones que permiten la creación, difusión y aplicación del conocimiento a partir de la intención, autonomía, fluctuación y caos creativo, redundancia y variedad de requisitos. A través del modelo que proponen: "la espiral del conocimiento", se enfatiza y ubica el desarrollo del conocimiento en cuatro etapas.

El modelo inicia en la socialización del conocimiento con la creación de un campo de interacción que permite que los investigadores compartan sus experiencias y modelos mentales. En segundo lugar, la externalización se da a partir de un diálogo o reflexiones colectivas significativas, en los que el uso de una metáfora o una analogía apropiadas ayudan a los investigadores a enunciar el conocimiento tácito oculto, que de otra manera resulta difícil de comunicar. En tercer lugar, la combinación da comienzo con la distribución por redes del conocimiento recién creado y el conocimiento existente de otras fuentes, cristalizándolos así en un nuevo producto. Y en cuarto lugar, la internalización se origina en aprender haciendo. Pero el conocimiento no termina en la cuarta etapa, en ella surgen nuevas inquietudes, perspectivas, avances, dominios que hacen que el proceso se re inicie con la socialización del conocimiento.

Para que los investigadores capten, compartan, organicen y utilicen los conocimientos para lograr un trabajo de investigación que cuente con los requisitos que exigen las revistas científicas, deben implementar un procedimiento propio, que incorpore el desarrollo de una aministración activa y consciente de crear, diseminar, evolucionar y aplicar el conocimiento a fines estratégicos (Bedrow y Lane, 2003).

Si bien existe vasta literatura que aporta modelos para gestionar el conocimiento, para este estudio usaremos el modelo "La espiral de conocimiento" aportado por Nonaka y Takeuchi (1995) que identifica cuatro tipos de conocimiento: 
1. El conocimiento tácito es un conocimiento personal que está enraizado en la acción individual y en la experiencia, así como en los ideales, valores o emociones que el individuo adopta (Nonaka y Takeuchi, 1995).

2. El conocimiento explícito es el fruto de un proceso de aprendizaje; su manifestación se da a través de un lenguaje formal y sistemático que puede ser escrito, auditivo o visual, y se recopila y comparte mediante datos, fórmulas, especificaciones y manuales (Byosiere, 1999). Este tipo de conocimiento es apropiable y transmisible, a su vez está abierto a la participación y colaboración de los individuos ya que se encuentra materializado en soportes de fácil acceso, salvo que esté protegido mediante patentes (Osterloh y Frey, 2000).

3. El conocimiento individual se genera en la persona misma y puede ser el sustento del conocimiento colectivo.

4. El conocimiento colectivo es compartido por los miembros de la comunidad, y por tanto no depende de ningún individuo en concreto.

\section{Metodología}

Toda investigación tiene la responsabilidad y el compromiso de ser difundida, de comunicar los hallazgos encontrados de manera efectiva de tal forma que ayude a la generación de conocimiento y/o a la solución de problemas de la sociedad. Con el fin de aportar ideas de mejora en la elaboración de artículos científicos y disminuir el índice de rechazo, se desarrolla un estudio descriptivo que explica la experiencia que ha tenido una revista científica con los artículos que ha recibido para su publicación, desde su creación hasta la última publicación.

La unidad de análisis está representada por los artículos que ha recibido la revista desde su reciente creación (2012) a la última publicación de 2014. Se trata de una revista electrónica cuyo objetivo es crear un espacio que impulse, genere y promueva actividades de investigación y reflexión en el área académico administrativa. Cuenta con ISSN y es reconocida por cuatro índices: Dialnet, Latindex, CLASE y BASE Biblioteca de la Universidad de Bielefeld. En su página Web presenta las normas editoriales, así como los números publicados. 


\section{Resultados}

La revista publicó 8 números hasta 2014, recibió en total 80 artículos de los cuales el $26 \%$ fueron rechazados desde la revisión de escritorio, ya sea porque el contenido no correspondía a la temática que maneja la revista, por la poca relevancia del tema, por el incumplimiento en la forma, aunado a alguna otra debilidad como el tratamiento metodológico, la revisión teórica, antigüedad en las fuentes consultadas, presentación y discusión desordenada de los resultados, entre otras.

Respecto a los artículos rechazados por los árbitros, la tasa es de $18 \%$ que al sumarse con los rechazados por el editor, en su revisión de escritorio, la tasa de rechazo de la revista alcanza el $44 \%$.

En total fueron enviados a revisión peer view 59 artículos, de los cuáles 49 fueron aceptados, siendo la tasa de aceptación el 83\%, cabe hacer mención que algunos de estos artículos fueron condicionados a algunas pequeñas modificaciones, pero que al re enviarlos en la segunda ronda a los árbitros, ellos dieron el voto de aceptación (Ver tabla 1).

Como puede observarse el índice de rechazo es del 17\%. Las causas de rechazo de parte de los pares académicos que se identificaron, versan en los siguientes términos:

1. Falta de congruencia entre el título, el objetivo del trabajo y las conclusiones.

2. Escaza revisión teórica

3. Los resultados encontrados no respaldan las conclusiones

4. Metodología débil

5. Falta de argumentación

6. Poca o nula originalidad

7. Inadecuado tratamiento de los datos 
Tabla 1. Artículos recibidos, aceptados y rechazados

\begin{tabular}{lccccc} 
& 2014 & 2013 & 2012 & Total & \\
\hline Números publicados & 3 & 3 & 2 & 8 & 15 \\
Envíos totales & 37 & 25 & 18 & 80 & $100 \%$ \\
Rechazados por incumplir normas editoriales & 13 & 5 & 3 & 21 & $26 \%$ \\
Revisión por pares & 24 & 20 & 15 & 59 & $100 \%$ \\
Aceptados & 20 & 16 & 13 & 49 & $83 \%$ \\
Rechazados por pares & 4 & 4 & 2 & 10 & $17 \%$ \\
\hline
\end{tabular}

Fuente: elaboración propia.

\section{Método propuesto para gestionar el conocimiento en investigación}

Con el fin de mostrar un método que ayude al investigador a organizar y estructurar su conocimiento, se propone adoptar el aquí sugerido, mismo que se retoma de Demuner, Nava y Sandoval (2015) y cuyo sustento teórico es el modelo de la Espiral del conocimiento de Nonaka y Takeuchi (1995).

El conocimiento se crea cuando se produce una transformación del saber tácito del investigador en explícito a nivel grupal y organizativo; cada uno de los miembros de tales colectivos lo interiorizan, convirtiéndolo de nuevo en tácito (Nonaka y Takeuchi, 1995).

La espiral del conocimiento enfatiza y ubica el desarrollo del conocimiento en cuatro etapas. Inicia en la socialización del conocimiento con la creación de un campo de interacción que permite que los miembros del equipo compartan sus experiencias y modelos mentales. En segundo lugar, la externalización se da a partir de un diálogo o reflexiones colectivas significativas, en los que el uso de una metáfora o una analogía apropiadas ayudan a los miembros a enunciar el conocimiento tácito oculto, que de otra manera resulta difícil de comunicar. En tercer lugar, la combinación da comienzo con la distribución por redes del conocimiento recién creado y el conocimiento existente de otras secciones de la organización, cristalizándolos así en un nuevo producto, servicio o sistema administrativo. Y en cuarto lugar, la internalización se origina en aprender haciendo. Pero el conocimiento no termina en la cuarta etapa, en ella surgen nuevas inquietudes, perspectivas, avances, dominios que hacen que el proceso se re inicie con la socialización del conocimiento. 


\section{Socialización}

Consiste en pasar de un conocimiento tácito a otro conocimiento tácito. Se da cuando un investigador adquiere conocimiento ya sea por algún tipo de comunicación, por simple observación, imitación o práctica. Es un proceso en el que el investigador adquiere conocimiento tácito al leer, estudiar, compartir experiencias y pensamientos con otros investigadores o con algún grupo de interés, de manera que incrementa su saber y llega a conseguir niveles cercanos a los del emisor.

Para conseguir tales resultados se realizan dos actividades clave claramente diferenciadas (Nonaka y Konno, 1998), la primera, captar conocimiento a través de la interrelación con investigadores externos, grupos o centros de investigación, e internos que son colegas de la misma organización, línea de investigación o disciplina, procedente de la proximidad física o de la interacción virtual; y la segunda, diseminar el conocimiento, es decir, transferirlo a otro individuo como una exposición del tema en un salón de clases, un congreso o alguna reunión formal. En este proceso el investigador puede adquirir conocimiento tácito directamente de otros sin necesariamente usar el lenguaje (Ver tabla 2).

Medios que se pueden emplear para socializar el conocimiento:

a) Desarrollo de espacios para compartir experiencias y habilidades

b) La observación, la imitación y la práctica.

c) Exposiciones orales, discusiones detalladas, como un mecanismo con el cual los individuos buscan la armonía al involucrarse tanto en experiencias corporales como mentales.

d) Aprendizaje en equipo. La interacción con colegas antes del desarrollo del producto de investigación y después de haberlo publicado, es un proceso inter $\neg$ minable de intercambio de experiencias, habilidades y de creación de ideas para mejorar. 
Tabla 2.Proceso de socialización

\begin{tabular}{ll} 
Actividad & Descripción \\
\hline $\begin{array}{l}\text { Reconocer al otro como per- } \\
\text { sona }\end{array}$ & $\begin{array}{l}\text { Se utiliza para construir un campo de interacción, reco- } \\
\text { nociendo las distintas características de los individuos } \\
\text { como antecedentes, experiencia profesional dentro y fu- } \\
\text { era de la organización, metas individuales, perspectivas } \\
\text { y motivaciones. }\end{array}$ \\
$\begin{array}{l}\text { Conocimiento del otro para } \\
\text { generar confianza mutua }\end{array}$ & $\begin{array}{l}\text { Se trata de construir un entorno empático y de mutua } \\
\text { confianza, por lo que las emociones, sentimientos y cre- } \\
\text { encias de cada persona tendrían que ser compartidos. }\end{array}$ \\
Interactuación cara a cara & $\begin{array}{l}\text { Los investigadores involucrados deben interactuar por } \\
\text { cierto tiempo, cara a cara, como un equipo auto dirigido } \\
\text { con una meta específica que deben cumplir. } \\
\text { Se da casi de manera imperceptible, pues a partir de }\end{array}$ \\
Transferencia & $\begin{array}{l}\text { la interacción y la interactuación, las personas pueden } \\
\text { generar y transmitir conocimiento tácito. }\end{array}$ \\
Sólo se podrá hacer en aquellos investigadores que se \\
involucraron en el proceso.
\end{tabular}

Fuente: adaptado de Demuner, Nava y Sandoval (2015).

\section{Externalización}

Transita de un conocimiento tácito a un conocimiento explícito. El conocimiento que poseen los investigadores a título personal se traduce en conceptos que integran un conocimiento colectivo. Es la etapa clave de creación de conocimiento; es ella en la que el conocimiento tácito se convierte en conceptos explícitos o comprensibles. Este proceso se realiza en dos fases, en la primera, mediante metáforas se reconocen contradicciones, y en la segunda por medio de analogías, se da solución a las mismas. La externalización se observa típicamente en el proceso de creación de conceptos y es generada por el diálogo o la reflexión colectiva, a través de la propia articulación de éste (Nonaka y Konno, 1998) (Ver tabla 3).

Medios que se pueden emplear para exteriorizar el conocimiento:

a) Utilización de metáfora

b) Uso de analogías

c) Uso de teoremas, hipótesis

d) Modelo 
e) Eslogan

Tabla 3.Proceso de externalización

\begin{tabular}{|c|c|}
\hline Actividad & Descripción \\
\hline Interacción & $\begin{array}{l}\text { Se inicia con un campo de interacción, en el que se ma- } \\
\text { nifiesta un modelo mental (conocimiento tácito) que se } \\
\text { compartirá con otros individuos. }\end{array}$ \\
\hline Reflexión colectiva & $\begin{array}{l}\text { Los involucrados en el proceso mantienen un diálogo } \\
\text { continuo y constante, desarrollando reflexiones colecti- } \\
\text { vas sobre recursos, actividades y mejores prácticas. }\end{array}$ \\
\hline Creación de conceptos & $\begin{array}{l}\text { Se construye paulatinamente y como resultado de cons- } \\
\text { tantes reflexiones colectivas, pues a partir de la interac- } \\
\text { ción y la interactuación el modelo mental tácito que se } \\
\text { ha compartido con otros, se verbaliza en palabras y fra- } \\
\text { ses para aterrizarlo en conceptos explícitos (diagramas, } \\
\text { analogías, esquemas, etc.) }\end{array}$ \\
\hline Validación de conceptos & $\begin{array}{l}\text { Se determina si los conceptos creados son válidos para } \\
\text { todos los casos y productos/servicios solicitados en la } \\
\text { organización. }\end{array}$ \\
\hline Distribución & $\begin{array}{l}\text { Se hace con personas dentro y/o fuera de la organiza- } \\
\text { ción, a partir de una capacitación sobre el lenguaje uti- } \\
\text { lizado. }\end{array}$ \\
\hline
\end{tabular}

Fuente: adaptado de Demuner, Nava y Sandoval (2015).

\section{Combinación}

Es la parte del proceso que sintetiza los conceptos explícitos y los traslada a una base de conocimiento, mediante la captura e integración de nuevo conocimiento explícito esencial, a través de la recopilación, reflexión y síntesis.

Involucra dos actividades esenciales, la primera, es el procesamiento de documentos, estadísticas, informes, minutas, manuales, etc., y la segunda, tiene que ver con la difusión del conocimiento mediante los procesos de transferencia utilizados normalmente por el investigador (Ver tabla 4).

Medios que se pueden emplear para combinar conocimiento:

a) Documentos (Artículos de investigación, libros, resúmenes investigativos, informes técnicos)

b) Congresos, simposios, conferencias 
c) Conversaciones con grupos de investigación, colegas (Vía Internet, teléfono, videoconferencias, etc.)

d) Redes computarizadas de comunicación

Tabla 4. Proceso de combinación

\begin{tabular}{ll} 
Actividad & Descripción \\
\hline Ordenar & $\begin{array}{l}\text { Agrupar por categorías el conocimiento previamente dialogado y refle- } \\
\text { xionado. }\end{array}$ \\
Clasificar & $\begin{array}{l}\text { Contextualizar el conocimiento ya sea por funciones, áreas, disciplinas, } \\
\text { teorías, modelos, etapas del proceso, actividades de la cadena de valor, } \\
\text { de acuerdo al uso que se le valla a dar. } \\
\text { De acuerdo a como fue clasificado, se decidirá cómo documentar el } \\
\text { conocimiento, ya sea con modelos, diagramas, mapas, procedimientos, } \\
\text { manuales, fichas técnicas, folletos, etc. }\end{array}$ \\
Retroalimentar & $\begin{array}{l}\text { Someter a revisión la documentación elaborada para corregir posibles } \\
\text { errores. }\end{array}$ \\
\hline
\end{tabular}

Fuente: adaptado de Demuner, Nava y Sandoval (2015).

\section{Internalización}

De explícito a tácito. Es la etapa del proceso en la que se amplía el conocimiento tácito del investigador a partir del conocimiento explícito de la organización, al depurarse este último y convertirse en conocimiento propio de cada persona.

La internalización requiere por un lado la actualización de los conceptos o métodos explícitos y, por otro, la inclusión de dicho conocimiento explícito en tácito. La condición necesaria es que el conocimiento explícito sea vivido o experimentado, bien, pasando personalmente por la experiencia de realizar una actividad, o bien a través de la participación, de las simulaciones, o de los ejercicios de juego de rol, para que así el individuo lo haga propio según su particular estilo y hábitos. Para que el conocimiento explícito se vuelva tácito, es de gran ayuda que el conocimiento se verbalice o diagrame en documentos, manuales o historias orales (Ver tabla 5).

Medios que se pueden emplear para internalizar el conocimiento:

a) La documentación ayuda a apropiarse lo que han experimentado, enriqueciendo su conocimiento tácito. 
b) Los manuales facilitan la transferencia de conocimiento explícito a otras personas, permitiendo que experimenten indirectamente las vivencias de otros, es decir, que las re experimenten (por ejemplo, documentar posiciones a favor o en contra de la línea o tema de investigación puede ser utilizada por los miembros del mismo grupo de investigación).

c) Se llevan a cabo modelos mentales compartidos.

d) Las experiencias y procedimientos aplicados se conservan en memorias documentales u otros medios.

e) Uso de otros métodos propios.

Tabla 5. Proceso de internalización

\begin{tabular}{ll} 
Etapa & Descripción \\
\hline Introducción & $\begin{array}{l}\text { Se "presenta" el conocimiento proveniente de una investigación a un } \\
\text { nuevo receptor de la información }\end{array}$ \\
Interpretación & $\begin{array}{l}\text { El nuevo receptor del conocimiento lo interpreta adaptándolo a sus } \\
\text { ideas, modelos o esquemas antecedentes y lo re interpreta. }\end{array}$ \\
Comprensión & $\begin{array}{l}\text { Al poner en "práctica" el conocimiento interpretado, amplía su com- } \\
\text { prensión, buscando mayor cantidad de información u otros conocimi- }\end{array}$ \\
& $\begin{array}{l}\text { entos complementarios que permitan extender su idea } \\
\text { Explicación }\end{array}$ \\
& $\begin{array}{l}\text { Al poder "explicar" al otro, a través de metáforas, nuevas ideas, es- } \\
\text { conocimiento, haciéndolo suyo y por tanto lo ha internalizado }\end{array}$ \\
\hline
\end{tabular}

Fuente: adaptado de Demuner, Nava y Sandoval (2015).

\section{Reflexiones Finales}

Difundir el conocimiento es responsabilidad de todo invstigador. Para crear, identificar, coleccionar, adaptar, aplicar, organizar y finalmente compartir una serie de conocimientos tácitos y explícitos que pueden permitir el mejor desarrollo (Del Moral et al., 2007) de un documento de investigación se propone socializar el conocimiento con la creación de un campo de interacción que permite que un equipo de colegas compartan sus experiencias y modelos mentales.

En segundo lugar, la externalización se da a partir de un diálogo o reflexiones colectivas significativas, en los que el uso de una metáfora o una analogía apropiadas ayudan al investigador a enunciar el conocimiento tácito oculto, que de otra manera resulta difícil de comunicar. 
En tercer lugar, la combinación da comienzo con la distribución por redes del conocimiento recién creado y el conocimiento existente en el grupo, cristalizándolos así en un nuevo producto de investigación, en esta etapa se formaliza lo investigado.

$\mathrm{Y}$ en cuarto lugar, la internalización se origina en aprender haciendo, se da a conocer, se difunde el conocimiento, pero éste no termina en la cuarta etapa, en ella surgen nuevas inquietudes, perspectivas, avances, dominios que hacen que el proceso se re inicie con la socialización del conocimiento.

La creciente presión por publicar e incrementar el número de citas de investigación interdisciplinaria, ha hecho que los estudios sean estadísticamente significativos, pero teóricamente fragmentados (Tsang y Kwan, 1999), un problema común en la mayoría de las áreas de investigación de la organización (Lane, Koka y Pathak, 2006).

En este sentido, el uso del método descrito anteriormente debe verse como un aliciente para el investigador, de tal forma que le motive a realizar aportaciones de calidad. Y aunque existe la presión por la publicación que exigen organismos que fomentan y respaldan la investigación, el objetivo no es lograr una cantidad, sino calidad en las aportaciones que tanto hacen falta a la ciencia básica y aplicada, sobre todo a las ciencias sociales.

\section{Referencias}

Bedrow, H.W.L. (2003). International Joint Ventures: Creating Value through Successful Knowledge. Management, Journal of World Business, 38(1): 15-30.

Byosiere, P. (1999). Fusión y difusión de las esferas de conocimiento en el ámbito regional, Las sociedades del conocimiento (pp. 81-86), editado por Cluster del Conocimiento, Zamudio.

Del Moral, A.; Pazos, J.; Rodríguez, E.; Rodríguez-Patón, A. \& Suárez, S. (2007). Gestión del Conocimiento (pp. 499). Madrid, España: Thomson.

Demuner, F.M.R.; Nava, R.R.M. \& Sandoval, A.R. (2015). TI en la dinàmica del conocimiento empresarial. México: Bonobos Editores.

Fisher, R.S. \& Powers, L.E. (2004). Peer-Review. Publication: a view from inside. Epilepsia, 45(8): 889-894.

Grawitz, M. (1974). Méthodes des sciences socials. Paris: Dalbor. 
Lane, P.J.; koka, B.R. \& Pathak, S. (2006). The reification of absorptive capacity: a critical review and rejuvenation of the construct. Academy of Management Review, 31(4): 833-863.

Nonaka, I. \& Takeuchi, H. (1995). The Knowledge-Creating Company. How Japanese companies create the dynamics of innovations. New York, NY: Oxford University Press.

Nonaka, I. \& Konno, N. (1998). The Concept of "Ba, Building a Foundation for Knowledge Creation. California Management Review, 40(3), Spring.

Osterloh, M. \& Frey, B.S. (2000). Motivation, Knowledge Transfer, and Organizational Forms. Organization Science, Sep.-Oct., 11(5): 538-550. Stable URL: http://links.jstor.org

Tsang, E. \& Kwan, K. (1999). Replication and theory develop- ment in organizational science: A critical realist perspective. Academy of Management Review, 24: 759-780.

Xavier, B.F.A. \& Bermejo, J. (2002). ¿Por qué se ha rechazado nuestro artículo?. Revista Española de Cardiología, 55(07), www.revespcardiol.org 


\title{
Alinhamento estratégico: o papel da informação na integração de propósito, processos e pessoas em Instituições no Brasil
}

\author{
Antonio Rodrigues de Andrade \& Aldo de Albuquerque Barreto \\ UNIRIO / UNAMA \\ E-mail: Prof.arandrade@gmail.com/Aldo.barreto@gmail.com
}

\begin{abstract}
Resumo
Não há gestão possível sem informação e ao lado de funções tradicionais, a empresa deve incorporar a função informacional. Como uma função de caráter transversal, não se limita somente ao ambiente interno da organização. Percorre órgão a órgão de uma forma transversal, para ligando-os entre si e ao ambiente externo. Para que o gerenciamento da informação seja eficaz, eficiente e efetivo no cumprimento de seu objetivo deve se saber com clareza o que é a informação para a empresa, quem a possui, como é conservada, quem é o responsável pelo gerenciamento, como controlar e utilizar a informação. Assim, esta pesquisa tem por objetivo avaliar a informação e seus fluxos como elementos integradores do propósito, do processo e das pessoas em organizações receptoras, processadoras e disseminadoras de infor-

mação no município do Rio de Janeiro. Ela insere-se no contexto gestão da informação no aspecto em que a informação e seus fluxos colaboram com os vários componentes do processo de alinhamento estratégico da organização. A metodologia utilizada teve um caráter qualitativo e de pesquisa exploratória e descritiva. Valeu-se de pesquisa de campo na forma de entrevistas estruturadas com profissionais da gestão das organizações pesquisadas. Através das entrevistas, buscouse conhecer as organizações pesquisadas em relação à integração entre propósito, processos e pessoas. A análise dos dados foi interpretativa. Constatou-se que as organizações pesquisadas, de maneira geral, não utilizam a informação em sua gestão com a mesma qualidade que captam e disseminam as informações objeto de seus objetivos organizacionais.
\end{abstract}

Palavras-chave: alinhamento estratégico; propósito; processo; pessoas; informação. 


\begin{abstract}
There could not be management without information and alongside the traditional functions of an organization and its incorporated informational function. Considering the function of lying across and not only limited to the organization's internal environment. For information management to be efficient and effective in meeting its goal they must be to know clearly what is the information concept for the company, who has it is , how it is conserved and who is responsible for managing, controlling and using it. Thus, this research aims to evaluate the information, and its integrating elements flows with the purpose to examine the process and people in the recipient organizations, also to observe its processors and disseminators in the municipa-

part of the information management aspect in the context of information flows and their work with the various components of the strategic alignment in the organization process. The methodology was qualitative, exploratory and descriptive.In the field, research was structured as interviews with professionals in the management of each organization surveyed. Through the interviews was intended to know the surveyed organizations regarding its integration between purpose, process and workers. Data analysis had an interpretive. The survey found that organizations in general do not use the information in its management with the same quality as they gather captured, and disseminated information used for its objectives and organizational goals.
\end{abstract} lity of Rio de Janeiro. This research is

Key-words: strategic alignment; purpose; process; people; information.

\title{
Introdução
}

\begin{abstract}
A vantagem competitiva das Organizações está passando a depender, cada vez mais, de sua capacidade de tomada de decisões, de gerar estratégias e transformar as estratégias em ações diárias, em que seus profissionais possam contribuir, gerando resultados significativos ao encontro de seus objetivos. Vemos a informação como objeto principal para que isso possa se concretizar.

A administração é a interpretação dos objetivos propostos pela empresa por meio do planejamento, organização, direção e controle de todos os esforços realizados em todas as áreas e em todos os níveis da organização, a fim de alcançar tais objetivos de maneira mais adequada à situação (Chiavenato, 1993).
\end{abstract}


Alinhamento estratégico: o papel da informação na integração de propósito, processos e pessoas em Instituições no Brasil

Cada empresa incorpora um modelo de gestão que, ao longo do tempo, vai sendo alterado e ajustando-se de forma a melhor contribuir com os seus objetivos. O modelo de gestão não é único nem rígido e varia de organização empresarial para organização empresarial, em função do desenvolvimento de variáveis internas e externas (Rodriguez \& Rodriguez, 2001).

A necessidade de as organizações promoverem o alinhamento de suas estratégias com os processos internos e os externos tem-se configurado como uma necessidade crescente. Além disso, a informação deve ser integrada aos produtos, serviços e, principalmente, às decisões. Essa integração torna-se função vital da gestão de qualquer empresa. Não há gestão possível sem informação.

A empresa possui uma dinâmica interação com seu meio ambiente, sejam clientes, fornecedores, concorrentes, entidades sindicais, órgãos governamentais e outros agentes externos. Além disso, possui uma estrutura de funcionamento composta por diversas unidades relacionadas entre si, que atuam de forma harmônica e estão orientadas para objetivos definidos, não só para a organização como para seus participantes (Porter, 1998).

A relevância que a informação assume, nesse contexto, dá-se na sustentação e no crescimento existente entre o sistema organizacional, o meio ambiente e seu funcionamento operacional. Um processo pelo qual a organização se informa sobre ela própria e sobre o seu ambiente, bem como informa o ambiente sobre ela própria. Isso implica em criação, comunicação, tratamento e memorização da informação. Além disso, o processo deve produzir resultados que permitam avaliar a qualidade da informação. Resultados quanto à quantidade, ao custo, ao tempo de geração e à sua utilidade para o usuário. A informação é um instrumento de integração fundamental, que necessita ser avaliada quanto ao impacto produzido nesse processo de integração organizacional.

As mudanças de mercado provocadas pelas alterações nas necessidades dos clientes fazem com que, a cada instante, as organizações tenham que se ajustar à nova realidade. Está no alinhamento estratégico o meio que a empresa possui para dar consistência entre planos, processos, ações e decisões que apoiem as estratégias, objetivos e metas globais da organização. A fim de torná-lo eficaz, faz-se necessário o entendimento das estratégias e metas, e a utilização de indicadores e informações complementares para possibilitar o planejamento, monitoramento, análise e melhoria nos setores de trabalho, 
nos principais processos e na organização como um todo. Nesse ponto, a informação desempenha um papel significativo (FPNQ, 2003).

Sendo assim, para o desenvolvimento e consecução de suas atribuições relacionadas ao planejamento, gerenciamento e execução, é necessário que o administrador das empresas tenha informações adequadas, específicas e pertinentes. A informação deve ser vista como o insumo básico para a realização das atividades do gestor, de forma que venha a contribuir para a tomada de decisão e efetiva melhoria no desempenho organizacional.

A Gestão Estratégica deve ser considerada como a criação, escolha e formulação da estratégia, a tradução em ação por meio da consecução das necessárias mudanças e, por fim, a monitoração e a avaliação da sua efetividade. A informação desempenha papel essencial na integração das três etapas, onde: (a) a informação na definição estratégica cria as condições para uma resposta competitiva mais eficaz da organização às exigências do ambiente; (b) a informação para a execução estratégica está relacionada à disseminação das definições estratégicas por toda a organização e contribuição à criação das condições para a sua implementação; e (c) o feedback da informação sobre o desempenho permite que reconheçam- se as necessidades de modificações e ajustes nas definições quando tornarem-se ineficazes (McGee e Prusak, 1994).

As informações, obtidas pelo monitoramento ambiental, subsidiarão a formulação estratégica da empresa, a definição de atuação dos processos e, consequentemente, das pessoas envolvidas. Embora, os estudos não abordem nenhuma empresa ou segmento econômico específico, ressaltam a sua importância para o processo de inteligência competitiva e organizacional desenvolvido ou por quem pretende desenvolvê-lo nas organizações.

A interação empresa - cliente, somente, será eficaz se o recebido e transmitido por ela for, efetivamente, percebido e aceito como tal pelos envolvidos no processo informacional. Isso vai ao encontro do apresentado por Barreto (1995) ao introduzir o conceito de assimilação da informação como um processo de interação entre os indivíduos e uma determinada estrutura de informação, possibilitando gerar uma modificação em seu estado cognitivo. Dessa forma, produz-se conhecimento que se relaciona, corretamente, com a informação recebida.

Barreto (1994) cunhou o termo estrutura significante quando, ao adaptar os conceitos de informação de Wersig, Nelling, Belkin e Robertson, apresentou o seu próprio conceito em que apresenta a informação como "estruturas 
Alinhamento estratégico: o papel da informação na integração de propósito, processos e pessoas em Instituições no Brasil

significantes com a competência de gerar conhecimento no indivíduo, em seu grupo, ou na sociedade.

Sempre presente em todos os períodos históricos, a informação tornou-se, ao final do século passado, um relevante fator de produção. Em um mercado cada vez mais globalizado e competitivo, a utilização da informação assume importante papel na orientação das estratégias das organizações. Vive-se uma fase cujas transformações aceleram-se nas tecnologias de informação, na comunicação e na configuração da economia.

O conhecimento da origem, da organização e da disseminação da informação deve ser encarado como condição fundamental para o crescimento das possibilidades de realizações estratégicas nas organizações. Por meio de um processo informacional alinhado aos objetivos organizacionais é que será possível, aos seus gestores, a interpretação, a transformação e a utilização da informação na tomada de decisão e nas escolhas estratégicas.

Assim, entende-se que a informação e, principalmente, a sua organização e o seu compartilhamento permitirão aos envolvidos, nas várias organizações públicas ou privadas, direta ou indiretamente, a prática do planejamento, monitoramento e controle de forma consistente.

Resumidamente, tudo isso nos leva a constatar a inexistência de um processo informacional sistematizado entre os vários atores responsáveis nas organizações, em que, fundamentalmente, o compartilhamento de informações e a utilização ótima da informação não são desenvolvidos.

Assim, esta pesquisa, tem por objetivo avaliar e apresentar o papel da informação como elemento integrador do propósito, do processo e das pessoas em organizações de captação, processamento e disseminação de informação por meio de um estudo de caso múltiplo. Ela insere-se no contexto gestão da informação no aspecto em que a informação e seus fluxos colaboram com os vários componentes do processo de alinhamento estratégico da organização. Com uma visão multidisciplinar analisa três Instituições Brasileiras quanto ao papel da informação no alinhamento estratégico.

\section{Método de estudo}

A metodologia utilizada teve um caráter qualitativo e de pesquisa exploratória e descritiva. Valeu-se de pesquisa de campo aplicada, na forma de entrevistas estruturadas, com profissionais da gestão das organizações pesquisadas 
e pesquisa bibliográfica e documental. Por meio da entrevista e documentos coletados, buscou-se conhecer as organizações pesquisadas quanto à integração entre propósito, processos e pessoas nas instituições que administram a captação, processamento e disseminação das informações. Foram selecionadas três instituições para a pesquisa todas em nível nacional: um Museu, uma Biblioteca e um Arquivo

A pesquisa de campo baseou-se nos procedimentos propostos por Alberti (1990). O primeiro procedimento é a identificação dos profissionais das empresas pesquisadas e em seguida, é feita uma sondagem para a realização da pesquisa e a formalização dos convites de participação. Foram consultados entre dois a cinco profissionais de cada Instituição pesquisada.

O roteiro de entrevista foi dividido em três partes considerando questões relacionadas com o propósito, os processos e as pessoas nas Instituições. Foram elaboradas dez questões para propósito relacionadas com planejamento estratégico, interação com os clientes/usuários e nível de inovação, quinze de processos abordando temas como modelo de gestão, uso de tecnologia da informação, conectividade, acesso e disponibilidade da informação e controle, por fim mais dez questões do tópico pessoas buscando identificar a captação, avaliação e capacitação de talentos.

As entrevistas com os gestores foram gravadas e transcritas. Foram, ainda, conferidas a fim de ser mantida a integridade da transcrição. No primeiro momento, a transcrição foi feita com o objetivo de concentração da fala do entrevistado nas respostas às perguntas elaboradas. No segundo momento, elaborou-se um ajuste nas respostas, considerando-se que, em certos momentos, algumas delas sobrepuseram-se a outras perguntas, ou foram respostas dadas em complemento a anteriores.

Concluídos esses procedimentos, o estudo apresenta interpretações objetivando avaliar e comentar um conjunto de informações para revisão, reflexão e interpretação do objeto do estudo, ou seja, a informação na integração de propósito, processos e pessoas. A análise dos dados foi interpretativa, tomando-se, por base, as informações relatadas pelos entrevistados considerando o corpo de conhecimentos pertinentes ao assunto nos campos das ciências de administração e da informação. 
Alinhamento estratégico: o papel da informação na integração de propósito, processos e pessoas em Instituições no Brasil

\section{Resultado da pesquisa}

O alinhamento estratégico é a essência da Gestão Estratégica, pois, é por meio dele, que haverá consistência entre planos, processos, ações e decisões para apoiar as estratégias, objetivos e metas globais da organização. Para que isso se realize, três elementos são considerados fundamentais: o propósito, os processos e as pessoas.

O primeiro componente para a definição da existência do alinhamento estratégico é o propósito. Nele, serão encontrados os elementos que permitirão avaliar a existência de uma formulação estratégica, bem como os mecanismos que permitirão à Organização proceder à integração por meio do desdobramento estratégico.

A classificação que esclarece as formas com que os gestores pensam sobre a realização de suas intenções e ações estratégicas são denominadas de racional, evolucionária e processual (Heijden, 2004)

A primeira delas, a abordagem racional, trata o pensamento e a ação separadamente. Esta abordagem é a que mais se aproxima de duas Instituições pesquisadas. O Arquivo e a Biblioteca apresentam elementos que permitem definir, como racional, a modelo de formulação e implementação estratégica das Instituições.

O Museu apresenta elementos mais próximos da abordagem processual: mais aberta ao ambiente e procurando ajustar-se conforme o que nele é percebido.

A abordagem processual, diferentemente das outras e, em especial, do racional, entende que é possível definir estratégias ótimas como o proposto pelo paradigma racional. Entretanto, para que isso se torne possível, as organizações devem tornar-se mais flexíveis, adaptáveis e capazes de aprender com seus próprios erros. O que é demonstrado pelo Museu, principalmente, quando se refere ao aprendizado que busca nas ações relacionadas com os seus clientes.

Duas Instituições, Museu e Arquivo Nacional, promovem a integração estratégica levando em consideração dois aspectos. O primeiro refere-se à informação definida no plano estratégico e desdobrada em objetivos e metas correspondentes e alinhadas com o plano inicial. O segundo refere-se às pessoas que participam do processo de planejamento. 
Cabe destacar que houve divergência de informações nas entrevistas realizadas na Biblioteca. Enquanto uma entrevistada informou sobre o planejamento estratégico da Instituição, a outra participante afirmava não reconhecer a existência de planejamento estratégico. Esta situação fragiliza a afirmação de que há desdobramento estratégico, pois ele se consolida com o conhecimento de todos na Organização a seu respeito.

Pode-se observar, no Museu, que a integração organizacional é fundamental ao alinhamento estratégico. Ela se dá através de reuniões constantes em todos os níveis, procurando garantir que todos tomem ciência e participem do movimento estratégico. As informações e as pessoas, em toda a Instituição, mobilizam-se para o cumprimento das operações e projetos vinculados com o plano estratégico de forma orquestrada.

No Arquivo, também, existe a preocupação de utilização da informação e da participação das pessoas. A busca da integração organizacional é uma preocupação da direção, que reúne a administração intermediária no processo de formulação estratégica, mas é garantida sua aplicação sistemática. A participação dos demais colaboradores da Instituição depende do comportamento das chefias em informá-los e recolherem suas informações para apresentação em fóruns superiores.

A comunicação por meio de Tecnologia da Informação não é explorada para a construção do alinhamento pelas três Instituições, que mais a utilizam para a operacionalização das ações e operações.

A busca de informações externas, principalmente, a do cliente, não é feita de forma proativa e, tampouco, a captura das informações recebidas é realizada de forma sistematizada pelas três Instituições. As informações são recebidas por canais instituídos como Fale Conosco, e-mails e caixa de sugestões no dia a dia. As três Instituições conhecem bem seus clientes, mas não os exploram no sentido de contribuírem com suas informações no processo estratégico. Mas, não pode ser ignorado que, ao ouvi-los, mesmo de forma reativa e com os meios que possuem, aproveitam as informações fornecidas para melhorias operacionais.

Todas se dizem inovadoras, mas isso ocorre com limitações, pois são organismos públicos, onde inovar não é uma prática constante e comum, embora demonstrem ações nesse sentido, principalmente, a Biblioteca e o Museu.

Quanto ao controle existente nas Instituições, ele é desenvolvido levandose em consideração indicadores estabelecidos para tal fim mas, na maioria, de 
Alinhamento estratégico: o papel da informação na integração de propósito, processos e pessoas em Instituições no Brasil

forma que satisfaçam as informações que devem estar contidas nos Relatórios de Gestão.

O planejamento existe nas Instituições por força dos planos plurianuais que devem ser desenvolvidos e dos orçamentos, que devem ser apresentados por imposições legais aos órgãos públicos federais. Contudo, a grande questão é se possuem um caráter estratégico.

O segundo componente para a definição da existência do alinhamento estratégico é o processo. Aqui, entendido como a forma de implementação da estratégia na Organização, bem como o controle de sua execução. Duas abordagens podem ser constituídas para a implementação estratégica. Uma delas é a adoção da orientação por processos e outra a abordagem por orientação funcional.

Pode-se constatar que as três Instituições adotam a abordagem orientada por função. Possuem uma estrutura organizacional hierarquizada e centralização no processo decisório, que confirma o modelo de gestão mecanicista.

Tanto o Instituição 2 - Arquivo quanto a Instituição 3 - Biblioteca possuem iniciativas de adoção da abordagem por processos. Inclusive, têm alguns processos mapeados mas, embrionários, não demonstram relevância para a sua análise.

Os aspectos relacionados com o item Processos referentes à implementação estratégica são: o desenho dos processos e definição de atividades/tarefas para a realização estratégica, o uso da Tecnologia da Informação aplicada na Organização e os fluxos de informação. Outros aspectos a serem considerados relacionam-se com o acompanhamento e o controle estratégico. São eles: a existência de indicadores de desempenho quanto à sua constituição e à sua utilização, bem como as formas de realização do acompanhamento e controle estratégico.

Tanto implementação e controle são elementos que, após a formulação estratégica, precisam ser definidos para que a organização conduza as ações necessárias ao alcance de seus objetivos e metas e, assim, adotar um modelo de gestão e fundamental.

A abordagem funcional, adotada pelas três Instituições, possui uma dinâmica informacional que ocorre entre os vários ambientes organizacionais. Os ambientes organizacionais estão nos níveis hierárquicos da Organização, ou seja, nível estratégico, nível tático e nível operacional. 
Nesse modelo, é comum a descida de fluxos pelos níveis hierárquicos, do estratégico ao operacional, onde a informação deve se propagar a fim de desenvolver a execução estratégica e construir a integração organizacional. E, ainda, subir fluxo de informações do nível operacional ao estratégico para acompanhamento e controle das operações e projetos organizacionais.

Observa-se, pela pesquisa desenvolvida, que a dinâmica informacional corresponde aos fluxos descritos, onde informações apresentadas nos planos, programas e projetos são desdobrados pela cadeia hierárquica e, através dela, sobem informações de controle por meio dos indicadores de desempenho apurados.

A pesquisa não se preocupou com a abrangência e aprofundamento das informações contidas nos planos desdobrados, bem como dos indicadores de desenvolvidos, ou seja, não foi objeto da pesquisa avaliar conteúdo e, sim, o movimento (processo) da realização estratégica. Nesse sentido, as Instituições pesquisadas, teoricamente, cumprem o estabelecido para a implementação estratégica.

O terceiro e último componente para a definição da existência do alinhamento estratégico está relacionado às pessoas. É nele em que serão encontrados os elementos que permitirão avaliar a existência de uma capacitação apropriada para a construção do alinhamento.

Apesar de as Instituições, cada uma à sua maneira, estimular a participação dos colaboradores no planejamento estratégico, no quesito capacitação orientada para a estratégia, todas apresentaram a mesma situação de inexistência de um plano de capacitação que busque atender o alinhamento estratégico especificamente

\section{Considerações finais}

Este trabalho procurou avaliar a informação aplicada ao alinhamento estratégico das Organizações com ênfase na relação entre o propósito, os processos e as pessoas em organizações de captação, processamento e disseminação de informação. Foram selecionadas uma Biblioteca, um Museu e um Arquivo para a pesquisa.

Ao longo do trabalho, procurou-se relacionar a dinâmica das três Instituições com o alinhamento estratégico para efeito da integração organizacional, tendo-se em vista a consecução de seus objetivos estratégicos. 
Alinhamento estratégico: o papel da informação na integração de propósito, processos e pessoas em Instituições no Brasil

As três Instituições pesquisadas apresentam uma forte influência no seu modelo de gestão tradicional por serem organismos públicos e estarem condicionadas às regulamentações inerentes a essa situação. Contudo, pôde-se observar, nas entrevistas realizadas, que existem ações institucionais que as aproximam de modelos mais contemporâneos de gestão.

Todas as três Instituições apresentam uma estrutura organizacional rígida, permanente e flexível imposta pelas regulamentações devidas, contudo, em duas delas, Museu e Biblioteca, desenvolveram-se mecanismos informais para a busca de maior eficiência e eficácia em suas ações, sem com isso ferir qualquer ditame legal.

Há uma preocupação das três Instituições que o sistema de comunicação seja tanto vertical quanto horizontal. Isso ficou claro nas entrevistas realizadas no Museu e no Arquivo, não tendo sido detectado com maior precisão na Biblioteca. Confiabilidade colocada sobre as regras e regulamentos formalizados por escrito.

Controles são exercidos por indicadores de desempenho constituídos para atividades consideradas importantes nas três Instituições. Mas, os resultados de medição não são comunicados, não são analisados criticamente. E, também, não são usados, sistematicamente, para as atividades de melhoria, de forma que toda a Instituição tome conhecimento e possa atuar na melhoria do desempenho organizacional.

A Instituição que parece estar mais sintonizada com o seu ambiente é o Museu. Em seguida, a Biblioteca e, depois, o Arquivo. Contudo, as três Instituições não possuem um sistema formal de coletar dados de satisfação e insatisfação do seu "cliente". Portanto, não têm condições de utilizar essas informações para melhoria.

Por fim, constatou-se que todas as Instituições utilizam a informação a seu jeito não ficando demonstrado um padrão quanto a sua utilização para o alinhamento estratégico entre elas. Embora existam esforços no sentido de buscar um alinhamento para a consecução estratégica não está na informação o componente principal para proporcionar a integração organizacional.

\section{Referências Bibliográficas}

Alberti, V. (1990). História oral: a experiência do Cpdoc. Rio de Janeiro: FGV. 
Barreto, A.A. (1994). A questão da informação. São Paulo Em Perspectiva, São Paulo, n. 4, v. 8, out./dez.

Barreto, A.A. (1995). Valor agregado: Aspectos conceituais. Seminário Internacional Valor Agregado à Informação. Rio de Janeiro: SENAI/CNI/ CIET.

Chiavenato, I. (1993). Introdução à Teoria Geral de Administração. São Paulo: Makrobooks.

Chiavenato, I. (2000). Administração: teoria, processo e prática. São Paulo: Makron Books.

FPNQ - Fundação Prêmio Nacional para a Qualidade. (2003). Primeiros passos para a excelência. Brasília: FPNQ.

Heijden, K.V.D. (2004). Planejamento de Cenários: a arte da conversação estratégica. Porto Alegre: Bookman.

Kaplan, R.S. \& Norton, D.P. (1997). A estratégia em ação: balanced scorecard. Rio de Janeiro: Campus.

McGee, J. \& Prusak, L. (1994). Gerenciamento estratégico da informação. Rio de Janeiro: Editora Campus.

Porter, M.E. (1998). A vantagem competitiva das nações. In C.A. Montgomery \& M.E. Porter, (Org) Estratégia: a busca da vantagem competitiva . Rio de Janeiro: Campus.

Rodriguez y Rodriguez, M.V. (2001). Gestão do Conhecimento: reinventando a empresa para uma sociedade baseada em valores intangíveis. Rio de Janeiro: IBPI Press. 


\title{
Likes para a ciência: divulgação científica e consumo de notícias na página I Fucking Love Science no Facebook
}

\author{
Talyta Singer \\ Universidade Federal da Bahia \\ E-mail: ytasinger@gmail.com
}

\begin{abstract}
Resumo
Este trabalho pretende analisar a distribuição de conteúdo científico em sites de rede social usando como estudo de caso a página I Fucking Love Science no Facebook. Criada em 2012, a página conta com 20 milhões de likes, superando

com vantagem outras publicações mais tradicionais. Os resultados apontam que mesmo que seja feito uso de humor e expressões pouco convencionais, a cobertura não se distingue de mídias mais tradicionais.
\end{abstract}

Palavras-chave: divulgação científica; Facebook; I Fucking Love Science.

\section{Resumo}

This work aims to analyze the distri- more traditional publications. The results bution of scientific content on social show that even if it is made use of hunetworking sites using as a case study the mor and unconventional expressions, copage I Fucking Love Science on Face- verage does not differ from the one on book. Founded in 2012, the page has 20 more traditional media.

million likes, surpassing advantageously

Palavras-chave: science communication; Facebook; I Fucking Love Science.

\section{A estudante que amava ciência}

$\mathrm{E}$

LISE Andrew, uma estudante de biologia britânica, então com 23 anos, criou a página I Fucking Love Science em março de 2012. Lá ela colocou todo o conteúdo sobre ciência que costumava publicar em seu perfil pessoal e no dia seguinte já acumulava mais de 1000 seguidores (Wills, 2013). 
Atualmente, a página conta com 20 milhões de fãs, superando com bastante vantagem outras instituições mais tradicionais como Discovery News $(5,5 \mathrm{mi}$ lhões), Scientific American (2,1 milhões) e mesmo o The New York Times (9,3 milhões).

O conteúdo das publicações compreende divulgação de resultado de pesquisas, fotos curiosas, quadrinhos e memes de conteúdo científico. A abordagem, mesmo nas publicações mais sérias, é divertida. Na definição de uma das responsáveis pela página, enquanto o noticiário de ciência se dedica a cobrir o que é importante ou digno de nota, o IFLS tenta descobrir o que as informações tem de "cool"(Fitts, 2014).

Além do Facebook, IFLS tem perfil no Twitter, ativo desde setembro de 2012, o tem pouco mais de 150 mil seguidores. O canal do YouTube tem 230 mil inscritos. O primeiro vídeo foi publicado em agosto de 2013 e na época circularam notícias de que poderia ser produzidos programas para televisão, para o Science Channel (Lewis, 2014). O canal não publica novos vídeos há onze meses, o que parece indicar que o projeto foi cancelado. A expansão do conteúdo em outras redes também foi uma tentativa de gerar receita, conforme indica Andrew em entrevista dada em 2013:

YouTube has a revenue share option, Facebook doesn't. The only way to make money is to sell merchandise. We sell T-shirts. I donate a lot of the money to charity, the rest is reinvested or used for expenses. I could be making a lot of money; sites offer to pay me to link to them exclusively, but I like our independence and don't want to lose our readers' trust. I have a full-time job in Toronto, handling the social media content of LabX [a media group]. I like the stability of a regular pay cheque. If I were a starving student, I might have said yes to some offers, but I can afford to pick and choose. (Teeman, online, 2013)

O site foi lançado entre setembro e outubro de 2012. Elise disse que o criou para publicar notícias com sua própria voz, ao invés de apenas compartilhar conteúdos criados por outras pessoas (Teeman, 2013). Muitas das publicações da página não compartilhadas diretamente do site, onde as notícias são assinadas por membros de uma equipe que a falta de um expediente não permite identificar com clareza. 
Likes para a ciência: divulgação científica e consumo de notícias na página I

Uma das motivações de Andrews para manter a página é o tipo de respostas positivas que recebe. Desde professores que aproveitam alguns dos conteúdos para levar humor a salas de aula (Stoianovici, 2013) a adultos que gostam de acompanhar o que acontece na ciência, até mesmo cientistas que se atualizam sobre outras áreas de conhecimento (Teeman, 2013).

\section{Visibilidade e críticas}

O rápido crescimento da página fez com que ela fosse notícia em diversas publicações, incluindo Guardian (Teeman, 2013), BBC (Stoianovici, 2013), Mashable (Wills, 2013) e o assunto de capa da Columbia Journalism Review em setembro de 2014. Essa atenção dada ela imprensa, algumas imprecisões em informações divulgadas e o retrato feito pela CJR foram motivo de críticas feitas por Nadia Drake no site da Knight Science Journalism (Drake, 2014). Entre as críticas, já foi dito que a abordagem da IFLS e de outros veículos de divulgação científica é pouco crítica, confunde natureza com ciência, além de usar técnicas de click-baiting, técnica usada para gerar tráfego em sites a partir de textos provocativos e manchetes publicas em sites de rede social. Falando ao News Statement sobre imprecisões nas informações, Andrew se defendeu das críticas:

I've never shown things that were inaccurate. Somebody tried to troll Reddit and faked a Neil Degrasse Tyson quote, and I shared it not realising it was a fake. With quotes it's much more difficult to track; it's something that happened to go online, and it's difficult to keep track of who said what and when. I'm using quotes less now. (Woolf, online, 2012)

O maior problema, porém, parecem ser a falta de crédito ou referências no conteúdo divulgado, principalmente imagens. Alex Wild, que escreve para o blog Conpound Eye da Scientific American apresentou o problema (Wild, 2013). Após ver uma de suas fotos ser utilizada pela página sem créditos, ele analisou 100 fotos publicadas pela página e descobriu que 59\% não tinham qualquer crédito ou indicação de fonte. 


\section{Divulgação científica e consumo de informação no Facebook}

O Facebook é o maior site de rede social (SRS) da atualidade com mais de 1,3 bilhão de perfis ativos. Além de manterem seus perfis, os usuários passam grandes períodos de tempo conectados na plataforma. Pesquisa da empresa de análise de dados Flurry estimou que o Facebook ocupa 17\% do tempo gasto em dispositivos móveis, conta 1,5\% do Twitter e 3\% de aplicativos de notícias em geral (Khalaf, 2014).

Grande parte do tempo gasto no Facebook, assim como em outros SRS, é usado para consumo de notícias. Em 2014, a Pew Research identificou metade dos usuários do Facebook e do Twitter usam redes sociais para encontrar notícias, assim como $62 \%$ dos usuários do Reddit. E para muitos destes usuários o ambiente é mais importante do que a fonte, uma vez que $78 \%$ das pessoas que consumem notícias no Facebook usam essa rede social por outros motivos, que não consumir notícias. Apenas 34\% segue páginas de organizações jornalísticas ou jornalistas, o que sugere que a maior parte do conteúdo vem de sua rede de amigos e dos conteúdos que estes amigos curtem e compartilham (Malsa \& Mitchell, 2014).

Apesar do Facebook já ter seu lugar em algumas áreas da pesquisa social como sociabilidade e publicidade online, as pesquisas de distribuição de notícias na plataforma ainda estão em estágio inicial (Caers et al, 2013). Muito em função da própria estrutura que não permite a recuperação fácil do conteúdo e uma vez que propõe um consumo do fluxo de informação pautada no ao vivo (Kaun \& Stiernstedt, 2014).

Deste modo, para compreender o resultados da pesquisa nos apoiaremos na longa tradição de pesquisas que acompanham como diferentes mídias tratam dos temas de ciência e tecnologia. É o caso dos trabalhos de Auberguini (2007) e Ricci (2010). Estudos mais recentes mostram as relações entre a divulgação científica e as novas mídias, em especial Liang et al. (2014) e Veltri (2013).

\section{Coleta de dados}

Inicialmente, a proposta consistia em analisar 30 dias de publicações feitas na páginas entre dezembro de 2014 e março de 2015 selecionadas através de um calendário aleatório. Para a coleta do dados foi usado o scraper de- 
Likes para a ciência: divulgação científica e consumo de notícias na página I

senvolvido por Norah Abokhodair, ferramenta que extrai informações de uma página web. Entretanto, a ferramenta apenas captura o texto publicado diretamente no Facebook. No caso do IFLS, a maior parte do conteúdo textual está na visualização dos links compartilhados do site, sendo os textos publicados diretamente no Facebook comentários mais vagos que não permitem identificar $\mathrm{o}$ assunto tratado.

Os textos foram então capturados diretamente da página, mas não foi possível resgatar completamente o conteúdo, o que fez com que a amostra fosse reduzida a um mês de publicação contínua entre 12 de fevereiro de 2015 e 12 de março de 2015, resultando em 204 itens. As informações catalogadas foram data da publicação, texto publicado diretamente no Facebook, título do link quando compartilhado de outro site, título da imagem, contagem de likes, comentários e compartilhamentos. A amostra final foi composta por 202 itens, uma vez que em duas publicações não foi possível registrar a contagem de likes, comentários e compartilhamentos em função de uma mudança no layout do Facebook. A coleta das publicações e a contagem das interações foram feitas no dia 29 de março de 2015.

A segunda etapa consistiu em classificar os posts a partir do seu conteúdo explícito. As categorias foram criadas a partir de nossas expectativas e adaptadas a partir dos conteúdos encontrados. A classificação final é:

1. Conteúdo: Notícia, Propaganda, Imagem e vídeo, Infografia, Humor, Citação ou Campanha.

2. Área científica: O conteúdo, informativo ou não, foi classificado de acordo com a área científica da qual ele fazia referência. Encontramos 16 áreas representadas, a saber: Agricultura, Arqueologia, Astronomia, Biologia, Engenharia/Tecnologia, Física, Geologia, História da Ciência, Letras/Linguística, Matemática, Medicina, Meio Ambiente, Método, Nutrição, Paleontologia e Química.

3. Pessoas citadas: Também foram identificadas as pessoas citadas nas publicações, cientistas ou não.

4. Análise da rede da página: Outra etapa da coleta foi a extração de dados através do Netvizz (Rieder, 2013). A rede da página compreende outras páginas curtidas pela IFLS e páginas que curtem a IFLS. O objetivo desta análise era observar o posicionamento da IFLS frente a outras páginas e observar como é o espaço que ela ocupa dentro desta rede. 


\section{Resultados}

Tipicamente, os conteúdos publicados pela página são link para o site IFLS ou imagens com algum comentário curto ou expressão de sentimento, de modo que o Facebook seja uma porta de entrada para o conteúdo do site. Os comentários que apresentam funcionam mais como legendas com informações adicionais, como nos exemplos abaixo:

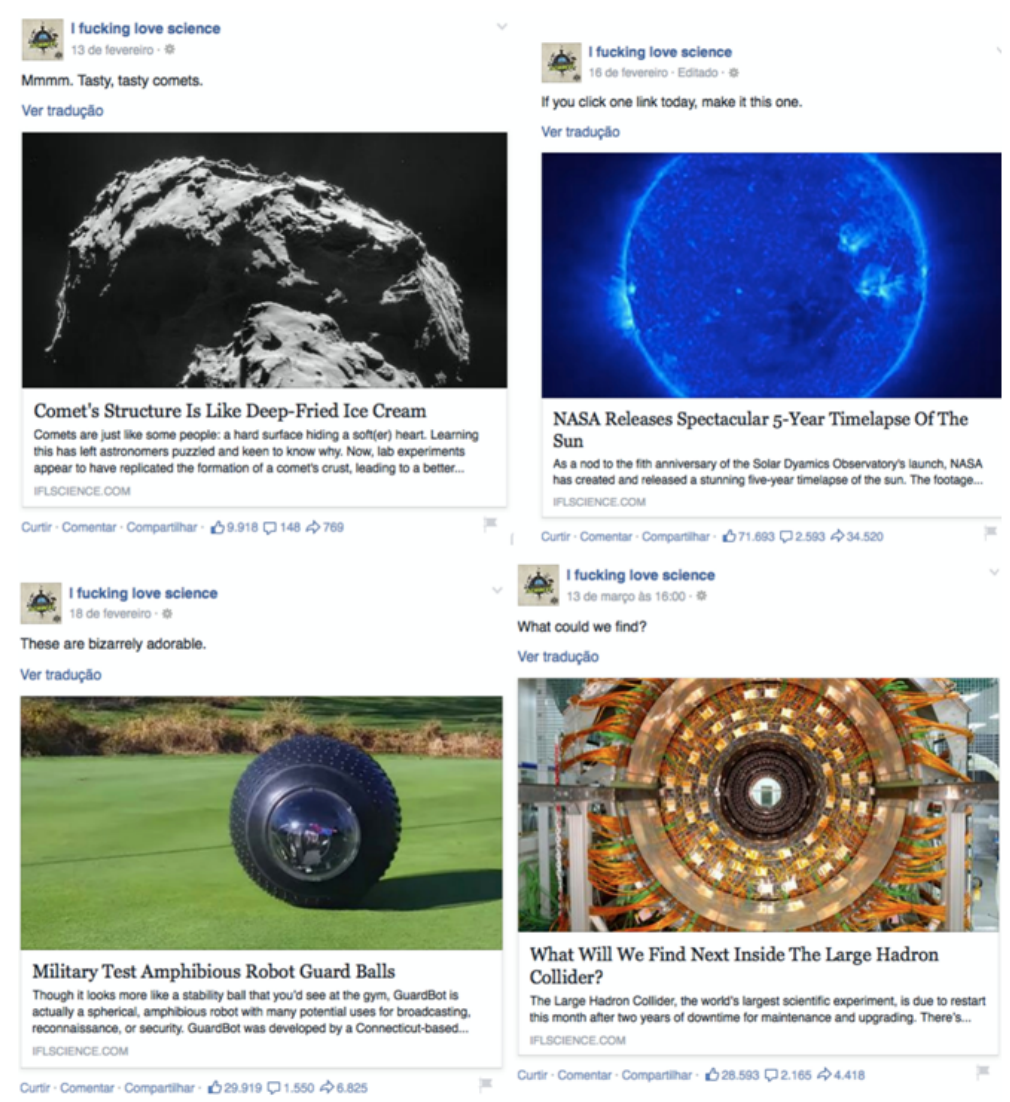

Figura 1 - Publicações da página I Fucking Love Science Fonte: Página I Fucking Love Science no Facebook 
Likes para a ciência: divulgação científica e consumo de notícias na página I Fucking Love Science no Facebook

A maior parte do conteúdo publicado pela página no período estudado é de notícias, que somam $64 \%$ das publicações. A divisão dos conteúdos por tipo de conteúdo é a seguinte:

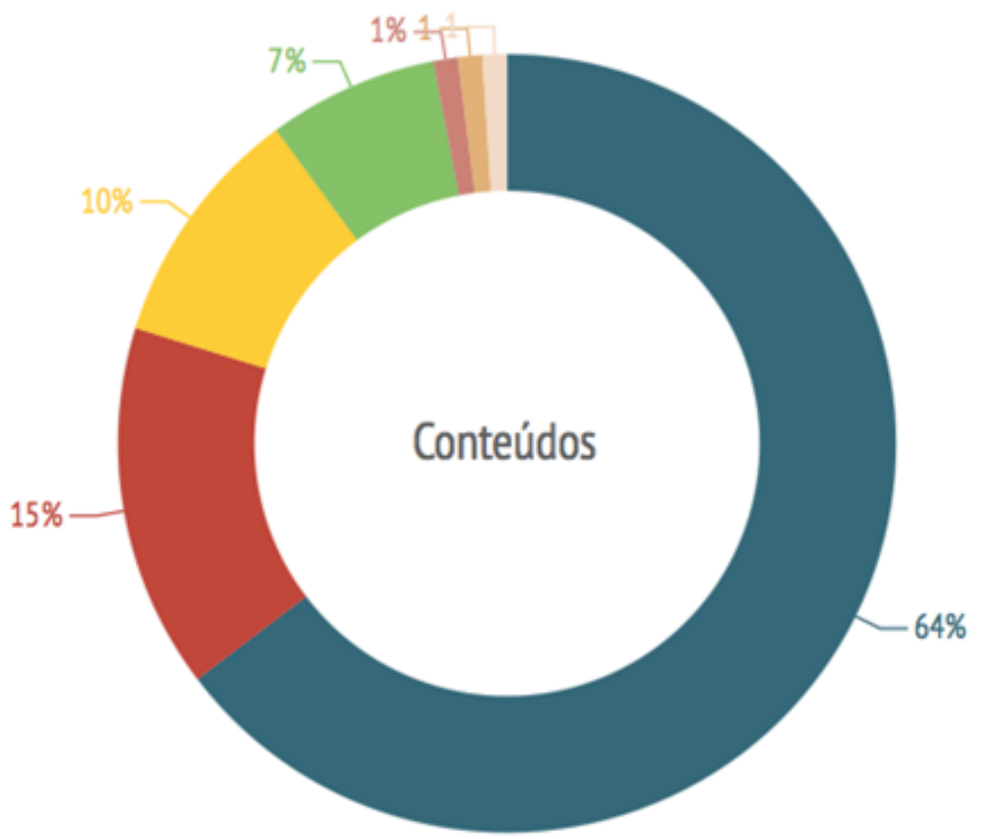

\section{Notícia Infografia Humor Imagem/Video Propaganda}

\section{Citação}

Figura 2 - Tipos de conteúdo

Elaboração própria

A incidência de notícias ou de publicações humorísticas varia de acordo com a área científica em destaque. Conteúdos ligados a Medicina e Astronomia eram mais frequentemente notícias, enquanto que conteúdos das áreas de Física, Matemática e Método científico tinham maior incidência de infogra- 
fias. Química é a área científica que mais vezes foi retratada em tom humorístico.

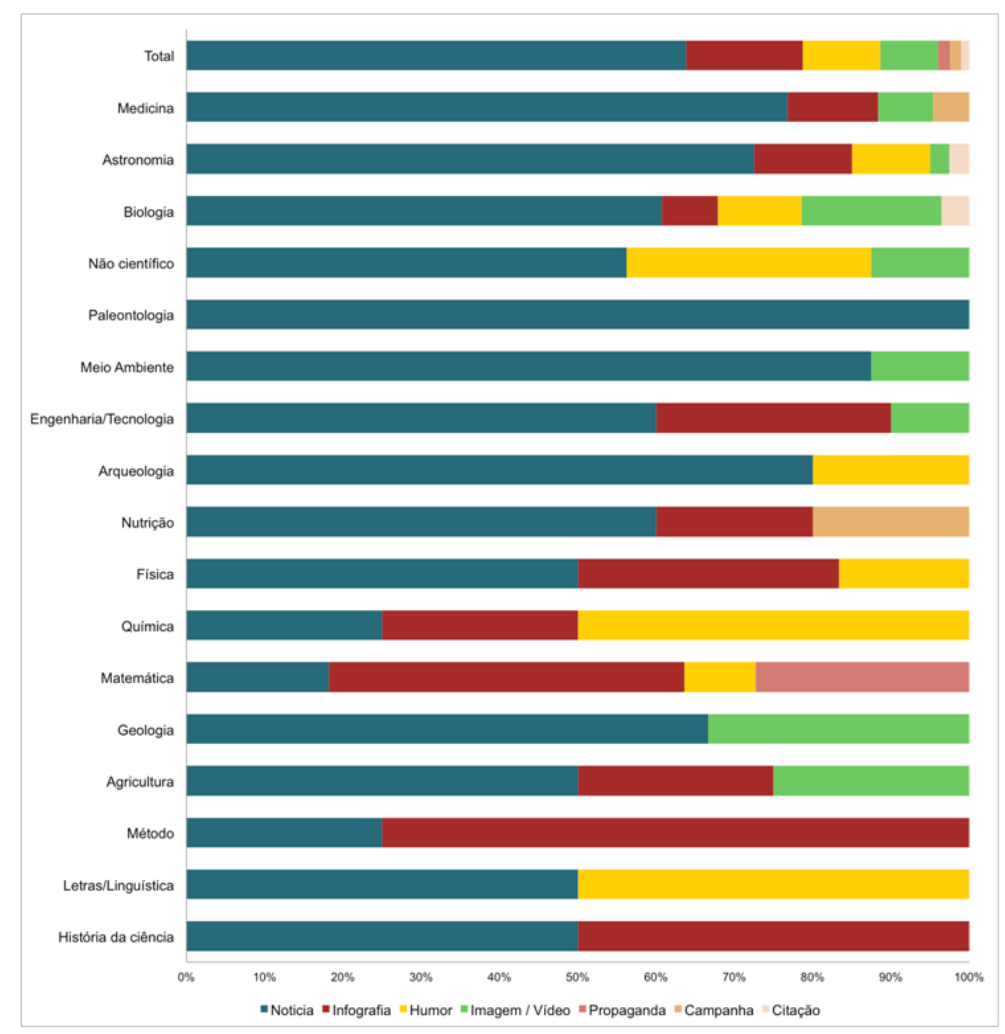

Figura 3 - Tipo de conteúdo por área científica Elaboração própria

Dentre 2020 publicações, 27 citam pessoas nominalmente. Ao todo são citados 37 cientistas, 2 cosmonautas, 2 comediantes, 1 pescador, Bill Nye, the Science Guy, Leonard Nimoy, o ator que interpretou Capitão Spock na série clássica de Star Trek, e o Capitão Kirk. Apenas 3 pessoas são citadas mais de duas vezes. $\mathrm{O}$ astrônomo Neil deGrasse Tyson, com quatro citações, lidera a lista. Ada Lovelace e Marie Curie são citadas três vezes. 
Likes para a ciência: divulgação científica e consumo de notícias na página I Fucking Love Science no Facebook

Analisamos ainda como as interações se distribuíam pela publicações e encontramos resultados interessantes. No primeiro gráfico comparamos a quantidade de posts por área científica em comparação com os índices de interação média que a categoria recebeu. Para calcular a interação média, somamos as contagens de likes, comentários e compartilhamentos e dividimos pela quantidade de publicações que cada uma das áreas científicas recebeu.

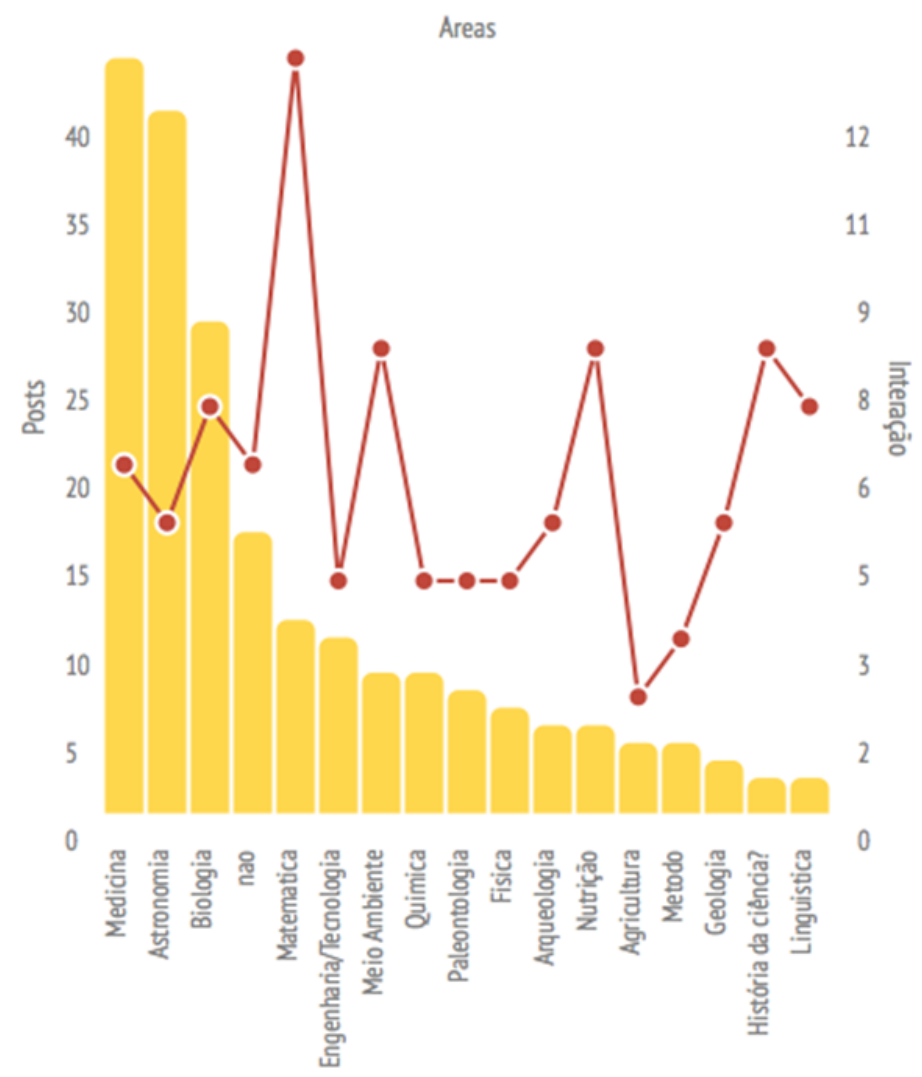

Posts

$$
\text { Interação }
$$

Figura 4 - Interação médias das publicações por área científica Elaboração própria 
Comparamos também a quantidade de posts por tipo de conteúdo e os índices de interação que cada um recebeu, como mostra a imagem abaixo:

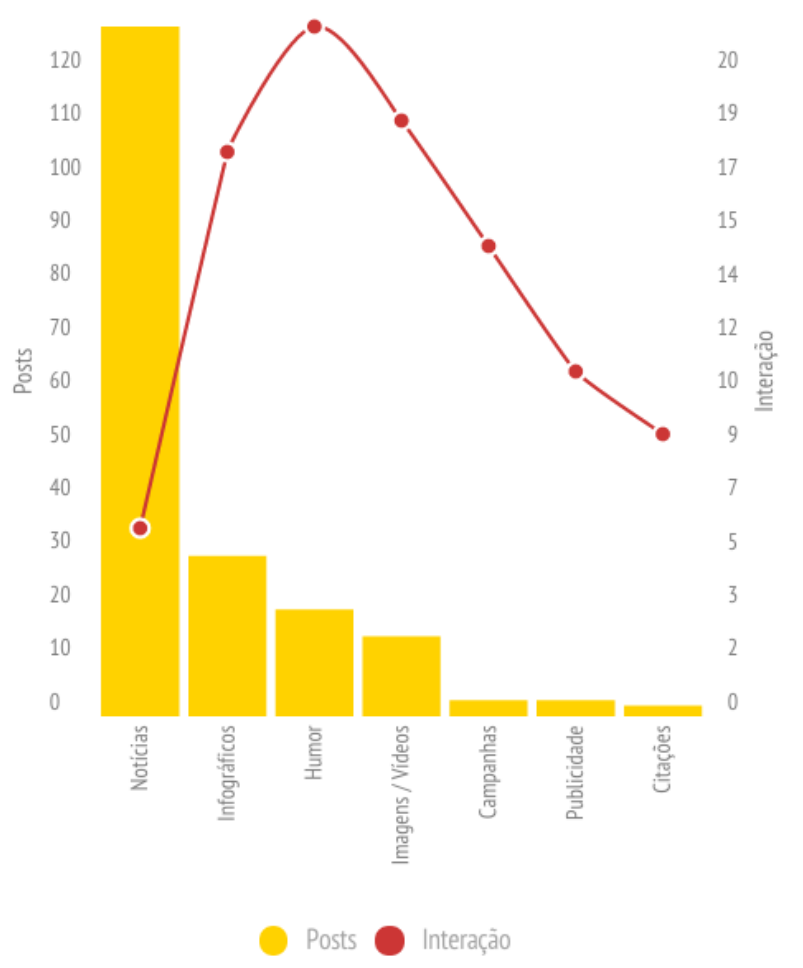

Figura 5 - Interação média dos posts por tipo de conteúdo

Por fim apresentamos um grafo que mostra a rede da página. Foi possível identificar sete diferentes tipos de páginas, representados pelas sete diferentes cores. A quantidade de likes que cada página recebeu define o seu tamanho na rede e suas relações com outras páginas definem sua posição. Como a rede foi gerada a partir da IFLS ela ocupa uma posição central, já que se relaciona com a maioria das páginas visualizadas e em maior tamanho por receber mais curtidas.

Analisando os grupos é possível perceber uma concentração de páginas de temática ambiental relacionadas com preservação marinha. No lado oposto da 
Likes para a ciência: divulgação científica e consumo de notícias na página I

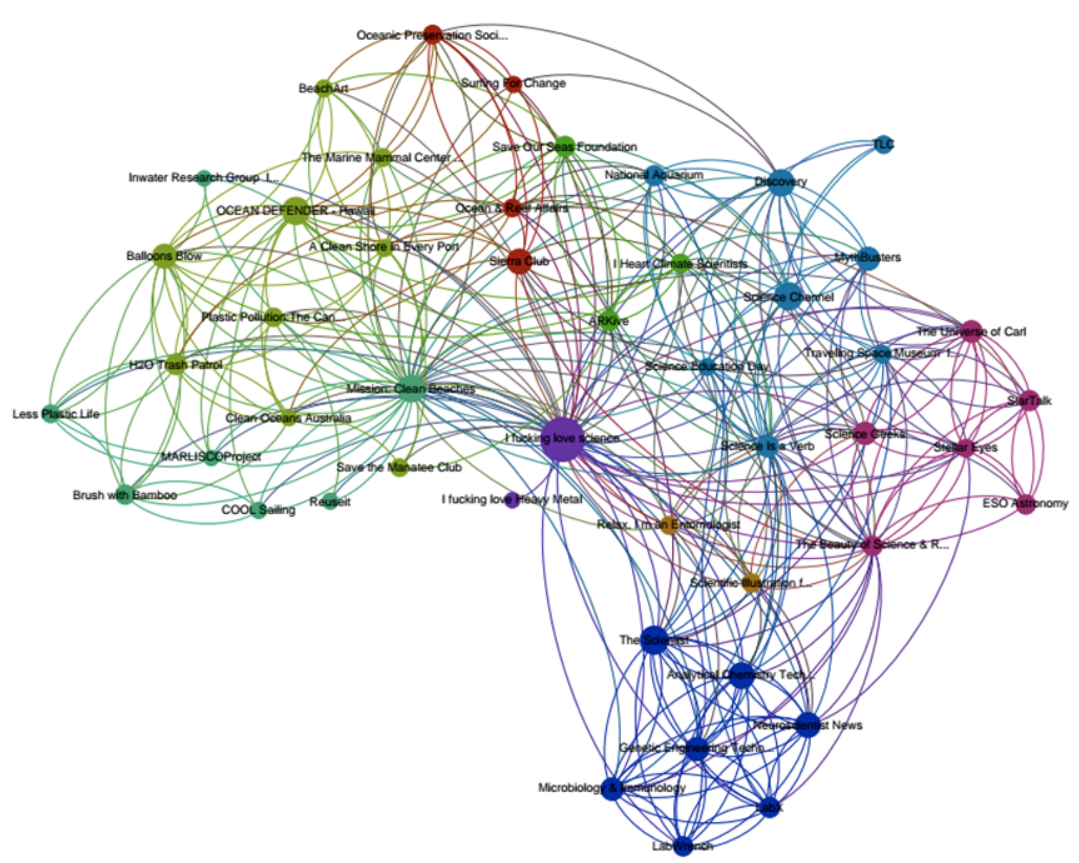

Figura 6 - Rede da página IFLS

imagem podemos ver as páginas de divulgação científica que formam três grupos. Concentradas na parte de baixo da imagem páginas ligadas a instituições mais tradicionais, algumas delas parte do Media X Lab empresa onde trabalha Elise Andrew. Do lado direito, na parte superior, em azul páginas de divulgação científica com perfil mais educativo como o Science Channel e Myth Busters. Science is a Verb é uma página que também parece funcionar como ponto de acesso e liga estes dois grupos. Finalmente, ocupando a parte direita dois grupos concentram páginas de divulgação científica mais divertidas. Em rosa um grupo de páginas ligadas à astronomia e em laranja páginas onde a maior parte dos conteúdos é de ilustrações. 


\section{Discussão}

A partir dos resultados encontrados podemos dizer que a página I Fucking Love Science se ocupa primariamente de noticiar, informar e compartilhar conteúdo humorístico relacionados às Ciências Exatas, Biológicas e da Saúde. Engenharias e Ciências Agrárias também são representadas, mas apenas quatro assuntos das área de Letras, Artes e Humanidadess foram registrados: Arqueologia, Método Científico e Letras/Linguística e História da Ciência, todos com pequeno número de conteúdos. É importante notar que registramos os conteúdos relacionados à método na área de humanas porque todos podem ser inscritos em áreas mais próximas a filosofia da ciência. Nominalmente, não é citado nenhum cientista destas áreas. A concentração na divulgação das ditas ciências duras já foi observada em outros trabalhos (Auberguini, 2007; Shaffer, 2010).

A concentração temática também pode ser observada nos cientistas mais citados. Neil DeGrasse Tyson, além de cientista, é uma figura midiática importante. Ele é o apresentador da reedição da série Cosmos e tem três milhões de seguidores no Twitter. A grande maioria dos cientistas citados nominalmente tem pesquisas de grande repercussão histórica como Marie Curie e Albert Einsten ou de grande visibilidade midiática como Jane Goodall e Stephen Hawking. O mesmo comportamento tem precedentes na literatura e é conhecido como "Saganization" effect (Liang et al, 2014), em referência a Carl Sagan, e acontece quando cientistas mais engajados midiaticamente acabam tendo mais impacto acadêmico do que seus colegas menos engajados.

O modo de narrar utilizado pela página e os formatos de conteúdo utilizados nos permitem dizer que se trata de uma página de jornalismo científico, ainda que ocorram publicações voltadas para o humor, principalmente se assumirmos o jornalismo científico em termos de uma atividade educativa e de popularização de conhecimento como faz José Marques de Melo (1982, p. 21):

E o que deve ser o jornalismo científico? Deve ser uma atividade principalmente educativa. [...] Deve promover a popularização do conhecimento que está sendo produzido nas nossas universidades e centros de pesquisa, de modo a contribuir para a superação dos muitos problemas que o povo enfrenta. Deve utilizar linguagem capaz de permitir o entendimento das informações pelo ci- 
Likes para a ciência: divulgação científica e consumo de notícias na página I

dadão comum. Deve gerar o desejo pelo conhecimento científico permanente, despertando interesse pelos processos científicos e não pelos fatos isolados e seus personagens.

A seleção de conteúdos da página parece atender a critérios de noticiabilidade variados, incluindo senso de oportunidade, timing, impacto, significado, pioneirismo, interesse humano, personagens célebres, proximidade, necessidades culturas e necessidade de conhecimento (Epstein, 2007).

As diferenças registradas entre a concentração de publicações e os maiores índice de interação podem funcionar como boas medidas para compreender que a página busca publicar conteúdo de qualidade ao invés de apenas alimentar seus seguidores com os tipos de conteúdos que geram mais interação. A maior parte das interações acontecem nos conteúdos humorísticas, mas não é este tipo de conteúdo que domina as publicações.

Vale destacar que isso não parece ser um impedimento ao modelo de negócios assumido pela página, uma vez que os conteúdos relacionados à Matemática geraram os maiores índices de interação, sendo que a maior parte deles fazia referencia ao Dia do Pi, celebrado em 14 de março, quando a data do calendário corresponde a primeira sequência de números da constante matemática $p i=3,1415$ e alguns deles direcionavam à loja IFLS que vendia camisetas comemorativas. Todas as propagandas registradas se referem à esta situação.

A página também não se furta de aderir a campanhas como é o caso das publicações contra o movimento anti-vacina e solicitando que a rede de fastfood Subway altere a receita de seus pães.

A grande visibilidade que os posts alcançam também merece nota. No período estudado a página acumulou 22 milhões de interações somando likes, comentários e compartilhamentos. O grande número de interações aponta que os conteúdos são recebidos também por pessoas que não seguem a página. O feed de notícias da plataforma personaliza o conteúdo exibido para cada usuário a partir de seu histórico de navegação e preferências. E do mesmo modo que nem todos os 20 milhões de fãs recebam todas as publicações, é possível dizer que sejam visualizadas por um número maior de pessoas graças ao volume de interações.

É necessário comentar o Facebook ao mesmo tempo em que concentra um grande número de pessoas dificulta o uso das informações para pesquisa. A falta de ferramentas que permitam extrair dados em maior profundidade e 
recuperar conteúdos passados é um empecilho para compreender como funcionam os mecanismos de interação ao longo do tempo. Conforme avança a importância da plataforma para distribuição de notícias será necessário desenvolver novas ferramentas.

Para finalizar, algumas limitações dos resultados da pesquisa devem ser mencionadas. A análise dá conta de um mês das publicações de uma página específica. Ainda que o número de publicações e de interações sejam altos, os resultados não podem ser generalizados para fora de seu contexto inicial. Para compreender melhor os mecanismos de divulgação científica usados pelo I Fucking Love Science seria ideal avaliar os textos completos publicados no site, que em função de espaço e foco, este artigo não avaliou. Além disso, não fizemos qualquer avaliação da recepção dos conteúdos que não fosse a contagem das interações. Em estudos posteriores pode ser interessante avaliar o que dizem os comentários e se a página interage diretamente com seus seguidores, promovendo o diálogo ou ampliando discussões.

\section{Referências bibliográficas}

Abokhodair, N. (s.d.). Facebook post browser. Disponível em: http://groupbrowser.azurewebsites.net.

American Press Institute (2015). How Millennials Get News: Inside the habits of America's first digital generation. Disponível em: www.americanpressinstitute.org.

Rieder, B. (2013). Studying Facebook via data extraction: the Netvizz application. WebSci '13 Proceedings of the 5th Annual ACM Web Science Conference: 346-355. New York: ACM.

Cacciatore, M.A.; Anderson, A.A.; Choi, D.H.; Brossard, D.; Scheufele, D.A.; Liang, X.; Ladwig, P.J.; Xenos, M. \& Dudo, A. (2012). Coverage of emerging technologies: A comparison between print and online media. New Media \& Society, 14(6): 1039-1059.

Caers, R. \& De Feyter, T. (2013). Facebook: A literature review. New Media \& Society, 15(6): 982-1002.

Drake, N. (2014, 04 de setembro). Guest Post: Elise Andrew, science popularizer with a spotty attribution record, gets a pass from CJR. Knight Science Journalism. Disponível em: https://ksj.mit.edu. 
Likes para a ciência: divulgação científica e consumo de notícias na página I

Epstein, I. (2007). Quando um fato se transforma em notícia no jornalismo e na ciência. Comunicação e Sociedade, 28(27): 159-179.

Fitts, A. (2014, setembro). Do you know Elise Andrew?. Columbia Journalism Review. Disponível em: www.cjr.org.

Khalaf, S. (2014, 01 de abril). Apps Solidify Leadership Six Years into the Mobile Revolution. Flurry. Disponível em: www.flurry.com.

Lewis, T. (2014, 10 de março). Craig Ferguson to Produce New Series 'I Fing Love Science'. Scientific American. Disponível em: www.scientificamerican.com.

Liang, X.; Su, L.Y.; Yeo, K.S.; Scheufele, D.A.; Brossard, D.; Xenos, M.; Nealey, P. \& Corley, E. (2014). Building Buzz: (Scientists) Communicating Science in New Media Environments. Journalism \& Mass Communication Quarterly, 91(4): 772-791.

Marques de melo, J. (1982). Impasses do jornalismo científico: notas para o debate. Comunicação e Sociedade, IV(7): 19-24. São Paulo.

Matsa, K.E. \& Mitchell, A. (2014, 26 de março). 8 Key Takeaways about Social Media and News. Pew Journalism. Disponível em: www.journalism.org.

Ricci, O. (2010) Technology for everyone: representations of technology in popular Italian scientific magazines. Public Understanding of Science, 19(5): 578-589.

Schäfer, M.S. (2010) Taking stock: A meta-analysis of studies on the media's coverage of science. Public Understanding of Science, 21(6): 650-663.

Stoianovici, A. (2013, 25 de janeiro). Mad about science. Interview with Elise Andrew, creator of I Fucking Love Science. BBC Science World. Disponível em: www.scienceworld.ro.

Teeman, T. (2014, 13 de outubro). Why millions love Elise Andrew's science page. The Guardian. Disponível em: www.theguardian.com.

Veltri, G.A. (2012). Microblogging and nanotweets: Nanotechnology on Twitter. Public Understanding of Science, 22 (7), 832-849, 2012.

Wild, A. (2013, 23 de abril). Facebook's "I F*cking Love Science" does not f*cking love artists. Scientific American. Disponível em: http://blogs.scientificamerican.com. 
Wills, A. (2013, 11 de setembro). Why Everyone F*cking Loves Science and Elise Andrew. Mashable. Disponível em http://mashable.com.

Woolf, N. (2012, 12 de dezembro). Nick Elise Andrew: "There is a lot of pseudo-science and nonsense out there on the internet". News Statement. Disponível em: www.newstatesman.com. 


\title{
A faixa infanto-juvenil como público da ciência e a ciência que lhes é proposta
}

\author{
Carlos Alberto de Carvalho \& Luiza Lages de Souza Ramos \\ Universidade Federal de Minas Gerais \\ E-mail: carloscarvalho0209@gmail.com/ luizalsramosegmail.com
}

\begin{abstract}
Resumo
$\mathrm{O}$ artigo analisa narrativas sobre ciência ber que imagem de ciência as narrativas em três revistas brasileiras, Ciência Hoje, projetam e em que medida visões pedaCiência Hoje das Crianças e Superinte- gogizantes são adotadas como estratégia ressante, com foco na destinação a públi- de aproximação com os públicos refericos infanto-juvenis. Interessa-nos perce- dos.

Palavras-chave: Ciência; Narrativas; Público Infanto-Juvenil; Revista.
\end{abstract}

\section{Resumo}

The article analyzes narratives about sci- interest is to realize what science image ence in three Brazilian journals: Science those narratives produce, and to what exToday, Science Today for Children and tent pedagogical views are adopted as a Superinteressante, focusing on destina- strategy of rapprochement with the afotion to children and youth audiences. Our rementioned audiences.

Palavras-chave: Science; narratives; Public Children and Youth; Magazine.

\section{Imaginário e aprendizado das ciências}

alfabetização científica é uma ideia que nasceu em uma discussão pro-
posta por John Dewey (1934) sobre a necessidade de que os jovens fos-
sem ensinados, durante os anos escolares, a adquirir uma atitude científica.
Para o pesquisador e educador estadunidense, esse movimento ajudaria as 
pessoas a pensar de modo racional e elucidado sobre potenciais problemas que pudessem surgir ao longo de suas vidas.

Durant (2005) explica que, desde então, o termo "designa o que o público em geral deveria saber a respeito da ciência, e a difusão do seu uso reflete uma preocupação acerca dos sistemas educacionais vigentes" (Durant, 2005, p. 13). Para Miller (2005), a comunidade científica, com interesses próprios, tendia a manter a definição de alfabetização científica sob sua autoridade, estipulando uma agenda construída internamente, da ciência para o público.

Durant (2005) descreve três abordagens centrais para a alfabetização científica - todas problemáticas. A primeira, com foco no conteúdo científico, considera que a atividade envolve saber muito sobre ciência: saber o suficiente e saber cada vez mais. Mas, considerando saber muitos fatos ser diferente de ter um bom nível de compreensão da ciência, ele não considera o conhecimento factual a resposta para a alfabetização científica.

Latour (2000) usa o conceito de caixa-preta para trabalhar a dicotomia entre a ciência em construção e a ciência pronta. A caixa-preta seria a marca da exatidão, da ciência pronta. Ela engendra a substituição de questões muito complexas, anteriormente investigadas, por um elemento fixo, dado como certo e pelo qual os pesquisadores passam sem abrir. As caixas se mantêm fechadas para que a atividade científica não se torne impossível. Mas as marcas da ciência pronta são obras da ciência em construção. "Incerteza, trabalho, decisões, concorrência, controvérsias, é isso que vemos quando fazemos um flashback das caixas-pretas certinhas, frias, indubitáveis para o seu passado recente" (Latour, 2000, p. 16).

Para Latour (2000), falar sobre ciência significa abrir as caixas-pretas, falar sobre a ciência em construção. Falar da ciência pronta seria não só reducionista, como possivelmente mostrar às pessoas o que elas já conhecem. Incluindo ao escopo uma dimensão pedagogizante, a não abertura das caixas-pretas implicaria na não inclusão da dimensão incerta, mutável e transformadora da ciência - que nunca se mostrou pronta e intocável na história da humanidade. Seria ignorar a história e as qualidades inerentes à ciência, processos pelos quais um futuro cientista teria que percorrer.

A partir da perspectiva da construção da ciência, entramos na segunda e terceira abordagens possíveis à alfabetização científica. A segunda sendo saber como a ciência funciona. Com ênfase nos processos, os alunos deveriam aprender ciência a praticando. Durant (2005) toma emprestada a avaliação 
A faixa infanto-juvenil como público da ciência e a ciência que lhes é proposta

de outro pesquisador conterrâneo, Jon Miller, para aquela que seria uma pessoa cientificamente alfabetizada: a) possuir um vocabulário básico de termos e conceitos científicos; b) compreender os processos ou métodos científicos para colocar em teste nossos modelos de realidade; c) compreender o impacto da ciência e da tecnologia sobre a sociedade. O que o autor aponta é que, até para os cientistas, há muita dificuldade em entender de fato esses processos, que, como os fatos, são impuros e heterogêneos.

A terceira e última abordagem recai sobre saber como a ciência realmente funciona (com suas impurezas e constantes transformações). O processo social da produção do conhecimento científico envolve um conjunto de conhecimentos existentes; um cientista que identifica um problema ou uma possibilidade de contribuição para o corpus; a condução de um trabalho; a descrição do trabalho; o julgamento do trabalho; e a entrada do trabalho no corpus de conhecimento existente (Durant, 2005). Para o autor, a falha mais séria do ponto de vista usual é justamente projetar as qualidades do conhecimento científico sobre os cientistas, quando este deveria ser um trabalho objetivo, aberto e produzido a partir de métodos estipulados em comunidade. Mas ele entende que, apesar de a ciência ser mais que um cientista (ser um contexto), o cientista e a narrativa do cientista são mais interessantes e acabam, consequentemente, por ganhar destaque nas narrativas da ciência.

A partir de narrativas sobre astronomia nas revistas Ciência Hoje, Ciência Hoje das Crianças e Superinteressante, avaliamos na sequência como o caráter educativo para públicos infanto-juvenis aparece nas três publicações.

\section{Tessitura histórica e conceitual da astronomia}

Quando traçamos a história da astronomia, ponto crucial e norteador das questões relevantes acerca das motivações e observações primeiras do céu, a investigação do nosso lugar na disposição do universo aponta, primordialmente, para os estudos do Sistema Solar. Na edição de abril de 2009, a Ciência Hoje aborda tais questões no texto "O Sistema Solar e seus corpos extraordinários" e deixa claro tal entendimento a respeito do nosso sistema planetário para a história da astronomia.

Mercúrio, Vênus, Marte, Júpiter e Saturno foram os primeiros corpos denominados planetas. A Terra só entrou na lista no início do século 17, com a aceitação do heliocentrismo, e Urano e Netuno foram descobertos anos de- 
pois, a partir de novos instrumentos de observação e teorias (Lazzaro, 2009, Ciência Hoje). Com tal explicação, a narrativa constrói a perspectiva histórica da astronomia, associada à noção de avanço científico e tecnológico. Mas o foco do artigo se insere na história recente, relacionada à descoberta de Plutão, em 1930, seguida dos objetos transnetunianos, em 1992, e toda a discussão subsequente a respeito das categorizações de corpos celestiais.

Esse pode ser considerado o melhor exemplo da dificuldade em separar de forma inequívoca as populações no Sistema Solar. Plutão foi descoberto após anos de procura pelo 'planeta X', que deveria ser responsável pelas discrepâncias que continuavam a existir na posição prevista de Urano, mesmo após a descoberta de Netuno (em tempo: hoje, sabemos que essas discrepâncias vinham da massa incorreta adotada para Urano). (Lazzaro, 2009, Ciência Hoje, p. 42)

A expectativa e busca pelo planeta se insere dentro da perspectiva constituinte de uma teoria segundo observado por Hawking (2006), um modelo capaz de fazer previsões; e dentro da noção de ciência moderna (Santos, 1989), sendo a empiria subsequente às previsões matemáticas e teorias produzidas. É interessante notar como a não concordância de Plutão com as previsões dos astrônomos à época de sua descoberta apontava então para falhas em tal modelo - que seriam compreendidas anos depois, como explica a autora e, ainda assim, este foi classificado como planeta até 2006, além de alegada razão às perturbações na órbita de Urano. Ao chamar a atenção para todas essas questões e não questionar tal compreensão anterior do corpo celeste, a narrativa da Ciência Hoje atenta para a mutabilidade da ciência, como algo inerente e natural ao processo:

Mesmo assim, era o único corpo descoberto naquela região do Sistema Solar, daí sua inquestionável classificação como planeta naquele momento. E, como a ciência evolui juntamente com o desenvolvimento tecnológico, também pode mudar a forma de classificar os objetos em classes que representem da melhor forma as características comuns a eles. (Lazzaro, 2009, Ciência Hoje, p. 42)

A astronomia é narrada, assim, como uma ciência sendo construída e construída coletivamente. O que caracterizaria uma determinada categoria de objetos é definido em conjunto pelos astrônomos, organizados na União 
A faixa infanto-juvenil como público da ciência e a ciência que lhes é proposta

Astronômica Internacional. O texto apresenta as recentes reuniões que deram origem à determinação das três classes de objetos no Sistema Solar (planetas, planetas anões e pequenos corpos), incutindo certa unidade aos estudos desses corpos, além de chamar a atenção para o aspecto humano - as escolhas e o olhar dos profissionais, em rede - na metodologia convocada às pesquisas.

Historicamente, essa perspectiva coletiva e transitória das teorias astronômicas se mostra bem resolvida nas três revistas. É comum às construções textuais - pelo menos dos textos de cunho didático - o desenho histórico dos sujeitos narrativos, a contextualização do lugar que ocupam dentro de subconjuntos das narrativas da astronomia e que se inserem, em outra instância, no amplo conjunto da ciência, de forma geral.

$\mathrm{Na} \mathrm{CH}$ das Crianças narra-se que "Houve uma época em que se pensava que o Sol girava ao redor da Terra" (Trevisan, 2009, p. 7); na Superinteressante, que "Os astrônomos, para onde quer que olhassem, só viam matéria. A antimatéria havia sido quase totalmente jogada para escanteio" (Nogueira, 2009, p. 80), e hoje a antimatéria ocupa posição de destaque em grandes e caras pesquisas ao redor do mundo; na Ciência Hoje, que "Forjada a partir da analogia com fenômenos magnéticos observados da Terra, a física celeste kepleriana reflete a dissolução da fronteira que na Antiguidade e na Idade Média separava a Terra e o céu como regiões essencialmente distintas" (Itokazu, 2009, p. 74).

O último exemplo é parte do texto "O nascimento de uma nova física celeste", voltado à memória do astrônomo Johannes Kepler, e compreende bom lugar de reflexão ao que aqui buscamos representar, sobre as narrativas históricas presentes nos textos. Kepler é apresentado como personagem revolucionário, inserido em um contexto científico que se dividia em três sistemas de mundo rivais, nenhum realmente apoiado pelo astrônomo, e nenhum realmente passível de comprovação observacional - ao menos não em sua totalidade.

Partindo da crítica ao modelo ptolomaico e da adoção de princípios e observações produzidos por Copérnico e Tycho Brahe, Kepler buscava encontrar e entender as posições e o movimento dos astros no céu, de tal forma que teria sido pioneiro na incursão da física aos estudos astronômicos.

A força solar, introduzida como explicação causal para o movimento dos planetas, é algo revolucionário à época de Kepler. Isso fica patente 
na crítica que lhe foi feita por seu professor de astronomia na Universidade de Tübingen, Michel Maestlin (1550-1631), para quem "questões astronômicas deveriam ser tratadas astronomicamente, por meio de hipóteses astronômicas, e não por causas e hipóteses físicas". (Itokazu, 2009, Ciência Hoje, p. 73)

O professor de Kepler é convocado à narrativa como representante de uma corrente teórica, apesar de vigente, contrária às ideias do astrônomo, obstáculo vivenciado e superado por este no correr da história - creditando a Kepler um caráter heroico. Superada se torna também essa ideia de astronomia, a da perfeição, dissociada da física e da Terra. "Kepler transforma o sistema de Copérnico em um heliocentrismo físico. O Sol ocupa posição central no céu e, além de iluminar o mundo, é responsável pelo movimento dos planetas" (Itokazu, 2009, p. 74). E, eventualmente, Kepler também seria ultrapassado, com sua física "fadada a ser substituída pela mecânica celeste de Isaac Newton" (p. 75).

No artigo "O ruído do Universo" conta-se a história da radiação cósmica de fundo em micro-ondas (RCFM) na evolução do universo e dentro dos estudos astrofísicos. Descrita como uma das mais poderosas ferramentas de pesquisa da cosmologia, o ruído faz parte da história recente das observações astronômicas, desde a sua descoberta acidental, em 1931, com a detecção de ondas de rádio provenientes do espaço pelo engenheiro Karl Jansky. A partir desse ponto, diversos cientistas e instituições tomam postos de personagens com participações cronologicamente dispostas na narrativa, dentro de um tradicional modelo de contar histórias.

A abertura do texto, para contextualizar a RCFM, se dá com a clássica estrutura de "era uma vez...": "De seu início, supostamente em um estado de grande densidade e alta temperatura, o universo evoluiu constantemente, se expandindo" (Villela Neto, 2009, p. 29). Insere então uma explicação atual do que se considera ser a radiação. Depois, e pela maior parte da narrativa, traça uma linha temporal com os eventos científicos que a envolveram - cada nova descoberta, as dificuldades com a empiria, problemas tecnológicos, teóricos e de aceitação na comunidade científica:

Uma grande preocupação tomou conta da comunidade científica. Tentativas de se medir o espectro da RCFM foram feitas para verificar se ele realmente era consistente com o previsto pela lei que rege o compor- 
A faixa infanto-juvenil como público da ciência e a ciência que lhes é proposta

tamento de um corpo negro (...) no entanto, não definiram claramente a situação. (Villela Neto, 2009, p. 31)

Por fim, o texto não apresenta caráter conclusivo, indicando as aberturas, novos problemas, "desafios" e perspectivas no estudo da radiação. Apesar de elementos que apontam para uma perspectiva da ciência fechada (como o subtítulo "Prova definitiva", onde se dispõem observações empíricas da RCFM como de origem cosmológica), de modo geral, a narrativa envolve a abertura de uma caixa-preta. Obviamente da perspectiva de um leigo, já que não passa por aspectos realmente técnicos, mas apresenta a evolução da temática, com os percalços produtivos, as dúvidas e a estrutura em rede da comunidade científica. Nota-se que na Ciência Hoje a maioria dos textos segue esse padrão, com narrativas que ganham mais espaço (número de páginas) para serem desenvolvidas e consequentemente tornam-se mais aprofundadas, revelando mais aspectos da construção da astronomia.

$\mathrm{Na}$ revista Superinteressante o caráter dúbio ciência pronta/ciência em construção se acentua, particularmente entre as temáticas brevemente discutidas nas notas, que ocupam entre meia e uma página da revista. Apesar de pontos teóricos e observacionais historicamente estáveis - portanto mais consolidados - serem pouco ou nada discutidos, reconhecemos o esforço narrativo em apresentar múltiplas visões e as incertezas relativas aos temas abordados, mesmo com a pouca profundidade dos textos, através das polêmicas existentes no meio científico. Essa característica fica mais evidente nas narrativas referentes a novas descobertas e atualidades. A revista dá muito espaço às novidades no meio científico, mas o presente parece ser também associado à ideia de construção e, portanto, ainda estar à prova.

Entrando na faixa etária infantil, a $\mathrm{CH}$ das Crianças tende, na balança entre construção e conclusão, a uma ideia de ciência pronta. Pensamos que tal perspectiva se ligue a dois elementos: o primeiro associado à linha editorial da publicação, cujos textos buscam tratar de temáticas não atuais, frias, e consequentemente mais estáveis entre os pares científicos; segundo, à maior dimensão pedagogizante da revista, que pode caracterizar narrativas menos contestadoras da ciência, mais assertivas sobre o seu lugar e consequência da noção de que ensinamos aquilo que sabemos.

Inclusive, termos como "sabemos", "conhecemos" e "vemos", além de falas direcionadas ao leitor ("Você sabia que..."; "já pensou que...") são recor- 
rentes nos textos ao tratar da astronomia: "Já sabemos que o movimento ao redor do Sol leva um ano para se completar. Sabemos, também, que enquanto gira em torno do astro-rei, a Terra vai dando voltas em torno do seu próprio eixo" (Trevisan, 2009, CH das Crianças, p. 8); "Você, certamente, já reparou que a Lua muda de aspecto no céu" (Guedes, 2009, p. 18); "Você já pensou que a cada aniversário a Terra completa uma viagem ao redor do Sol?" (2009, CH das Crianças, p.19); "Talvez você não saiba, mas os telescópios concentram a luz coletada por seus grandes espelhos (...)" (Castilho, 2009, CH das Crianças, p. 12).

Nesse espaço de explicação do mundo, as caixas-pretas são dadas e raramente abertas. Na resposta à pergunta "Por que o Sol vai morrer", na edição de julho de 2009 da revista, a astronomia é fechada e conclusiva. A narração estipula que o Sol é uma estrela, como qualquer outra, originada de poeira estelar e fadada ao fim. A história do Sol é assim contada cronologicamente: como se deu seu nascimento, sua evolução e qual será seu futuro. É uma narrativa tradicional, com início, meio e fim, sem espaços vazios ou disposição de dúvidas. A única questão deixada em aberto se refere ao que a morte do Sol significaria para a humanidade, algo ainda imprevisível: "Será o fim? Quem sabe? (...) é de se esperar que, com sua sabedoria, (a humanidade) seja capaz de descobrir e viajar para outros mundos e preservar nossa civilização" (Prado, 2009, p. 17).

Apesar de lidar com fatos fechados, parece ser interessante à $\mathrm{CH}$ das $\mathrm{Cri}$ anças uma interação mais aberta do leitor com a narrativa, a partir de um engajamento imaginativo lúdico que coloca a criança na posição de refletir e produzir as próprias conclusões a partir de observações próprias. É uma forma de inserir narrativamente a metodologia, o processo de construção da astronomia. E, assim, revela-se aquilo que é importante para o estudo dos astros, como a observação, os mecanismos, os instrumentos e a matemática.

\section{Referências bibliográficas}

Castelfranchi, Y. et al. (2008). O cientista é um bruxo? Talvez não: ciência e cientistas no olhar das crianças. In L. Massarani (org.) Ciência e criança: a divulgação científica para o público infanto-juvenil, (pp. 14-19). Rio de Janeiro: Museu da Vida / Casa Oswaldo Cruz / Fiocruz. 
A faixa infanto-juvenil como público da ciência e a ciência que lhes é proposta

Durant, J. (2005). O que é alfabetização científica?. In L. Massarani, et al (org.) Terra incógnita: a interface entre ciência e público. Rio de Janeiro: Vieira \& Lent, Casa da Ciência: FIOCRUZ.

Hawking, S. (2005). Os gênios da ciência: sobre o ombro de gigantes. Tradução de Marco Moriconi. Rio de Janeiro: Elsevier.

Latour, B. (2000). Ciência em ação: como seguir cientistas e engenheiros sociedade afora. $2^{\mathrm{a}}$.ed. São Paulo: Editora UNESP.

Miller, S. (2005). Os cientistas e a compreensão pública da ciência. In L. Massarani, et al (org.) Terra incógnita: a interface entre ciência e público. Rio de Janeiro: Vieira \& Lent: UFRJ, Casa da Ciência: FIOCRUZ.

Santos, B. (1989). Introdução a uma ciência pós-moderna. Rio de Janeiro: Graal.

\section{Referências das revistas}

Castilho, B. (2009). Você sabia que o Brasil tem telescópios de última geração fora do próprio território?. Ciência Hoje das Crianças, julho, 203: 12. Rio de Janeiro.

Guedes, L. (2009). Pintando a Lua. Ciência Hoje das Crianças, julho, 203: 18. Rio de Janeiro.

Itokazu, A. (2009). O nascimento de uma nova física celeste. Ciência Hoje, abril, 258: 73-75. Rio de Janeiro.

Lazzaro, D. (2009). O sistema Solar e seus corpos extraordinários. Ciência Hoje, abril, 258: 40-45. Rio de Janeiro.

Nogueira, J.S. (2009). Antimatéria. Superinteressante, janeiro, 261: 78-81. São Paulo.

Nogueira, J.S. (2009) Por dentro do Sistema Solar. Ciência Hoje das Crianças, julho, 203: 26-27. Rio de Janeiro.

Prado, L. (2009). Por que o Sol vai morrer?. Ciência Hoje das Crianças, julho, 203: 17. Rio de Janeiro.

Russomano, T. \& Beuermann, B. (2009). Como se tornar um astronauta. Ciência Hoje das Crianças, julho, 203: 10-11. Rio de Janeiro.

Santos, M.R. (2009). A bactéria que veio do céu. Superinteressante, julho, 267: 41. São Paulo. 
Trevisan, R. (2009). Astronomia no dia-a-dia. Ciência Hoje das Crianças, julho, 203: 6-9. Rio de Janeiro.

Trevisan, R. (2009). Vida na Terra pode ter vindo do espaço. Superinteressante, outubro, 270: 22. São Paulo.

Villela Neto, T. (2009). O ruído do universo. Ciência Hoje, dezembro, 266: 28-33. Rio de Janeiro. 


\title{
Exposições de Dinossauros em Portugal Comunicar Paleontologia, Métodos e Problemáticas
}

\author{
Simão Mateus \\ Museu da Lourinhã \\ E-mail: simaomateus@rocketmail.com
}

\begin{abstract}
Resumo
Portugal tem diversos museus com exposições de paleontologia que abordam a temática dos dinossauros, alguns já expondo esqueletos completos em forma de vida nas suas colecções permanentes. $\mathrm{O}$ aparecimento deste género de exposições desde os anos oitenta tem acompanhado a crescente procura por este produto, mas será que tem acompanhado as expectativas? Como é que o público percepciona os dinossauros? Como fonte de deslumbramento e entretenimento do público in-

fantil? Como colecção de esqueletos de um museu de história natural? Como resultado de uma investigação científica complexa? Pretende-se fazer o levantamento de algumas exposições com dinossauros de Portugal, caracterizar a tipologia de discurso expositivo, a metodologia aplicada e as suas debilidades. Os diversos museus, ou congéneres equivalentes, foram visitados ao longo dos últimos anos, e feito uma análise às suas exposições.
\end{abstract}

Palavras Chave: Exposição de Dinossauros; Paleontologia; Museus Portugueses; Fósseis; Réplicas.

\begin{abstract}
Portugal has several museums with paleontology exhibitions that showcase dinosaurs, some with complete skeletons in lifelike positions in their permanent collections. Since the 1980s, this type of exhibition has met the rise in public demand, but has it also met its expectations? How does the public perceive dinosaurs? As a source of wonder and entertainment for children? As part of the skeleton col-

lection from a natural history museum? As the result of complex scientific research? This article will present a survey of some of the dinosaur exhibitions in Portugal, characterizing the type of exhibition, the metholodogy that was applied and it's frailties. Various museums, or similar entities, were visited over the past few years and their exhibits were analyzed.
\end{abstract}


Key-words: Dinosaurs exhibitions; Paleontology; Portuguese Museums; Fossils;

Casts.

\section{Introdução}

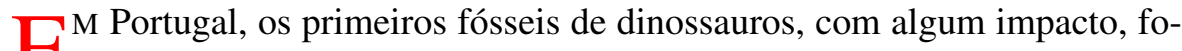

C ram expostos no início da segunda metade do século XX, no Museu Geológico e Mineiro de Lisboa, nomeadamente os grandes saurópodes denominados por Lapparent e Zbyszewski (1957) como o Brachiosaurus atalaiensis ou o Apatosaurus alenquerensis, actualmente os géneros Lusotitan e Lourinhasaurus respectivamente.

Nos anos oitenta, com o crescimento do número de museus em Portugal, aqueles em regiões fossilíferas, nomeadamente Mesozóicas, começaram a expor fósseis de grandes vertebrados. O uso dos fósseis em exposição vai desde a curiosidade geológica, herdado dos gabinetes de curiosidades, ao afirmar da relevância histórica de um dado concelho (Mateus, 2014). Os museus da zona Oeste não passaram ao lado desta tendência e, mais ou menos cientificamente, começaram a expor o seu património paleontológico. Hoje já existem diversos museus com exposições de dinossauros, alguns com esqueletos completos em forma de vida nas suas colecções permanentes.

Se, nos anos oitenta, a única forma de observar um esqueleto de dinossauro montado em forma de vida era viajando até aos museus de história natural internacionais, como o de Paris, Londres ou Berlim, com o advento das exposições temáticas, do início dos anos 90, passou a ser possível fazer a sua visualização também em Portugal, pelo menos temporariamente. Só em 2007 é que Portugal passou a contar com esqueletos completos nas suas exposições permanentes, nomeadamente os dinossauros portugueses, Lourinhanosaurus antunesi e o Miragaia longicollum no Museu da Lourinhã.

Este museu é, aliás, um caso particular. Foi inaugurado em 1984, e encontrou nos dinossauros o seu carácter de unicidade, com salas de exposição inteiramente dedicadas a estes animais e outros répteis mesozóicos, e que levou a vila a ser conhecida como a Capital dos Dinossauros.

Mas será que este género de exposições serve o propósito da comunicação científica, a comunicação da paleontologia? 
Exposições de Dinossauros em Portugal: Comunicar Paleontologia, Métodos e Problemáticas

Os museus podem ter objectivos conflituosos: de investigação científica, educação do público, e entretenimento da população. Um tema que atraia as audiências é tão importante para entretenimento do público como para financiamento do museu. (Rieppel, 2012: 460).

No caso Português a maioria dos museus não desempenha um papel significativo no campo da investigação cienífica, existindo porém algumas excepções (Delicado, 2008: 69). A maioria dos museu portugueses tem mais preocupações com a educação do público, enquanto que as exposições temporárias com dinossauros servem principalmente de entretenimento, nomeadamente infantil.

\section{Dinossauros e os objectivos museológicos}

Shmuel Meiri (2004) expõe na sua tese The museology of dinosaurs: in search of the authentic museum dinosaur, a história da museologia de dinossauros e a problemática da autenticidade e papel educativo dos objectos expostos. No caso dos dinossauros, vai uma grande distância da exposição de investigação paleontológica, pura, passando pela exibição de esqueletos montados, até ao aparecimento de modelos flesh-out, i.e., com reconstituição das partes moles, como se estivessem vivos (Figura 1).

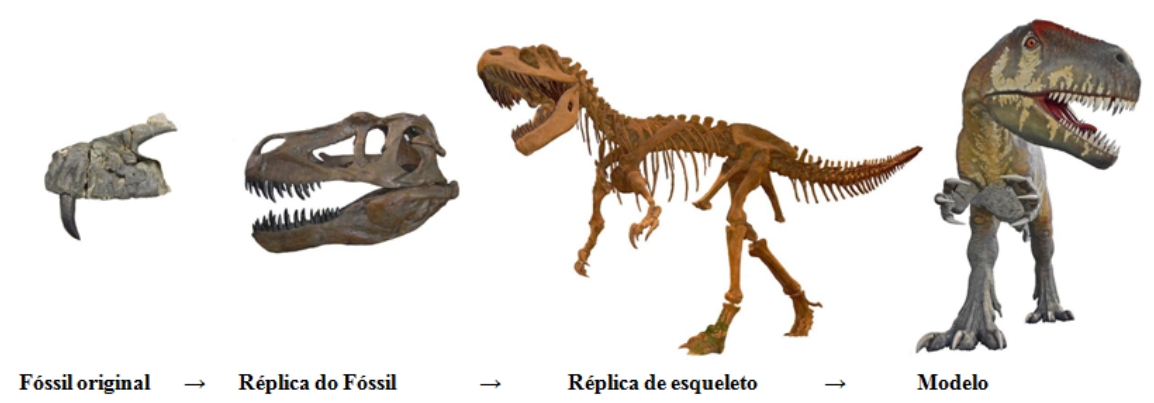

Figura 1 - Torvosaurus gurney, diversos aspectos (Fóssil ML1100; Réplica de crânio do Museu da Lourinhã; Esqueleto de Torvosaurus tanneri, do North American Museum of Ancient Life, fonte Wikimedia Commons; Modelo do Dinosaurier-park Münchehagen) 
Para a investigação científica dos paleontólogos praticamente só os fósseis contam, independentemente do grau de completude e estética inerente ao próprio fóssil. Mas frequentemente esse fóssil é de dificil interpretação para um leigo, ou seja, a maioria do público.

Já a presença de um esqueleto montado em forma de vida permite uma leitura quase universal. Os esqueletos em posição de vida têm uma legibilidade mais rápida e fácil que um esqueleto original e parcial, sendo as réplicas mais atractivas ao grande público (Mateus, 2009).

A montagem de um esqueleto passa por uma série de interpretações que, pretendendo ser o mais correctas possíveis, são, ainda assim, permeáveis a erros (Meiri, 2004).

A larga maioria dos dinossauros é descoberta com menos de metade do esqueleto. A parte em falta pode ser colmatada de diversas formas: i) por simetria bilateral (p.e.: com o membro direito reproduz-se o esquerdo); ii) com outros esqueletos de animais da mesma espécie (casos raros); iii) com as espécies mais próximas possíveis (sister clade); iv) por escultura interpretativa (p.e.: faltando vértebras, esculpem-se as falhas tendo em atenção a morfologia das vértebras adjacentes. Todos estes métodos visam o aumento interpretativo de um fóssil, mas elevam a possibilidade de erro inerente da interpretação. São estes a maioria dos objectos que o público observa em exposições com dinossauros.

Além da contemplação, a presença de réplicas de dinossauros numa exposição pode servir como elementos interpretativos de originais que disso necessitem, quer por questões de dimensão como por questões de facilitador de compreensão, ou servirem como cópias de segurança, divulgação e duplicação, marketing e produto financeiro (Mateus, 2009).

Quando se passa à reconstituição de um animal com partes moles, com "pele", a interpretação aumenta e, com ela, a margem de erro. O caso clássico de interpretação máxima é a cor atribuida aos animais, que é desconhecida e fica ao critério estético do paleoartista, não tendo qualquer critério científico. Este é o caso da maioria dos parques temáticos com dinossauros.

Assim vemos uma progressão que vai entre o científico e o lúdico e que acompanha a progressão que vai desde o fóssil ao modelo, a investigação ao entretenimento. (figura 2) 


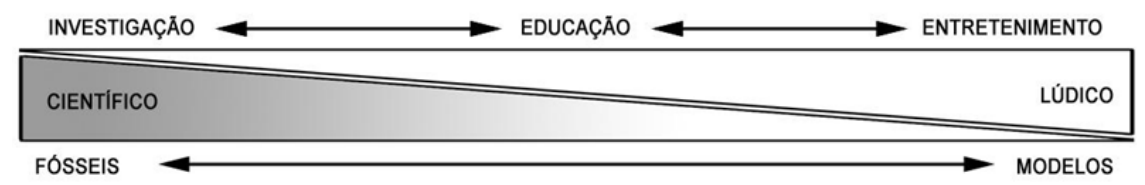

Figura 2 - Diagrama interpretativo de fósseis a modelos

Em certos aspectos esta progressão parece estar intimamente ligada à idade do público alvo, ou, pelo menos, à tipologia deste. Fósseis são procurados por público científico, investigadores e universitários. Esqueletos para um público mais generalista aberto às ciências naturais, e quando falamos de parques temáticos, quase sempre as actividades estão direccionadas para o público infantil. Quando se visita um parque temático de dinossauros, sem se levar crianças, existe frequentemente um sentimento de não pertença, de, enquanto adultos, sentirmo-nos deslocados. As atracções, interpretações, os espaços de descanso e mesmo os menus da cafetaria são viradas principalmente para as crianças. O exemplo mais próximo é o caso de Dinópolis, em Teruel, Espanha.

Esta orientação museográfica não tem que ser necessariamente dirigida ao público infantil, mas a realidade é que esses parques são geridos tendo em vista as famílias com filhos pequenos. A exposição visa a satisfação da criança, enquanto produtor de sentimento de aventura de "Parque Jurássico", e os adultos como produtor de sentimento de tempo de qualidade com as crianças mais do que como promotor de divulgação científica.

Por outro lado, é inegável o papel do entretenimento infantil como substancial fonte de financiamento para a gestão diária e manutenção dos parques e museus e que, indirectamente suportam parte da investigação científica.

\section{Exposições de Dinossauros em Portugal}

Portugal teve fósseis de dinossauros em exposição desde a segunda metade do século XX, nomeadamente no Museu Geológico e Mineiro, em Lisboa, resultantes das expedições das comissões geológicas. A exposição de 
esqueletos completos só se deu no final do século XX e sob a forma de exposições temporárias ${ }^{1}$.

A primeira exposição de dinossauros em Portugal, com grande impacto no público, ocorreu em 1992/1993 no Museu Nacional de História Natural e da Ciência (MUHNAC) com esqueletos completos e dinossauros robotizados. A exposição denominava-se "Dinossaurios Regressam a Lisboa" com uma afluência recorde de 350 mil visitantes (Leite, 2009: 33). No ano seguinte foi a vez da exposição "Dinossauros ao vivo" no Jardim Zoológico de Lisboa.

O sucesso das duas primeiras exposições temporárias, do Museu de História Natural e do Jardim Zoológico, ambas em Lisboa, com esqueletos completos e dinossauros robotizados, mostrou a apetência que o público tinha por esta temática. Público esse que tinha, e tem, nas crianças o seu motor.

Estas exposições têm como aliado o filme de Steven Spielberg, Jurassic Park, que em 1993 vem fomentar a procura dos dinossauros num fenómeno que ficou conhecido por "dinomania", numa explosão de popularidade destes animais (Meiri, 2004; Mitchell, 1998).

Já no século XXI começam a ser mais comuns as exposições temáticas com esqueletos completos e nos últimos anos aparecem à razão de uma por ano. A descoberta da característica lucrativa dos dinossauros, que começam também a ter preços mais em conta, nem sempre gera exposições de qualidade científica. Um exemplo negativo foi a série de do "Mundo dos dinossauros" que começa em 2011 na cordoaria nacional, com um rigor científico duvidoso, havendo dioramas com encontros de animais de Eras diferentes, pterossauros montados de braços ao contrário e posteres informativos que surgiam de más traduções de livros, com palavras da mesma frase em três línguas e o poster a acabar em rodapé "como se vê na próxima página". As megas exposições de dinossauros começam a ser utilizadas principalmente como máquinas de fazer dinheiro.

Um caso de comunicação de paleontologia diferente foi a do espetáculo Walking With Dinosaurs, em Lisboa, no Pavilhão Atlantico, 14 e 16 de Maio de 2010. O espetáculo continha robôs manipulados por operadores que interagiam com um actor (Paulo Matos) que desempenhava o papel de paleontólogo.

1. Ver em anexo a cronologia das principais exposições temáticas de dinossauros em Portugal. 
Exposições de Dinossauros em Portugal: Comunicar Paleontologia, Métodos e Problemáticas

Neste espetáculo não existem fósseis, réplicas ou modelos para se visitar, e por isso não pode ser considerado uma exposição museológica.

\section{Comunicar paleontologia e o léxico científico: O exemplo de "Aves"}

Assim como o uso de fósseis, sem alterações interpretativas, o uso de modelos tem uma progressão do mais científico para o mais lúdico, a terminologia usada no acompanhamento do discurso expositivo também possui idêntica progressão, indo da mais científica e menos perceptível à maioria do público, para a mais popular e compreensível, mas mais aberta a erros (figura 3). Quanto mais público se pretende alcançar menos conceitos se pode exigir. Ainda por cima quando o público é constituido por crianças a nível do primeiro ciclo escolar (Mateus et al., 2014).

Conceitos como eras e períodos, género e espécie, holótipo e autapomorfia, fundamentais na linguagem palontológica e pertencem ao léxico da literatura científica, são expressões vagas, ou mesmo inexistentes, para o público leigo.

Os paleontólogos necessitam de usar critérios taxonómicos como autoridade científica para dar significado a nomes e um dos casos clássicos é a propriedade da palavra "aves". Qualquer pessoa consegue perceber o que é uma ave e esta palavra, e o seu conceito, é muito anterior à de dinossauros.

No entanto, paleontologicamente o significado de ave não é assim tão claro. A comunidade científica teve dificuldade em definir apartir do momento em que um dinossauro era considerado uma ave: i) tinha penas; ii) voava; iii) os descendentes do Archaeopteryx; ou, iv) eram os descendentes vivos que resultam de iii e são somente as aves actuais (Gauthier e Queiroz, 2001: 8).

Independentemente do que são, a compreensão do público de uma exposição do que é uma ave dificilmente coincidirá com a do paleontólogo.

A equipa museográfica não deve presumir o conhecimento de conceitos complexos por parte do público e os cientistas devem acautelar a arrogância de achar que o seu léxico é o detentor de toda a verdade científica e a humildade de ceder em precisão científica alcançando porém maior compreensibilidade. 


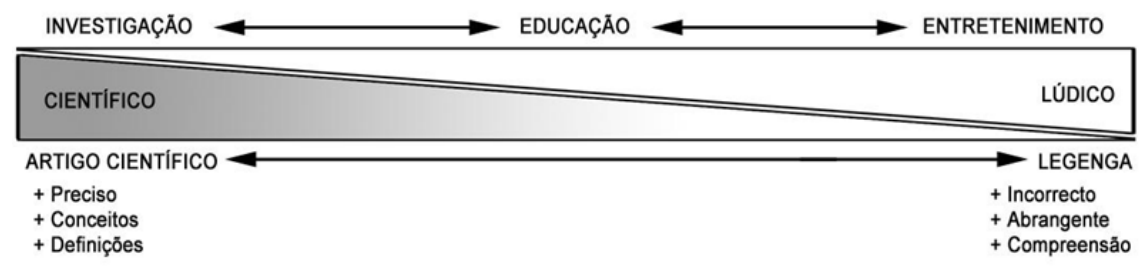

Figura 3 - Diagrama interpretativo do léxico dos artigos científicos às legendas museológicas

\section{Dilema cognitivo}

As crianças em idade pré-escolar começam a aprender o nome dos dinossauros, com alguma facilidade. Sabem o nome dos dinossauros mas ainda não conseguem relacioná-los com aspectos mais abstractos como eras e períodos, taxonomia e evolução, só conseguindo apreender os conceitos abstratos como o que é um dinossauro ou o tempo geológico mais para o final do ensino básico (Barba, 1995). Não obstante, existe uma procura por parte dos tutores de introduzir estes conceitos complexos às crianças mais pequenas. A maioria dos museus e exposições de dinossauros não estão preparados para a transmissão dessa informação, nem através dos textos nem do discurso expositivo. A fim de colmatar esta stuação, em alguns casos recorrem-se aos serviços educativos e às visitas guiadas. No caso da comunicação da paleontologia pode não ser simples. As crianças têm falta de capacidade de concentração para ter uma explicação muito longa e facilmente perdem o interesse.

Um caso particular ilustra a problemática da comunicação da paleontologia: Um casal com uma criança de cinco anos pede uma visita guiada. $\mathrm{O}$ guia, mestre em paleontologia, tenta fazer uma introdução básica ao tema sendo interrompido pelos pais com o pedido: «Não fale para nós (adultos) fale para ele (criança)!». A explicação dos conceitos básicos da paleontologia fica assim limitada à capacidade de aquisição de conhecimentos de uma criança de cinco anos, que regra geral sabem o nome de alguns dinossauros, e associam herbívoros como "bons", e carnívoros como "maus". Quais os dinossauros que, por exemplo, existiam no Jurássico e em Portugal é praticamente impossível de passar. 
A afirmação de que uma criança "sabe tudo sobre dinossauros" porque sabe o nome de alguns dinossauros mais mediáticos, é semelhante a saber o nome dos cromos de futebol, mas não se saber de que clube são, em que posição jogam, as regras, ou sequer saberem jogar futebol.

Mas a dificuldade de comunicar ciência a crianças não quer dizer que seja impossível. Um caso de sucesso foram os desenhos animados do Comboio dos Dinossauros ${ }^{2}$, onde uma família de Pteranodons adopta um T.rex. Nestes desenhos animados os jovens dinossauros andam num comboio de linha da era Mesozóica atravessando o túnel do tempo que para em três estações: o Triásico, o Jurássico e o Cretácico. Nas aventuras, estas personagens, que mimetizam crianças, vão conhecendo outros dinossauros e répteis mesozóicos aprendendo particularidades de cada animal e de cada período. No final de cada episódio um paleontólogo, Dr. Scott ${ }^{3}$, ainda responde a uma questão relacionada com o abordado anteriormente.

\section{Conclusão}

A comunicação da ciência para o público leigo, nomeadamente a paleontologia dos dinossauros, é um compromisso entre o fóssil puro original e a espetacularidade do dinossauro completo. E é um compromisso mais difícil de alcançar quando se tem em conta o público que faz mover os visitantes às exposições de dinossauros: crianças do primeiro ciclo. A equipa museográfica tem de saber gerir a precisão científica e a compreensão expositiva. Cabe ao museógrafo conseguir resumir que conceitos o paleontólogo acha imprescindível que estejam presentes. Como os transmitir da forma mais compreensível, e de preferência lúdica, sem perder precisão. Para isso o papel dos diversos agentes que constroem a exposição deve ser humilde nas competências dos seus pares, mas especializado nas suas próprias competências. Não cabe ao museógrafo saber o que transmitir assim como não cabe ao paleontólogo impor como transmitir. Cada vez mais, no caso da paleontologia assim como noutras ciências, deve almejar-se a especialização da museografia, e não

2. Dinosaur Train, é uma produção liderada pela The Jim Henson Company, dirigida por Craig Bartlett, de 2009, Americana, Canadiana e de Singapura.

3. Scott Sampson, é Canadiano douturado em Zoologia pela Universidade de Toronto, actualmente ocupando o cargo de "Vice President of Research \& Collections and Chief Curator" do Museu da Ciência e da Natureza de Denver. 
ocorrer, o que tantas vezes acontece, em que o cientista é especialista e consequentemente o discurso falha porque o responsável pela comunicação não o era.

\section{Bibliografia}

Barba, R.H. (1995). Children's Tacit and Explicit Understandings of Dinosaurs. Annual Meeting of the National Association of Research in Science Teaching, April: 2-14. San José. California.

Delicado, A. (2008). Produção e reprodução da ciência nos museus portugueses. Análise Social, XLIII(1): 55-77.

Gauthier, J. \& Queiroz, K. (2001). Feathered dinosaurs, flying dinosaurs, crow dinosaurs, and the name "Aves". In J. Gauthier \& L.F. Gall (eds.) New Perspectives on the Origin and Early Evolution of Birds: Proceedings of the International Symposium in Honor of John H. Ostrom. New Haven: Peabody Mus. Nat. Hist., Yale Univ.

Lapparent, A.F. \& Zbyszewski, G. (1957). Les Dinosauriens du Portugal. Memórias, Serv. Geol. Port., 2 (Nova série).

Leite, J. (2009). Contributo do Museu Nacional de História Natural para a divulçação do património Geológico: Caracterização do Público do Departamento de Mineralogia e Geologia. Tese de Mestrado pela Universidade do Minho.

Mateus, S. (2009). Qual o papel das réplicas museológicas?. Journal of Paleontological Techniques, Maio (6): 20-21. ISSN: 1646-5806.

Mateus, S. (2014). Fundamentos para uma exposição hipotética do Jurássico Superior da Lourinhã. Tese de Mestrado em Paleontologia, pela FCTUNL e UE.

Mateus, S.; Mateus, M. \& Faria, M.L. (2014). Público do Museu da Lourinhã, A procura dos dinossauros como paleopatrimónio. Atas / Proceedings I Encontro Luso-Brasileiro de Património Geomorfológico e Geoconservação: 82-88. ISBN: 978-989-96462-5-4.

Meiri, S. (2004). The Museology of Dinosaurs: in Search of the Authentic Museum Dinosaur. Tese de Doutoramento em Filosofia, pela University of Leicester. 
Exposições de Dinossauros em Portugal: Comunicar Paleontologia, Métodos e Problemáticas

Mitchell, W.J.T. (1998). The Last Dinosaur Book. The University of Chicago Press, Chicago.

Rieppel, L. (2012). Bring Dinosaurs Back to Life, Exhibiting Prehistory at the American Museum of Natural History. Isis, 103:460-490.

\section{Anexo}

\section{Cronologia das Exposições Temáticas de Dinossauros em Portugal}

1992 - "Dinossaurios Regressam a Lisboa" no Museu Nacional de História Natural e da Ciência em Lisboa (MUHNAC)

1994 - "Dinossauros ao vivo" no Jardim Zoológico de Lisboa.

2003 - Dinossauros da Mongólia, no Pavilhão Rosa Mota, no Porto.

2004 - Dinossauros de Gobi, Mongólia, na Torre Vasco da Gama, Lisboa.

2005 - "Plumas em Dinossáurios - Afinal nem Todos se Extinguiram" MUHNAC.

2010 - “Allosaurus: um dinossáurio, dois continentes?" - Exposição temporária de longa duração no MUHNAC.

2011/2012 - "O Mundo dos Dinossauros" em Lisboa na Cordoaria Nacional, em 2011, no Porto no Pavilhão Rosa Mota, em 2012, na Batalha na Exposalão, de 31 de Março a 3 de Junho de 2012, e em Portimão, no Parque de Feiras e Exposições, de 11 de Julho a 09 de Setembro de 2012.

2012/2013 - "T.rex: Quando as galinhas tinham dentes", no Pavilhão do Conhecimento, Lisboa.

2014 - "Planeta Dinossauro", no Pavilhão de Portugal, Lisboa. 
$\bigoplus$

$\bigoplus$

$\oplus$ 


\title{
A Comunicação nas ciências interdisciplinares: o compromisso de um discurso - o caso da área da Saúde
}

\author{
Anabela Félix Mateus \\ LabCom.IFP/Universidade da Beira Interior \& FCT \\ E-mail: anabela.mateus@netcabo.pt
}

\begin{abstract}
Resumo
A complexidade dos problemas modernos da sociedade e uma necessidade de inovação levam a considerar um processo de convergência entre diferentes áreas de investigação científica. Os desafios do tempo globalizado têm na interdisciplinaridade um de seus pilares. Algo é de salientar: distintas ciências, discursos próprios. O efeito sinérgico que resulta de uma complementaridade ativa das diversas ciências que se propõem a um mesmo objetivo só se obtém através da ação da comunicação, presente ao longo todo o processo. A área da saúde revela-se particularmente importante: apresenta um discurso particular, muitas vezes técnico, e tendo como referências absolutas as

onais, demonstrando-se praticamente fechado aos usuários que a ele recorrem. No presente artigo analisamos a eficácia da comunicação verbal utilizada na área da Saúde, voltada para seu público mais direto. Usamos análise do discurso de entrevistas informais diretas a responsáveis pela comunicação verbal na relação médico / paciente e análise de conteúdo de bulas de medicamentos, realizada por consumidores comuns. Esperamos contribuir para incentivar a reflexão consciente pelos atores envolvidos na codificação e transmissão de mensagens, a fim de se obter uma maior eficácia da comunicação num relacionamento de transparência em Saúde.
\end{abstract} simbologias e terminologias dos profissi-

Palavras-chave: Comunicação; informação; saúde; interdisciplinaridade.

\begin{abstract}
The complexity of the modern problems of the society and the necessity of innovation imply significantly a convergence process between different areas of

scientific research. The challenges of globalization have on interdisciplinarity one of its pillars. Something has to be highlighted: different sciences, dif-
\end{abstract}


ferent speeches. The synergistic effect, which results from an active complementarity of different sciences that have the same goal, can only be obtained through the communication action, present all throughout the process. The health area is especially important: it presents a particular discourse, often technical, and with absolute references the symbolics and the terminology of professionals, being virtually closed to users who recourse to it. In this article we analyze the effectiveness of verbal communication used in the health area, directed most closely to the public. We use discourse analysis of direct informal interviews by the person responsible for medical verbal communication / patient relationship and content analysis of inserts labeling drugs, done by ordinary consumers. We hope to contribute and encourage the conscious reflection by the actors involved in encoding and in the transmission of messages in order to obtain a greater effectiveness of communication and a relationship of transparency in Health.

Keywords: Communication; information; health; interdisciplinarity.

\section{A Comunicação nas Ciências da Saúde}

TNFORMAÇÃO e comunicação encontram-se na base de uma sociedade que se pretende saudável. Passa pela pesquisa; passa, como consequência, pela divulgação de novos saberes.

A questão da informação é levantada pela necessidade da existência de códigos comuns de quem informa e de quem necessita de ser informado:

A necessidade de estabelecer uma ancoragem entre a comunicação e a saúde vem merecendo a dedicação de profissionais destas duas áreas, principalmente desde que, a partir da segunda metade do século XX, um novo paradigma propôs um deslocamento da doença para a saúde, visando sua promoção e prevenção, com a utilização de diversas ações comunicativas como ferramenta indispensável para atingir este objetivo (Bertol, p. 258)

Por outro lado, a complexidade dos problemas da sociedade moderna e a necessidade de inovação, levam a considerar um processo de convergência entre as diversas áreas de pesquisa científica.

Os desafios do tempo globalizado assentam hoje na inevitável interdisciplinaridade. Interdisciplinaridade que, por sua vez, sem o fator dinâmico 
A Comunicação nas ciências interdisciplinares: o compromisso de um discurso - o caso da área da Saúde

da Comunicação e a fundamental responsabilidade da interligação entre os distintos campos da ciência que lhe estão inerentes, não é passível de se concretizar.

Mas algo há a realçar: ciências distintas, discursos próprios. A necessidade de um esforço suplementar de cada uma das áreas, complementares, em ordem a uma comunicação eficaz e eficiente, impõem-se dentro de cada grupo, devido às características dos seus discursos técnicos e científicos, particulares a cada uma, na maior parte das vezes também difíceis de descodificar aos públicos a quem se dirigem. "Veja-se o exemplo da saúde pública, em que se tem de trabalhar com meio-ambiente, saúde, economia, participação social, comunicação, envolvimento da sociedade, epidemiologia, estatística, entre outras"(Professor Philippi Jr.) ${ }^{1}$. Tudo em simultâneo.

É nosso objetivo alertar para uma realidade não muito contemplada pelas Ciências da Saúde em Portugal, detentoras de linguagens e discursos muito próprios, herméticos e virados para si próprios, caraterizados por um particular tecnicismo, colocando num segundo plano de importância, muitas das vezes, os principais recetores das mensagens transmitidas: o público em geral.

Não duvidamos também que é do intercâmbio e da partilha de áreas distintas que se conseguem sinergias que levam a novos saberes. E como é de relembrar, o efeito sinérgico que resulta da complementaridade ativa das várias ciências que se propõem a um mesmo objetivo, só se obtém através da ação da Comunicação.

Há pois que estar atento, à grande necessidade cada vez mais presente ao longo de todo o processo no sentido de um esforço a ser feito pelos técnicos e especialistas, nomeadamente na tentativa de Informação ao grande público, os utentes, dos mais afetados com falta de informação pelo tecnicismo da linguagem registada e hermetismo dos discursos apresentados, e também em relação aos parceiros de distintas áreas, numa necessidade de partilha de informação e intercâmbio, também cada um com linguagens e discursos próprios, o que se traduz em barreiras muitas vezes difíceis de transpor.

1. "Ciência caminha para a interdisciplinaridade, dizem pesquisadores" $3^{\mathrm{a}}$ Reunião de Coordenadores de Programas de Pós-Graduação da Área Interdisciplinar (Recopi) Finatec, Brasília, 2008, on line. 


\title{
A pertinência dos conceitos e sua aplicação
}

\section{Interdisciplinaridade e sua oportunidade hoje}

O termo foi publicado pela primeira vez em 1937 pelo sociólogo Louis Wirtz que definia a interdisciplinaridade como a qualidade daquilo que é interdisciplinar, e a entendia por aquilo que se realiza com a cooperação de várias disciplinas.

O facto é que passado bem mais de um quarto de século o termo mantémse fiel a esse conceito: para que haja interdisciplinaridade é preciso que haja mais de uma disciplina e implica uma relação de troca entre elas de modo a cumprirem objetivos e obterem mais-valias que de uma forma isolada não conseguiriam alcançar.

Segundo Japiassu (1976, p.74, in Francischet):

\begin{abstract}
A interdisciplinaridade caracteriza-se pela intensidade das trocas entre os especialistas e pelo grau de interação real das disciplinas no interior de um mesmo projeto de pesquisa (e traduz-se como) (...) um método de pesquisa e de ensino suscetível de fazer com que duas ou mais disciplinas interajam entre si, esta interação podendo ir da simples comunicação das idéias até a integração mútua dos conceitos, da epistemologia, da terminologia, da metodologia, dos procedimentos, dos dados e da organização da pesquisa. (Japiassu, 1991, p.133, in Sommerman: 2006, p.30, cit por Staudt op. cit, p.17).
\end{abstract}

A importância da interdisciplinaridade assenta e deriva do desenvolvimento científico-técnico pelo que veio proporcionar o surgimento de numerosos ramos científicos. Nessa medida permite não só integrar novas abordagens na busca de um conhecimento cada vez mais aprofundado, como possibilita que o objeto de estudo seja abordado de uma forma integral e sob múltiplos enfoques metodológicos.

Assim pode ser encarada como uma abordagem metodológica que consiste na procura sistemática da integração das teorias, dos instrumentos e das fórmulas de ação científica de diferentes disciplinas, baseada numa conceção multidimensional dos fenómenos. É por isso que hoje em dia a tendência é geral, e independentemente da forma, todas as ciências recorrem à interdisciplinaridade para atuarem e se desenvolverem. 
A Comunicação nas ciências interdisciplinares: o compromisso de um discurso - o caso da área da Saúde

\section{Comunicação}

Precisamos saber do que falamos. Precisamos entender-nos.

Comunicar é isso. Utilizar um código que seja comum a todos os intervenientes de um mesmo grupo.

As perspetivas são muitas: desde a Sociologia, à Antropologia, passando pela Psicologia, ciências que se tangem, também com o ser humano enquanto interveniente direto e fundamental ao processo. Trata-se de importantes e significativos exemplos, mas tão só; noutra perspetiva, um campo habitualmente não muito referenciado ao tratar-se das Ciências da Comunicação: com objetos e meios distintos, mas objetivos idênticos, encontram-se as tecnologias traduzidas no meio da informática e afins; fundamental referir, a etimologia do termo Comunicação, Comunicar. A sua origem encontra-se no Latim 'communis', pôr em 'comum'.

Uma nota ainda, perante o teor do presente trabalho: a inegável relação implícita entre a Linguística e a Teoria da Comunicação: já Aristóteles defendia, que o homem é um ser social, e a linguística é-lhe fundamental....

Na sequência de tudo o que foi dito, ninguém poderia afirmar melhor do que Marques de Melo: “(...) ao analisar o fenômeno comunicativo, cada ciência e corrente filosófica utiliza a sua própria perspectiva, a sua própria terminologia, os seus conceitos específicos. (1975 p.14)".

\section{Informação}

Existem muitas e variadas definições de informação, bastante complexas.

Muito simplesmente pode-se dizer que a informação é um conjunto organizado de dados que constitui uma mensagem sobre um fenómeno ou evento com vista a permitir resolver problemas e tomar decisões, tendo em conta que o seu uso racional é a base do conhecimento; noutra perspetiva a informação apresenta-se como um fenómeno que confere significado ou sentido às coisas, uma vez que através de códigos e de conjuntos de dados, forma os modelos do pensamento humano.

Em termos muito sintéticos Zorrinho (1995) definiu-a como "um instrumento de compreensão do mundo e da acção sobre ele". 


\section{Comunicação em saúde}

Comunicação em saúde, uma área específica da Comunicação, diz respeito ao estudo e utilização de estratégias de comunicação para informar e para influenciar as decisões dos indivíduos e das comunidades no sentido de promoverem a sua saúde.

Esta a é uma definição, que vai de encontro às nossas convicções na linha do que propõe Teixeira (p. 615. s/d).

\section{Os Métodos de Trabalho}

Para a realização do presente trabalho recorreu-se a uma análise de teor puramente qualitativo, a Análise do Discurso, indiferentemente aplicada a entrevistas orais e documentos originalmente escritos, nomeadamente as bulas dos medicamentos.

Segundo Caregnato; Mutt (2006, p.681) com a Análise do Discurso, a língua é considerada opaca e heterogênea, logo torna-a passível de equívocos, falhas, bloqueios de comunicação. O sentido da palavra, do discurso, não é objetivo mas subjetivo. Inclusivamente pelas posições distintas de conhecimento entre emissor e recetor - especialista e utente.

Para Pêcheux, (in Caregnato; Mutti, idem, ibidem) "todo dizer é ideologicamente marcado". No presente contexto a linguagem utilizada pelos especialistas da área da medicina e, particularmente grande parte das bulas que acompanham os medicamentos e pretendem informar sobre o produto em causa, encontrar-se-ão particularmente marcadas pelo tecnicismo que acompanha a área da saúde. Uma linguagem hermética e adaptada ao coletivo de um campo científico, representante de uma classe de investigadores e especialistas.

Na generalidade, os cientistas não são eficientes ou eficazes na explanação do seu trabalho para uma vasta audiência, sobretudo porque se encontram centrados e focados na própria pesquisa, e não estão particularmente bem acostumados a comunicar esse conhecimento ao público em geral. Eles tendem a usar palavreado, desnecessariamente detalhado ou demasiado técnico. Caiem em jargão incompreensível para qualquer um que esteja fora do seu campo de investigação (Hartz; Chappel in Mateus:2010, p.13) 
A Comunicação nas ciências interdisciplinares: o compromisso de um discurso - o caso da área da Saúde

Se embora, por uma questão de isenção científica na maior parte das investigações se decida por um afastamento entre o conhecimento empírico dos autores e a investigação realizada, as experiências vividas pela autora no presente campo é de tal forma rica, que se demonstra impossível não a incluir na presente análise.

É de recordar que este tipo de análise não implica uma análise exaustiva do documento escrito ou entrevista em causa. Qualquer elemento aí existente pode ser estudado enquanto marca linguística, ou "marca de discurso", podendo ser selecionadas poucas marcas linguísticas para interpretação. Tratase de uma análise vertical e não horizontal. O importante é captar a marca linguística e relacioná-la com o contexto sócio-histórico. (Caregnato; Mutti, op. cit.).

O que se pretende é, através das reações diretas dos usuários e utentes, no fundo do público em geral, verificar da eficácia do discurso técnico habitualmente utilizado.

\section{Discussão}

\section{Introdução}

A apresentação de alguns casos caraterísticos de entre as várias situações encontradas irá permitir uma análise simples da realidade mais vasta que estudámos e que se pretende deixar registada.

Com o presente trabalho pretendemos, em particular, um alerta para a necessidade da comunicação eficaz e eficiente, também para o campo da Saúde, pelo que não temos como objetivo traduzir o discurso particularmente técnico, muitas vezes inacessível aqui apresentado.

Ressalvamos, no entanto, algumas situações em que encontrámos um esforço por parte dos responsáveis dos textos informativos dos medicamentos em alcançarem o público em geral, ao apresentarem uma explicação suplementar simplificada com linguagem acessível do dia-a-dia complementando o texto técnico do folheto informativo. Far-lhe-emos justiça, demonstrando uma situação no ponto segundo com o Medicamento D. 


\section{Análise de casos no âmbito das entrevistas}

- Perante um pedido de esclarecimento a um especialista sobre do que se tratava a esclerose múltipla, obteve-se a seguinte resposta:

"A esclerose múltipla é uma doença inflamatória, que afeta a capa de mielina responsável pela condução nervosa, reconhecida como a substância branca do sistema nervoso."

- Também na tentativa de se entender as causas do hipotiroidismo e como melhor lidar com as doenças da tiroide, o resultado foi o seguinte:

"O hipotiroidismo é uma afecção em que a glândula tiróide tem um funcionamento anómalo e produz muito pouca quantidade de hormona tiróidea. O hipotiroidismo muito grave denomina-se mixedema. (...)

No hipotiroidismo é usada a levotiroxina (...).No hipertiroidismo, também é possível fazer tratamento farmacológico, com o metimazol, (...) Quando estamos perante um bócio nodular tóxico, o tratamento pode ser com iodo radioactivo ou cirúrgico - No caso da Doença de Graves, regra geral, o tratamento é farmacológico (...). poderemos ter de optar pela cirurgia ou pelo tratamento com iodo radioactivo."

- Uma situação distinta, digna de referência, é a de um anúncio informativo a que tivemos acesso através de uma especialista do campo da saúde, que abaixo relatamos na íntegra:

"Quelatos de gadolínio" 2

"O primeiro contraste paramagnético foi aprovado para uso clínico em 1988. O gadolínio $(\mathrm{Gd}+3)$ é um íon metálico paramagnético que reduz o tempo de relaxamento de T1 e T2. Devido à toxicidade de sua forma iônica, ele é usado como um quelato, ou seja, moléculas orgânicas grandes (complexo ligante) formam um complexo estável ao seu redor. O quelato reduz a chance de toxicidade. A freqüência de reações adversas é baixa. Os meios de

2. Por gentiliza da Prof. Dra. Ana Lúcia de Alcantara Oshiro. 
A Comunicação nas ciências interdisciplinares: o compromisso de um discurso - o caso da área da Saúde

contraste paramagnéticos são largamente utilizados e eram considerados seguros, mesmo em pacientes com função renal comprometida. Estes contrastes são rapidamente eliminados em pacientes com função renal normal, entretanto, em pacientes com insuficiência renal a meia-vida é prolongada (34-53 horas). Possíveis efeitos colaterais podem ocorrer devido à meia-vida prolongada ou pela liberação de gadolínio livre (forma iônica $\mathrm{Gd}+3$ ).

Relatos recentes têm demonstrado forte correlação entre o desenvolvimento da FSN e a exposição aos quelatos de gadolínio utilizados em exames de ressonância magnética, especialmente o gadodiamide. Um estudo recente detectou a presença de gadolínio na pele e nos tecidos moles de pacientes com a doença.

Thomas Grobner foi o primeiro a propor esta relação. Ele relata que cinco dos nove pacientes expostos ao gadodiamide, desenvolveram a doença em 2-4 semanas. Descreve ainda que a acidose pode ser um co-fator essencial na patogênese da doença".

In "Fibrose Sistêmica Nefrogênica: possível relação com contrastes à base de gadolínio"

Dr. Sandro Fenelon

\section{Análise de Bulas de medicamentos}

Não é demais recordar que a bula tem a função de informar o modo de tomar o medicamento, assim como de precatar qualquer efeito secundário, advertindo para as interações e efeitos secundários do mesmo. Dirige-se a todos os elementos da sociedade, independentemente do seu grau de escolaridade e integração na sociedade.

Limitar-nos-emos a destacar algumas poucas indicações apresentadas em folhetos de medicamentos obtidos praticamente de forma aleatória.

"Medicamento A

Efeitos Secundários

- (...) Hepatotoxicidade com doses altas (...)

- (...) alterações sanguíneas (trombocitopenia, pancitopenia, neutropenia, agranulocitose e anemia hemolítica 
Interacções Medicamentosas e Outras

- Não se recomenda a administração simultânea de 'Medicamento A' com aspirina, salicicatos (...). O emprego simultâneo de diflunisal com 'Medicamento A' aumenta o risco de hepatotoxicidade. (...). O efeito de 'Medicamento A' é inibido pela administração de colestipol, colestiramina e estrogénios. A isoniazida reforça a capacidade hepatotóxica do Medicamento A"”

"Medicamento B

- Este medicamento contém aspartame. O aspartame é uma fonte de fenilalanina, o que pode ser prejudicial para as pessoas com fenilcetonúria"

"Medicamento C

- Como o perfil antiepiléptico do 'Topiramato' difere acentuadamente do das benzodiazepinas, ele pode modular um subtipo do receptor GABAA insensível à benzodiazepina. O 'Topiramato' antagoniza a capacidade do kainato ativar o subtipo kainato/AMPA (ácido (amino-3- hidroxi-5-metilisoxazol-4-propiônico) do receptor aminoácido excitatório (glutamato), mas não exerce nenhum efeito aparente sobre a atividade do N-metil-D-aspartato (NMDA) no subtipo de receptor NMDA."

"Medicamento D

Indicações terapêuticas (...)

- disminorreia (dores menstruais) (...)

- como analgésico (alívio da dor) ou antipirético ( diminuição da febre) $(. .$.

- (...) ex. luxações - deslocação anormal das extremidades ósseas de uma articulação; (...)

- menorragia ( menstruação anormalmente abundante e que se prolonga para lá da sua duração habitual) Não tome Naproxeno

- Se tem hipersensibilidade (alergia) (...)

- Se alguma vez sofreu de rinite (inflamação aguda ou crónica da mucosa nasal), pólipos (alterações da mucosa nasal) (...)"

Nota: destaques da autora 
A Comunicação nas ciências interdisciplinares: o compromisso de um discurso - o caso da área da Saúde

\section{Conclusões}

Resta-nos umas muito breves considerações em termos de reflexão:

Importa referir que os exemplos aqui apresentados traduzem os resultados generalizados do trabalho efetuado.

Dessa forma:

- Perante o observado verifica-se que estamos perante uma mera informação unidirecional, de elevado pendor técnico, que não cumpre os princípios básicos da comunicação, não tendo em atenção os tipos de público a que se destina.

- Reconhecendo-se na Comunicação, oral e escrita, um papel de primeira linha enquanto elemento que une os distintos elementos da área da saúde, será fundamental que os responsáveis no processo primem para que ela se concretize de forma efetiva e eficiente.

- Atendendo a que os utentes dos serviços médicos e recetores das informações prestadas e cedidas fazem parte de um todo indiferenciado de conhecimentos, cabe aos responsáveis pela informação correspondente à Saúde e à classe médica um esforço para o acompanhamento de todos quanto recorrem ao sistema, independentemente do seu nível de experiências culturais, graus académicos ou especializações técnicas e científicas.

\section{Referências Bibliográficas}

Bertol, S. (s.d.). Comunicação e Sociedade, 41: 258, www.revistas.univerciencia.org.

Caregnato, R.C.A. \& Mutti, R. (2006). Pesquisa qualitativa: análise de discurso versus análise de conteúdo. Texto Contexto Enferm, Out-Dez, 15(4): 679-688. Florianópolis.

Francischett, M.N. (s.d.). O entendimento da interdisciplinaridade no cotidiano. BOCC. www.bocc.ubi.pt.

Hartz, J. \& Chappel, R.W. (1997). Apart: How the Distance Between Science and Journalism Threatens America's Future. First Amendment Center, Nashville.

Japiassu, H. (1976). Interdisciplinaridade e a Patologia do Saber. Rio de Janeiro: Imago. 
Marques de melo, J. (1975). Comunicação Social: teoria e pesquisa. $4^{\mathrm{a}}$. ed. Petrópolis: Vozes.

Mateus, A. (2010, Aug.). Comunicação na saúde - a responsabilidade da física médica. Apontamentos de apoio ao Curso de Física Médica. UFU - Minas Gerais, Brasil

Pêcheux, M. (1993). Análise automática do discurso (AAD-69). In F. Gadet \& T. Hak (Org.). Por uma análise automática do discurso: uma introdução à obra de Michel Pêcheux (pp. 61-105). $2^{\mathrm{a}}$ ed. Campinas (SP): Ed Unicamp.

Perles, J.B. (s.d.). Comunicação: conceitos, fundamentos e história. BOCC. www.bocc.ubi.pt

Sommerman, A. (2006). Inter ou transdisciplinaridade? da fragmentação disciplinar ao novo diálogo entre os saberes. São Paulo: Paulus.

Staudt, D.T. ( 2008). A interdisciplinaridade em atenção básica à saúde. Boletim da Saúde, Jan./Jun., 22(1). Porto Alegre.

Teixeira, J.AC. (1996). Comunicação em saúde - Relação Técnicos de Saúde - Utentes. Notas didácticas. SEAC-Escola de Educação Profissional. Curso Auxiliar de Saúde. www.escolaseac.com

Zorrinho, C. (1995). Gestão da Informação. Condição para Vencer. Iapmei. 


\title{
O Acesso Aberto no Turismo: Resultados preliminares
}

\author{
Cristina Marques Gomes \\ Universidade Federal de Santa Maria \\ E-mail: cristina@usp.br
}

\begin{abstract}
Resumo
Esta pesquisa (financiada pelo Conselho Nacional de Desenvolvimento Científico e Tecnológico - CNPq - Chamada Universal - MCTI/CNPq No 14/2013 - Brasil) tendo como objeto o open acess, apresenta os seguintes objetivos específicos: 1. Identificar e analisar o "quê" os pesquisadores e editores de Turismo no Brasil conhecem sobre o acesso aberto. 2. Averiguar as "motivações" e "barreiras" dos pesquisadores, em Turismo no Brasil, em relação à publicação em acesso aberto. Em termos metodológicos, um primeiro questioná-

Rede de Pesquisadores Acadêmicos em Turismo (REPETUR-Brasil) tendo como fonte/referência o trabalho português "Os Investigadores em Portugal e a sua Relação com o Acesso Aberto à Produção Científica". Outras etapas da pesquisa ainda estão em andamento e/ou por serem executadas. Como contributos finais, trará maior visibilidade sobre o tema na área de Turismo (os pesquisadores que não conhecem o movimento poderão integrar o mesmo) e proporcionará dados confiáveis para o futuro planejamento e prognóstico das publicações científicas brasileiras.
\end{abstract} rio foi aplicado em fevereiro de 2015 à

Palavras-chave: Acesso aberto; Turismo; Brasil e Portugal.

\begin{abstract}
This research (funded by the National Scientific and Technological Development Council - CNPq - Call Universal MCTI / CNPq No. 14/2013 - Brazil) having as object the open acess, has the following specific objectives: 1 . To identify and analyze "what"Tourism researchers

and editors in Brazil know about open access. 2. Identify the "motives"and "barriers" of researchers in Tourism in Brazil, concerning the publication in open access. In terms of methodology, a first questionnaire was administered in February 2015 to the researchers of the Aca-
\end{abstract}


demic Network on Tourism (REPETURBrazil) having as source/reference the Portuguese work "The Researchers in Portugal and its relationship with the Open Access to Scientific Production". Other stages of the research still in progress. As final contributions will bring greater visibility on the topic in the Tourism area (the researchers who did not know the move will integrate the same) and provide reliable data for future planning and prognosis of Brazilian scientific publications.

Keywords: Open access; Tourism; Brazil and Portugal.

\title{
Introdução
}

\begin{abstract}
discussão em torno do acesso aberto dominou praticamente todos os A campos científicos e diversos atores sociais da comunicação científica (CC) - como as bibliotecas, editoras e agências de financiamento - em âmbito internacional. Nos últimos anos, por conseguinte, todo esse contexto externo começou a reverberar no Brasil através do aumento do número de eventos acadêmicos, publicações, políticas, etc. Apesar dessa maximização de debates e ações em torno do open access, de maneira geral, não encontramos quase nenhum trabalho que conjugue este com a área de Turismo. Ao mesmo tempo, o Turismo, no Brasil, é uma disciplina que, cada vez mais, está expandindo o número de periódicos em acesso aberto - o estudo de Miranda ${ }^{1}$ de 2012, indica a existência de 44 revistas e, dessas, 19 são ativas. Ou seja, na prática o acesso aberto é implementado pela ótica dos periódicos - inclusive todos seguem o modelo de negócios do "acesso aberto total" - sem, no entanto, nenhum dado, exame, debate por parte dos pesquisadores e editores em Turismo no Brasil. Tudo são suposições e o futuro da publicação científica, na área, em termos de acesso, difusão e mesmo preservação, depende, sobremaneira, de evidências mais concretas/racionais sobre esse tema, nesse sentido, indagamos:

- Mediante a importância do OA na contemporaneidade, como se sustenta - em termos de informações teóricas sobre o acesso aberto - o conhecimento dos editores e pesquisadores em Turismo no Brasil?
\end{abstract}

1. MIRANDA, E. C. P. (2012). Comunicação Científica em Turismo e o Movimento do Acesso Aberto. In: Congresso Brasileiro de Turismólogos, Belo Horizonte. 
- E, de forma complementar, pela outra via, quais são as crenças e atitudes, traduzidas em "motivações" e "barreiras", dos pesquisadores, desta área, em relação à publicação em acesso aberto?

A partir, portanto, dessas questões, o presente artigo é dividido nos seguintes itens: "objetivos", "considerações metodológicas", "dados descritivos dos resultados preliminares: questionário com os pesquisadores da área de Turismo no Brasil" além das "considerações finais" sobre o tema.

\section{Objetivos}

Objetivo geral: Traçar o perfil do conhecimento teórico absorvido pelos "stakeholders" (pesquisadores e editores) sobre a questão do acesso aberto em Turismo no Brasil e, de forma complementar, entender as "motivações" e "barreiras", dos pesquisadores brasileiros em Turismo, em relação à publicação em acesso aberto.

Objetivos específicos/metas: 1. Identificar e analisar o "quê" os pesquisadores e editores de Turismo no Brasil conhecem sobre o acesso aberto. 2. Averiguar as "motivações" e "barreiras" dos pesquisadores, em Turismo no Brasil, em relação à publicação em acesso aberto.

\section{Considerações metodológicas}

Boa parte da metodologia inicialmente planejada advinha da experiência do Projeto "Study of Open Access Publishing" (Soap) ${ }^{2}$ associado ao "Seventh Framework Programme" (FP7), no entanto, a pesquisa no contexto brasileiro foi limitada em função da falta de capital financeiro, visto que, do montante de 29.977,44 (vinte e nove mil, novecentos e setenta e sete reais e quarenta e quatro centavos) obtivemos o financiamento de 8.700 (oito mil e setecentos reais) - sendo somente 2.700 (dois mil e setecentos reais) de custeio inviabilizando, consequentemente, a viagem para a Suíça. Por outro lado, é de grande valia a organização de estudos/pesquisas que englobem, além de objetos semelhantes, a questão da mesma língua - nesse caso, a portuguesa. Por conseguinte, o projeto, em uma de suas fases, foi direcionado para uma análise comparativa com os resultados obtidos pelo trabalho português "Os Investigadores em Portugal e a sua Relação com o Acesso Aberto à Produção

2. Disponível em: http://project-soap.eu. 
Científica". Um primeiro questionário foi aplicado, via o site survey mon$k e y^{3}$, em fevereiro de 2015 à Rede de Pesquisadores Acadêmicos em Turismo (REPETUR-Brasil) e as questões foram divididas em duas partes - com 10 perguntas cada - sendo que a primeira obteve, até o presente momento, 46 e a segunda, 35 respostas. Os pormenores desses dados serão expostos no item seguinte do presente artigo.

Agregados a esses aspectos, o projeto engloba, ainda:

a) pesquisa bibliográfica: com o propósito de identificarmos outros estudos específicos sobre acesso aberto que, por ventura, tenham sido direcionados a disciplinas específicas (Física, Psicologia e/ou qualquer outra), em âmbito internacional, nos últimos 3 anos. Será dividida em quatro etapas, são elas: "características macro do universo"; "delineamento dos domínios"; "conjunto nuclear de investigações" e "matrizes temáticas e de conceitos" - nos moldes proferidos por Webster e Watson (2002) em "Analyzing the past to prepare for the future: writing a literature review";

b) diálogo com pesquisadores portugueses - e aqui cabe salientar que Portugal é um país de referência e pioneiro no desenvolvimento do open access em escala internacional - incluindo: pesquisa qualitativa; leitura do material disponível no site do "Projetos Open Access da Universidade do Minho" ${ }^{4}$; elaboração metodológica dos dados a serem coletados na visita de campo; viagem - diálogo com um ou mais membro da equipe do "Projetos Open Access da Universidade do Minho" - realização de entrevistas não-estruturadas; tratamento e organização do material; análise e interpretação;

c) Pesquisa com editores da área de Turismo no Brasil: elaboração do questionário; realização do pré-teste; aplicação do questionário; tratamento dos dados; análise e interpretação.

3. Disponível em: https://pt.surveymonkey.com.

4. Disponível em: http://openaccess.sdum.uminho.pt. 


\section{Dados descritivos dos resultados preliminares: questionário com os pes- quisadores da área de turismo do Brasil}

As 4 primeiras questões estavam diretamente relacionadas ao perfil do entrevistado, ou seja, a idade, sexo, escolaridade e profissão e foram assim respondidas:

a) a maioria $(55,56 \%)$ estava na faixa de $31-40$ anos (25 respondentes); em seguida figuravam os respondentes (10) de 41-50 anos; depois, os até 30 anos (4 respondentes; 8,89\%), e, por fim, numericamente iguais (3 respondentes; 6,67\%) surgem as categorias "de 51-60 anos" e "mais de 60 anos";

b) sobre sexo: $51,11 \%$ era feminino e $48,89 \%$ masculino - praticamente iguais, 23 e 22 respondentes, respectivamente;

c) a escolaridade segue a seguinte sequência: doutor $(31,11 \%)$, mestre (26,67\%), doutorando $(24,44 \%)$, pós-doutorado $(15,56 \%)$ e graduação $(0,0 \%)$. Somando "doutor" e "doutorando" temos $55,55 \%$ do total de respondentes.

d) quase todos os respondentes eram docentes da área (36); seguidos de turismólogos (2) e geógrafos (2); e, por fim, com uma resposta cada, estavam as categorias "aposentado"; "guia de turismo e agente de viagem" e "analista de políticas sociais" - essa questão era aberta.

A quinta pergunta era: “concorda com a seguinte afirmação 'não existe qualquer problema com o acesso aberto à informação científica no meu país'"? E, nesse quesito, $67,39 \%$ responderam que discordam; $17,39 \%$ discordam plenamente; $13,04 \%$ concordam; $2,17 \%$ concordam plenamente e nenhum respondente assinalou a alternativa "sem opinião".

Quanto a "qual é a sua opinião em relação às seguintes potenciais barreiras de acesso às publicações científicas?" temos o seguinte quadro: 
Tabela 1. resposta questão 6 - primeira parte do questionário

\begin{tabular}{|c|c|c|c|c|c|c|c|}
\hline$=$ & $\begin{array}{l}\text { Muito } \\
\text { importante }\end{array}$ & Importante - & $\begin{array}{l}\text { Pouco } \\
\text { importante }\end{array}$ & $\begin{array}{l}\text { Nada } \\
\text { importante }\end{array}$ & $\begin{array}{l}\text { Sem } \\
\text { opinião }\end{array}$ & Total - & $\begin{array}{l}\text { Média } \\
\text { ponderada }\end{array}$ \\
\hline $\begin{array}{l}\text { Insuficientes } \\
\text { politicas, } \\
\text { estratégias e } \\
\text { estruturas de } \\
\text { acesso às } \\
\text { publicaçōes } \\
\text { cientificas }\end{array}$ & $\begin{array}{r}34,78 \% \\
16\end{array}$ & $\begin{array}{r}58,70 \% \\
27\end{array}$ & $\begin{array}{r}4,35 \% \\
2\end{array}$ & $\begin{array}{r}0,00 \% \\
0\end{array}$ & $\begin{array}{r}2,17 \% \\
1\end{array}$ & 46 & 1,76 \\
\hline $\begin{array}{l}\text { Elevados preços } \\
\text { dos } \\
\text { artigos/assinaturas } \\
\text { das revistas } \\
\text { cientificas }\end{array}$ & $\begin{array}{r}50,00 \% \\
23\end{array}$ & $\begin{array}{r}36,96 \% \\
17\end{array}$ & $\begin{array}{r}10,87 \% \\
5\end{array}$ & $\begin{array}{r}2,17 \% \\
1\end{array}$ & $\begin{array}{r}0,00 \% \\
0\end{array}$ & 46 & 1,65 \\
\hline $\begin{array}{l}\text { Financiamento das } \\
\text { bibliotecas } \\
\text { reduzido ou } \\
\text { limitado }\end{array}$ & $\begin{array}{r}45,65 \% \\
21\end{array}$ & $\begin{array}{r}45,65 \% \\
21\end{array}$ & $\begin{array}{r}2,17 \% \\
1\end{array}$ & $\begin{array}{r}4,35 \% \\
2\end{array}$ & $\begin{array}{r}2,17 \% \\
1\end{array}$ & 46 & 1,72 \\
\hline $\begin{array}{l}\text { Falta de interesse } \\
\text { e conscientização } \\
\text { da comunidade } \\
\text { científica } \\
\text { relativamente ao } \\
\text { acesso aberto }\end{array}$ & $\begin{array}{r}51,11 \% \\
23\end{array}$ & $\begin{array}{r}28,89 \% \\
13\end{array}$ & $\begin{array}{r}17,78 \% \\
8\end{array}$ & $\begin{array}{r}2,22 \% \\
1\end{array}$ & $\begin{array}{r}0,00 \% \\
0\end{array}$ & 45 & 1,71 \\
\hline $\begin{array}{l}\text { Falta de incentivos } \\
\text { para encorajar } \\
\text { práticas que } \\
\text { promovam o } \\
\text { acesso à produção } \\
\text { cientifica }\end{array}$ & $\begin{array}{r}58,70 \% \\
27\end{array}$ & $\begin{array}{r}32,61 \% \\
15\end{array}$ & $\begin{array}{r}6,52 \% \\
3\end{array}$ & $\begin{array}{r}0,00 \% \\
0\end{array}$ & $\begin{array}{r}2,17 \% \\
1\end{array}$ & 46 & 1,54 \\
\hline
\end{tabular}

"Elevados preços dos artigos/assinaturas das revistas científicas", "Falta de incentivos para encorajar práticas que promovam o acesso à produção científica" e "falta de interesse e conscientização da comunidade científica relativamente ao acesso aberto" foram apontadas como "muito importantes"; "financiamento das bibliotecas reduzido ou limitado" adquiriu de forma equivalente a mesma porcentagem nas categorias "muito importante" e "importante". E "Insuficientes políticas, estratégias e estruturas de acesso às publicações científicas" foi classificada como "importante".

O conceito de acesso aberto foi explorado em duas questões: a primeira era "conhece e compreende o conceito de acesso aberto (Open Access) à produção científica?" e a segunda "se sim, descreva". 37 responderam "sim", ou seja, $80,43 \%$ e 9 "não", correspondente a 19,57\%. As respostas descritivas englobavam: de um lado o acesso aberto de forma genérica (18 respostas - como, por exemplo, "acesso livre, transparente e gratuito"), e, de outro, o acesso aberto em oposição ao pagamento (13 respostas - como, por exemplo, "acesso aberto, sem taxas, assinaturas, etc") e, por outra via, algumas respostas (3) apresentavam um caráter mais "explicativo" - incluindo a iniciativa de um "movimento", as "pesquisas oriundas de projetos financiados por 
programas públicos" e "produzidas por instituições públicas"; e, por fim, três respostas classificadas como "contraditórias" - associando o acesso aberto com a não "avaliação prévia pelo editor e posteriormente pelos pares", outra que afirmava que "o crivo financeiro para a publicação retira a isenção das bancas julgadoras" e que "é uma plataforma online de parceria entre IES e periódicos".

A nona questão da primeira parte do questionário era "qual a sua opinião em relação às seguintes afirmações" - estas expostas no quadro abaixo:

Tabela 2. resposta questão 9 - primeira parte do questionário

\begin{tabular}{|c|c|c|c|c|c|c|c|}
\hline v & $\begin{array}{l}\text { Concordo } \\
\text { plenamente }\end{array}$ & Concordo - & $\begin{array}{l}\text { Sem } \\
\text { opinião }\end{array}$ & Discordo - & $\begin{array}{l}\text { Discordo } \\
\text { plenamente }\end{array}$ & Total - & $\begin{array}{l}\text { Média } \\
\text { ponderada }\end{array}$ \\
\hline $\begin{array}{l}\text { O acesso } \\
\text { aberto irá } \\
\text { alterara a } \\
\text { comunicação } \\
\text { científica na } \\
\text { minha área } \\
\text { de } \\
\text { investigação } \\
\text { nos próximos } \\
\text { anos }\end{array}$ & $\begin{array}{r}34,78 \% \\
16\end{array}$ & $\begin{array}{r}34,78 \% \\
16\end{array}$ & $\begin{array}{r}19,57 \% \\
9\end{array}$ & $\begin{array}{r}6,52 \% \\
3\end{array}$ & $\begin{array}{r}4,35 \% \\
2\end{array}$ & 46 & 2,11 \\
\hline $\begin{array}{l}\text { O acesso } \\
\text { aberto } \\
\text { aumenta o } \\
\text { número de } \\
\text { citaçôes dos } \\
\text { meus } \\
\text { trabalhos de } \\
\text { investigação }\end{array}$ & $\begin{array}{r}47,83 \% \\
22\end{array}$ & $\begin{array}{r}43,48 \% \\
20\end{array}$ & $\begin{array}{r}4,35 \% \\
2\end{array}$ & $\begin{array}{r}4,35 \% \\
2\end{array}$ & $\begin{array}{r}0,00 \% \\
0\end{array}$ & 46 & 1,65 \\
\hline $\begin{array}{l}\text { O acesso } \\
\text { aberto } \\
\text { aumenta o } \\
\text { acesso a } \\
\text { disseminação } \\
\text { das } \\
\text { publicações } \\
\text { científicas }\end{array}$ & $\begin{array}{r}69,57 \% \\
32\end{array}$ & $\begin{array}{r}30,43 \% \\
14\end{array}$ & $\begin{array}{r}0,00 \% \\
0\end{array}$ & $\begin{array}{r}0,00 \% \\
0\end{array}$ & $\begin{array}{r}0,00 \% \\
0\end{array}$ & 46 & 1,30 \\
\hline $\begin{array}{l}\text { O acesso } \\
\text { aberto à } \\
\text { produção } \\
\text { científica } \\
\text { pode } \\
\text { coexistir com } \\
\text { o tradicional } \\
\text { modelo de } \\
\text { publicação } \\
\text { científica }\end{array}$ & $\begin{array}{r}28,26 \% \\
13\end{array}$ & $\begin{array}{r}43,48 \% \\
20\end{array}$ & $\begin{array}{r}10,87 \% \\
5\end{array}$ & $\begin{array}{r}15,22 \% \\
7\end{array}$ & $\begin{array}{r}2,17 \% \\
1\end{array}$ & 46 & 2,20 \\
\hline
\end{tabular}

Já a décima pergunta era "qual a sua opinião sobre o princípio da disponibilização em acesso aberto das publicações científicas resultantes de projetos financiados por programas públicos?" com 39 respondentes, ou seja, 84,78\% afirmando que "concordo plenamente", 7 respondentes $(15,22 \%)$ com o "concordo" e $0 \%$ "sem opinião", "discordo" e "discordo plenamente". 
Para a segunda parte do questionário o respondente tinha que "clicar" num outro link e, dos 46 ativos, somente 35 migraram de uma parte para a outra revelando, pois, em certo sentido, o "desinteresse" da comunidade acadêmica de Turismo no Brasil pela temática do acesso aberto. Os dados descritivos são assim apresentados:

1. Como reagiria perante um mandato de acesso aberto à produção científica implementado por órgãos governamentais do seu país? (Capes, $\mathrm{CNPq}$, etc - no caso brasileiro)

Tabela 3. resposta questão 1 - segunda parte do questionário

\begin{tabular}{|l|lc}
\hline Opções de resposta & Respostas \\
\hline Cumpriria integralmente com facilidade & $82,86 \%$ & 29 \\
\hline Cumpriria integralmente com desagrado & $5,71 \%$ & 2 \\
\hline Cumpriria parcialmente & $11,43 \%$ & 4 \\
\hline Não cumpriria & $0,00 \%$ & 0 \\
\hline Total & & 35 \\
\hline
\end{tabular}

2. Na sua opinião, qual a forma mais fácil de satisfazer os requisitos de uma política obrigatória de acesso aberto à produção científica?

Tabela 4. resposta questão 2 - segunda parte do questionário

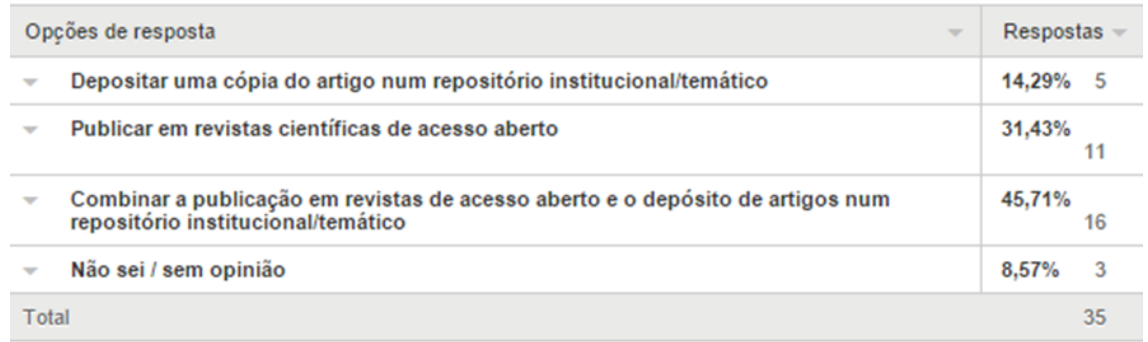

3. Na sua opinião, se o editor definir um período de tempo durante o qual sua publicação não pode estar em acesso aberto, devem ser considerados: 
Tabela 5. resposta questão 3 - segunda parte do questionário

\begin{tabular}{l|lc}
\hline Opções de resposta & Respostas \\
\hline-6 meses & $25,71 \%$ & 9 \\
\hline 9 meses & $0,00 \%$ & 0 \\
\hline$\quad 12$ meses & $11,43 \%$ & 4 \\
\hline$\quad 18$ meses & $0,00 \%$ & 0 \\
\hline$\quad$ Sem período de embargo, imediatamente disponivel & $54,29 \%$ & 19 \\
\hline$\quad$ Não sei / sem opinião & $8,57 \%$ & 3 \\
\hline Total & \multicolumn{2}{|c}{3} \\
\hline
\end{tabular}

4. O acesso aberto pode ser relevante não apenas para as publicações mas também para os dados científicos. Qual a sua opinião sobre o princípio da disponibilização em acesso aberto dos dados científicos resultantes de projetos financiados por programas públicos?

Figura 1. resposta questão 4 - segunda parte do questionário

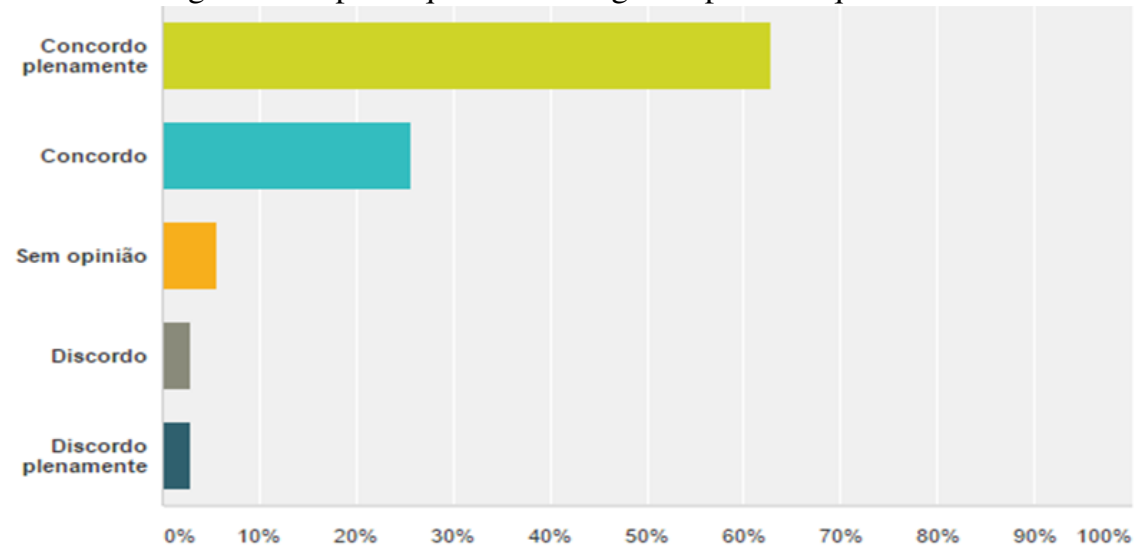

5. Indique o número de publicações que melhor define a sua produção científica anual: 
Figura 2. resposta questão 1 - segunda parte do questionário

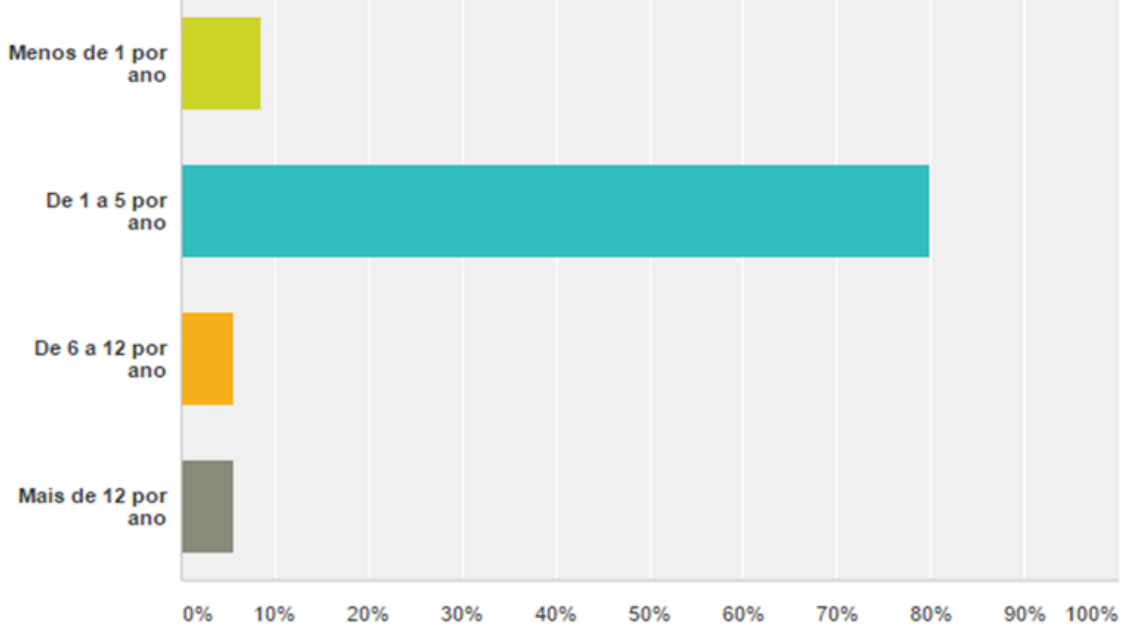

6. Já disponibilizou alguma das suas publicações em acesso aberto?

Tabela 6. resposta questão 6 - segunda parte do questionário

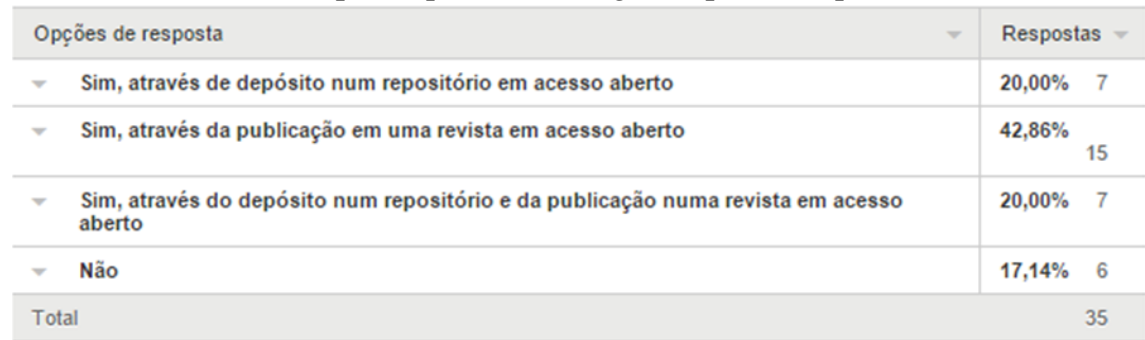

7. Indique o número aproximado dos artigos em acesso aberto: 
Tabela 7. resposta questão 7 - segunda parte do questionário

\begin{tabular}{|c|c|c|c|}
\hline Opções de resposta & $=$ & Respostas & $\checkmark$ \\
\hline Depositados em repositórios institucionais & Respostas & $62,50 \%$ & 15 \\
\hline Depositados em repositórios temáticos & Respostas & $54,17 \%$ & 13 \\
\hline Publicados em revistas cientificas em acesso aberto & Respostas & $91,67 \%$ & 22 \\
\hline
\end{tabular}

8. Na sua opinião, quais são os TRÊS principais motivos para proceder ao depósito dos seus artigos científicos em repositórios institucionais / temáticos (Indique no máximo 3 motivos)

Tabela 8. resposta questão 8 - segunda parte do questionário

\begin{tabular}{|c|c|c|c|}
\hline Opções de resposta & $\checkmark$ & Respostas & $\checkmark$ \\
\hline Aumenta a visibilidade e o impacto (citaçöes) da pesquisa & & $70,59 \%$ & 24 \\
\hline Aumenta a rapidez de disseminação dos resultados da pesquisa & & $67,65 \%$ & 23 \\
\hline É obrigatório na minha instituição & & $17,65 \%$ & 6 \\
\hline Posso delegar essa tarefa em outra pessoa & & $2,94 \%$ & 1 \\
\hline Existe suficiente suporte técnico na minha instituição & & $0,00 \%$ & 0 \\
\hline A editora autoriza o depósito em repositórios institucionais & & $0,00 \%$ & 0 \\
\hline O processo de depósito é rápido e simples & & $17,65 \%$ & 6 \\
\hline É um requisito do financiador da minha pesquisa & & $5,88 \%$ & 2 \\
\hline É uma forma de preservar a minha produção cientifica & & $50,00 \%$ & 17 \\
\hline Publico em revistas de acesso aberto & & $38,24 \%$ & 13 \\
\hline
\end{tabular}

9. Na sua opinião, quais são os TRÊS principais motivos para não depositar os seus artigos científicos num repositório institucional / temático (indique no máximo 3 motivos): 
Tabela 9. resposta questão 9 - segunda parte do questionário

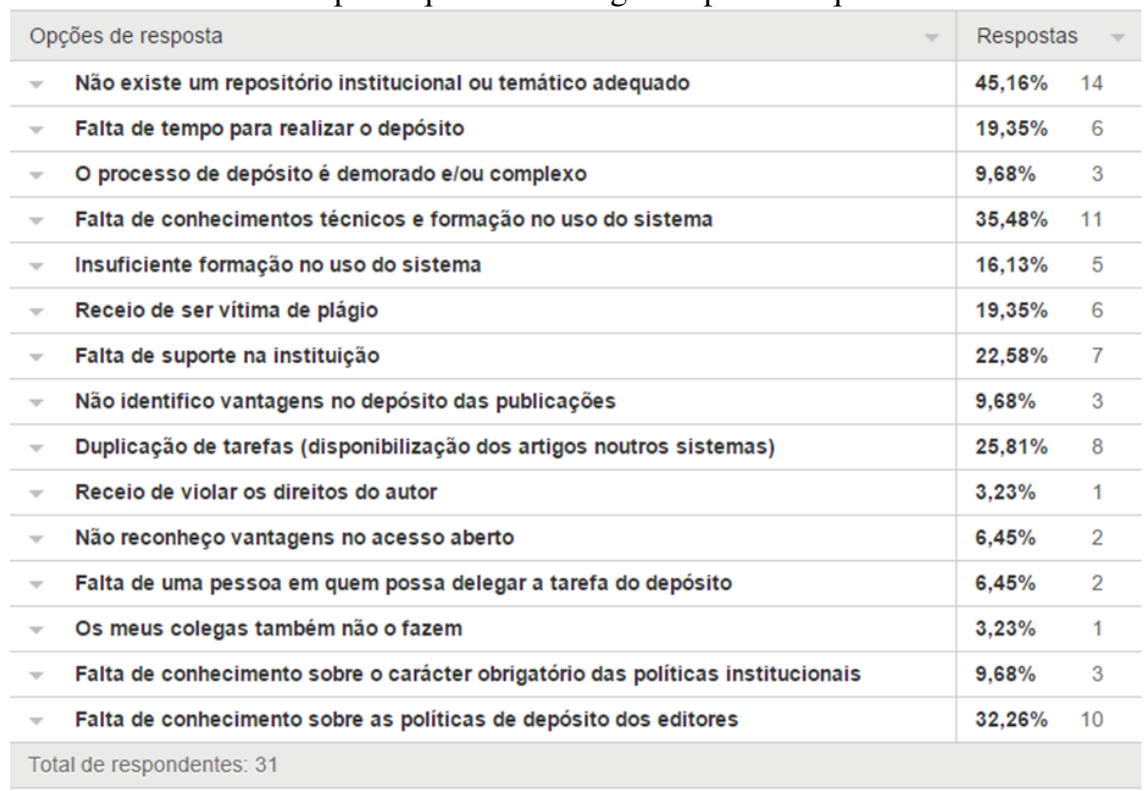

A décima questão da segunda parte era "aberta" para "comentários gerais" e obteve 7 respostas completamente distintas como, por exemplo, "interessante pesquisa e interessante discussão. Falta conhecimento sobre a existência de publicações de acesso aberto no Brasil e no exterior e qual o reconhecimento que será dado pelo meio científico e pelo CAPES/CNPQ para este tipo de publicação. E como são classificadas estas publicações quanto ao Qualis?" e "acredito que o conceito de metadados no acesso aberto é algo que deve ser fortemente incentivado".

\section{Considerações finais}

Podemos afirmar que os nossos principais contributos, são: de um lado a composição do perfil do conhecimento teórico sobre o acesso aberto, por parte dos pesquisadores e editores de Turismo no Brasil que, pelo viés holístico, poderá sustentar outras investigações de diferentes naturezas, inclusive, porque, o acesso aberto e a própria comunicação científica são objetos de estudo que atravessam horizontalmente, praticamente, quando não, todas as disciplinas, 
mesmo diante das singularidades de cada uma, ampliando exponencialmente a relevância do presente projeto de pesquisa para o Turismo e outras áreas potenciais; e, de outro, a verificação das "motivações" e "barreiras" dos pesquisadores de Turismo no Brasil em relação à publicação em acesso aberto. De maneira geral, também, a presente pesquisa trará maior visibilidade sobre o tema na área de Turismo (os pesquisadores que não conhecem o movimento poderão integrar o mesmo) e proporcionará dados confiáveis para o futuro planejamento e prognóstico das publicações científicas brasileiras.

Cabe salientar, ainda, que o presente artigo não cobre os aspectos interpretativos dos dados coletados e, também, não adentra as correlações desses com a literatura corrente - por ser uma pesquisa em andamento cujo final está previsto para dezembro de 2016.

\section{Referências}

Anton, B. (2003). Issues and impacts of the changing nature of Scientific Communication. Optometry and Vision Science, 80(6): 403-410.

Atkinson, R.C. (2003). A new world of Scholarly Communication. Chronicle of Higher Education, 50(11): 16.

Bergman, S. (2006). The Scholarly Communication movement: highlights and recent developments. Collection Building, 25(4): 108-128.

Bjork, B.-C. (2007). A Model of Scientific Communication as a global distributed information system. Information Research , 12, jan.

Borgman, C.L. (2000). Digital libraries and the continuum of Scholary Communication. Journal of Documentation, 56(4).

Friedlander, A. (2008). The Triple Helix: Cyberinfrastructure, Scholarly Communication, and trust. Journal of Electronic Publishing, 11.

Fyffe, R. (2002). Technological change and the Scholarly Communications reform movement: reflections on Castells and Giddens. Library Resources and Technical Services, 46(2): 50-61.

Gomes, C.M. (2013). Comunicação Científica: Alicerces, transformações e tendências. Covilhã, UBI, LabCom, Livros LabCom.

Gomes, C.M. (2010). Paradigma do Acesso Aberto (Open Access): alguns apontamentos para os estudiosos do Turismo no Brasil. Turismo em Análise, 21(2). 
Guédon, J.-C. (2001). Oldenburg's long shadow: librarians, research scientists, publishers and the control of scientific publishing. Creating Digital Future, maio.

Hahn, K. (2006). New tools for new times: remodeling the Scholarly Communication system. College \& Research Libraries News, 67(10).

Harnad, S. (2007). Entrevista com Steven Harnad (versão Hélio Kuramoto). Bibli.: R. Eletr. Bibliotecon. Ci. Inf., Florianópolis, n. Esp., $1^{\circ}$ sem.

Harnad, S. (1998). Learned inquiry and the net: the role of peer review, peer commentary and copyright. Learned Publishing, 11(4).

Harnad, S. (1991). Post-Gutenberg galaxy: the fourth revolution in the means of production of knowledge. Public-Access Computer Systems Review, 2(1): 39-53.

Harnad, S. (1990). Scholarly skywriting and the prepublication continuum of scientific inquiry. American Psychological, 1(6).

Harnad, S. (2006). Optimizing OA self-archiving mandates: what? where? when? why? How? Technical Report, ECS, University of Southampton.

Hjorland, B. (2002). Domain analysis in Information Science: eleven approaches

Hurd, J.M. (1996). Models of Scientific Communications systems. S.Y. Crawford; J.M. Hurd \& A.W. Weller, From Print o Electronic: The Transformation of Scientific Communication. USA: Information Today.

Kling, R. (2000). Learning about information technologies and social change: The contribution of social informatics. Information Society, 16(3): 217232.

Kling, R. (2004). The internet and unrefereed scholarly publishing. Annual Review of Information Science and Technology, 38: 591-631, xix-xx.

Lagoze, C. \& Van de Sompel, H. (2001). The Open Archives Initiative: building a low-barrier interoperability framework. Joint Conference on Digital Libraries, 1.

Lynch, C. (2003). The transformation of Scholarly Communication and the role of the libray in the age of networked communication. Serials Librarian, 3: 5-20. 
Meyer, E.T. \& Schroeder, R. (2009). The world wide web of research and access to knowledge. Knowledge Management Research and Practice, 7(3): 218-233.

Odlyzko, A. (2002). The rapid evolution of Scholarly Communication. Learned Publishing, 15: 7-19.

Pikas, C.K. (2006). The impact of information and communication technologies on informal scholarly Scientific Communication: a literature review. Prepared for LBSC878: Doctoral Seminar in Information Studies. USA: University of Maryland College of Information Studies.

Rowlands, I. (2003). Knowledge production, consumption and impact: policy indicators for a changing world. Aslib Proceedings, 55(1-2): 5-12.

Schroeder, R. \& Fry, J. (2007). Social science approaches to e-science: framing an agenda. Journal of Computer-Mediated Communication, 12(2).

Sondergaard, T.; Andersen, J. \& Hjorland, B. (2003). Documents and the communication of scientific and scholarly information revising and updating the UNISIST Model. Journal of Documentation, 59: 278-320.

Tenopir, C. \& King, D.W. (2000). Towards electronic journals - realities for scientists, librarians and publishers. USA: Special Libraries Association.

Vickery, B.C. (2000). Scientific Communication in history. London: The Scarecrow Press. 
$\bigoplus$

$\bigoplus$

$\oplus$ 


\title{
Carbon Dust na comunicação científica - potencialidades e perspetiva
}

\author{
Sofia M. Ferreira \& Fernando J. Correia \\ ... \\ E-mail: sofiamdsfegmail.com
}

\begin{abstract}
Resumo
A utilização da ilustração científica, para comunicar e divulgar ciência, tem como base a compilação/seleção e a codificação visual de uma mensagem, no formato de imagem construída de modo a poder transmitir o conhecimento científico, de forma fluída e eficaz, informando. Ela deve também estimular e motivar uma necessidade do observador. Comunicar Ciência de forma visual denota uma forte dependência das técnicas de expressão plástica adotadas para atingir um determinado fim figurativo/representativo de forma expedita, credível e mimético com o objeto de estudo, ideia ou modelo real a ilustrar. A ilustração científica também é sublimada pelas potencialidades do carvão e a evolução técnica para a "pintura"

proporcionada pelo pó de carvão - Carbon Dust. O seu potencial foi realçado através da ilustração médica e dos trabalhos pioneiros e intemporais de Max Brödel (1911). A contemporaneidade da técnica é tal que, ainda hoje, é aí leccionada a metodologia proposta por Brödel, tendo inclusive ultrapassado fronteiras (como no Canadá e na Europa, mais precisamente no Curso de Formação em Ilustração Científica ministrado na Universidade de Aveiro). Nesta comunicação pretendeu-se realçar a importância da técnica do Carbon Dust aplicada à ilustração científica, num sentido mais amplo, realçando as suas potencialidades na figuração anatómica.
\end{abstract}

Palavras-chaves: ilustração científica; comunicar e divulgar ciência; ilustração médica; técnica do Carbon Dust.

\begin{abstract}
The use of scientific illustration to communicate and disseminate science is based on the collection / selection and visual encoding of a message, in the format of an image constructed to be able

to transmit scientific knowledge in a fluid and effective way. It should also stimulate and motivate an observer's need. To communicate Science visually denotes a strong dependence on plastic expression
\end{abstract}


techniques used to achieve a particular purpose figurative / representative in an expeditious manner, credible and mimetic with the study object, idea or real model to illustrate. The scientific illustration is also sublimated by coal potentialities and the technical evolution of the "painting" provided by coal dust - Carbon Dust. Its potential was emphasized by medical illustration and by Max Brodel (1911) pioneers and timeless works. The contemporaneity technique is such that, even today, it is taught the proposed Brodel's methodology, having even exceeded borders (as in Canada and Europe, more precisely in the Training Course in Scientific Illustration taught at the University of Aveiro). In this communication it is intended to enhance the importance of Carbon Dust technique applied to scientific illustration, in a broader sense, enhancing their potential in the anatomical figuration.

Keywords: scientific illustration; communicate and disseminate science; medical illustration; Carbon Dust technique.

C ONSIDERA-SE um desenho/ilustração científica, toda e qualquer imagem desenhada que exibe rigor, correção e objectividade na mensagem que transmite, sempre no domínio do conhecimento científico e dentro do estado da Ciência patente e aceite nesse momento. A ilustração científica tem assim a função prioritária de codificar visualmente e veicular uma mensagem científica (uma ideia ou tese, uma interpretação, uma observação), de forma tacitamente credível, acessível e passível de ser entendida e utilizada por várias audiências (especializadas e/ou não-especializadas), tanto em Portugal como em qualquer outra parte do Mundo, ultrapassando obstáculos idiomáticos, culturais e outros (Correia, 2009a).

Uma ilustração científica é uma imagem pensada e construída que representa com rigor diversos assuntos ligados às Ciências, adaptando-se a domínios tão diferentes como a Biologia, a Medicina, a Paleontologia, a Geologia, a Antropologia, etc. Para tal e tendo como objetivo maior a apreensão desse conhecimento em particular, deve sempre respeitar três premissas basilares e simultâneas na sua construção e formatação: 1) compilar/condensar/informar; 2) transmitir o conhecimento científico, de forma fluída e eficaz, informando e 3) estimular/motivar através de uma codificação visual da informação (Correira, 2009a, 2010, 2011a e 2011b). Só assim ela poderá ter valor documental e ser utilizada para comunicar e divulgar ciência, estimulando e motivando uma necessidade do observador. Comunicar Ciência de forma visual denota 
uma forte dependência das técnicas de expressão plástica adotadas para atingir um determinado fim figurativo/representativo de forma expedita, credível e mimético com o objeto de estudo, ideia ou modelo (arquétipo) real a ilustrar. Segundo Correia (2011c:45), "converter Ciência em Imagem desenhada é, antes de tudo, um exercício de reflexão e interpretação, uma incessante procura de contornos heurísticos, da Universalidade e do Imediatismo, da Comunicabilidade. Só depois é traço e cor". Por todas as premissas e convenções a que é sujeita, dentro do discurso científico a que está subordinada, considera-se que a ilustração científica é assim uma imagem útil, credível e honesta.

Desde os tempos mais remotos da Humanidade, o Homem tem recorrido a desenhos/esboços para comunicar, como o testemunham numerosas pinturas rupestres (os primeiros murais), no sentido de extravasar e ir além do indivíduo (permitir que outro absorva, interiorize e faça uso de um conhecimento que não é da sua génese). Um exemplo, com mais de 18000 anos, são as pinturas rupestres da gruta Chauvet (localizada na Ardèche, França) atribuídas à época do Paleolítico médio superior e descoberta por acaso, em 1994, pelo espeleólogo Jean-Marie Chauvet. Esta estação pré-histórica reúne mais de mil pinturas e gravuras e onde se representaram cerca de 425 animais de 14 espécies diferentes (Combier \& Jouves, 2014), de grande qualidade estética e rigor - se tivermos em conta as restrições técnicas à época e limitações na metodologia do desenho em si, enquanto função de representação.

A comunicação visual através do desenho faz assim parte da natureza e da essência do Homem desde os primórdios da sua Cultura - é algo que ilustra e elucida, que torna mais claro, que ilumina. Neste sentido, e ao longo dos séculos, vários dos materiais utilizados nesses primeiros murais, foram sendo aperfeiçoados entre os quais se destacam as tintas criadas a partir da mistura de um pigmento com uma gordura (derivando daí os óleos, ou até o conceito das minas dos lápis de cor) ou ainda o carvão natural (arcaico, mas que sobreviveu na sua simplicidade até à atualidade na sua forma natural, quando muito sintetizado). O carvão vegetal ou carvão natural pode ser obtido através da queima controlada de vários tipos de madeira de árvores típicas das regiões temperadas, como o salgueiro, a tília, a nogueira, ou ainda arbustos, como a videira. A condição essencial para a adequação é a homogeneidade do material lenhoso ao longo do ramo, capaz de exibir uma boa densidade após a queima, traduzível numa multiplicidade de negros por ação de risco. Pela condição do próprio fabrico (redução da matéria orgânica à sua forma carbo- 
nizada), o carvão é um material friável e de difícil conservação. Atualmente pode ser disponibilizado em várias formas, com diferentes características: 1) carvão em galho natural quando se apresenta na sua forma original de ramo carbonizado, sendo o mais suave o galho de vinha; 2) carvão em barra regular de cerca de $18 \mathrm{~cm}$ de comprimento e um máximo de cerca de $1 \mathrm{~cm}$ de diâmetro, de aspeto cilíndrico ou paralelepipédico e em três consistências: macia, média e dura; 3) carvão sintético, mais resistente, obtido pela redução a pó de madeira carbonizada, posteriormente consolidada com um ligante e que depois é injetada e comprimida em formas que permitam o risco ( 9 a $12 \mathrm{~cm}$ de comprimento e uma grossura de cerca de $0,6 \mathrm{~cm})$; 4) lápis de carvão, com uma gama de expressão de traço que vai do 6B (muito macio) ao HB (duro), e em que basicamente o carvão sintético é utilizado na produção de minas cilíndricas de pequena espessura e cuja resistência à quebra é assegurada pelo envolvimento em capa de papel enrolado (em tortillon) ou madeira de cedro americano e 5) carvão em pó (Stanyer, 2003).

Por ser um material com uma muito fraca aderência ao papel (sem capacidade adesiva ou complementos cerosos), facilmente se subtrai à superfície onde foi depositado, razão pela qual desde a Idade Média a ele se recorre mais no intuito de realizar esboços preliminares que sirvam de base a posterior aplicação de tintas com capacidade opacificadora (óleo ou têmpera). A partir do Renascimento, tendo em conta que os materiais para a elaboração dos efeitos de luz/sombra começam a ser privilegiados no desenho, adquire uma expressão mais tonal e uma mais distintiva receção. De facto e por volta do século XVI este torna-se o instrumento mestre para a realização de figuras movimentadas, adquirindo a "arte do carvão"o estatuto de disciplina própria e independente no mundo das Belas Artes, com ampla difusão e aceitação entre os artistas dos ateliers venezianos, florentinos e romanos.

No campo da ciência, sendo que o que importa é a massificação do tratado científico (divulgação e disseminação) e não a singularidade da obra (que no campo artístico se quer não somente original, como única), o certo é que o carvão não será adoptado como técnica para a execução das primeiras imagens a serem reproduzidas nas obras científicas por então editadas. Esta realidade mantem-se inalterada, não por causas próprias das limitações da técnica em si, mas sim das técnicas de reprodução através da impressão da imagem desenhada - algo que só mudou com o advento do offset, em 1904. Volvido um século e com o advento da técnicas de impressão digital a partir de 1993, 
a ilustração científica executada em carvão ganha assim uma outra oportunidade, dinamismo e potencialidades (Correia \& Ismar, in publication).

A ilustração científica, no seu sentido mais contemporâneo e de como hoje a entendemos, apropriou-se também de mais esta técnica de expressão plástica como uma outra ferramenta para atingir os seus objetivos na complementaridade do discurso científico, mais ainda após a sua evolução de mono-risco para um poli-risco que simula o efeito de continuidade propiciado pela "pintura" a pincel seco com pó de carvão - e que originalmente se designou por Carbon Dust. O seu potencial foi realçado através da ilustração médica e dos trabalhos pioneiros e intemporais do jovem artista alemão Paul Heinrich Max Brödel (1870-1941), que viria a ser o primeiro Diretor do Departamento de Artes aplicadas à Medicina, da Universidade John Hopkins (1911), em Baltimore. Este dotado artífice chega a essa universidade, sem formação em ciência e a convite de Franklin P. Mall (1862-1917; futuro Diretor do Serviço de Anatomia), em 1894, integrando os serviços da recém-fundada Faculdade de Medicina. No entanto, as suas elevadas competências na tradução gráfica de observações médicas, permite-lhe ser tutorado pelo professor de ginecologia clínica Howard Atwood Kelly (1858-1943), que o formata para as dificuldades do que se lhe iria exigir: até 1898, produz 154 ilustrações de elevada qualidade para o primeiro volume do livro de Kelly "Operative Gynecology", seguindose cinco anos mais tarde, o segundo volume com 207 ilustrações de Brödel. De todo o processo, segundo Schultheiss, Engel, Crosby, Lees, Truss \& Jonas (2000 apud:1137) Max Brödel intuitivamente assumiu uma importante conclusão que seria determinante para o seu trabalho posterior: "É necessário para originar um tipo diferente de imagem, criar uma que mostre muito mais do que qualquer fotografia jamais poderia fazer. $\mathrm{O}$ artista deve compreender plenamente o assunto de cada ponto de vista: anatómico, topográfico, histológico, patológica, médico e cirúrgico. Destes conhecimentos acumulados cresce uma imagem mental, a partir do qual ele delimita o plano do futuro desenho. O planeamento da imagem, portanto, é a coisa mais importante, não a sua execução."Se por um lado Brödel teve uma formação clássica no campo das artes plásticas, por outro lado e mercê da continuada prática médica (observação) ganhou a clareza suficiente para perceber a extrema importância em se inteirar com rigor e objetividade das noções científicas necessárias aos temas a ilustrar. Assim e ao longo da sua carreira de ilustrador médico, foi incentivado e motivado a realizar aturados estudos de anatomia e patologia em 
cadáveres, bem como a frequentar as salas de operações, ou seja, ele mesmo se tornou um anatomista. Grande conhecedor dos tecidos vivos, assumiu o papel de um verdadeiro cientista em uroginecologia, realizando importantes contribuições para a medicina, tais como "Brödel white line" ou ainda "the Brödel suture". Mas não só se distinguiu no campo científico, como também em termos mais artístico, ao ser o responsável pelo desenvolvimento de uma nova técnica de desenho recorrendo a um material simples, mas expedito, que hoje dá pelo nome de Carbon Dust ou pó de carvão (Froeshner \& Druckenbrod, 2003; Schultheiss et al., 2000; Schultheiss \& Jonas, 1999).

A contemporaneidade da técnica é tal, que ainda hoje, esse método de figuração suportada pela pintura em seco com carvão é aí leccionada, a par do que sucede em vários outros países. Por exemplo, em 1925, foi instituído no Canadá o Departamento de Serviço de Arte Médica da Universidade de Toronto, por Maria Wishart. Com o início da Segunda Guerra Mundial, o Dr. J. C. B. Grant vê a oportunidade, através de uma equipa de ilustradores essencialmente femininos e altamente qualificados, de criar um Atlas que visualmente descrevesse os processos anatómicos humanos. Esta publicação, Grant - Atlas de Anatomia, teve um enorme impacto na altura e ainda hoje constitui uma obra de referência na formação dos estudantes de medicina em todo o mundo (Czegledy, 2010).

Na Europa, mais precisamente em Portugal, um país com tradições seculares no âmbito da figuração naturalista (biológica), podemos avançar que muitos dos primeiros ilustradores científicos portugueses (por então designados por riscadores) e que acompanharam as expedições científicas do período dos Descobrimentos, também terão recorrido ao carvão. Por outro lado e no contexto de formação, e já no século XVIII, inicia-se o ensino formal dos princípios que regem a ilustração científica na Casa do Risco. Já em meados do século XX, surgem várias disciplinas no âmbito do ensino universitário ligadas à ilustração, as quais devido a reforma do Ensino Superior que se seguiu à Revolução dos Cravos (1974) deixaram de existir. Será necessário esperar o ano de 1996, com a instituição da disciplina Métodos de Ilustração Biológica, na Universidade de Évora e ministrada pelo Dr. Fernando Correia, para um "renascimento"da ilustração científica propriamente dita enquanto disciplina integrada em cursos superiores de ciências naturais e num contexto do ensino formal (Correia, 2010). Mais tarde, em 2011, o Departamento de Biologia da Universidade de Aveiro aposta na edificação do Laboratório de Ilustração Ci- 
entífica (LIC) e ainda no Curso de Formação em Ilustração Científica (CFIC) ambos criados e sob a direção do Dr. Fernando Correia, o qual retoma a tradição do ensino atualizado das técnicas de carvão, por se reconhecer a sua pertinência e atualidade.

No intuito de demonstrar as potencialidades da aplicação desta técnica também à figuração biológica, além da médica, e a sua importância no contexto da ilustração científica enquanto vertente visual da comunicação científica, representou-se a espécie de crustáceo cuja frequência de ocorrência em Aveiro é elevada - o caranguejo-verde (Carcinus maenas; Filo Arthropoda, Família Portunidae). Sendo que a ilustração científica de uma espécie não é o desenhar de um indivíduo, mas assenta na criação de um modelo ou arquétipo visual que seja representativo do cumulativo das características que a identificam, seguiu-se a metodologia acima descrita em 3 passos.

Antes de se iniciar o trabalho gráfico e a escolha da pose em função do objetivo a alcançar, foi imprescindível uma extensa pesquisa de informação descritiva e visual por forma a listar todos os carateres com valor diagnosticante, passíveis de serem figurados e que promovam a identificação da espécie de forma inequívoca. Carcinus maenas é uma espécie invasora que apresenta dimorfismo sexual (o indivíduo masculino apresenta um abdômen de forma triangular, enquanto as fêmeas um abdômen de forma mais arredondado). Pertencendo a ordem Decapoda exibe uma carapaça grossa que apresenta cabeça e tórax soldados entre si (formando o cefalotórax), de abdómen reduzido e olhos pedunculados e móveis. Esta espécie distingue-se das outras por apresentar: 1) três dentes arredondados na fronte; 2) bordos ântero-laterais da carapaça providos de cinco dentes dirigidos para diante; 3) último artículo do quinto par de patas caracteriza-se por ser estreito e agudo; 4) aproximadamente $7 \mathrm{~cm}$ de largura e 5) de coloração esverdeada (Saldanha, 2003; Barres \& Muñoz, 2000).

Face a abundância da espécie na costa de Aveiro, foi possível estudar e observar vários indivíduos da espécie, que foram igualmente fotografados, um dos quais foi ainda preparado e montado na posição escolhida (em placa de esferovite e recorrendo a alfinetes para o posicionamento correto do corpo e apêndices), sendo posteriormente conservado (por congelação), para futuras observações na eventualidade de ser necessário esclarecer dúvidas pontuais sobre a anatomia da espécie (figura 1). A escolha da pose em vista dorsal tem como justificação o ser aquela que acarreta um aporte de maior familiaridade 
no reconhecimento da forma, que tipifica o grupo de artrópodes em causa (Correia, 2012).

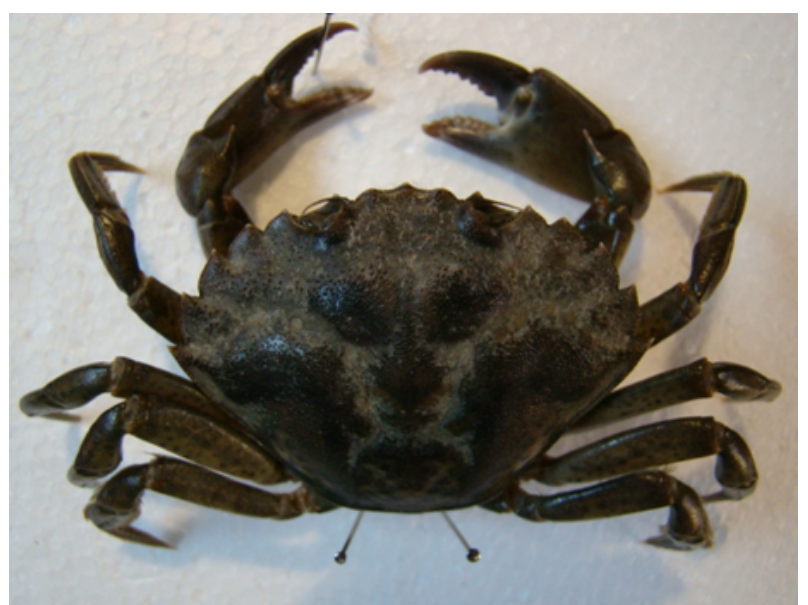

Figura 1. Fotografia de Carcinus maenas em vista dorsal (Ferreira, 2012)

A representação do indivíduo pela técnica do Carbon Dust passou depois por um processo de ensaios gráficos em lápis de grafite que terminaram num desenho preliminar de contorno, à escala (3,2:1), o qual foi transferido, indiretamente, para a folha onde a arte final foi executada (figura 2). O pó de carvão foi produzido abrasando lápis de carvão natural de videira em lixa de água e recolhido em caixa plástica. O pincel seco (pelos de marta Kolinsky, série 7 da Windsor \& Newton) foi depois sujo com este pó, o qual graças às escamas de cada pelo o permitiu transportar para a área a preencher. Na realidade esta técnica simula o princípio técnico da pintura a pincel seco, substituindose a tinta pelo pó de carvão e este é levemente arrastado pela superfície, e em simultâneo o do esfumato da técnica do lápis de grafite (o que permitirá construir paulatinamente gradientes suaves de contraste crescente). O volume que induz a perceção visual de tridimensional é conseguida pela construção e desconstrução (por raspagem ou scratch, com recurso a lâminas) de gradientes monotonais (Froeshner \& Druckenbrod, 2003), sendo que se codifica o branco da superfície de papel como a luz máxima (a guardar) e a sua ausência é dado pelo negro do carvão na expressão máxima (a adicionar, mascarando 
o branco). O efeito é assim conseguido pela dualidade das características do meio que risca e daquele que é riscado.

Em fim último e para reforçar a enfatização da luz foi utilizado um terceiro meio, que permite manter o trabalho anterior intocável, se recorreu à sobreposição de uma película de acetato próprio para inkjet, no qual se reforçam os brilhos por adição do opaco guache branco de titânio e se reforçam as sombras por adição de guache preta (figura 3).

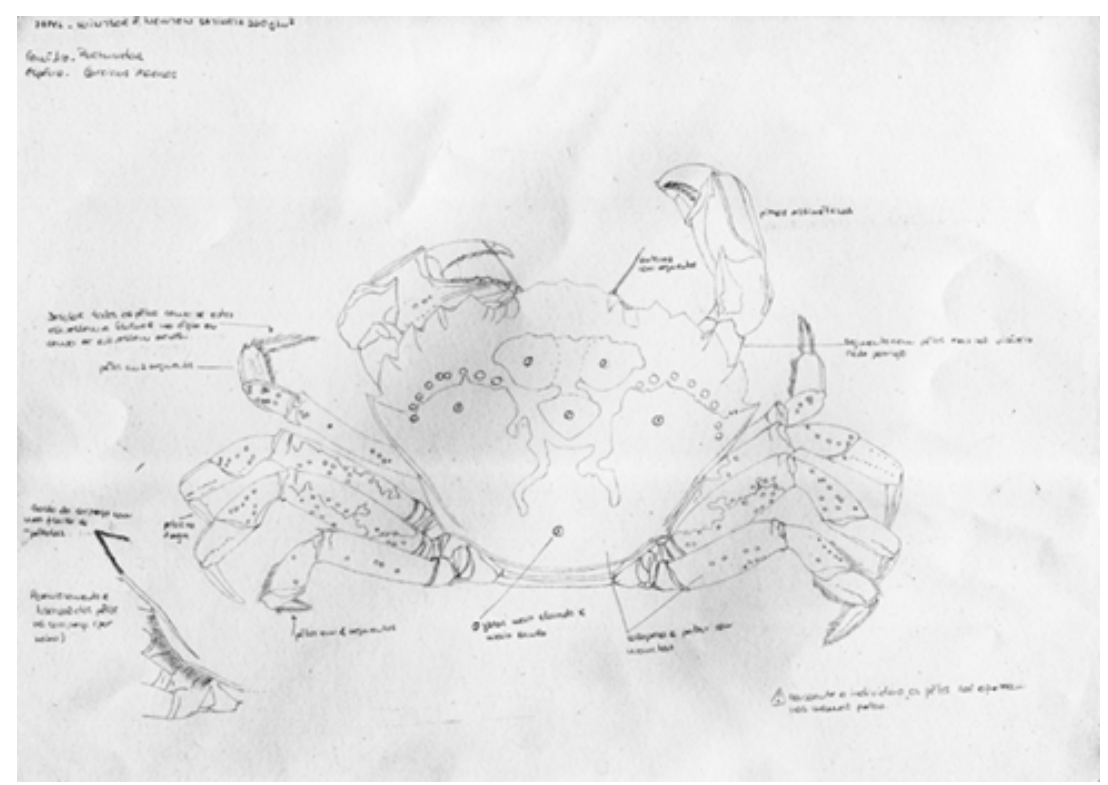

Figura 2. Estudo do espécime e desenho preliminar (Ferreira, 2013) 


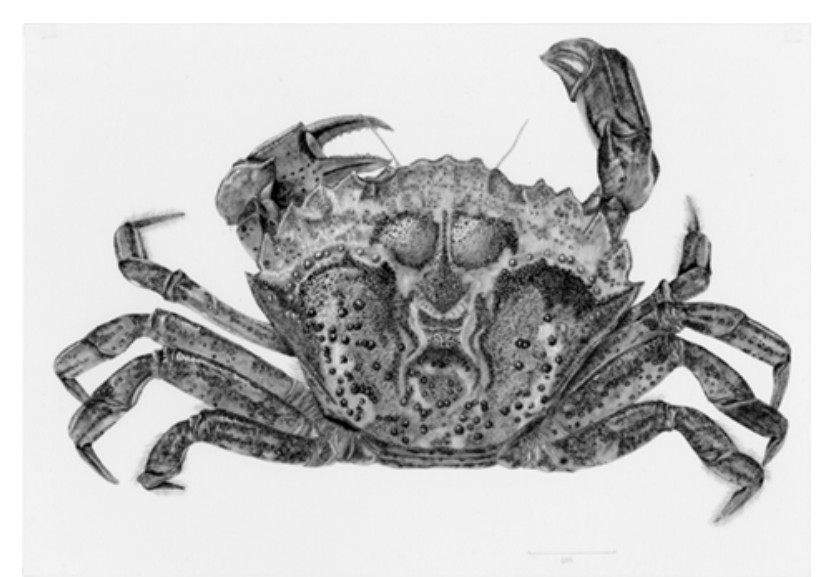

Figura 3. Ilustração final de Carcinus maenas executada em Carbon Dust

(Ferreira, 2013)

Esta técnica flexível permite grandes variações tonais próprias e necessárias a ilustração científica, variando desde uma paleta de cinzas muito claros até ao negro intenso. Relembramos que Max Brödel considerava que a fotografia por si só era insuficiente, observação que o nosso próprio estudo corrobora. O primeiro obstáculo que apresenta a fotografia é que esta apenas fotografa o individuo, o qual pode ser atípico para a espécie, ou não estar na melhor das suas formas (danificado). Por outro lado, o posicionamento da luz aquando da exposição fotográfica pode alterar a percepção da textura (e na leitura desta, sem o exemplar para comparação, uma concavidade pode ser confundida com uma convexidade, por ex.). Assim sendo, existem pressupostos e convenções universalmente adoptados para a ilustração científica que devem ser respeitados, que constituem normas, como seja a orientação da luz (um único foco, com luz incidente migrando do canto superior esquerdo, em diagonal, em direção ao canto inferior direito) que incide no indivíduo. A fotografia apresenta um outro aspeto problemático, a focagem em múltiplos planos, principalmente em objetos de elevado volume: não se consegue recorrendo a uma única fotografia obter, de modo nítido, todos os planos focais (desde a unha das patas ao topo da ornamentação da carapaça, por ex.; atualmente conseguido apenas com focus stacking e sobreposição de várias fotografias do mesmo objeto obtidas com variação da profundidade de campo e 
pós-processamento com software adequados). Esta problemática é facilmente resolvido pela ilustração científica, como os resultados demonstram (figuras 4 e 5).

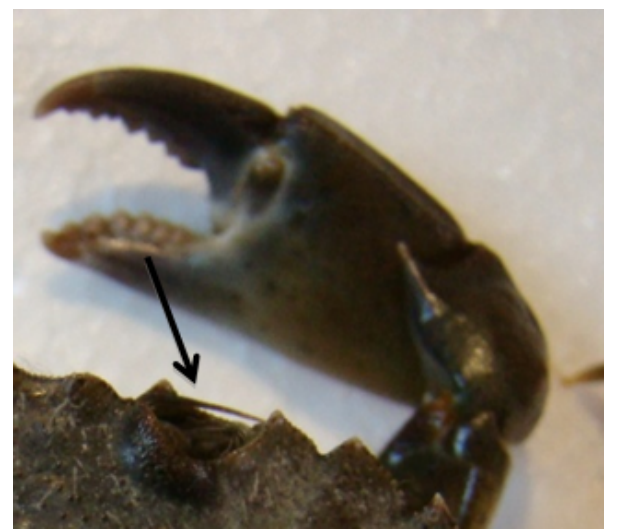

Figura 4. Pormenor fotográfico das antenas e de uma das pinças do espécime que aparece desfocada e em posição post-mortem (Ferreira, 2012)

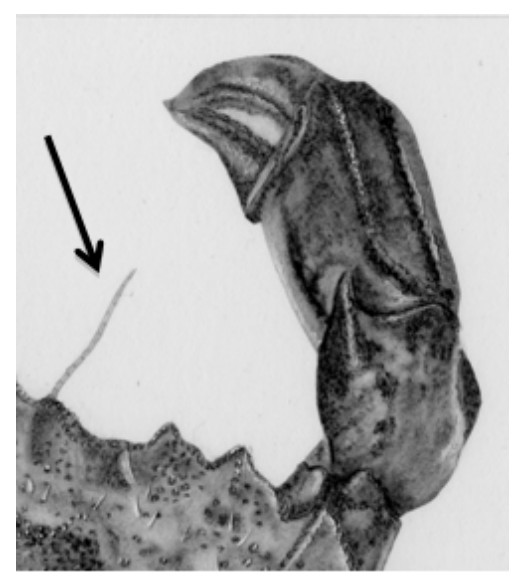

Figura 5. Pormenor ilustrado das antenas recolocadas na sua posição normal e de uma das pinças do espécime (Ferreira, 2013) 
Embora para este trabalho não foram realizadas uma vista ventral e da face do indivíduo, a mesma prancha poderia conter vários pormenores característicos destas faces tais como o aparelho bucal, os olhos ou ainda a forma do abdómen. Se olharmos atentamente a fotografia que segue na figura 6 não se conseguem observar o posicionamento correto das cerdas do animal por este estar fora do seu ambiente natural, a água. No entanto, na ilustração do espécime estes foram desenhados e aparecem nitidamente junto ao corpo e as patas (figura 7). A ilustração das várias especificidades anatómicas, muitas delas reconstruídas e/ou reconfiguradas, e que ainda podem ser mais ou menos enfatizadas através desta metodologia e técnica, justifiquem plenamente a sua utilização preferencial em detrimento da fotografia, uma vez que a ilustração científica tem capacidade de enfoque e elimina ainda todo e qualquer ruído visual que pode ser fator de distração na qualidade da mensagem visual a ser transmitida e assimilada.

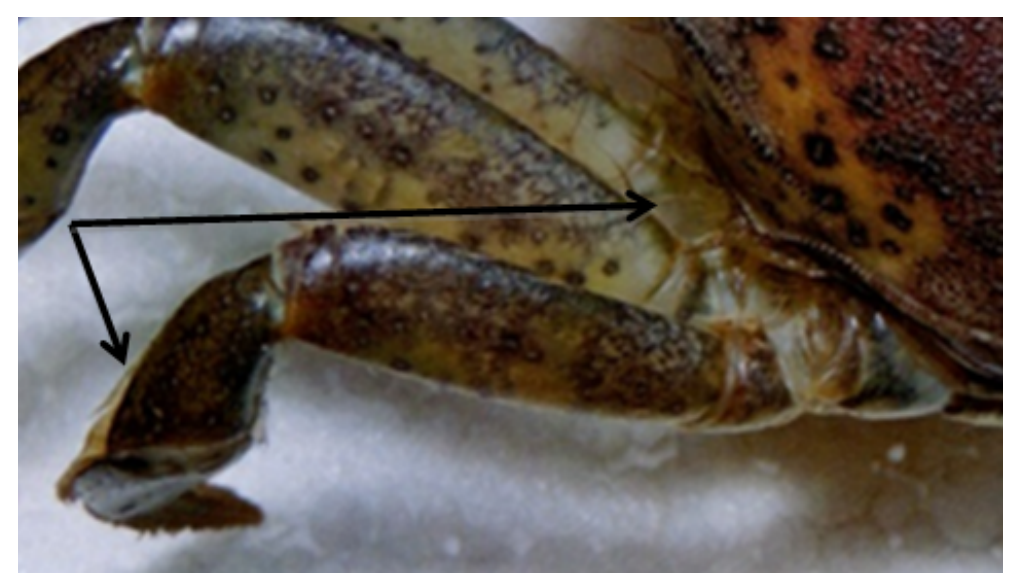

Figura 6. Pormenor fotográfico das cerdas do espécime, afetado pela profundidade de campo, brilhos de reflexão, zonas super- e sub-expostas (Ferreira, 2012) 


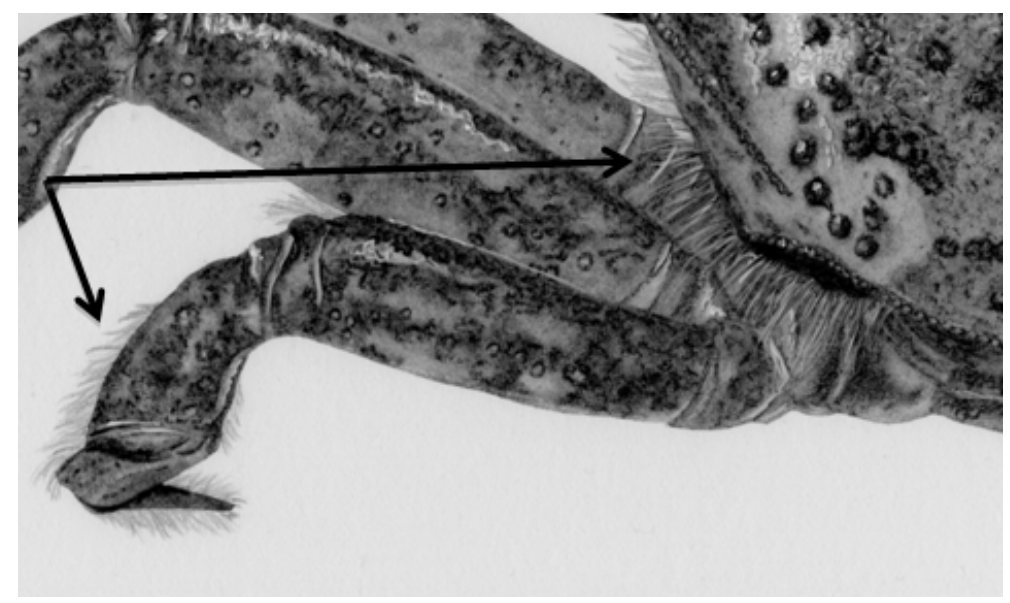

Figura 7. Pormenor ilustrado das cerdas do espécime, com destaque também das articulações, do padrão de superfície e sua textura/ornamentação (Ferreira, 2013)

Mais recentemente o desenvolvimento das técnicas de ilustração digital recorrendo a programas de edição de imagem, tais como Adobe Photoshop, tem permitido igualmente a criação de ilustrações monotonais, importando a metodologia e método de trabalho apreendido nas técnicas clássicas, como a do carvão. Para se conseguirem os mesmo efeitos, a superfície tonalizada homogeneamente de cinzento, pode ser tintada por aplicação direta e variada de tons de cinzento através das ferramentas pincel/aerógrafo/gradiente ou ainda ser escurecida recorrendo à ferramenta "Burn", ou então à ferramenta "Dodge", que clareia as áreas sobre a qual incide (Correia, 2008). Uma não substitui a outra, até porque a técnica clássica pode mimetizar com maior facilidade a textura da superfície externa do espécime, aproveitando a textura do próprio papel traduzida e colocada em evidência pelo depositar do pó de carvão, enquanto nas técnicas digitais se utilizar o APS, toda a textura terá que ser construída ou simulada (muito embora existam programas em que é possível parametrizar as caraterísticas da superfície a pintar - Corel Painter - simulando não só os papéis mas os meios de tintagem e risco clássicos). Poder-se-á ainda dar o caso em que a ilustração iniciada em Carbon Dust, depois de traduzida em bitmaps e importada para uma das aplicações acima referida seja retrabalhada e arte-finalizada em ambiente digital, ou vice-versa, 
conseguindo-se uma muito profícua complementaridade, cheia de potencialidades, assente do desdobrar dos recursos ou ferramentas que pode melhor responder à celeridade com que a informação científica deve ser debitada, sem perder qualidade. Assim, a abordagem mais classicista não se extingue e, muito pelo contrário, integra-se, em plena e bem conseguida adaptação, aos novos tempos e necessidades.

Max Brödel, graças à sua iluminada contribuição, continua como a referência do momento em que Arte entrou e integrou a Medicina, como o veículo essencial para uma melhor comunicação científica dos factos médicos. Ele é uma das provas em como as percepções evoluem e mudam com base nos resultados traduzidos por determinada técnica, cuja pertinência conduz a que a sua validade perdure, evoluindo também, catapultando a comunicação científica, médica, biológica ou outra, para níveis de excelência que melhor respondem às necessidades dos pares científicos, do universo de escolares e da sociedade em geral.

\section{Bibliografia}

Barres, J.M. \& Muñoz, P. (2000). Atlas de Zoologia. Espanha: FGP Editores.

Combier, J. \& Jouves, G. (2014). Nouvelles recherches sur l'identité culturelle et stylistique de la grotte Chauvet et sur sa datation par la méthode du ${ }^{14}$ C. L'anthropologie, 118: 115-151.

Correia, F. (2008a). Reciclar - do velho fazer novo. Advanced Photoshop (A)PS Arte Digital, 11: 31-34.

Correia, F. (2009a). Ilustração Científica - desenhar o saber e o saber do desenho. Biologia \& Sociedade, 8: 39-41.

Correia, F. (2010). Ilustração Científica em Portugal - a génese e o ensino. Anais do III Encontro Nacional de Ilustradores Científicos: Ed. em Pdf/CD (pp. 14-35). Brasília, Brasil: Associação dos Ilustradores Científicos do Centro-Oeste Brasileiro.

Correia, F. (2011a). A Ilustração Científica - "santuário" onde a Arte e a Ciência comungam. Visualidades, 9/2: 221-239.

Correia, F. (2011b). Ilustração Científica - imagem sobre (-o-) natural. Parques e Vida Selvagem, 35: 45-47. 
Correia, F. (2011c). Retratos Naturais - Vamos desenhar... um pardal. Parques e Vida Selvagem, 35: 48-49.

Correia, F. (2012). Retratos Naturais - Vamos desenhar... um grilo. Parques e Vida Selvagem, 38: 50-51.

Correia, F.J. \& Ismar, C. (2015). Paleoarte. Brasil: (in publication).

Czegledy, N. (2010). Women at the threshold of art and medicine. Comunicado do Congresso Internacional Mujer, Arte y Tecnología en la Nueva EsferaPública. Retrieved from www.upv.es. Valéncia, Espanha: Universidade Politècnica de València.

Froeshner, E.H. \& Druckenbrod, L.M. (2003). The Guild Handbook of Scientific Illustration. In E. Hodges, S. Buchanan, J. Cody \& T. Nicholson (Eds.), Carbon Dust (pp. 151-160). New Jersey, NJ: John Wiley \& Sons, Inc.

Saldanha, L. (2003). Fauna Submarina Atlântica - Portugal continental. Açores. Madeira. Mem Martins, Portugal: Publicações Europa-América.

Shultheiss, D. \& Jonas, U. (1999). Max Brödel (1870-1941) and Howard Kelly (1858-1943) - Urogynecology and the birth of modern medical illustration. European Journal of Obstetric \& Gynecology and Reproductive Biology, 86: 113-115.

Shultheiss, D.; Engel, R.M.; Crosby, R.W.; Lees, G.P.; Truss, M.C. \& Jonas, U. (2000). Max Brödel (1870-1941) and medical illustration in urology. The Journal of Urology, 166: 1137-1142.

Stanyer, P.W. (2003). The Complete Book of Drawing Techniques - a professional guide for the artist. In P.W. Stanyer, Charcoal-Charcoal, Conte e Crayons and Compressed Charcoal (pp. 80-140). London, L: Arcturus Publishing Ltd. 
$\bigoplus$

$\bigoplus$

$\oplus$ 


\title{
Comunicação da ciência e mobilização ou "quanto vale a água"?
}

\author{
Adriana Bravin \\ Universidade Federal de Minas Gerais / Universidade do Minho / Capes \\ E-mail: adriana.bravinegmail.com
}

\begin{abstract}
Resumo
Como movimentos ambientalistas atuam para mobilizar a opinião pública em defesa de suas causas, utilizando-se da comunicação da ciência? Como transformam informação e conhecimento científico em recursos para pressionar as decisões políticas que visem a preservação do meio ambiente e melhoria da vida dos cidadãos? Este artigo discute esses termos e essa forma de mobilização, a partir da experiência do Movimento Pela Preservação da Serra do Gandarela (MPSG), na Região Metropolitana de Belo Horizonte $(\mathrm{RMBH})$, capital de Minas Gerais, Brasil, zona historicamente explorada pela mineração de ferro e onde se concentram diversos conflitos ambientais gerados por essa atividade. Ao difundir o conhecimento científico para públicos

não-especialistas sobre a importância da Serra do Gandarela e suas nascentes para a RMBH, uma vez que a área é alvo de interesse da segunda maior mineradora do mundo, o MPSG apresenta novos campos problemáticos, de redefinição dos contornos de objetos e seu sentido econômico, social, político, ambiental e simbólico. Procuramos observar os modos de mobilização e comunicação da ciência pelo MPSG a partir de três elementos que se configuram centrais em suas narrativas: 1) a ênfase na defesa do potencial hídrico da Serra do Gandarela, ameaçada pela mineração; 2) o uso de pesquisas científicas para certificar essa defesa; 3) a escassez de água no presente como resultante da má-gestão desse recurso, no passado, no Brasil.
\end{abstract}

Palavras-chave: movimento ambiental; comunicação da ciência; mobilização; água.

\begin{abstract}
How environmental movements act trocauses? How do they turn change scienugh science communication in order to tific information and knowledge into remobilize public opinion to support their sources to pressure political decisions re-
\end{abstract}


garding the preservation of the environment and the improvement of people's life? This paper discusses those topics based on the "Movimento Pela Preservação da Serra do Gandarela (MPSG)" movement, situated on Belo Horizonte's surroundings (RMBH), capital of Minas Gerais, Brazil; historical area explored by mining companies where many environmental conflicts take place. By broadcasting scientific knowledge regarding Gandarela's hill and its springs to the non specialized public on Belo Horizonte's surroundings, the MPSG re-signify the region's economic, social, political, en- vironmental, and its symbolic meaning, since the area is of interest to the second largest mining company in the world. We sought to observe ways in which the MPSG mobilizes as well as communicates science on its newspaper, website in which three elements are of high importance: 1) the emphases on defending Gandarela's hill's hydric potential which is threatened by mining; 2) the use of scientific research in order to validate their defense; 3) the current situation that highlights todays lake of water and predicts hydric insecurity for the future due to Brazil's mismanagement.

Keywords: environment movement; science communication; mobilization; water.

\section{O que, como e por que dizer Ciência?}

que nos referimos quando falamos em Comunicação Pública da Ciên-
para que/quem e com que objetivo? Falamos disso somente quando somos
"alvo" de aprendizagem em museus interativos, na escola, ou quando somos
bombardeados por informações sobre curiosidades e descobertas do mundo
da ciência via meios de comunicação? A literatura sobre o tema considera
este modelo ${ }^{1}$ superado já que, como argumenta Castelfranchi (2008; 2010),
a comunicação da ciência e o funcionamento da tecnociência na sociedade
globalizada operam por uma "complexa rede de osmoses e fluxos de infor-
mação científica" (Castelfranchi, 2008, p. 11), em processos de comunica-
ção multidirecionais e transversais. Falar em linguagem especializada e não-
especializada tem menos efeito que saber por que, o que e como comunicar
com não-especialistas.

1. No modelo do deficit, o público é alimentado com o "saber científico" mediado por especialistas, em um fluxo unidirecional de informação. 
Segundo este autor, mais do que um dever, comunicar ciência tornou-se uma necessidade. Seja para que pesquisadores promovam a visibilidade das pesquisas, e ganhem apoio para seus financiamentos. Seja para o exercício da cidadania, pois "cada vez mais (o cidadão) quer saber, precisa saber, estar conectado com o fluxo de informação e de debates que têm por centro de gravidade a tecnociência, seja para exercer uma cidadania plena ou para sua carreira e vida pessoal". (Castelfranchi, 2010, p.19).

Assim, empoderamento é a palavra-chave na compreensão pública da ciência, a partir do modelo do engajamento (Villegas, 2013), uma vez que a participação cidadã, em tomadas de decisões sobre temas importantes que dizem da vida em sociedade e que impactam o cotidiano de múltiplas formas, demanda trânsitos de saberes e de práticas na constituição de instâncias de difusão do conhecimento científico. Espaços, que promovam tanto a produção quanto a circulação de informações de maneira contextualizada, aprofundada e dialógica.

Dessa maneira, acreditamos que transformar a informação e o conhecimento gerado de/a partir da ciência em ações práticas, que levem a mudanças de atitudes individuais/coletivas, a mobilização social e a formas de participação na gestão de interesses da coletividade, como os recursos naturais, constitui-se também um modo de difusão e popularização da ciência. É assim que movimentos sociais vêm favorecendo a capilaridade e transversalidade do fazer ciência na sociedade globalizada, tanto nas instâncias de interlocução para avaliar, gerir, difundir e financiar pesquisas quanto nas de produção desse conhecimento (Castelfranchi, 2010).

É nesse sentido que irei argumentar, a partir de um recorte sobre a pesquisa em andamento no doutorado, a respeito das narrativas identitárias (Ricoeur, 1991) do Movimento Pela Preservação da Serra do Gandarela (MPSG). Há sete anos, esse coletivo atua na resistência às tentativas de um megaempreendimento minerador se instalar em uma área de recarga de água próxima à terceira maior região metropolitana do Brasil. Irei discutir como esta organização se apropria do conhecimento científico como recurso e adota uma linguagem de valoração da água, no trânsito entre termos das ciências ambientais e conceitos advindos dos movimentos globais de Justiça Ambiental (Martinez-Alier et al, 2014), em uma dupla visada: 1) na produção e difusão científica que corroborem sua luta em defesa do Gandarela e de suas nascen- 
tes; 2) junto às instâncias políticas, pressionando por mais participação cidadã em decisões que envolvam o meio ambiente e a gestão de recursos naturais.

\section{A serra, o movimento e a mineração}

Para responder as indagações sobre o "como", "por quê" e "o que" diz o MPSG em suas narrativas, entre determinadas compreensões da ciência e suas construções interpretativas, é preciso partir de um de seus começos, pois narrativas podem ter diferentes inícios possíveis (Ricoeur, 1991). Comecemos pelo motivo ou objeto do conflito ambiental que constitui o grupo para compreendermos sua ação e suas "formas" de dizer ciência.

O MPSG aglutina diversos coletivos e indivíduos para impedir atividades de uma gigante da mineração na Serra do Gandarela. Essa montanha abrange quatro dos oito municípios que integram a Região Metropolitana de Belo Horizonte (RMBH), a terceira maior do país, com cerca de 5 milhões de habitantes, localizada em Minas Gerais. Distante a $40 \mathrm{~km}$ da capital, a Gandarela é uma das vertentes da região conhecida como "Quadrilátero Ferrífero", uma das principais produtoras de minério de ferro do mundo, e também integra a Reserva da Biosfera do Espinhaço, uma unidade de conservação federal, mas que só possui $27 \%$ de sua área sob proteção.

A exploração mineral no "Quadrilátero" começou com a extração do ouro em meados do século XVII. Outros tipos de rochas e minerais também são explorados atualmente, como topázio e bauxita. Além disso, vem se destacando também a grande presença de empreendimentos imobiliários (Lamounier, 2009). Há, portanto, uma relação de dependência econômica da mineração nessa região e em Minas Gerais.

E por que exatamente a Serra do Gandarela interessa à mineradora? Primeiro porque ainda não foi explorada e guarda uma quantidade impressionante de minério; segundo, por conta da qualidade do mineral ali estocado ser de alto valor para o mercado de comodities. Os números do projeto da mina Apolo que a mineradora quer implantar são grandiosos: U\$ 2,4 bilhões para produzir cerca de 24 milhões de toneladas de minério/ano, inicialmente durante 35 anos. Para tanto, seriam ocupados 6 mil hectares dessa Serra. Pelas dimensões, a mina Apolo ficaria atrás apenas de Carajás, a maior de extração de minério de ferro a céu aberto no Brasil. 
É essa ameaça que mobiliza o MPSG em uma reação ao projeto minerador, antecipando-se aos danos e agindo no sentido de impedir sua efetivação. Para isso, há sete anos evidencia os riscos e futuras perdas ambientais, e pressiona os poderes públicos pelos limites à atividade minerária. Uma das primeiras ações foi a publicização dos pedidos de licença ambiental feitos há cinco anos pela empresa mineradora.

Mas, como se contrapor à mineração em uma região historicamente dependente dessa atividade? Como argumentar em favor de recursos naturais diante de uma empresa que os explora mundo afora e da força de um discurso conectado ao desenvolvimentismo governamental? Por que falar em defesa de uma montanha, localizada em um dos principais epicentros da exploração mineral do Brasil? Que atributos fazem desse espaço alvo de interesse dos ambientalistas? O que isso tudo tem a ver com difusão da ciência?

\section{A gramática da defesa ou "como isso populariza a ciência?"}

Para responder essas questões, partimos de nossa observação participante, do monitoramento das ações do grupo nos últimos dois anos e de análise preliminar da produção de seu material informativo e promocional (de cartazes a fôlderes, panfletos, jornal impresso, sítio na Internet, perfil no Facebook, vídeos no Youtube, documentos, além de material de apoio, como reportagens e entrevistas em TVs e rádios) ${ }^{2}$.

Orientamos nosso olhar a respeito dos modos como o MPSG faz uso da informação científica como recurso para a defesa da Serra e de suas águas. Nos concentramos na seleção de narrativas que informam sobre apropriação/difusão do conhecimento científico como um modo de mobilizar para a defesa da Serra e de ampliar o escopo de participação pública nas decisões sobre a montanha ${ }^{3}$.

Observamos que tanto para mobilizar a opinião pública, promover o assunto "Gandarela" na imprensa, quanto para empoderar o grupo e promover o engajamento por maior participação nas decisões sobre o futuro da região foi preciso encontrar uma "gramática", com simbologia, termos, heurística e

2. O material coletado faz parte do acervo da pesquisa em curso no doutoramento.

3. A seleção contemplou materiais veiculados nas edições do jornal O Gandarela (entre 2012 e 2014), no sítio do grupo na Internet, e em entrevista de um de seus integrantes à TV pública Rede Minas. 
seus próprios modos de dizer sobre a montanha e o conflito nela instalado. Modos que provocassem novos sentidos para a "montanha-de-minério" e justificassem a urgência no pedido para a criação do Parque Nacional da Serra do Gandarela ${ }^{4}$.

Essa gramática, que aqui chamarei de "gramática da defesa", se apropria de/e difunde termos científicos para ressignificar o "Quadrilárero", onde se localiza a montanha, de "ferrífero" para "aquífero", como mostra a Figura 1. Outros termos vindos das ciências biológicas e ambientais, como "vegetação de cangas", "campos ferruginosos", "campos rupestres", "cavernas em canga", "paleotoca", "recarga de aquíferos", "alvo guarda-chuva", "geossistema canga/itabirito", "águas de Classe 1" são apropriados e didaticamente explicados e relacionados aos "atributos" da Serra.

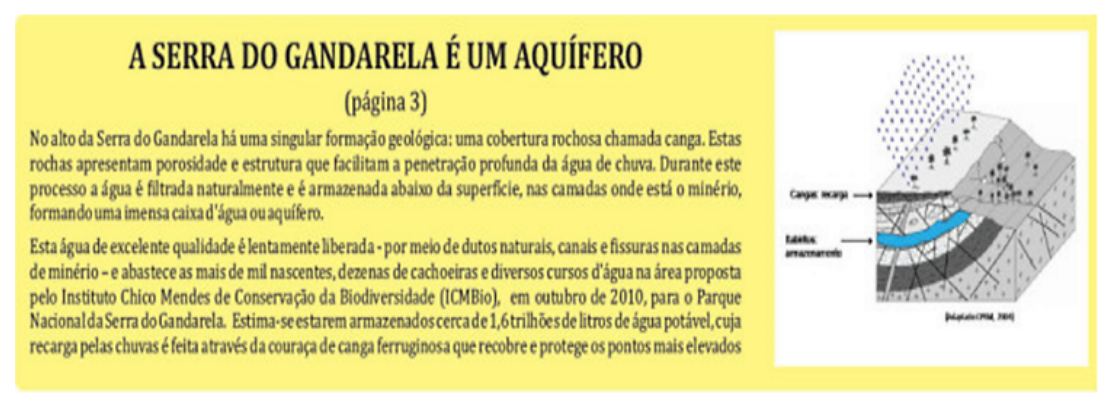

Figura 1. Chamada na capa do jornal O Gandarela (2014, janeiro), n.4, p.1

O uso de ilustrações, como indicado acima, também narra sobre aquilo que é invisível aos olhos ao apresentar, didaticamente, a relação água-minério e provocar o debate sobre o impacto da mineração sobre os recursos hídricos, especialmente em função de determinada formação geológica daquela Serra e região mineira. Pesquisadores se unem aos esforços dos ambientalistas numa co-produção de conhecimento científico (Castelfranchi, 2010) e colaboram para popularizar a intrínseca relação canga-formações ferríferaságua, conforme demonstra a ilustração (Figura 1). Encontramos exemplos da circulação dessa narrativa no projeto para a criação do Parque do Gandarela (Instituto Chico Mendes para a Biodiversidade (ICM-Bio), 2010), em publi-

4. Recuperado a partir de http://pesquisa.in.gov.br 
cação sobre conflitos minerários do país (Fernandes, Alamino and Araújo, 2014) e em reportagens sobre o tema.

Outro exemplo de popularização da ciência como forma de mobilização é a entrevista do ambientalista e geólogo, Paulo Rodrigues, integrante do Movimento Gandarela, a um canal público de televisão. O pesquisador é convocado a falar sobre a crise hídrica no país e em Minas e reflete sobre o conflito água versus mineração.

Temos aqui um grande quadrilátero ferrífero que é também um aquífero. Só que temos uma coincidência pouco vantajosa. É que a camada de ferro, que dá o nome ao Quadrilátero Ferrífero, é também a camada onde a água fica armazenada. Aonde se minera o ferro, aquela camada que é uma caixa d'água subterrânea, desaparece também. (...) Se olharmos a região do Quadrilátero, já está toda sendo explorada pela mineração de Ferro. O único lugar ainda intacto é a Serra do Gandarela. Mas o que a Serra tem a ver com a nossa água? Tem por conta do que eu já falei e o aquífero principal do Quadrilátero Ferrífero é onde está o minério de ferro. Temos de pensar muito bem: se for minerar o ferro, vamos perder os nossos aquíferos (Rodrigues, Paulo). ${ }^{5}$

A seguir, a Figura 2 nos fornece mais uma dimensão do que nos dizem as narrativas sobre água enquanto "valor", agora, por meio de mapa produzido a partir de imagem por satélite que informa sobre a dimensão da rede de drenagem da Gandarela, formada por mais de mil nascentes. O perímetro desenhado refere-se à proposta do MPSG para a criação do Parque Nacional, que não se efetivou como os ambientalistas reivindicavam.

5. Entrevista Paulo Rodrigues ao Programa Opinião Minas, Rede Minas de TV, em 02/03/2015. Recuperado a partir de: www.youtube.com (parte 1) 


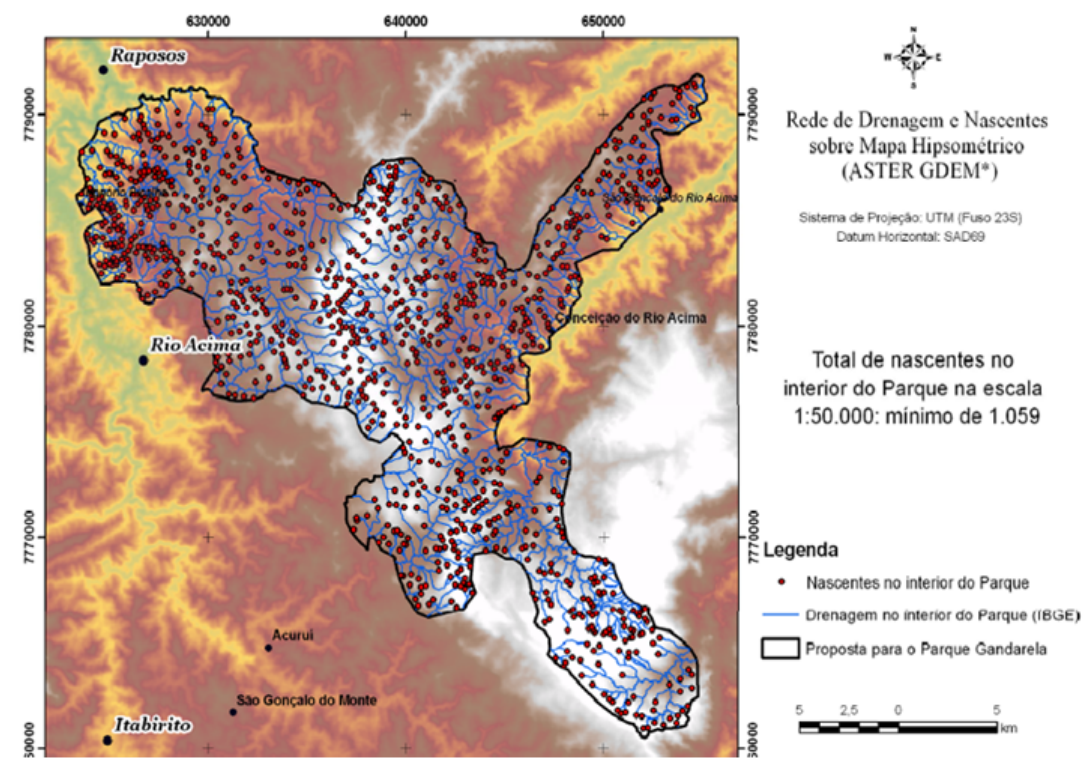

Figura 2: mapa da rede de drenagem e nascentes da Serra do Gandarela. Recuperado a partir de: www.aguasdogandarela.org

Responder à pergunta "por que a Serra do Gandarela é importante para a "segurança hídrica" de Belo Horizonte e região?" adquire um tom de alerta nas Figuras 3 e 4, ao possibilitarem a visualização da dimensão do problema envolvendo qualidade das águas, comunidades e abastecimento de uma região populosa. Os mapas (Figura 3) narram os caminhos das "águas limpas", suas ligações com a formação das bacias dos rios que abastecem a região e com as estações de captação. O texto relaciona o "aquífero" e suas águas "especiais", à dependência da captação nos rios que formam essa bacia hidrográfica e que fornecem água para Belo Horizonte e seu entorno.

$\mathrm{Na}$ tabela (Figura 4), por sua vez, a narrativa é complementada com os números que informam o percentual de dependência de quatro municípios no entorno da Serra, entre eles, a capital Belo Horizonte, em relação ao Sistema Integrado (SIN) de abastecimento do Rio das Velhas, localizado em uma das faces do Gandarela. As narrativas apontam para o leitor a quem se dirigem, o morador da região metropolitana, mas também para os gestores do sistema 
ambiental e legisladores. Isto porque, em abril de 2015, o Instituto Mineiro de Gestão das Águas (IGAM) declarou escassez hídrica em três regiões hidrográficas da $\mathrm{RMBH}^{6}$.

Essas formas de valorar a água conectam-se aos debates sobre a importância desse recurso como um direito humano, no âmbito dos movimentos de Justiça Ambiental global, conforme Martinez-Alier et al (2014), e procuram engajar o tema na vida cotidiana da população que será diretamente atingida, caso o projeto minerador se concretize. Outros conceitos, como "sustentabilidade", "economia familiar", "passivo ambiental", "biodiversidade", "segurança hídrica" que circulam em diversas narrativas do movimento procuram justificar a defesa integral da Serra e suas nascentes com a criação de um Parque, apresentado como alternativa de desenvolvimento sustentado para a região.

6. www.igam.mg.gov.br, publicado em 09/04/2015 


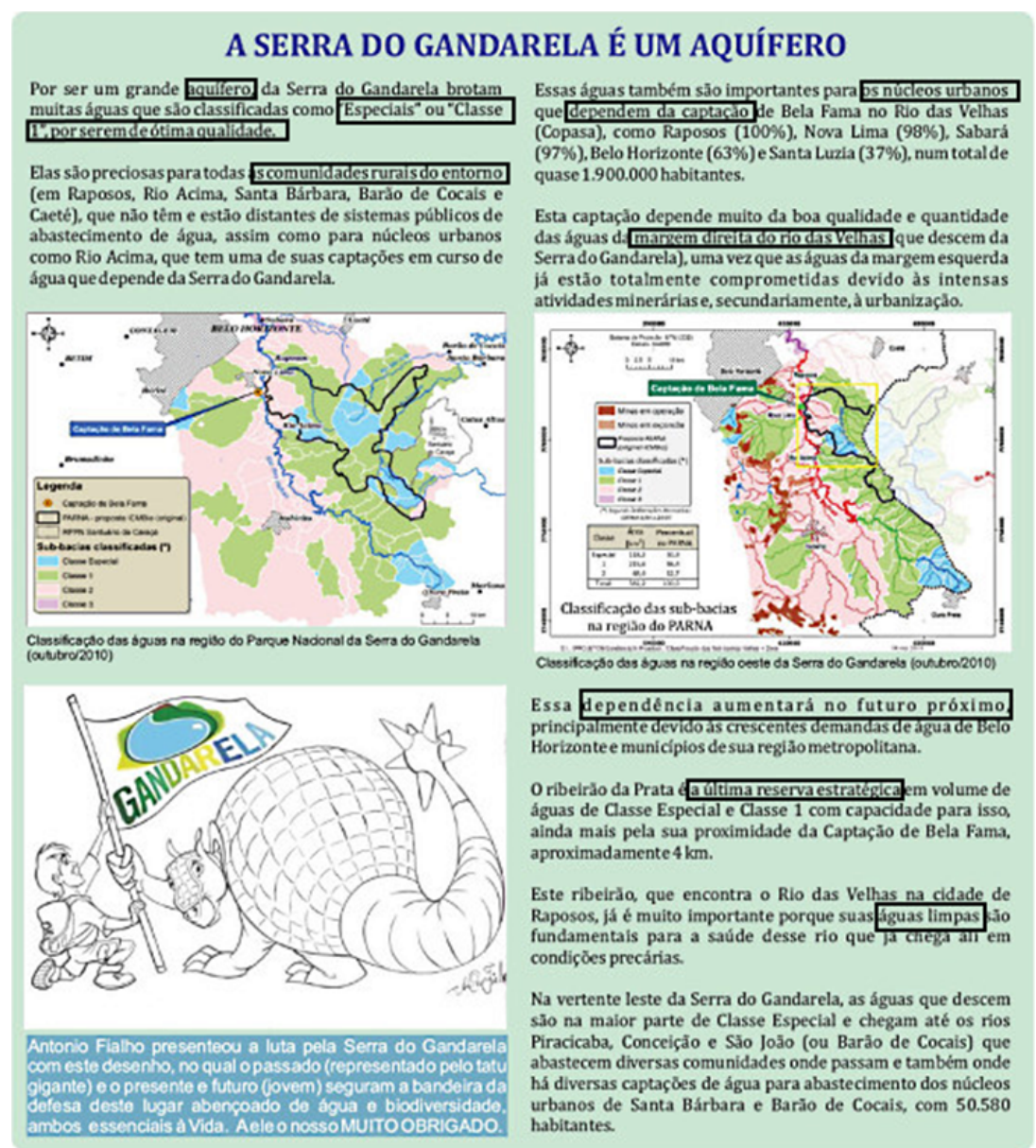

Figura 3. Jornal O Gandarela (2014, janeiro) n. 4, p. 4 


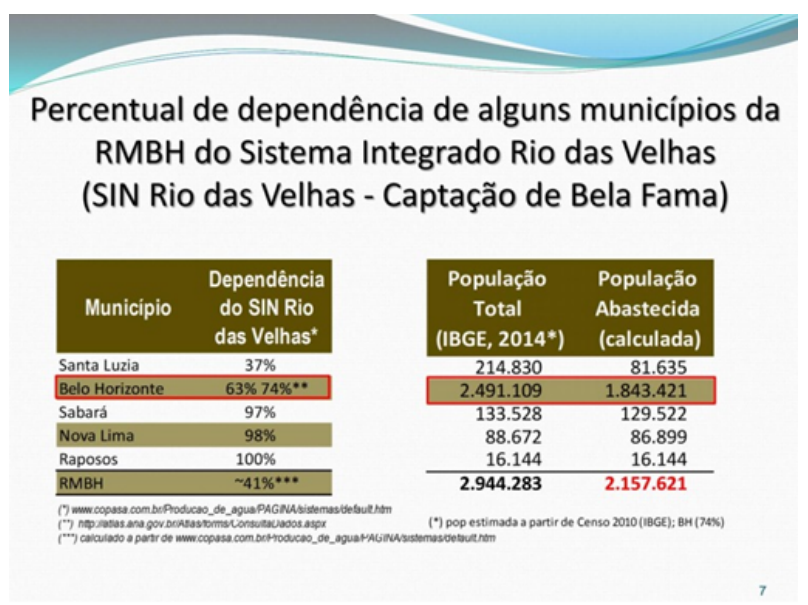

Figura 4: tabela apresentada pelo Movimento Gandarela à diretoria da Copasa, companhia de abastecimento de água de Minas Gerais. Recuperado a partir de: www.aguasdogandarela.org

\section{Considerações sobre empoderamento e engajamento via ciência}

A gramática da defesa do Gandarela é suficiente para promover o engajamento e ampliar o escopo de participação na gestão dos recursos naturais? Que resultados foram alcançados por meio dessa ação narrativa apoiada em conhecimento científico que, no entanto, não se esgotou? Empoderar os sujeitos da ação coletiva como forma de pressionar por medidas justas em relação ao quadro apresentado aparece como primeiro resultado.

Saber o que, por que e como comunicar, a partir da co-produção científica (Castelfranchi, 2010) e do trânsito de conceitos (Martinez-Alier et al, 2014) tem se mostrado eficiente enquanto recurso para qualificar os sujeitos tanto para o debate sobre segurança hídrica quanto para propor transformações nos modelos de desenvolvimento visando essa finalidade. Isto ficou evidente quando o MPSG formulou uma proposta para a criação do Parque Nacional do Gandarela, incluindo a criação de áreas destinadas a Reservas de Desenvolvimento Sustentável (RDS), onde as populações tradicionais do entorno do futuro Parque teriam garantidos seus modos de subsistência ligados à natureza 
e seu uso sustentado. A criação desta unidade de conservação, em 31 de outubro de 2014, não encerra essa trama, uma vez que a própria Serra, alvo da mineração, ficou fora dos limites do Parque. Novas narrativas e estratégias serão tecidas.

A informação aprofundada e de qualidade pode levar à participação, seja como consumidores, seja como cidadãos, "em tomadas de decisões sobre temas importantes e tão variados como transporte, tratamento de lixo, drogas, políticas sanitárias, experimentações médicas, comida transgênica, pesticidas, usinas hidrelétricas e nucleares, gestão das áreas indígenas, manejo florestal e inúmeras outras". (Castelfranchi, 2010, p. 14). Pode levar ao engajamento em ações coletivas como a empreendida pelo Movimento, que se autoengaja em seu papel cidadão ao "fazer um alerta à Copasa, sobre a importância da preservação da região da Serra do Gandarela para o abastecimento de água, não só da Região Metropolitana de Belo Horizonte como dos municípios de Barão de Cocais e Santa Bárbara, onde a concessionária também é responsável pelo abastecimento" 7 .

A ousadia do engajar-se, aqui, é fazer-se ser ouvido pela própria companhia gestora do abastecimento da região metropolitana e ter sua opinião considerada. Dizer o que tem que ser dito. Do mesmo modo, discutiu os limites do então futuro Parque do Gandarela com a ministra do Meio Ambiente, debateu com o Ministério Público ações para impedir o início das operações na mina Apolo, participou do Grupo de Trabalho (GT) Gandarela, criado pela Secretaria de Meio Ambiente de Minas para elaborar uma proposta de consenso sobre o projeto de criação do Parque.

Antes da aprovação final da proposta, o Movimento angariou apoio popular à criação do Parque por meio de petições on-line, abaixos-assinado, campanhas na Internet, adesão de outras entidades, eventos, exposições sobre o Gandarela. O empoderamento dos sujeitos coletivos como defendemos aqui, no trânsito entre diferentes saberes, se efetiva, ainda, à medida que fazem-se responsáveis pela ocorrência das transformações que a comunicação da ciência possibilita. Como afirma Villegas (2013, p. 1565), "una comunicación de la ciencia 'exitosa' debiera permitir a los agentes ser parte de las decisiones

7. Alerta publicado na página do Movimento Gandarela na Internet, recuperado a partir de: www.aguasdogandarela.org 
sobre dichas transformaciones y hacerse responsables por ello". Não seria esse, afinal, um nobre objetivo da difusão da ciência?

\section{Referências}

Castelfranchi, Y. (2008). Para além da tradução: o jornalismo científico crítico na teoria e na prática. Los desafios y la evaluación del periodismo cientifico em Iberomerica: Jornadas Iberoamericanas sobre la ciencia em los medios massivos. Santa Cruz de la Sierra (Bolívia): AECI, RICYT, CYTED, SciDevNet, OEA.

Castelfranchi, Y. (2010). Por que comunicar temas de ciência e tecnologia ao público? (Muitas respostas óbvias... mais uma necessária). Jornalismo e ciência: uma perspectiva ibero-americana. Rio de Janeiro: Fiocruz / COC / Museu da Vida.

Fernandes, F.; Alamino, R. \& Araujo, E. (Eds). (2014). Recursos minerais e comunidade: impactos humanos, sociomabientais e econômicos. Rio de Janeiro: CETEM/MCTI.

Instituto Chico Mendes para a Biodiversidade (ICM-Bio). (2010, setembro). Proposta para a criação do Parque Nacional da Serra do Gandarela. Ministério do Meio Ambiente; ICM-Bio. Recuperado a partir de: www.icmbio.gov.br

Lamounier, W.M. (2009). Patrimônio natural da Serra do Gandarela e seu entorno: análise ambiental como subsídio para a criação de unidades de conservação no Quadrilátero Ferrífero - Minas Gerais. (Dissertação de mestrado). Instituto de Geociências/ Universidade Federal de Minas Gerais, Belo Horizonte, Brasil.

Martinez-Alier, J.; Anguelovski, I.; Bond, P.; Del Bene, D.; Demaria, F.; Gerber, J.-F.; Greyl, L.; Haas, W.; Healy, H.; Marín-Burgos, V.; Ojo, G.; Porto, M.; Rijnhout, L.; Rodríguez-Labajos, B.; Spangenberg, J.; Temper, L.; Warlenius, R. \& Yánez, I. (2014). Between activism and science: grassroots concepts for sustainability coined by Environmental Justice Organizations. Journal of Political Ecology, 21: 19-60. Recuperado a partir de: http://jpe.library.arizona.edu

Ricouer, P. (1991). O si-mesmo como um outro. Campinas: Papirus. 
Villegas, A.G. (2013). La búsqueda de diálogos a través de la comunicación pública de la ciência. Memorias de la XIII Reunión de la Red de Popularización de la Ciencia y la Técnica en América Latina y el Caribe - XIX Congreso Nacional de Divulgación de la Ciencia y la Técnica. México: SOMEDICyT. 


\title{
Sistema de revisão por pares na ciência: o caso de revistas científicas do Brasil, da Espanha e do México
}

\author{
Cláudio N. N. Silva, Murilo A. A. Silveira \& Suzana P. M. Mueller \\ Inst. Federal de Brasília / Univ. Federal de Pernambuco / Univ. de Brasília \\ E-mail: claudio.silva@ifb.edu.br/muriloas@gmail.com / \\ suzanapmmegmail.com
}

\begin{abstract}
Resumo
Apresenta as modalidades de revisão por pares praticadas por periódicos científicos mais qualificados no Brasil, na Espanha e no México. Discute essas modalidades, com ênfase em quatro áreas do conhecimento: Ciências da Vida, Ciências Puras, Ciências Sociais e Humanidades. De caráter exploratório, a pesquisa utilizou-se da opinião dos editores dos periódicos dos três países contemplados sobre as práticas avaliativas conduzi-

das na revisão de originais. Os principais resultados são: a) práticas de avaliação semelhantes entre os periódicos científicos dos três países pelas quatro áreas do conhecimento; e b) práticas de avaliação plurais nas Ciências Puras em relação aos países investigados. Conclui que as modalidades de revisão por pares são regulares e semelhantes nos três países, mas sinalizam sensíveis diferenças quando se referem às áreas do conhecimento.
\end{abstract}

Palavras-chave: Periódicos científicos; revisão por pares; Brasil; Espanha; México.

\begin{abstract}
It presents the modalities of peer review practiced by the most qualified scientific journals in Brazil, Spain and Mexico. It discusses these methods, focusing on four areas of knowledge: Life Sciences, Pure Sciences, Social Sciences and Humanities. The research, exploratory, analyzed opinions of these high ranked journals produced in each of the three countries, focusing on evaluation practi-

ces of submitted papers. Main results are: a) the four subject areas hold similar evaluation practices in the three countries. b) Considering the four areas, Pure Sciences present the most varied practices, despite the country. It concludes that peer review modalities are regularly practiced and are similar in the three countries, but indicates significant differences among areas of knowledge.
\end{abstract}


Keywords: Scientific journals; peer review; Brazil; Spain; Mexico.

\section{Introdução}

To domínio da Comunicação Científica, os estudos sobre avaliação de re1 vistas científicas compreendem múltiplas possibilidades de investigação, destacando-se o processo de revisão pelos pares como uma das vertentes. Tal perspectiva evidencia a relação entre os integrantes, as posições que exercem e as decisões que tomam, formatando o fluxo concernente às atividades que compõem o processo. Do momento da submissão até à publicação (ou rejeição), autores, revisores e editores realizam suas funções editoriais com base em preceitos e normas de conduta, assim como em noções de conhecimento que constituem a dinâmica do campo científico (Stumpf, 2005). O panorama descrito se insere, deste modo, na lógica da cadeia produtiva do conhecimento científico, sustentado por estes atores científicos que estabelecem a configuração da revisão pelos pares como um sistema.

A literatura especializada define três sistemas de revisão por pares (peer review) na ciência: duplo cego, simples cego e aberto. O sistema duplo cego (double blind peer review) é caracterizado pelo anonimato entre autores e revisores. O sistema simples cego (single blind peer review) é aquele em que autores são conhecidos dos revisores, mas revisores permanecem anônimos para os autores. E, por fim, o sistema aberto (open peer review) é aquele em que tanto autores quanto revisores conhecem a identidade um do outro (Pavan; Stumpf, 2009). As autoras também enfatizam que a determinação para a escolha do sistema de revisão por pares varia de acordo com as formas de disseminação do conhecimento legitimado pelos campos científicos.

A amplitude de possibilidades para estudo do sistema de revisão por pares em periódicos científicos é desafiante, na medida em que aspectos psicológicos, sociológicos, políticos, históricos e éticos, isolados ou conjuntamente, influenciam as atividades de avaliação e as formas de divulgação nas ciências. Desses aspectos decorrem a homogeneização e cristalização das práticas avaliativas nos níveis institucionais, geográficos e temáticos em âmbito local, regional, nacional e internacional. Contudo, admite-se que tais imperativos sinalizam o consenso acordado entre os praticantes da ciência em um dado 
Sistema de revisão por pares na ciência: o caso de revistas científicas do

momento histórico e circunscrito em um espaço em que as variadas relações se conformam (Bufrem, 2014).

Diante do exposto, chega-se às seguintes questões de pesquisa: a) como se configura o sistema de revisão pelos pares nas revistas científicas por áreas do conhecimento no Brasil, na Espanha e no México?; b) qual o sistema de revisão pelos pares preferencial dos periódicos científicos dessas áreas em cada país?; e c) as áreas do conhecimento em cada país se comportam de forma semelhante no que se refere à adoção do sistema de avaliação da literatura periódica?

Para responder tais questionamentos, o objetivo central do trabalho é examinar os sistemas de avaliação pelos pares adotados pelas principais revistas brasileiras, mexicanas e espanholas das várias áreas do conhecimento com o objetivo de identificar diferenças e semelhanças em suas práticas de avaliação.

O entendimento que norteia o estudo é de que, por proximidade de objetos e objetivos, as áreas do conhecimento aglutinam campos e domínios específicos com múltiplos fins. A tônica da aproximação aqui admitida se dá pelo compartilhamento de ideias, conceitos, atividades, instrumentos de controle e divulgação, entre outros, de forma espontânea ou induzida (Souza, 2004). Logo, visualizar às formas de avaliação que governam a prática científica das áreas permite compreender como funciona a lógica de produção do conhecimento por meio das revistas científicas.

\section{A revisão por pares: aspectos gerais}

Um pesquisador que precisa ter seus trabalhos publicados deve submeter sua produção à avaliação de outros pesquisadores que, como ele, é também conhecedor (ainda que não necessariamente em profundidade) do objeto pesquisado. Desde o Século XVII, este mecanismo de avaliação é utilizado nas publicações científicas e recebe o nome de revisão por pares (Brown, 2006; Cassella, 2010; Jenal et alli, 2012; Ranalli, 2011). Depois de realizar seu trabalho de investigação, sozinho ou em equipe, empírico ou teórico, "os cientistas apresentam suas conclusões de pesquisa a um periódico científico, e este, por sua vez, as envia para serem avaliadas em termos de qualidade, importância e originalidade a peritos qualificados e independentes que estão pesquisando e publicando trabalhos no mesmo campo (pares)" (Brown, 2004, p. ix). 
Segundo o Science Media Centre, em um pequeno guia que traz orientações sobre a revisão por pares, esse processo significa: a) uma forma de controle de qualidade científica; uma forma de autorregulação para a ciência; um processo de verificação, crítica e melhoria da pesquisa. O guia também afirma que "a revisão por pares é onde os cientistas abrem sua investigação ao escrutínio de outros especialistas no campo"(SMC, 2003, p. 1). Para ilustrar como se processa a revisão por pares, traz-se à discussão a Figura 1 que ilustra a trajetória avaliativa nas revistas científicas.

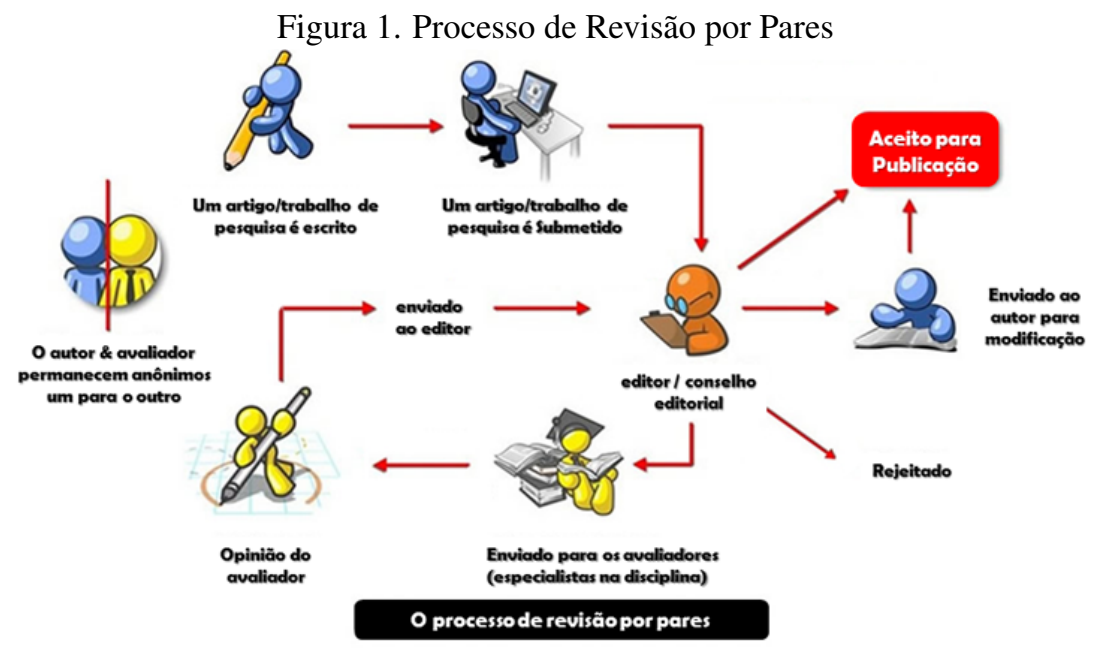

Fonte: www.enago.com.br

O fluxo avaliativo referente ao processo de revisão por pares também é alvo de críticas, mesmo considerando-o como mecanismo de controle da qualidade da produção científica enquanto instância privilegiada da comunicação científica, especialmente em periódicos. As críticas mais recorrentes apontam para a natureza subjetiva desse processo, sua incapacidade de detectar erros, falsificação e plágio; a lentidão e o atraso na publicação do artigo; subjetividade e parcialidade do parecer do revisor e também e possíveis conflitos de interesse nesse processo (Bortomé, 2010; Cassella, 2010).

As críticas empreendidas ao sistema de avaliação são legítimas, mas também não se deve desconsiderar os seus benefícios, sobretudo quando o processo é conduzido por cientistas comprometidos com a ciência. Desta forma, 
Sistema de revisão por pares na ciência: o caso de revistas científicas do

pondera-se: poderia a ciência lograr outra forma de aferir os méritos e a importância do trabalho de seus agentes que não recorrer aos próprios agentes, verdadeiros conhecedores dos protocolos científicos que não estão presentes em outros campos sociais? Para Stumpf (2005), o sistema de revisão pelos pares possui fragilidades de diversas ordens, porém ele é o mais difundido e tradicional. Destaca ainda que as críticas devem ser feitas, mas com apresentação de soluções aos pontos que necessitam de melhorias e aprimoramento.

Um dos pontos cruciais que circunda as formas de revisão por pares recai no anonimato, tanto de autores quanto de revisores. É difícil precisar se os méritos do anonimato superam os deméritos. Segundo Ohler (2010), em periódicos de enfermagem mais de $90 \%$ dos revisores preferem este sistema e acreditam que ele contribui mais para a qualidade do processo. O revisor parece mais interessado no anonimato do que o autor, pois dependendo do resultado da avaliação, o revisor não terá problemas com autor, que não poderá identificá-lo. Mulligan, Hall e Raphael (2013), em uma pesquisa com mais de 4 mil respondentes, identificaram que a modalidade de revisão mais indicada pelos respondentes como eficaz foi o duplo cego (76\%), seguido do simples cego (45\%) e do sistema aberto (20\%).

A base de dados Scopus foi criada em 2004 e tem como um dos critérios para inclusão de revistas científicas que em suas políticas editoriais incluam a revisão por pares na modalidade duplo cego (Rojas V. e Rivera M., 2011). Entretanto, nem todas as bases possuem critérios claros quanto à modalidade de revisão por pares a ser utilizada pelo periódico para que o mesmo faça parte da coleção. Nos critérios para admissão e permanência de periódicos científicos na Coleção SciELO Brasil (2014), por exemplo, não há exigência de que a modalidade seja duplo cego ou qualquer menção ao tipo de revisão a ser praticada pelo periódico.

Por outro lado, o tema do anonimato está ligado também à confiabilidade das informações. Todos os agentes envolvidos no processo precisam manter o sigilo não só das identidades, mas também das informações. Segundo o European Peer Review Guide (2011) da European Science Foundation, pesquisas sobre revisão por pares indicam que a modalidade simples-cego é a mais utilizada na maioria das organizações. No entanto, afirma o documento, em alguns países escandinavos há legislação que exige total transparência na avaliação quando há financiamento público. 


\section{Procedimentos Metodológicos}

Este trabalho é parte de uma pesquisa voltada para a comparação do sistema de avaliação pelos pares em três países, de natureza exploratória, estando este concentrado na modalidade avaliativa em periódicos científicos. Os países escolhidos foram: Brasil, Espanha e México. A seleção das revistas obedeceu aos critérios de qualidade exigidos nos países, com ênfase nas mais qualificadas, tendo em vista que elas atendem a todos os requisitos necessários para serem contempladas nas principais bases e listas de organismos científicos de renome.

Após a seleção dos periódicos, identificaram-se os editores para envio do questionário, composto de onze questões fechadas e uma aberta e elaborado a partir da Escala Visual Analógica (EVA) para dor (Visual Analogue Scale - VAS), muito utilizada na área médica para aferir a intensidade da dor em pacientes atendidos em hospitais, prontos-socorros, etc. (Martinez; Grassi; Marques, 2011). As questões contempladas pelo questionário buscaram verificar as dificuldades enfrentadas pelos editores na realização das tarefas que compõem a gestão de um periódico científico. Entretanto, neste trabalho a questão explorada é aquela que questionava os editores quanto ao tipo de sistema de avaliação praticado pelo periódico no qual era editor. O instrumento foi enviado em dois momentos: a) no período de 16 a 20 de fevereiro de 2015 para editores brasileiros e para metade do universo de editores espanhóis; e b) no período de 27 de maio a $1^{\circ}$ de junho de 2015 para editores mexicanos e a outra metade dos editores espanhóis.

Convém esclarecer que os periódicos foram selecionados a partir das bases e listas científicas de seus respectivos países. O agrupamento dos periódicos nas quatro áreas do conhecimento foi com base na autodeclaração dos editores científicos quando da resposta ao questionário. O número de periódicos e a distribuição em áreas do conhecimento são expressos a seguir.

1. Brasil: 187 periódicos presentes no Sistema Qualis da CAPES no estrato A1 e A2 em pelo menos uma área do conhecimento, assim distribuídos: 67 das Ciências da Vida, 14 das Ciências Puras, 25 das Ciências Sociais e 81 das Humanidades;

2. Espanha: 189 revistas certificas com o selo de qualidade editorial pela lista da Fundación Española para la Ciencia y Tecnología (FECYT), 
Sistema de revisão por pares na ciência: o caso de revistas científicas do

sendo: 11 revistas de Ciências da Vida, 29 das Ciências Puras, 85 das Ciências Sociais e 66 das Humanidades; e

3. México: 137 revistas constantes Índice de Revistas Mexicanas de Investigación Científica y Tecnológica, com a seguinte distinção: 19 de Ciências da Vida, 32 de Ciências Puras, 50 de Ciências Sociais, 32 de Humanidades e 4 consideradas multidisciplinares.

A pesquisa foi desenvolvida em três etapas. Na primeira foi realizado um estudo a partir da literatura sobre o processo de revisão por pares tendo como enfoque sua importância enquanto mecanismo de certificação do conhecimento científico e reprodução de valores e crenças no campo científico. A segunda etapa consistiu na identificação da população-alvo que foi constituída de editores de periódicos científicos de grande prestígio segundo os critérios das agencias de cada país estudado, seguido da elaboração e aplicação do questionário. A terceira etapa consistiu na análise dos dados mediante um tratamento estatístico descritivo com o intuito de confirmar ou não, nas respostas analisadas, aspectos trazidos à luz pela literatura pertinente.

\section{Resultados}

A taxa de retorno dos questionários enviados foi de $21,4 \%$ para a amostra de editores brasileiros, 24,3\% para editores espanhóis e 31,4\% para editores mexicanos, embora tenha havido semelhança no número de respondentes dos três países participantes da pesquisa (Brasil, 42; Espanha, 46; México, 46). Em relação à composição da amostra de editores brasileiros, predominaram editores de Ciências Sociais e no caso espanhol, editores da área de Ciências da Vida. No caso mexicano há certo equilíbrio entre Ciências da Vida e Ciências Sociais de um lado e Ciências Puras e Humanidades de outro.

A modalidade de revisão por pares que prevaleceu na comparação entre as respostas de editores dos três países foi a duplo cego. Editores de revistas espanholas relataram que em $89,1 \%$ dos periódicos a modalidade mais praticada é a duplo cego, enquanto que no Brasil a taxa para essa modalidade é $81 \%$ e no México, $80,4 \%$. A modalidade simples cego prevaleceu em $19 \%$ das respostas de editores brasileiros e em $17,4 \%$ nas respostas de editores mexicanos. Editores espanhóis responderam que o sistema simples cego só é praticado em $8,7 \%$ das revistas. Os dados também revelaram que em periódicos brasileiros 
que compuseram a amostra, o sistema aberto não é praticado. Mesmo para editores espanhóis e mexicanos a taxa de uso do sistema no processo de revisão por pares foi baixa, de $2 \%$ para ambos os países, conforme se observa no Gráfico 01.

Gráfico 1. Modalidade de revisão praticada em periódicos, por país (percentagens)

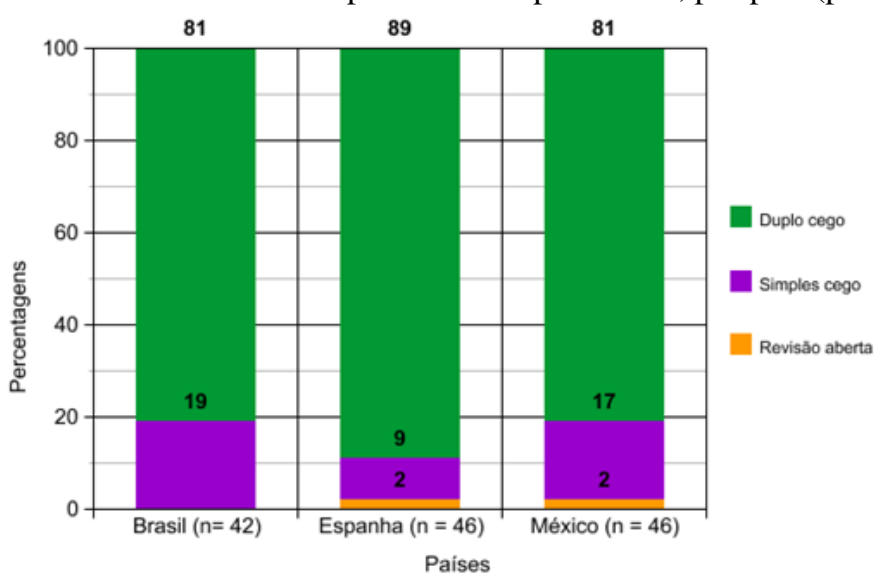

Fonte: dados de pesquisa

A representação acima evidencia a prevalência da modalidade duplo cego praticada pelos periódicos mais importantes nos três países, sendo que na Espanha alcançou $89 \%$ do universo analisado. A modalidade simples cego é pouco utilizado pelas revistas brasileiras, espanholas e mexicanas, com índices de prática entre $9 \%$ à $19 \%$. Chama atenção também que apenas as revistas do Brasil não praticam a revisão aberta em suas avaliações, enquanto que as da Espanha e do México são mais escassas.

O Gráfico 01 sinaliza que as práticas avaliativas das revistas científicas dos três países são semelhantes, tendo em vista os valores informados pelos editores científicos. O cenário apresenta realidades semelhantes no que concerne às atividades editoriais dos periódicos dos três países, mas com sensíveis diferenças e, embora parcial, expressam que o anonimato é a prática avaliativa mais recorrente. Contudo, nota-se que a abertura para a divulgação de revisores e autores poderá ser visualizada em outros contextos e em outros períodos 
Sistema de revisão por pares na ciência: o caso de revistas científicas do Brasil, da Espanha e do México

de tempo. Nesses termos, questiona-se: qual o cenário da revisão pelos pares praticados por esses periódicos em seus países no futuro próximo?

Quanto às áreas do conhecimento e a dimensão das modalidades de revisão por pares, o Gráfico 02 é apresentado a seguir.

Gráfico 2. Áreas do conhecimento e modalidades de revisão por pares (percentagens)

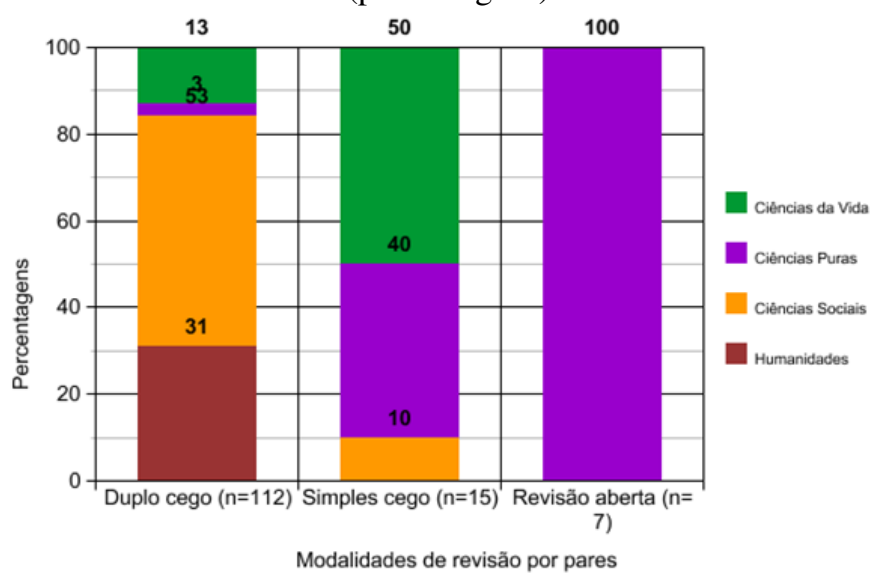

Fonte: dados de pesquisa

O Gráfico 02 ilustra os valores em percentuais da revisão por pares praticada em cada uma das áreas de conhecimento dos periódicos que participaram da pesquisa, com destaque para algumas particularidades:

a) o sistema duplo cego é utilizado por todas as áreas do conhecimento, com predominância nas Ciências Sociais (53\%) e Humanidades (31\%);

b) o sistema simples cego é praticado por três das quatro áreas, sobretudo pelas Ciências da Vida (50\%) e Ciências Puras (40\%); e

c) o sistema de revisão aberta é a modalidade praticada apenas pelas $\mathrm{Ci}$ ências Puras.

A ilustração acima aponta que as revistas da área das Humanidades só utilizam o sistema duplo cego e as Ciências Puras, em sua maioria, a revisão aberta. Verifica-se que, em sua maioria, as revistas das Ciências da Vida se utilizam da revisão simples cego e das Ciências Sociais da revisão duplo 
cego. Percebe-se ainda que os periódicos das Ciências Puras caminham em sentido oposto ao das Humanidades e Ciências Sociais, concentrando-se na divulgação dos envolvidos no processo de avaliação. A configuração do quadro apontado sugerem as seguintes questões:

a) quais as causas que levam os periódicos das Ciências Puras a utilizarem a revisão aberta como modalidade em suas práticas de avaliação?;

b) as justificativas dos periódicos das Ciências Puras são antagônicos aos das Ciências Sociais e Humanidades?; e

c) quais os motivos dos periódicos das Ciências da Vida?

Para discutir sobre as modalidades de revisão por pares praticadas pelos periódicos nos países contemplados pelo estudo, traz-se o Gráfico 03 que apresenta o caso brasileiro.

Gráfico 3. Modalidade de revisão praticada em periódicos brasileiros, por área de conhecimento (percentagens)

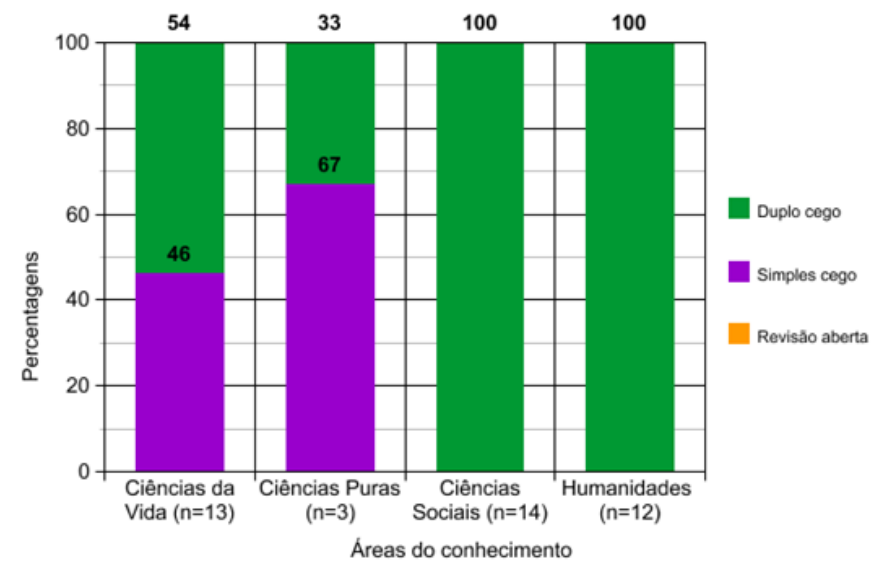

Fonte: dados de pesquisa

A representação gráfica indica que os periódicos brasileiros contemplados neste estudo não praticam a revisão aberta em nenhuma das quatro áreas do conhecimento. Já a revisão duplo cego é a modalidade praticada por todas as áreas, sendo que nas Ciências Sociais e as Humanidades pela totalidade das revistas examinadas. Para as Ciências da Vida, o sistema duplo cego chega 
Sistema de revisão por pares na ciência: o caso de revistas científicas do

a 54\% dos periódicos, destacando sua vitalidade e dividindo espaço com o sistema simples cego, $46 \%$ do total. Por sua vez, a modalidade de revisão duplo cego é menos utilizado pelos periódicos brasileiros das Ciências Puras, com 33\% do total, em detrimento da revisão simples cego com $67 \%$.

O panorama descrito do caso brasileiro aponta que as práticas de avaliação nas revistas científicas estão concentradas no sistema duplo cego, com indícios de abertura expressiva para o simples cego nas Ciências da Vida e Ciências Puras. Por outro lado, as Ciências Sociais e as Humanidades não consideram outra forma de avaliação a não ser o duplo cego, ambas com 100\%. Com isso, questiona-se:

a) quais as razões que levam as revistas brasileiras das Ciências Sociais e das Humanidades a utilizarem o sistema duplo cego como prática de avaliação, em detrimento das outras opções?; e

b) estão as revistas de Ciências da Vida e Ciências Puras caminhando para outras perspectivas de avaliação de originais em que o anonimato não é mais tão importante?

A seguir, apresenta-se o Gráfico 04 que mostra as modalidades de avaliação dos periódicos espanhóis por áreas do conhecimento. 
Gráfico 4. Modalidade de revisão praticada em periódicos espanhóis, por área de conhecimento (percentagens)

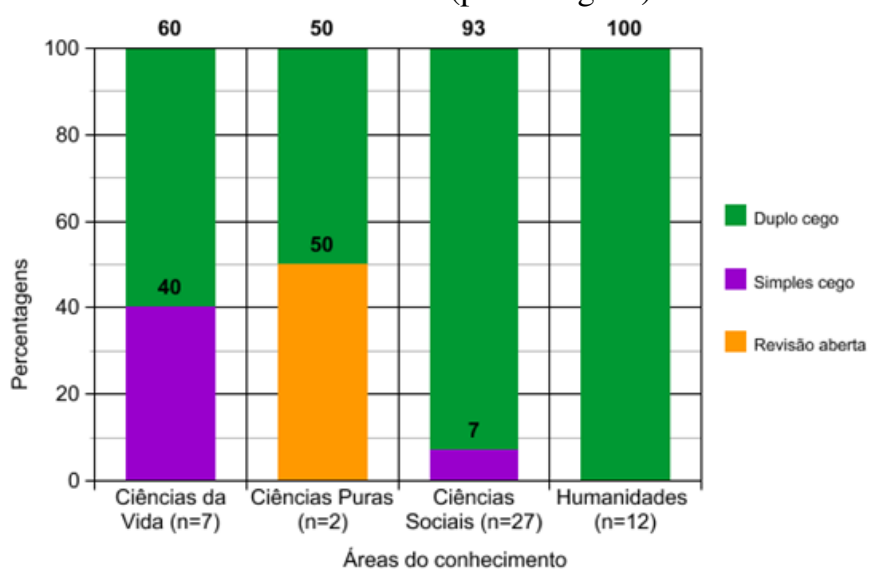

Fonte: dados de pesquisa

A ilustração revela que o sistema duplo cego é a modalidade de avaliação preferida de todas as revistas espanholas nas quatro áreas do conhecimento. O sistema simples cego é contemplado com mais ênfase por periódicos das Ciências da Vida, com $40 \%$ do total, e mais timidamente pelos periódicos das Ciências Sociais, com $8 \%$. Já a revisão aberta é praticada por metade das revistas espanholas das Ciências Puras que compõem o universo estudado.

No caso espanhol, as respostas dos editores de periódicos analisados revelam que as áreas do conhecimento se utilizam apenas de duas formas de avaliação de originais, com exceção das Humanidades, que privilegia o duplo cego. Para as Ciências da Vida e as Ciências Puras, as práticas avaliativas se encontram equilibradas, enquanto que nas Ciências Sociais a distinção entre as duas formas é mais desigual. Do panorama evidenciado, surgem dois questionamentos:

a) quais os motivos que levam os poucos periódicos espanhóis das Ciências Sociais a utilizarem o sistema simples cego como modalidade de avaliação de artigos, tendo em vista que a parte significativa pratica o duplo cego?; 
Sistema de revisão por pares na ciência: o caso de revistas científicas do

b) por que as práticas de avaliação praticadas pelas revistas das Ciências Puras são antagônicas, na medida em que o anonimato é importante para algumas e não para outras?

O Gráfico 05, expresso a seguir, aponta as preferências de avaliação dos periódicos do México nas quatro áreas do conhecimento.

Gráfico 5. Modalidade de revisão por pares praticada em periódicos mexicanos, por área de conhecimento (percentagens)

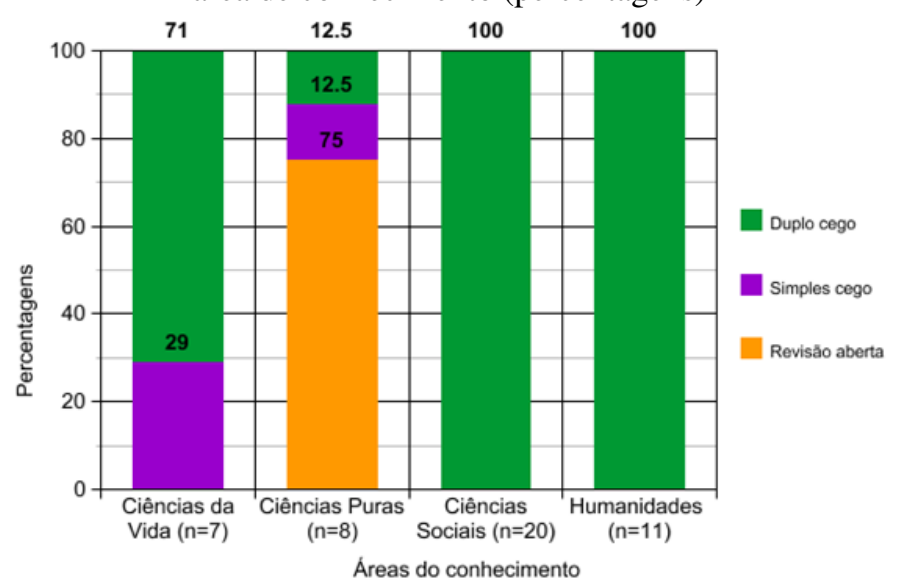

Fonte: dados de pesquisa

O Gráfico 05 sinaliza que os periódicos mexicanos das quatro áreas do conhecimento fazem uso do sistema duplo cego em suas práticas de avaliação, e em números representativos em três áreas. A modalidade simples cego é praticada de forma tímida e por apenas duas áreas do conhecimento: Ciências da Vida e Ciências Puras com 29\% e 12,5\% respectivamente. Menciona-se a exclusividade da prática de avaliação de originais, em que revisores e autores são conhecidos, pelas revistas das Ciências Puras, com 75\% do total da área do conhecimento.

O quadro apresentado acima revela que três áreas do conhecimento não abrem mão do anonimato nas avaliações, sobretudo as Ciências Sociais e as Humanidades, ambas com 100\%; as Ciências da Vida, ainda com práticas de avaliação de simples cego, a modalidade duplo cego é a preferida por mais de $70 \%$ das revistas mexicanas. Cabe registrar também a pluralidade de mo- 
dalidades nas revistas das Ciências Puras do México, que contemplas as três possibilidades, com predominância da revisão aberta. Diante do cenário percebido, surgem as seguintes questões:

a) quais as razões que levam os periódicos do México das Ciências Puras a praticarem a revisão aberta com tanta ênfase?;

b) quais as tendências para os próximos anos quanto à manutenção da modalidade de avaliação para os periódicos mexicanos das Ciências Puras que não praticam a revisão aberta?;

c) os periódicos das Ciências Sociais e das Humanidades do México continuarão a privilegiar o anonimato com forma de revisão por pares?

\section{Considerações finais}

As práticas de avaliação da qualidade do conhecimento científico voltadas às modalidades de revisão por pares em periódicos observadas, neste trabalho, sugerem dois aspectos importantes: a dimensão nacional e o fazer científico das áreas do conhecimento. Embora estejam fortemente relacionados entre si, tais aspectos também se distanciam, pois modos particulares de produção e comunicação da ciência são praticados. Nesse sentido, a revisão por pares que acontece em cada país mostra que o comportamento dos pesquisadores pode estar subordinado tanto à natureza epistemológica da ciência quanto às formas que compreendem a avaliação em periódicos.

A preferência entre o anonimato ou não no processo de avaliação por pares adotado pelos periódicos parece ser o cerne da questão, pois se observou que as áreas tidas como mais flexíveis (soft science) foram aquelas onde esse sistema avaliativo esteve mais presente, mesmo sabendo que o anonimato absoluto pode ser um mito, em algumas circunstâncias de produção e comunicação. Em alguns casos, o estilo, os metadados e a especialidade de um estudo podem relevar facilmente a autoria para o revisor e, dependendo da área do conhecimento, a avaliação pode ser conduzida de muitas formas.

Por outro lado, o anonimato parcial praticado na modalidade simples cego aponta ser um indício de que avaliação da produção científica é utilizada tanto para o reconhecimento dos pares, quanto para a aferição de sua qualidade das contribuições submetidas. Com isso, perpetuam-se os valores estabelecidos em cada campo científico e ainda a reprodução da estrutura que rege a distri- 
Sistema de revisão por pares na ciência: o caso de revistas científicas do

buição de prestígio, moeda fundamental para a consolidação dos cientistas em um determinado campo.

Portanto, afirma-se que os objetivos apresentados foram alcançados, tendo em vista que o panorama proposto foi exibido na perspectiva de um trabalho de natureza exploratória. Entre as principais afirmações sobre os resultados obtidos é de que as formas de avaliação de originais em periódicos científicos costumam variar de área para área de forma mais contundente, enquanto que de país para país de forma sensível e particular. Contudo, em algumas áreas do conhecimento, as práticas de avaliação são bem distintas, trazendo questionamentos para o futuro, sobretudo ao que envolve o anonimato.

\section{Referências}

Botomé, S.P. (2011). Avaliação entre "pares" na ciência e na academia: aspectos clandestinos de um julgamento nem sempre científico, acadêmico ou "de avaliação". Psicologia USP, junho, 22(2): 335-356. Recuperado em 12 de abril de 2015, de http://dx.doi.org

Brown, D. (2006). Scientific communication and the dematerialization of scholarship. Proquest-CSA Discovery Guides. Mar. Recuperado em 14 novembro, 2013, de www.csa.com

Brown, T. (2004). Peer review and the acceptance of new scientific ideas. London: Sense About Science.

Bufrem, L.S. (2014). Faces da produção periódica na Ciência da Informação: o processo de legitimação científica e seus componentes. Informação \& Informação, 19(3): 01-19. Londrina.

Cassella, M. (2010). Social peer-review e scienze umane, ovvero "della qualità nella Repubblica della scienza". JLIS.it, Giugno/June, 1(1): 111-132. Recuperado em 30 janeiro, 2014, de http://dialnet.unirioja.es

Fundación Europea de la Ciencia (2011). European peer review guide integrating policies and practices into coherent procedures. Strasbourg: European Science Foundation. Recuperado em 30 junho 2015, de www.vr.se

Jenal, S.; Vituri, D.W.; Ezaías, G.M.; Silva, L.A. \& Caliri, M.H.L. (2012). O processo de revisão por pares: uma revisão integrativa de literatura. Acta Paulista de Enfermagem, 25(5): 802-808. Recuperado em 16 abril, 2015, de www.scielo.br. 
Martinez, J.E; Grassi, D.C. \& Marques, L.G. (2011). Análise da aplicabilidade de três instrumentos de avaliação de dor em distintas unidades de atendimento: ambulatório, enfermaria e urgência. Revista Brasileira de Reumatologia, 51(4): 304-308. Disponível em: www.scielo.br. Acesso em 09 de maio de 2015.

Mulligan, A.; Hall, L. \& Raphael, E. (2013). Peer Review in a Changing World: An International Study Measuring the Attitudes of Researchers. Journal of the American Society for Information Science and Technology, 64(1): 132-161. Recuperado em 26 de maio de 2015 de http://dx.doi.org.

Ohler, L. (2010). Escrevendo para publicação: questões éticas. Texto \& Contexto Enfermagem, 19(2): 214-216. Recuperado em 10 junho de 2015 de www.redalyc.org

Pavan, C. \& Stumpf, I.R.C. (2009). Avaliação pelos pares nas revistas brasileiras de Ciência da Informação: procedimentos e percepções dos autores. Encontros Bibli, 14(28): 73-92. Florianópolis.

Ranalli, B. (2011). A prehistory of peer review: religious blueprints from the hartlib circle. Spontaneous Generations: A Journal for the History and Philosophy of Science, 5(1): 12-18. Recuperado em 15 de março de 2015 de http://dx.doi.org

Rojas, V.M.A. \& Rivera, M.S. (2011). Guía de Buenas Prácticas para Revistas Académicas de Acceso Abierto. ONG Derechos Digitales. Recuperado em 25 de maio de 2015 de www.derechosdigitales.org

SCIELO BRASIL. (2014). Critérios SciELO Brasil: critérios, política e procedimentos para a admissão e a permanência de periódicos científicos na coleção SciELO Brasil. São Paulo. Versão de setembro de 2014. Recuperado em 1 de julho de 2015 de www.scielo.br

SMC. (2003). Peer review in a nutshell. Recuperado el 30 de 06 de 2015, de Science Media Centre: www.sciencemediacentre.org

Stumpf, I.R. (2005). Avaliação de originais nas revistas científicas: uma trajetória em busca do acerto. In S.M. Ferreira \& M.d. Targino, Preparação de revistas científicas: teoria e prática (pp. 103-120). São Paulo: Reichmann \& Autores.

Souza, R.F. de (2004). Áreas do conhecimento. Datagramazero, 5(2), sem paginação. 